\title{
Alaska's Mineral Industry 2007
}

\section{SpeCIAL Report 62}

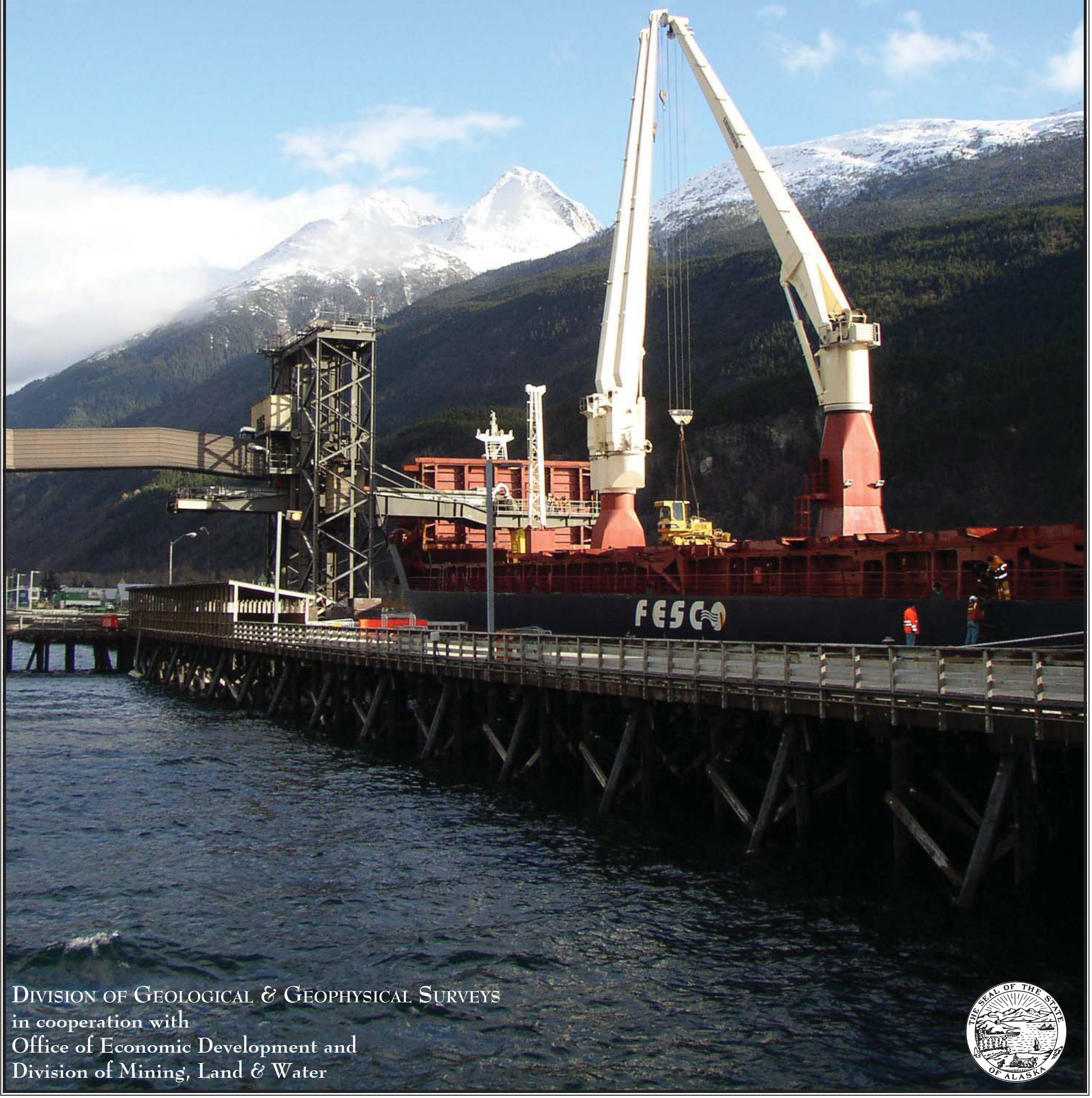


Front cover. Unloading a Cat bulldozer at the Skagway ore terminal. The Alaska Industrial

Development \& Export Authority (AIDEA) and Sherwood Copper Corp. signed a 7-

Sherwood's Minto Mine in the Yukon Territory, Canada. Photo by Chris Nyman, R\&M

Alaska!s Mineral Industry 2007 


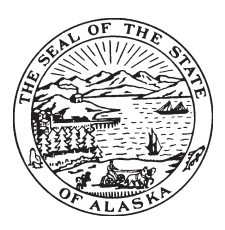

STATE OF ALASKA

Sarah Palin, Governor

DEPARTMENT OF COMMERCE, COMMUNITY \& ECONOMIC DEVELOPMENT

Emil Notti, Commissioner

OFFICE OF ECONOMIC DEVELOPMENT

Joe Austerman, Manager

DEPARTMENT OF NATURAL RESOURCES

Tom Irwin, Commissioner

DIVISION OF GEOLOGICAL \& GEOPHYSICAL SURVEYS

Robert F. Swenson, State Geologist and Director

\section{DIVISION OF MINING, LAND \& WATER \\ Dick Mylius, Director}

DGGS publications may be inspected at the following locations. Address mail orders to the Fairbanks office.

\author{
Alaska Division of Geological \\ \& Geophysical Surveys \\ ATTN: Geologic Communications \\ 3354 College Road \\ Fairbanks, Alaska 99709-3707 \\ Elmer E. Rasmuson Library \\ University of Alaska Fairbanks \\ Fairbanks, Alaska 99775-1005
}

\author{
University of Alaska Anchorage \\ Consortium Library \\ 3211 Providence Drive \\ Anchorage, Alaska 99508
}

ARLIS (Alaska Resource Library
$\quad$ and Information Service)
3211 Providence Drive
Anchorage, Alaska 99508

Alaska State Library

State Office Building, 8th Floor

333 Willoughby Avenue

Juneau, Alaska 99811-0571

This publication, released by the Division of Geological \& Geophysical Surveys (DGGS), was produced and printed in Fairbanks, Alaska, by UAF Printing Services, at a cost of $\$ 4.27$ per copy. Authority to print this and other publications comes from Alaska Statute 41.08.020, which charges DGGS "to determine the potential of Alaskan land for production of metals, minerals, fuels, and geothermal resources; the location and supplies of groundwater and construction materials; the potential geologic hazards to buildings, roads, bridges, and other installations and structures; and . . conduct such other surveys and investigations as will advance knowledge of the geology of Alaska." In addition, Alaska Statute 41.08.030 states, "The state geologist shall print and publish an annual report and such other special and topical reports and maps as may be desirable for the benefit of the state..." 



\section{GOVERNOR'S FOREWORD}

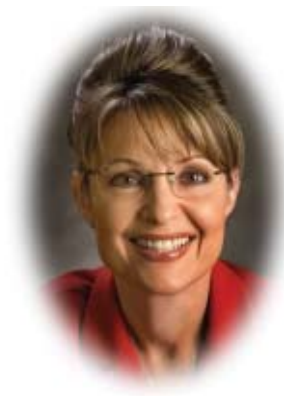

I am honored to present this report detailing the continuing strength of Alaska's mineral industry in 2007. Facts and figures throughout this report tell the story of a healthy, growing, and vital sector of our state's economy. As the world looks to the Arctic regions, Alaska stands as a shining example of a place where responsible natural resource development can be done in an environmentally conscious manner.

Alaska is blessed with a vast array of natural resources, and it is our responsibility to provide responsible stewardship and wise development of these resources for the benefit of the people of our state. As we reach the end of our first half-century of statehood and look eagerly towards the future, it is satisfying to know that we are successfully fulfilling this responsibility.

The total value of the Alaskan mineral industry continues to increase. The value of minerals produced in Alaska increased over the last year by 18 percent to almost $\$ 3.4$ billion. We now have six large producing mines in the state-Greens Creek, Fort Knox, Red Dog, Pogo, Rock Creek, and Usibelli. Numerous small mines throughout the state also contribute to Alaska's economy.

Mining continues to offer Alaskans benefits that come with long-term jobs that pay among the highest average wages in the state. In 2007, mining generated an estimated 3,558 full-time jobs. Many of these employment opportunities occur in rural areas where residents are eager to provide the needed staffing and services. The mineral industry and support industries will continue to generate even more jobs as more prospects are proven viable.

I am proud of the accomplishments of the men and women who make up Alaska's mining community, and of the spirit that makes those accomplishments possible. I wish them continued success as they, and we, look to the future with excitement and confidence.

\section{Governor Sarah Palin}




\section{COMMISSIONER'S FOREWORD}

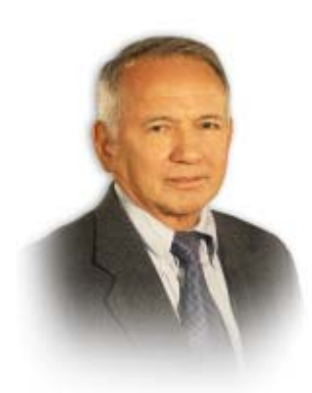

The Department of Commerce, Community \& Economic Development (Commerce) is pleased to participate with the Department of Natural Resources (DNR) to bring you the 27th annual report on Alaska's mineral industry.

This report clearly shows that the Alaska minerals industry continues to mature and expand. The Department of Commerce is proud to contribute to the important industry growth by assisting in the responsible development of Alaska's vast and diverse mineral resources.

In 2007, for the 11th consecutive year, the total value of the industry exceeded $\$ 1$ billion and actually exceeded $\$ 4$ billion, approximately $\$ 475$ million more than in 2006. The state moved from sixth to fifth in ranking among the 50 states for value of non-fuel minerals production. Rising metal prices bode well for the profitability of future and now-producing mines, for moving existing projects forward, and for enticing exploration for new and existing discoveries in the state.

Existing projects provided approximately 3,500 high paying jobs in 2007, about the same as in 2006. Maintaining the employment number in spite of reduced development but increased hard rock mining and exploration indicates a strong minerals industry. Demand for skilled and technical workers exceeded availability. Significant improvements in the industry's value and an increase in job opportunities are expected in future years due to a number of major projects now in progress.

The Pogo Mine continued to improve productivity, but failed to reach full production goals of 340,000 ounces of gold per year. Coeur Alaska continued construction at the Kensington project, but has been unable to settle the tailings disposal issue revolving around using the Lower Slate Lake disposal site; this issue is being heard by the U.S. Supreme Court. In the meantime, Coeur is requesting a permit for disposal of tailings on the Lynn Canal side of the site in paste form. Rock Creek/Big Hurrah continues in the advanced stages of development with initial production expected in late 2008. Nixon Fork produced for a short period during 2007, but shut down due to ore reserve issues. Barrick/NovaGold's advanced stage Donlin Creek gold exploration project continues to move forward with feasibility, advanced ore definition, and engineering.

Other major exploration projects demonstrate the mineral potential and attractiveness of the state to the mining industry. The Pebble Copper project in southwestern Alaska continues to be intensely explored by Northern Dynasty and Anglo American. Copper-gold porphyry projects in southwestern Alaska include Whistler, Kawisgag, Mount Estelle, Pebble South, and Chisna projects. Intrusion-related gold exploration continued in the Interior at Livengood, Liberty Bell, Gold Hill, Kisa, and Vinasale. High-grade gold deposit exploration was conducted at Terra, Pogo, Lucky Shot, Golden Summit, Rob, Maple Leaf, Ganes Creek, Blue Quartz, and Little Squaw projects. Base-metal exploration was conducted at Red Dog, Lik-Su, Arctic, and Sun SEDEX and volcanogenic massive sulfide (VMS) properties in the Brooks Range and at the Palmer and Niblack properties in southeastern Alaska, and at the LWM project in the eastern Interior region. Platinum and associated metals exploration continued at the MAN project in the Alaska Range and in the Goodnews Bay area. The statewide minerals industry is forecast to grow significantly although commodity prices will influence intensity of effort.

The Palin Administration continues to provide a favorable business climate for statewide mineral industry growth. Alaska's taxation and fee structure is fair and stable, and the regulatory structure is progressive. State government's direct support through incentives, information, and technical support provides a valuable asset for companies active in Alaska mineral development.

\section{Emil Notti, Commissioner, Department of Commerce, Community and Economic Development}




\section{COMMISSIONER'S FOREWORD}

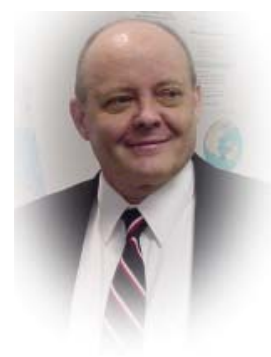

2007 was another successful year for Alaska’s mining industry, eclipsing highs measured in 2006. As this report shows, the mining industry continues to be an increasingly important sector of Alaska's economy, and it is doing so in an environmentally responsible manner. In 2007, the value of Alaska's mineral industry reached an all-time high, and exploration expenditures increased by 84 percent. In addition to providing 3,558 full-time jobs, the mineral industry was the largest tax payer in the City and Borough of Juneau, the Fairbanks North Star Borough, the Denali Borough, and the Northwest Arctic Borough.

This increase in mining activity comes with an increased public awareness of the industry, and increased scrutiny. I am proud of the environmental record of Alaska’s mining industry, and I believe we have a sound permitting and regulatory system. Nevertheless, our process continues to be challenged, and wherever appropriate, we will continue to work to improve that process. In the past year, state and federal regulators have made numerous presentations at various public forums throughout the state to inform the public about mining and mine permitting, as well as to hear the public's concerns. This effort will continue and I urge all Alaskans to attend these presentations and to educate themselves about mining and our regulatory process. I want all Alaskans to have confidence that we can responsibly permit and regulate mines.

Soaring energy costs are stressing our citizens, especially the residents of rural Alaska. People are leaving the villages and moving to the cities because they can’t afford to heat their homes. Governor Palin is working on several fronts to address this dire situation, and we cannot overlook the huge potential that mineral development has for helping some rural regions of our state. Mining holds great promise for alleviating many of the economic problems in rural Alaska. Large mines have the potential to lower energy costs for nearby communities. Also, high-paying mining jobs can give residents the economic means to better afford fuel and electricity, and to support their families.

I'd like to highlight some of the mining industry and DNR's accomplishments in 2007. Permits were issued for the new Walter Valley heap leach, a major expansion at the Fort Knox mine; a facility that is projected to add 10 years to the life of the mine. Construction continued at the Kensington mine near Juneau and the Rock Creek Mine near Nome. The state has been actively following federal wetlands litigation regarding the Kensington mine that is now before the U.S. Supreme Court, as it may have broader implications for development throughout Alaska.

Major exploration efforts continued at Donlin Creek and the Pebble project. DNR issued permits for some 70 exploration projects, including advanced exploration projects such as Niblack on Prince of Wales Island. Other activities at DNR included permitting for ongoing major mine projects, monitoring and inspection of operating and closed mines, and the remediation of abandoned mine lands from an era before the current permitting and regulatory regime. In 2007, applications for small placer gold mining operations and the maintenance of mining records were at all-time highs.

In 2007, the DNR Division of Geological \& Geophysical Surveys (DGGS) continued its active data acquisition programs to gather and disseminate new geological and geophysical information. The staff at DGGS work hard to provide unbiased scientific information on natural hazards, energy resources, and mineral occurrences that are essential for responsible development and maintaining a healthy economy. This report provides valuable information to Alaskans about our mining industry and is a tool we can all use as we continue to improve our stewardship of Alaska's natural resources.

\section{Tom Irwin, Commissioner, Department of Natural Resources}





\section{EXECUTIVE SUMMARY}

Alaska's Mineral Industry 2007 is the 27th annual report produced in a cooperative venture between the Division of Geological \& Geophysical Surveys (DGGS) and the Division of Mining, Land \& Water in the Department of Natural Resources, and the Office of Economic Development in the Department of Commerce, Community and Economic Development (Commerce). This report and data supersede previously published DGGS Information Circular 57.

The total value of Alaska’s mineral industry in 2007 set a new record of approximately $\$ 4$ billion, a 13.3 percent rise over the 2006 level. The total value is determined by combining exploration and development expenditures with production value. The new record was the 12th straight year in which the total value exceeded $\$ 1$ billion.

The mineral industry paid a total of \$142.4 million in royalty and tax payments to the State of Alaska and Alaska municipalities in 2007. These payments represented a reduction of almost \$30 million from the 2006 payments, but were still the second highest on record. Mining license taxes dropped by 31.2 percent from 2006 values. Mining companies were the largest taxpayers in the City and Borough of Juneau and the Fairbanks North Star, Denali, and Northwest Arctic boroughs, contributing total payments of almost \$15.8 million. Teck Alaska Inc., operator of the Red Dog Mine, paid the Alaska Industrial Development \& Export Authority annual user fees of \$17.7 million for use of the Stateowned DeLong Mountain Regional Transportation System. Teck Cominco Ltd. paid NANA Regional Corp. \$58.1 million in FY07 as a net smelter royalty, nearly double the FY 2006 payment of \$29.7 million.

Minerals industry employment was 3,558 full-time-equivalent jobs in 2007, an increase of 35 jobs above the 2006 estimate, and the highest number of jobs over the past decade. The exploration, development, and production sectors accounted for 499, 735, and 2,324 jobs, respectively. Alaskan metal miners made an average weekly wage of \$1,578 during 2007.

Exploration expenditures in Alaska during 2007 reached \$329.1 million, 84 percent higher than the \$178.9 million spent in 2006. At least 33 projects had exploration expenditures of $\$ 1$ million or more and 85 projects had exploration expenditures in excess of $\$ 100,000$. These projects were dotted across Alaska, with more than $\$ 180$ million spent in southwestern Alaska. Companies explored for a wide variety of mineral deposits, and copper-gold porphyry systems (grouped with polymetallic deposits) were the major exploration target in 2007. Advanced exploration projects included Barrick Gold Corp.-NovaGold Resources Inc.-Calista Corp.'s 33.7-million-ounce Donlin Creek intrusionhosted gold project and Northern Dynasty Minerals Ltd.'s Pebble copper-gold porphyry project, both in southwestern Alaska. The Pebble project, with newly announced measured mineral resources of 74 billion pounds of copper, 87 million ounces of gold, and 5.2 billion pounds of molybdenum, was the largest Alaska mineral exploration project in 2007. New mineral resources were announced at Geoinformatic Exploration Inc.'s Whistler project, International Tower Hill Mines Ltd.’s LMS and Terra projects, NovaGold Resources Inc.'s Ambler project, and Barrick Gold Corp. and NovaGold Resources Inc.'s Donlin Creek project.

Mineral development projects were spread statewide, with total expenditures of $\$ 318.8$ million, a 35.7 percent decrease from the record 2006 value of $\$ 495.7$ million. Development continued at the Rock Creek project near Nome. Construction was completed at the Mystery Creek project at Nixon Fork and operation was commissioned in the first quarter. Significant expenditures were noted at Red Dog Mine, Fort Knox Mine, the Chuitna Coal project, Greens Creek Mine, and the Kensington project.

Mineral production value of $\$ 3.367$ billion eclipsed all previous years on record, with metals accounting for 95 percent of the value. Production volumes were up for all commodities except coal and rock. Continued strong metal prices also contributed to record production values for Alaska's minerals. Values of production, in decreasing order, were from Red Dog Mine (70.1 percent); Greens Creek Mine (11.8 percent); Fort Knox Mine (7.0 percent); Pogo Mine (5.5 percent); rock, sand, and gravel operations (3.0 percent); coal and peat (1.3 percent); and placer gold operations (1.1 percent). Zinc accounted for 60.8 percent of the total mineral production, followed by gold (15.2 percent), lead (11.6 percent), silver (8.0 percent), rock, sand, and gravel (3.0 percent), coal and peat (1.4 percent); and copper (0.01 percent).

Alaska's mineral exports topped \$1.3 billion in 2007, a 10 percent increase from 2006 and a new record. Zinc ore was the highest value commodity exported from the state. 
Hard-rock (lode) gold production increased from 509,747 ounces in 2006 to 673,084 ounces in 2007. The increase in hard-rock production primarily reflects a higher output from Pogo Mine and some production from Nixon Fork Mine. Placer gold production decreased from 60,382 ounces in 2006 to 53,849 ounces in 2007. Rapidly increasing operating costs have had a negative effect on operations. However, recreational placer mining continues to increase with the improved gold prices, with 1,882 ounces produced in 2007 compared to 1,133 ounces for 2006.

Sales of sand and gravel in 2007 totaled 14.2 million tons, up slightly from 14.0 million tons in 2006. Rock production was 2.2 million tons, down from 2.4 million tons in 2006.

The Alaska Railroad earned \$16.3 million in net income during 2007 from total revenue of \$169.3 million. Freight accounted for $\$ 91.8$ million (54 percent) of the total, with revenue from mineral products (coal, sand, and gravel) amounting to \$14.8 million, down 16.6 percent from 2006 levels.

Drilling was conducted during all phases of mining (exploration, development, and production) on various projects across Alaska during the year. Total drill footage of 1,168,704 feet easily exceeded the 2006 total of 835,795 feet and set a new record. Drilling totals for 2007 are 830,478 feet of core drilling, 268,112 feet of reverse-circulation drilling, 50,539 feet of core and reverse-circulation drilling on coal operations, and 19,575 feet of placer auger/churn drilling. Major drilling programs were conducted in most areas of the state. Barrick Gold had the largest drill program in Alaska with more than 230,000 feet of core drilling on the Donlin Creek property.

Alaska Division of Geological \& Geophysical Surveys (DGGS) mapped and sampled in the northeastern Fairbanks mining district and along part of the Alaska Highway portion of the proposed gas pipeline corridor between Delta Junction and Dot Lake.

The State of Alaska, through DGGS, funded and acquired airborne magnetic and electromagnetic geophysical surveys for 180 square miles of the 708-square-mile Styx River survey area in the northeastern Lime Hills and northwestern Tyonek quadrangles. DGGS also released airborne magnetic and electromagnetic geophysical survey data for 613 square miles of the eastern Bonnifield district. DGGS acquired additional airborne magnetic and electromagnetic geophysical data, with funding from the U.S. Bureau of Land Management, for a 250-square-mile area of the western Fortymile mining district.

Sherwood Copper Corp. signed an agreement with Alaska Industrial Development \& Export Authority (AIDEA) to use the Skagway ore terminal for copper-gold ore concentrates from its Minto Mine in the Yukon Territory, Canada. The ore terminal began receiving truckloads of high-grade concentrates in July.

Beginning in 2007, mining licenses were issued by the Alaska Department of Revenue (DOR) instead of the Alaska Department of Natural Resources (DNR). The DNR Water Section began requiring a temporary water permit use for drilling in 2007.

The Ninth U.S. Circuit Court of Appeals ruled in 2007 that the Kensington project wastewater discharge permit issued by U.S. Army Corps of Engineers violated the federal Clean Water Act. The tailings permit, as well as a permit to build a marine terminal to service the mine, was to be vacated. The case will likely be petitioned to the U.S. Supreme Court.

Funding for the U.S. Bureau of Land Management's (BLM) Alaska Minerals Program was not included in the BLM budget for 2008. 


\section{CONTENTS}

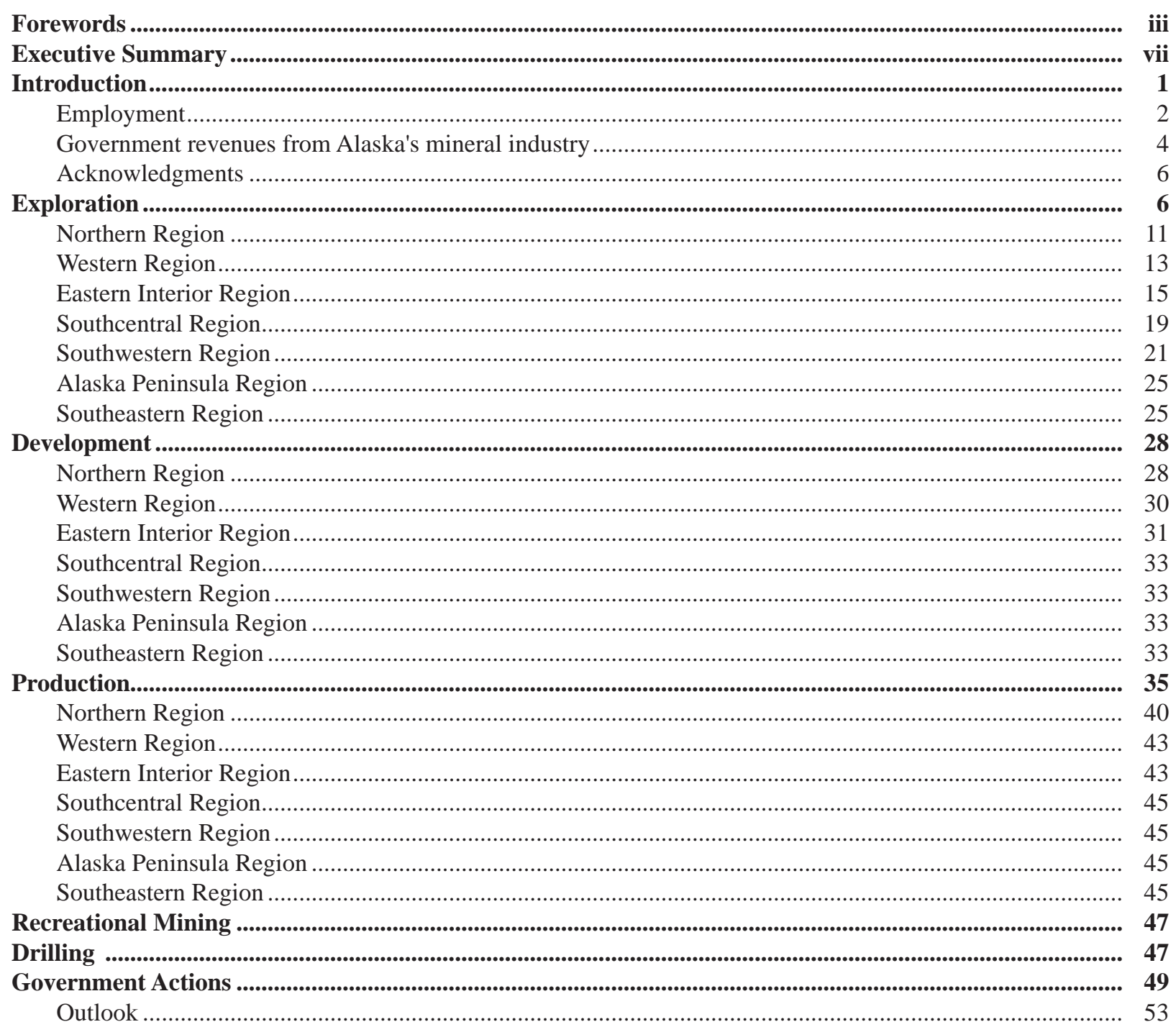

Appendixes
A. New claims staked in Alaska, 2003-2007
B. Prospecting sites in Alaska, 2001-2007.
C. Selected significant mineral deposits and mineral districts in Alaska .................................................. 59
D. Companies and individuals reported to be producing metal in Alaska, 2007 ......................................... 69
E. State and federal agencies and private interest groups involved in mineral development activities

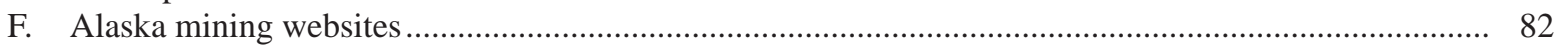
G. U.S. customary units and metric units conversion chart ..................................................................... 84

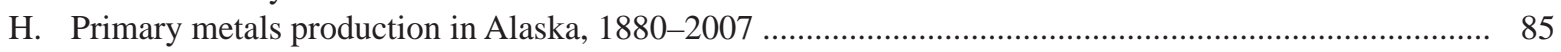
I. Production of industrial minerals, coal, and other commodities in Alaska, 1880-2007 ......................... 88 


\section{CONTENTS}

\section{Figures}

1. Map showing regions of mineral activity in Alaska as described in this report ....................................... 1

2. Graph showing exploration and development expenditures and the value of production of Alaska’s mineral industry, 1981-2007

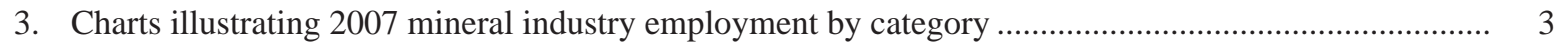

4. Graph showing total mineral industry employment, 1998-2007 .................................................. 4

5. Graph showing mining industry revenue to State of Alaska and muncipalities from 1999-2007 ........... 6

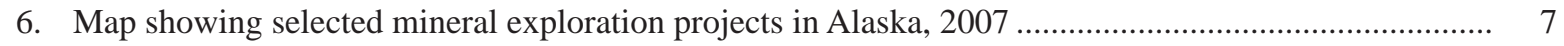

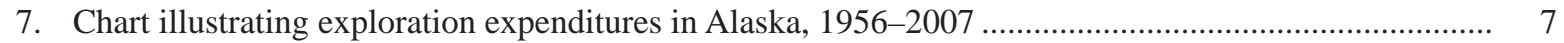

8. Chart illustrating 2007 exploration expenditures by commodity ...................................................... 8

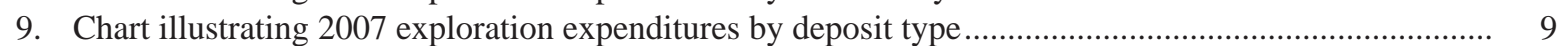

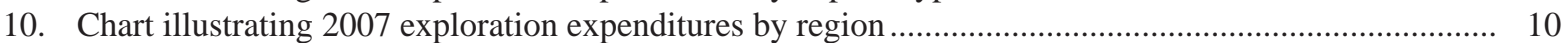

11. Photo showing a BHP Billiton Ltd. geologist examining coal seam near Point Lay ........................... 13

12. Photo showing a helicopter used on Full Metal Minerals Ltd.'s 40 Mile project ................................ 17

13. Photo showing Rolling Stone Inc.'s sand and gravel operation ....................................................... 19

14. Photo showing drilling on precipitous terrain at Gold Crest Mines Inc.'s Kisa property ....................... 23

15. Photo showing Spencer Lyman collecting dirt and gravel to pan from a prospect hole near Crooked Creek.

16. Photo showing road building and access construction for underground exploration at the Niblack VMS property

17. Photo showing Precision GeoSurveys Inc. conducting a helicopter-borne radiometric and magnetic survey in rugged terrain at Ucore Uranium Inc. and Landmark Minerals Inc.’s Bokan Mountain uranium-rare-earth-element property.

18. Map showing selected mineral development projects in Alaska, 2007 ............................................. 30

19. Aerial view of construction at NovaGold Resources Inc.'s Rock Creek gold mine and mill complex .... 31

20. Photo showing Coeur Alaska Inc.'s mill complex at the Kensington gold property............................. 34

21. Graph showing sand and gravel production in Alaska, 1950-2007 ............................................... 36

22. Graph showing amount and value of gold production in Alaska, 1880-2007 .................................. 36

23. Graph showing coal production in Alaska, 1915-2007, including exports to Korea............................ 36

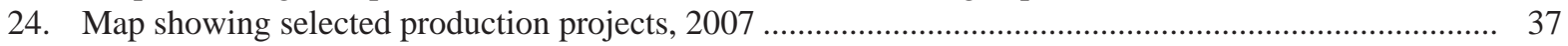

25. Chart illustrating Alaska mineral production value by commodity .............................................. 37

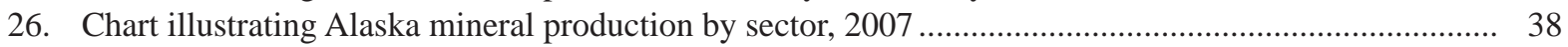

27. Graph showing Alaska international mineral exports, 1996-2007 ............................................... 41

28. Photo showing a recreational placer miner feeding a high-banker sluice box on Chicken Creek ........... 47

29. Photo showing lode drilling conducted on Little Squaw Gold Mining Co.'s Chandalar property

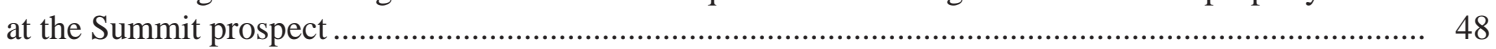

30. Photo showing geologists Melanie Werdon and Diana Solie discussing strategy while near Horn Mountain on the Macomb Plateau as part of the DGGS geologic studies for the Alaska Highway Corridor Project. 


\section{CONTENTS}

Tables

1. Total value of the mineral industry in Alaska by year.............................................................................. 2

2. Estimated Alaska mine employment, 1998-2007 .............................................................................. 3

3. Revenues paid to the State of Alaska and municipalities by Alaska's mineral industry, 2002-2007 ....... 5

4. Reported exploration expenditures in Alaska by commodity, 1981-2007 .............................................. 8

5. Reported exploration expenditures and employment in Alaska, 2007 .................................................... 9

6. Summary of claim activity by acres, 1991-2007 ….............................................................................. 10

7. International Tower Hill Mines (Talon Gold) 2007 significant drill results at the Livengood property ... 16

8. Reported mineral development expenditures and employment in Alaska by commodity and

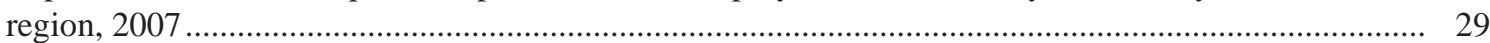

9. Reported mineral development expenditures in Alaska by commodity, 1982-2007 .............................. 29

10. Gold reserves and resources at Rock Creek, Big Hurrah, and various holdings at Nome ....................... 32

11. Estimated mineral production in Alaska, 2005-2007........................................................................... 35

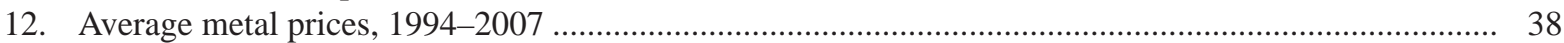

13. Reported refined gold production, number of operators, and industry employment, 2005-2007............. 39

14. Production for selected Alaska placer gold mines, 2000-2007 ............................................................. 39

15. Reported sand and gravel production and industry employment in Alaska by region, 2007 ................... 40

16. Reported rock production and industry employment in Alaska by region, 2007 ................................... 40

17. Alaska international mineral exports ................................................................................................... 41

18. Reserves and resources by category at the Red Dog Mine.................................................................... 41

19. Red Dog Mine production statistics, 1989-2007 ......................................................................... 42

20. Fort Knox Mine production statistics, 1996-2007 ......................................................................... 44

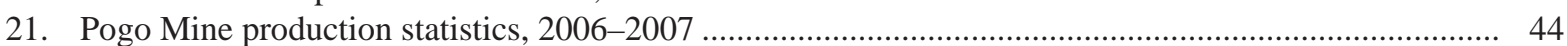

22. Greens Creek Mine production statistics, 1989-2007 .......................................................................... 46

23. Reserves and resources by category at the Greens Creek Mine ........................................................ 46

24. Companies reporting significant drilling programs in Alaska, 2007 ...................................................... 48

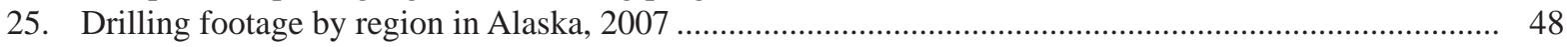

26. Drilling footage reported in Alaska, 1982-2007 .................................................................................. 49

27. Detailed state airborne geophysical surveys and follow-up geologic ground-truth mapping ................... 51

28. Detailed federally funded airborne geophysical survey work contracted by DGGS .............................. 52 



\section{Alaska's Mineral Industry 2007 \\ D.J. Szumigala ${ }^{1}$, R.A. Hughes ${ }^{2}$, and L.A. Harbo ${ }^{2}$}

\section{INTRODUCTION}

Alaska's mineral industry continued its robust growth from 2006 through 2007 primarily due to continued strong metal prices. Mineral production from Alaska's existing mines remained strong, but rising costs and labor shortages are continued concerns. Two new lode mines began production in 2007, and two gold development projects may begin production in 2008 . Exploration activities for a wide variety of commodities continued across all regions of Alaska and new discoveries were announced.

The total value of Alaska's mineral industry in 2007 set a new record of approximately $\$ 4$ billion. The total value is determined as a combination of exploration and development expenditures and production value. This total value, even though it is a combination of expenses and receipts, is an effective way of tracking the annual strength of the mineral industry. Table 1 shows the estimated annual value of the mineral industry in Alaska between 1981 and 2007, as divided between exploration and development investments, and the gross value of the mineral products. The Alaska mineral industry's total value increased 13.6 percent from the 2006 value of $\$ 3.53$ billion. The year 2007 was the twelfth consecutive year with a total value above $\$ 1$ billion, the sixth consecutive with production value above \$1 billion, and the first year with production value above $\$ 3$ billion. This increased production value moved Alaska to fifth place in production value among the states, according to the U.S. Geological Survey. Exploration expenditures above $\$ 300$ million also set new records in 2007, and it was the third consecutive year with exploration expenditures of more than $\$ 100$ million. Development expenditures dropped from the record value set in 2006 , but still added a fourth consecutive year of expenditures exceeding \$200 million.

Figure 1 shows the regions of the state that are used in this report. Table 1 and figure 2 show the estimated value of the mineral industry in Alaska per year between 1981 and 2007, as divided between exploration and development investments, and the gross value of mineral products. Company information is used to define the exploration and development parameters. Average metal prices are calculated from the daily London PM closing price for gold, and from the average weekly spot price on the London Metal Exchange for the other metals. It is important to note that these prices are used to calculate the value of metals produced in the state, but do not take into account the costs of mining or transportation, or smelter charges and penalties. Coal prices are estimated from average coal prices for similar grade material around the Pacific Rim. Industrial material prices are based on regional rates provided by some operators.

Please note that the formatting and presentation of data in some tables has changed compared to previous editions of this report, reflecting changes in data collected and accounting practices by the mining industry. Whenever possible, the authors have worked to maintain consistency of data for seamless year-to-year comparisons. Most changes are noted in footnotes in the affected tables.

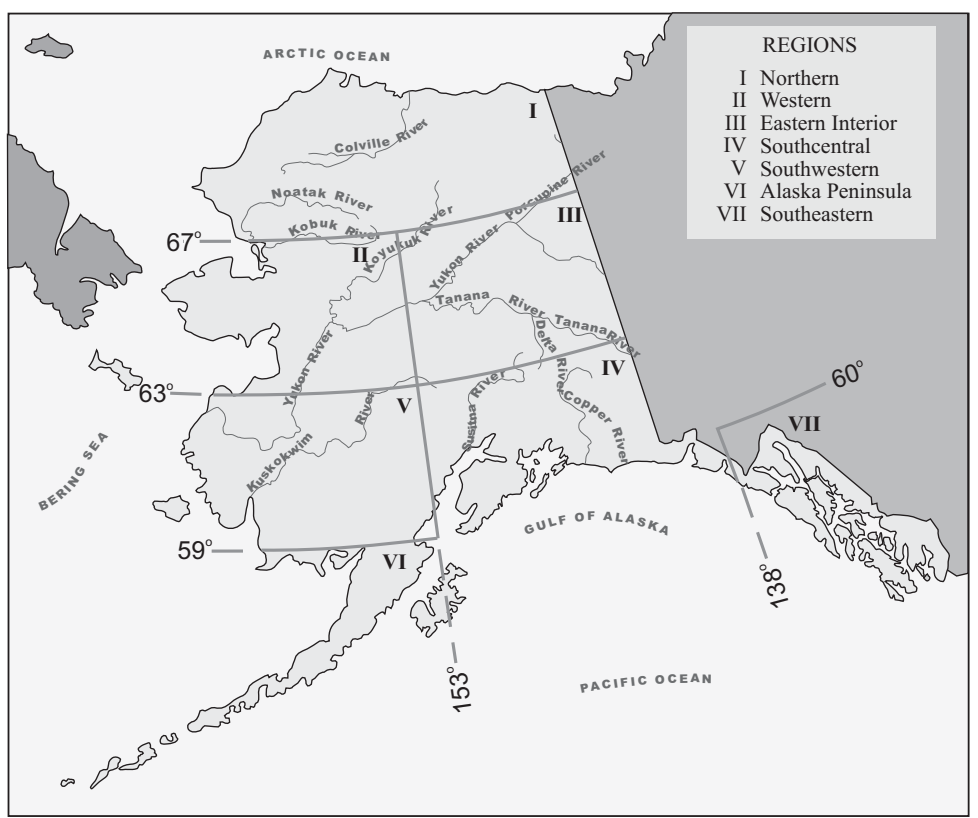

Figure 1. Regions of mineral activity as described in this report.

${ }^{1}$ Alaska Division of Geological \& Geophysical Surveys, 3354 College Rd., Fairbanks, Alaska 99709-3707.

${ }^{2}$ Alaska Department of Commerce, Community \& Economic Development, Office of Economic Development, 211 Cushman St., Fairbanks, Alaska 99701. 
This summary of Alaska's mineral industry activity for 2007 is the 27th in the series of annual reports, and is made possible by information provided through press releases, annual reports, phone interviews, and replies to questionnaires mailed by the Alaska Division of Geological \& Geophysical Surveys (DGGS). This report is part of a cooperative venture between DGGS and the Division of Mining, Land \& Water (DMLW) in the Department of Natural Resources (DNR) and the Office of Economic Development in the Department of Commerce, Community and Economic Development (Commerce). Commerce provides the funding to print the report. Information in this report supersedes data previously published in DGGS Information Circular 57.

\section{EMPLOYMENT}

Figure 3 displays employment within various segments of Alaska's mineral industry. Table 2 lists estimated Alaska mineral industry employment over the past nine years and figure 4 shows the trends in that employment over the same period. Total minerals industry employment in 2007 is estimated to be 3,558 full-time-equivalent jobs, an increase of 35 jobs from the estimated 2006 total of 3,523 jobs. As expected, the number of jobs in the development sector decreased significantly following completion of initial construction of the Pogo gold mine. It is expected that the number of jobs in the development sector will continue to decline for 2008 because the development phases of the Rock Creek and Kensington projects are nearly complete. The significant decrease in employment in the sand and gravel and rock production sectors is believed to be a mix of a slight decrease in employment and a lack of employment information. The steady rise in exploration expenditures from 2003 through 2007 is reflected in the steady increase in exploration employment for that period. The number of jobs in the lode gold production sector will continue to increase as the Rock Creek Mine, and possibly the Kensington Mine, begins
Table 1. Total value of the mineral industry in Alaska by year (in millions of dollars U.S.)

\begin{tabular}{lrrrr}
\hline Year & $\begin{array}{c}\text { Exploration } \\
\text { (expenditure) }\end{array}$ & $\begin{array}{r}\text { Development } \\
\text { (expenditure) }\end{array}$ & $\begin{array}{c}\text { Production } \\
\text { (value) }\end{array}$ & $\begin{array}{c}\text { Total } \\
\text { (calculated) }\end{array}$ \\
\hline 1981 & $\$ 76.3$ & $\$ 24.7$ & $\$ 188.6$ & $\$ 289.6$ \\
1982 & 45.6 & 41.6 & 196.4 & 283.6 \\
1983 & 34.1 & 27.9 & 212.4 & 274.4 \\
1984 & 22.3 & 53.4 & 199.4 & 275.1 \\
1985 & 9.2 & 34.1 & 226.6 & 269.9 \\
1986 & 8.9 & 24.3 & 198.5 & 231.7 \\
1987 & 15.7 & 100.3 & 202.4 & 318.4 \\
1988 & 45.5 & 275.0 & 232.2 & 552.7 \\
1989 & 47.8 & 134.3 & 277.0 & 459.1 \\
1990 & 63.3 & 14.3 & 533.0 & 610.6 \\
1991 & 39.9 & 25.6 & 546.5 & 612.0 \\
1992 & 30.2 & 29.6 & 560.8 & 620.6 \\
1993 & 30.3 & 27.7 & 448.7 & 506.7 \\
1994 & 31.1 & 45.0 & 507.5 & 583.6 \\
1995 & 34.3 & 148.6 & 537.2 & 720.1 \\
1996 & 44.7 & 394.0 & 590.4 & $1,029.1$ \\
1997 & 57.8 & 168.4 & 936.2 & $1,162.4$ \\
1998 & 57.3 & 55.4 & 921.2 & $1,033.9$ \\
1999 & 52.3 & 33.8 & $1,032.9$ & $1,119.0$ \\
2000 & 34.9 & 141.7 & $1,106.4$ & $1,283.0$ \\
2001 & 23.8 & 81.2 & 917.3 & $1,022.3$ \\
2002 & 26.5 & 34.0 & $1,012.8$ & $1,073.3$ \\
2003 & 27.6 & 39.1 & $1,000.7$ & $1,067.4$ \\
2004 & 70.8 & 209.1 & $1,338.7$ & $1,618.6$ \\
2005 & 103.9 & 347.9 & $1,401.6$ & $1,853.4$ \\
2006 & 178.9 & 495.7 & $2,858.2$ & $3,532.8$ \\
2007 & 329.1 & 318.8 & $3,367.0$ & $4,014.9$ \\
\hline TOTAL & $\$ 1,542.1$ & $\$ 3,325.5$ & $\$ 21,550.6$ & $\$ 26,418.2$
\end{tabular}

Source: Alaska's Mineral Industry reports published annually by DGGS/Commerce.

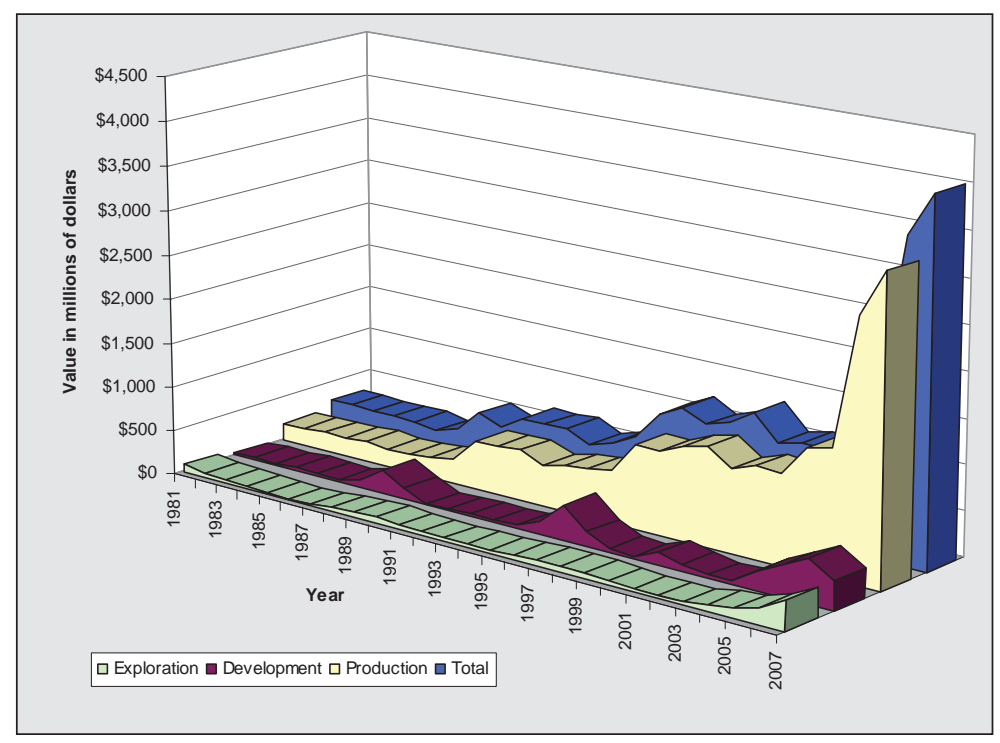

Figure 2. Alaska’s mineral industry total value, 1981-2007. 
Table 2. Estimated Alaska mine employment, 1999-2007ª

\begin{tabular}{|c|c|c|c|c|c|c|c|c|c|}
\hline & 1999 & 2000 & 2001 & 2002 & 2003 & 2004 & 2005 & 2006 & 2007 \\
\hline \multicolumn{10}{|l|}{ Gold/silver mining } \\
\hline Placer & 591 & 470 & 176 & 148 & 82 & 64 & 86 & 242 & 208 \\
\hline Lode & 296 & 274 & 337 & 413 & 325 & 433 & 411 & 704 & 808 \\
\hline Polymetallic mining & 275 & 275 & 275 & 262 & 295 & 265 & 250 & 245 & 276 \\
\hline Base metals mining & 549 & 556 & 559 & 580 & 388 & 508 & 449 & 457 & 457 \\
\hline Recreational mining & 240 & 250 & 210 & 180 & 175 & 175 & 175 & 45 & 54 \\
\hline Sand and gravel & 590 & 603 & 556 & 702 & 349 & 567 & 400 & 337 & 284 \\
\hline Rock & 128 & 150 & 137 & 177 & 35 & 475 & 148 & 104 & 124 \\
\hline Coal & 121 & 121 & 121 & 100 & 65 & 90 & 95 & 95 & 102 \\
\hline Peat $^{b}$ & 38 & 36 & 32 & 21 & 20 & 4 & 6 & 11 & 11 \\
\hline $\begin{array}{l}\text { Tin, jade, soapstone, } \\
\text { ceramics, platinum }\end{array}$ & 20 & 20 & 20 & 20 & 20 & -- & -- & -- & - - \\
\hline Mineral development & 135 & 345 & 333 & 135 & 64 & 283 & 498 & 848 & 735 \\
\hline Mineral exploration & 183 & 83 & 79 & 86 & 88 & 184 & 303 & 435 & 499 \\
\hline TOTAL & 3,166 & 3,183 & 2,835 & 2,824 & 1,906 & 3,048 & 2,821 & 3,523 & 3,558 \\
\hline
\end{tabular}

${ }^{a}$ Reported man-days are calculated on a 260-day work year to obtain average annual employment unless actual average annual unemployment numbers are provided.

${ }^{b}$ This figure does not include all of the man-days associated with peat operations; most of those man-days are included in sand and gravel numbers.

- - = Not reported.

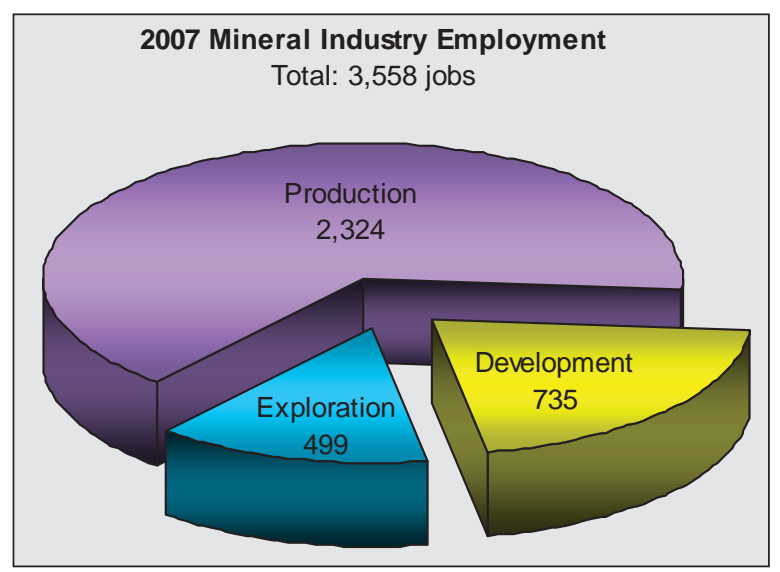

Figure 3. 2007 mineral industry employment in Alaska by category.

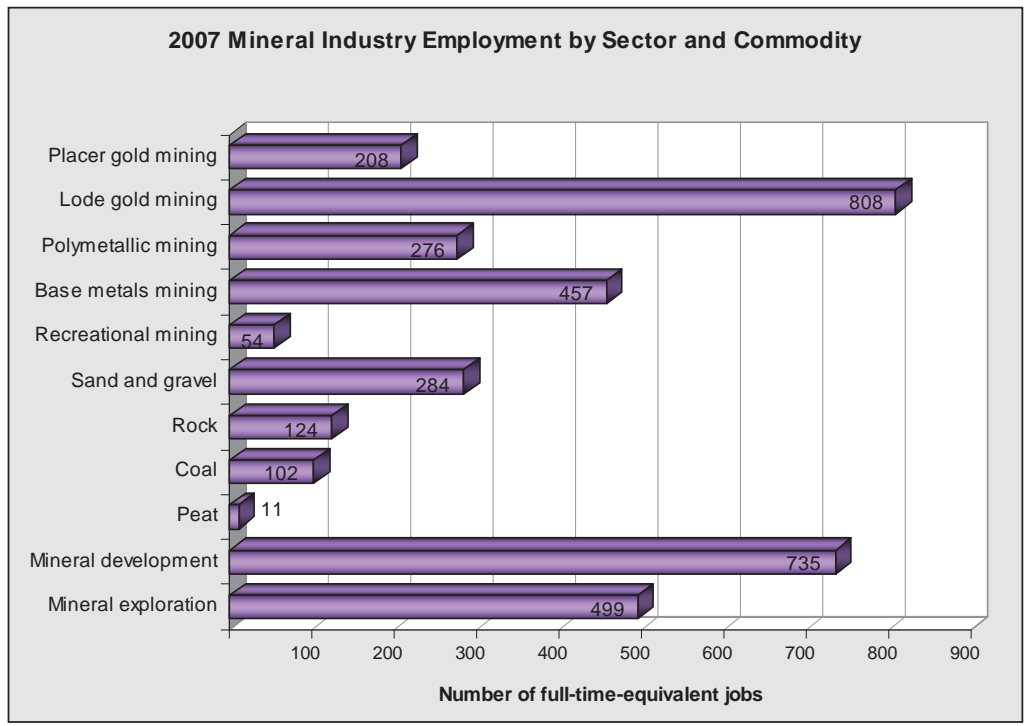


full commercial production in 2008. Higher gold prices may also spur more placer gold mining and employment, but higher fuel and energy prices, along with increased costs of other commodities, have dampened positive reactions to high metal prices.

The average weekly wage for mining in Alaska during 2007 was $\$ 1,578$, according to the Alaska Department of Labor \& Workforce Development (DLWD). They report that the average employment in mining was 1,850 jobs during the first and second quarters of 2007. The average weekly wage for metal mining in Alaska during 2007 was $\$ 1,611$, according to the DLWD. They also report that the average employment during the first and second quarters of 2007 was 1,636 in metal mining, 100 in coal mining, 140 in nonmetallic mineral mining and quarrying, and 8,413 in support activities for mining. Nonmetallic mineral product manufacturing provided 327 jobs, cement and concrete manufacturing provided an average of 316 jobs during 2007, glass manufacturing provided two jobs, primary metal manufacturing provided 17 jobs, and other nonmetallic mineral product manufacturing provided an average of 11 jobs. Metal and mineral merchant wholesalers provided an average of 110 jobs during the first two quarters of 2007. Please note that the Labor \& Workforce Development statistics are collected using different methods than the employment figures collected for this report; thus there is no direct correlation between the two sets of employment figures.

\section{GOVERNMENT REVENUES FROM ALASKA'S MINERAL INDUSTRY}

The State of Alaska mining laws grant the holder of a mining claim exclusive right to the locatable minerals in the ground covered by that mining claim. State mining claims have recording, rental, and other fees associated with them. Mining claim location certificates and recording fees must be recorded in the recording district office in which the claim is located within 45 days of the posting date. Recording fees change from time to time and the recording office should be contacted for the correct fee; recording fees are also posted at the following web site address: www.dnr.state.ak.us/ssd/recoff/fees.cfm. Rental fees under regulation 11 AAC 86.215 will either be $\$ 25$ (quarter-quarter-section location or 40 acres) or $\$ 100$ (quarter section location or 160 acres), and must be paid according to the instructions on the back of the certificate form. The first rental payment covers the period from the date of posting the claim to the following September 1 st.

Upon prospecting, the discovery of a locatable mineral, and the staking of mineral location, annual labor must be performed on the location each year in the further development of the locatable mineral so that it can

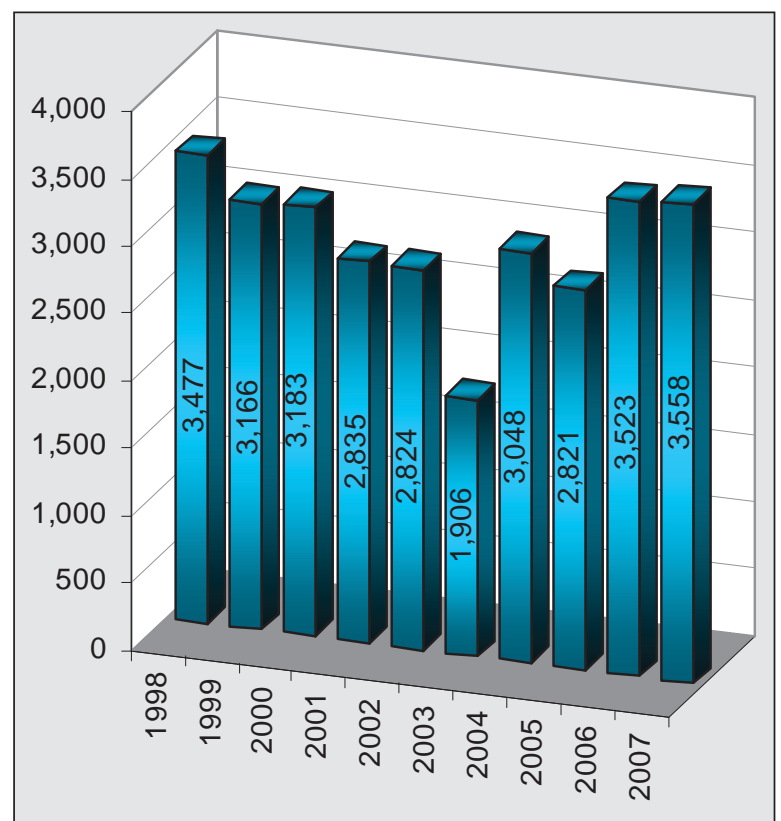

Figure 4. Total mineral industry employment in Alaska from 1998 to 2007.

be mined. The minimum amount of labor that must be performed is dependent upon the size of the location. For traditional or quarter-quarter-section meridian-townshiprange-section-corner (MTRSC) locations, a minimum of $\$ 100$ worth of work per year is necessary. For quartersection MTRSC locations, a minimum of $\$ 400$ worth of work per year is necessary. The holder of a mining claim, leasehold location, or mining lease may instead make a cash payment to the State equal to the value of labor required ( $\$ 100$ or $\$ 400$ per claim).

In 1989, the Alaska State Legislature enacted a new production royalty law, Alaska Statute 38.05.212, which requires holders of state mining locations to pay a production royalty on all revenues received from minerals produced on state land. The production royalty requirement applies to all revenues received from minerals produced from a state mining claim or mining lease during each calendar year. Payment of royalty is in exchange for and to preserve the right to extract and possess the minerals produced. The production royalty is 3 percent of net income as determined under the Mining License Tax Law AS 43.65, and regulation 15 AAC 65. Department of Natural Resources regulations 11 AAC $86.760-796$ spell out the production royalty requirements.

The State of Alaska also receives revenue from material sales from state-owned land. Materials include sand, gravel, riprap, rock, limestone, slate, peat, and any other substances from the ground that are not applied 
for through the location system for mining claims (for example, gold, silver, and other metals), or leasing (for example, energy minerals such as coal, oil, and gas). Materials are measured and sold in cubic yards. The price charged for materials depends on the type, or size, of sale, but prices are based on a competitive or fair market sales price of material in the area. The DNR information office should be contacted for further information.

The mineral industry paid a total of $\$ 142.4$ million to the State of Alaska and Alaska municipalities in 2007 (table 3). These payments decreased by almost $\$ 30$ million from the \$172.3 million collected in 2006 . Although the industry reported an overall record value and record gross production value in 2007 , revenue

Table 3. Revenues paid to the state of Alaska and municipalities by Alaska's mineral Industry, 2002-2007

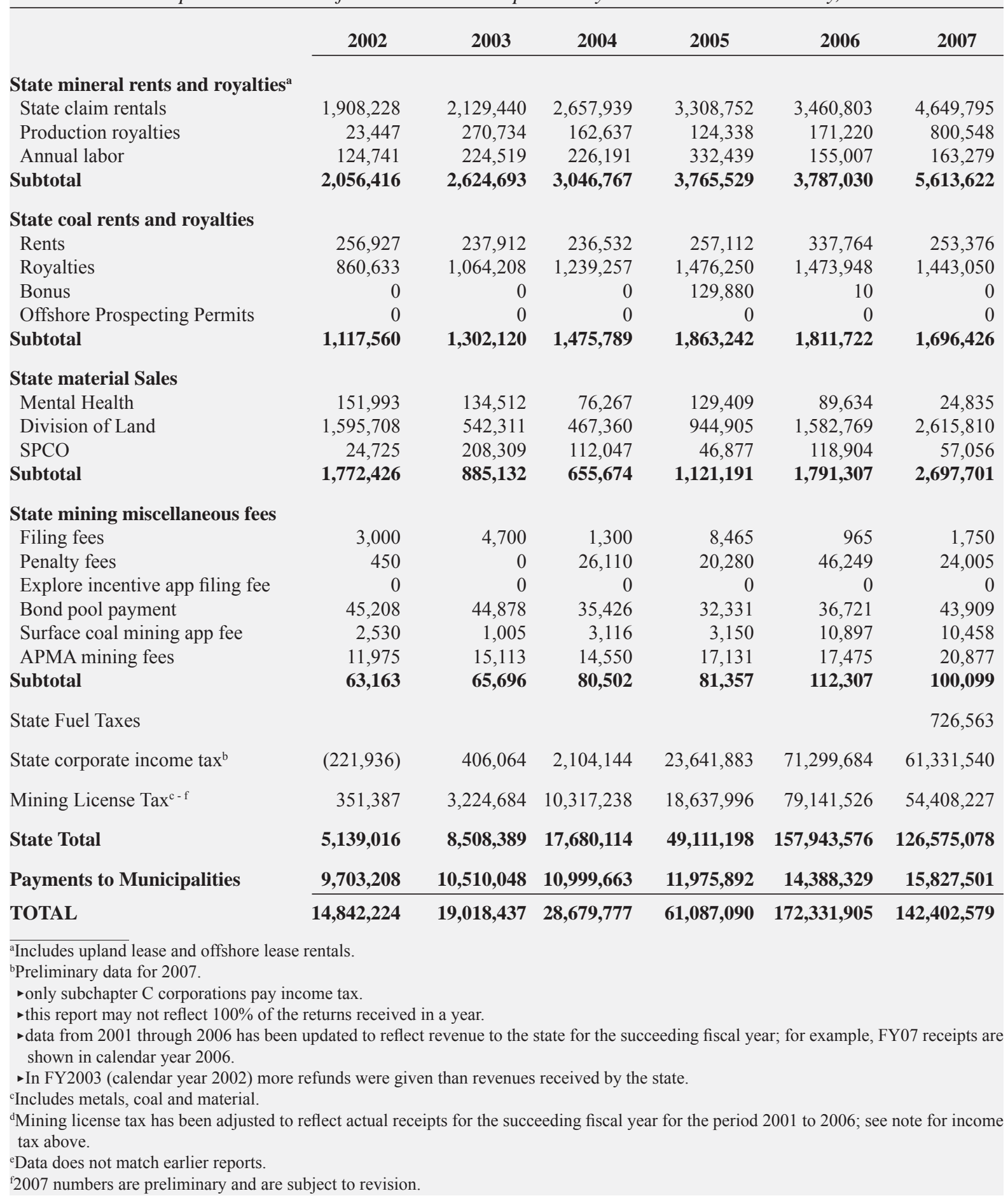


returned to government was lower due to increased operating costs more than offsetting improved commodity prices. Mining license taxes decreased by 31.2 percent from 2006 values, following reduced profitability at all mines. Mining companies were the largest taxpayers in the City and Borough of Juneau and the Fairbanks North Star, Denali, and Northwest Arctic boroughs, with total payments of almost \$15.8 million. Teck Pogo Inc. also paid the City of Delta Junction $\$ 500,000$ as part of a payment in lieu of taxes (PILT) agreement in 2007. Teck Alaska Inc., operator of the Red Dog Mine, paid the Alaska Industrial Development \& Export Authority (AIDEA) annual user fees of $\$ 17.7$ million for use of the State-owned road and port, the DeLong Mountain Regional Transportation System. The AIDEA payments are not included in the fees reported in table 3. Teck Cominco Ltd. paid NANA Regional Corp. \$58.1 million in FY07, ending September 30, 2008, as a net smelter royalty. This was an increase of 95.8 percent over the payment of \$29.7 million for FY 2006.

Revenue to the State of Alaska from mineral-indus-

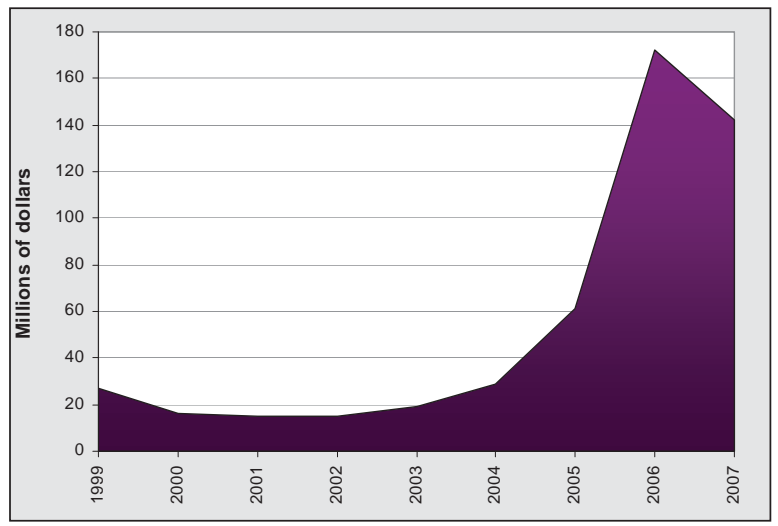

try-specific fees, rent, sales, and royalties from 1999 to 2007 are shown in figure 5. Revenue has increased an average of 1,000 percent in the past 4 years (2004-2007) compared to the average revenue from 1990 to 2003.

\section{ACKNOWLEDGMENTS}

This report on the Alaska mineral industry is intended to provide current, accurate, and technically reliable information. The authors wish to thank all companies, agencies, and individuals that responded to the questionnaires or phone calls and provided information about their activities and operations. Without their voluntary and timely information this report would not be possible. DGGS mailed and emailed more than 700 questionnaires in December 2007 and continued sending additional questionnaires through 2008. We received 166 responses and followed questionnaire requests with phone calls and other means of contact. Dave Szumigala (DGGS) and Rich Hughes (Commerce) prepared the body of the text, tables, graphic illustrations, and appendices with information supplied by many individuals and with the assistance of staff from other agencies. Some photos and images used in this report were provided by members of the public and these contributions are greatly appreciated. Where appropriate, these people have been acknowledged in the text. Information and text previously compiled for DGGS Information Circular 57 were used extensively.

The cover design is by Joni Robinson. Paula Davis (DGGS) edited the final version, and Joni Robinson completed the layout and design. Commerce's Office of Economic Development paid printing costs.

Figure 5. Mining industry revenue to State of Alaska and municipalities from 1999 to 2007.

\section{EXPLORATION}

Exploration expenditures in Alaska during 2007 were more than $\$ 329.1$ million, 84 percent higher than the $\$ 178.9$ million spent in 2006 . Figure 6 shows the location of the most significant exploration projects in Alaska during the year. At least 85 exploration projects in Alaska spent more than $\$ 100,000$ each in 2007 and 33 of those exploration projects spent more than $\$ 1$ million each. Total drill footage of $1,168,704$ feet easily exceeded the 2006 total of 835,795 feet.

Increased exploration expenditures in Alaska mirror increased worldwide mineral exploration budgets. The increases in worldwide exploration expenditures resulted from a combination of increased spending by major mining companies, a significant reduction in the nega- tive influence of industry consolidation from peak years 2000 and 2001, and higher spending by junior mining companies in response to stronger gold and base-metal prices. As in years past, most exploration funds $(>80$ percent) were from Canadian sources.

Figure 7 shows a graph of mineral exploration expenditures in Alaska from 1956 to 2007. Exploration expenditures per year are shown with raw (not adjusted for inflation) and adjusted values (inflation adjusted to 2007 dollars). Exploration expenditures over the last several years has exceeded any previous era of mineral exploration in Alaska over the past 50 years. Companies explored for a wide variety of mineral deposits in Alaska during 2007. Table 4 lists exploration expenditures by 


\section{Northern Region}

1. Red Dog Mine-Teck Cominco Alaska Inc.

2. Lik-Su-Zazu Metals Corp.

3. Ambler mineral belt

a. Ambler Project-NovaGold Resources Inc.

b. Sun-Andover Ventures Inc.

4. Nolan Creek Mine-Silverado Gold Mines Ltd.

5. Western Arctic Coal-BHP Billiton Ltd.

6. Little Squaw Mine-Little Squaw Gold Mining Co.

7. Baird Mountain Project-NovaGold Resources Inc.

\section{Western Region}

8. Rock Creek, Big Hurrah- NovaGold Resources Inc.

9. Boulder Creek-Triex Minerals Corp./Full Metal Minerals Ltd.

10. Kugruk - NovaGold Resources Inc.

11. Nixon Fork Mine-St. Andrew Goldfields Ltd.

12. Ganes Creek-Great Basin Gold Ltd.

III Eastern Interior Region

13. Livengood-International Tower Hill Mines Ltd.

14. Fairbanks District

a. Fort Knox, Gil \& District-Kinross Gold Inc.

b. Golden Summit-Freegold Ventures Ltd.

15. Pogo-Goodpaster mining district

a. Pogo-Teck Cominco Alaska Inc.

b. LMS - International Tower Hill Mines Ltd.

c. Maple Leaf, California North-Rubicon Minerals Corp./Evanachan Ltd./Rimfire Minerals Corp.

d. Mon-Pathfinder Mineral Services

16. Fortymile - Full Metal Minerals Ltd.

17. Gold Hill-Max Resource Corp.

\section{Southcentral Region}

18. Whistler-Geoinformatics Exploration Inc.

19. MAN-Pure Nickel Inc.

20. Anchor Point-Hemis Corp.

21. Lucky Shot-Full Metal Minerals Ltd.

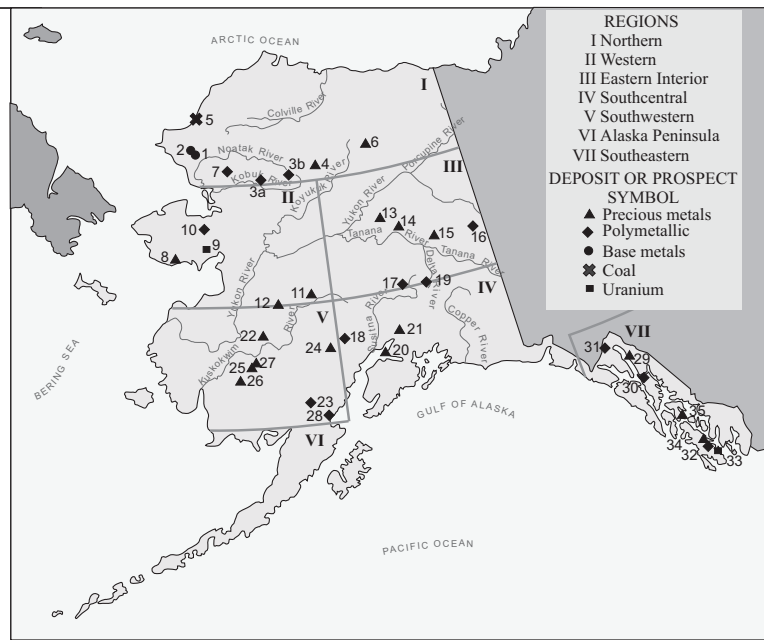

V Southwestern Region

22. Donlin Creek-Donlin Creek JV

23. Pebble-Northern Dynasty Minerals Ltd./Anglo American PLC

24. Terra - International Tower Hill Mines Ltd.

25. Tintina Gold-NovaGold Resources Inc.

26. Kisa-Gold Crest Mines Inc.

27. Buckstock Mountains - Gold Crest Mines Inc.

28. Bristol Bay-Alix Resources Corp./Andover Ventures Inc.

VI Alaska Peninsula Region

VII Southeastern Region

29. Kensington, Jualin - Coeur Alaska Inc.

30. Greens Creek Mine-Kennecott Minerals Co./ Hecla Mining Co.

31. Palmer-Constantine Metal Resources Ltd.

32. Niblack-Niblack Mining Corp.

33. Bokan Mountain-Ucore Uranium Inc./Landmark Minerals Inc.

34. CJ-Altair Ventures Inc./ Full Metal Minerals Ltd.

35. Woewodski Island-Bravo Ventures/Olympic Resources Group LLC

Figure 6 (above). Selected exploration projects in Alaska, 2007.

Figure 7 (right). Alaska mineral exploration expenditures, 1956-2007. Inflation adjusted to 2007 dollars.

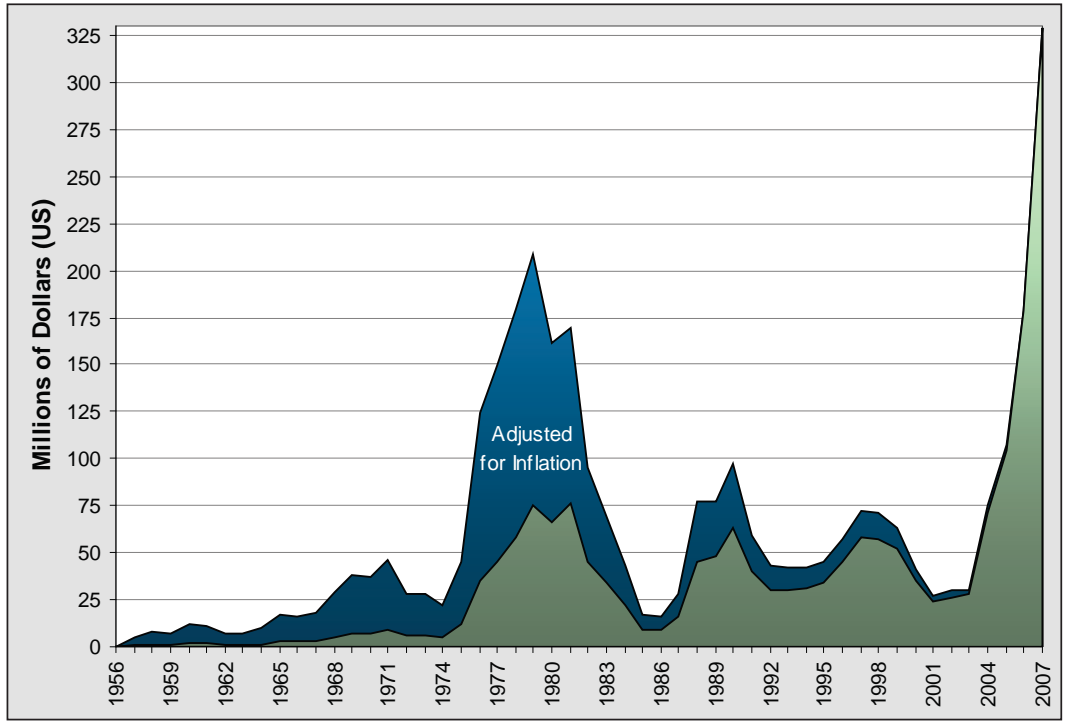


commodity and figure 8 shows the data graphically. Record exploration expenditures were set for base-metal, polymetallic, and precious-metal deposits in 2007. Gold, grouped with other precious metals, remained a major exploration commodity, but exploration expenditures for deposits with a mixed group of metals (polymetallic) was also very strong. Platinum-group-element exploration expenditures in 2007 were slightly above the average expenditures from 2001 to 2006. Figure 9 shows 2007 Alaska exploration expenditures by deposit type. Copper-gold porphyry systems (grouped with polymetallic deposits in table 4) were the major exploration target in 2007 , with $\$ 102.9$ million spent. More than $\$ 87.8$ million was spent on intrusion-related gold deposits and more than $\$ 61.7$ million was spent on various gold-quartz

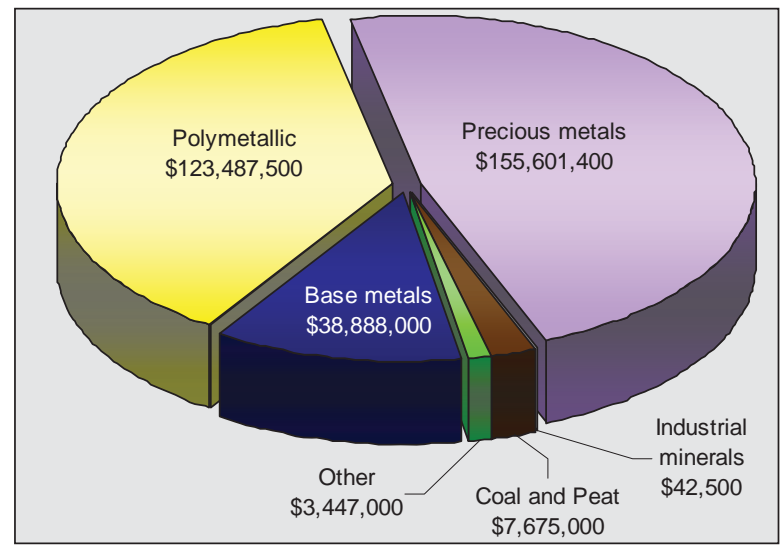

Figure 8. Exploration expenditures in Alaska in 2007 by commodity.

Table 4. Reported exploration expenditures in Alaska by commodity, 1981-2007

\begin{tabular}{|c|c|c|c|c|c|c|c|}
\hline & $\begin{array}{c}\text { Base } \\
\text { metals }\end{array}$ & Polymetallic $^{\mathrm{a}}$ & $\begin{array}{c}\text { Precious } \\
\text { metals }^{b}\end{array}$ & $\begin{array}{c}\text { Industrial } \\
\text { minerals }\end{array}$ & $\begin{array}{c}\text { Coal } \\
\text { and peat }\end{array}$ & Other ${ }^{c}$ & Total \\
\hline 1981 & $\$ 28,262,200$ & N/A & $\$ 35,273,200$ & $\$ 10,300,000$ & $\$ 2,341,000$ & $\$ 127,000$ & $\$ 76,303,400$ \\
\hline 1982 & $31,757,900$ & N/A & $10,944,100$ & - - & $2,900,000$ & 15,300 & $45,617,300$ \\
\hline 1983 & $9,758,760$ & $\mathrm{~N} / \mathrm{A}$ & $20,897,555$ & $2,068,300$ & $1,338,454$ & 70,000 & $34,133,069$ \\
\hline 1984 & $4,720,596$ & N/A & $14,948,554$ & 270,000 & $2,065,000$ & 279,500 & $22,283,650$ \\
\hline 1985 & $2,397,600$ & N/A & $6,482,400$ & - - & 270,000 & -- & $9,150,000$ \\
\hline 1986 & $1,847,660$ & $\mathrm{~N} / \mathrm{A}$ & $6,107,084$ & 170,000 & 790,000 & - - & $8,914,744$ \\
\hline 1987 & $2,523,350$ & N/A & $11,743,711$ & 286,000 & $1,150,000$ & 31,000 & $15,734,061$ \\
\hline 1988 & $1,208,000$ & N/A & $41,370,600$ & 160,200 & $2,730,000$ & -- & $45,468,800$ \\
\hline 1989 & $3,503,000$ & N/A & $43,205,300$ & 125,000 & 924,296 & 5,000 & $47,762,596$ \\
\hline 1990 & $5,282,200$ & N/A & $57,185,394$ & 370,000 & 321,000 & 97,000 & $63,255,594$ \\
\hline 1991 & $4,789,500$ & N/A & $34,422,039$ & 92,000 & 603,000 & 2,000 & $39,908,539$ \\
\hline 1992 & $1,116,000$ & $3,560,000$ & $25,083,000$ & 25,000 & 425,000 & - & $30,209,000$ \\
\hline 1993 & 910,000 & $5,676,743$ & $23,382,246$ & 163,500 & - - & 125,000 & $30,257,489$ \\
\hline 1994 & 600,000 & $8,099,054$ & $18,815,560$ & 225,000 & $2,554,000$ & 810,000 & $31,103,614$ \\
\hline 1995 & $2,770,000$ & $10,550,000$ & $20,883,100$ & 100,000 & - - & 3,000 & $34,306,100$ \\
\hline 1996 & $1,100,000$ & $11,983,364$ & $31,238,600$ & 400,000 & - & -- & $44,721,964$ \\
\hline 1997 & $1,700,000$ & $22,347,000$ & $32,960,500$ & 80,000 & 720,000 & - & $57,807,500$ \\
\hline 1998 & $1,000,000$ & $13,727,000$ & $42,441,000$ & 12,000 & 87,000 & - - & $57,267,000$ \\
\hline 1999 & $3,869,000$ & $3,168,000$ & $44,891,000$ & 1,000 & -- & 410,000 & $52,339,000$ \\
\hline 2000 & $8,545,000$ & $3,933,000$ & $21,579,000$ & 58,500 & - & 736,100 & $34,851,600$ \\
\hline 2001 & $4,810,000$ & $1,977,000$ & $15,820,000$ & 50,000 & 10,000 & $1,106,000$ & $23,773,000$ \\
\hline 2002 & $1,700,000$ & $5,162,000$ & $17,342,000$ & 185,000 & -- & $2,113,000$ & $26,502,000$ \\
\hline 2003 & 262,000 & $7,081,000$ & $19,726,000$ & - & W & 533,000 & $27,602,000$ \\
\hline 2004 & $3,100,000$ & $40,237,000$ & $26,954,000$ & 213,000 & 50,000 & 258,000 & $70,812,000$ \\
\hline 2005 & $1,764,000$ & $54,271,000$ & $46,255,000$ & 142,000 & - - & $1,463,000$ & $103,895,000$ \\
\hline 2006 & $5,069,000$ & $81,073,000$ & $89,793,000$ & 20,000 & $2,394,000$ & 580,000 & $178,929,000$ \\
\hline 2007 & $38,888,000$ & $123,487,500$ & $155,601,400$ & 42,500 & $7,675,000$ & $3,447,000$ & $329,141,400$ \\
\hline Total & $\$ 173,253,766$ & $\$ 396,332,661$ & $\$ 915,345,343$ & $\$ 15,559,000$ & $\$ 29,347,750$ & $\$ 12,210,900$ & $\$ 1,542,049,420$ \\
\hline $\begin{array}{l}{ }^{\mathrm{b}} \text { Appro } \\
2003 \text {, } \\
{ }^{2} \text { Includ } \\
\text { N/A = } \\
-- \text { Not }\end{array}$ & $\begin{array}{l}\text { llic deposits cons } \\
\text { nately } \$ 3.0 \mathrm{M} \text { spe } \\
50,000 \text { in } 2002, \$ \\
\text { diamonds and tan } \\
\text { t available. } \\
\text { ported. }\end{array}$ & $\begin{array}{l}\text { on platinum-gro } \\
\text { on in 2001). } \\
\text { um. }\end{array}$ & $\begin{array}{l}y \text { for the first } \\
\text { ement explora }\end{array}$ & $\begin{array}{l}\text { in } 1992 . \\
\text { during } 2007\end{array}$ & $4 \mathrm{M}$ in 2006 , & $M$ in $2005, \$$ & in $2004, \$ 2.4 \mathrm{M}$ in \\
\hline
\end{tabular}


vein deposits. The sharp increase in exploration expenditures for base-metal-rich, polymetallic massive-sulfide deposits was notable, with almost \$59.4 million spent in 2007, compared to $\$ 18.8$ million spent in 2006 and $\$ 10.0$ million spent in 2005 . About $\$ 3$ million was spent on platinum-group-element-nickel-copper ultramafichosted deposits and about $\$ 14.3$ million was spent on uranium, diamond, tin, coal, placer gold, and other deposit types.

Exploration occurred across Alaska, as shown in table 5, but more than $\$ 180$ million (or 55 percent of the exploration funds) were spent in southwestern Alaska (fig. 10). The eastern Interior and northern regions saw a sharp increase in exploration spending compared to 2006. Exploration expenditures dropped sharply in the Alaska Peninsula region during 2007 compared to 2006.
Two advanced exploration projects, Pebble and Donlin Creek, accounted for most of the exploration expenditures and drill footage in 2007. The Pebble copper-gold porphyry project in southwestern Alaska, with resources of 74 billion pounds of copper, 87 million ounces of gold, and 5.2 billion pounds of molybdenum, is a joint-venture project of Northern Dynasty Minerals Ltd. and Anglo American PLC, and was the largest exploration project in 2007. The 33.7-million-ounce Donlin Creek intrusion-hosted gold project in southwestern Alaska is a joint venture of Barrick Gold Corp., NovaGold Resources Inc., and Calista Corp.

Exploration was conducted in Alaska for a wide variety of metals and mineralization styles during 2007. Copper-gold porphyry projects in southwestern Alaska include the Whistler, Kawisgag, Mount Estelle, Pebble
Figure 9. 2007 Alaska exploration expenditures by deposit type.

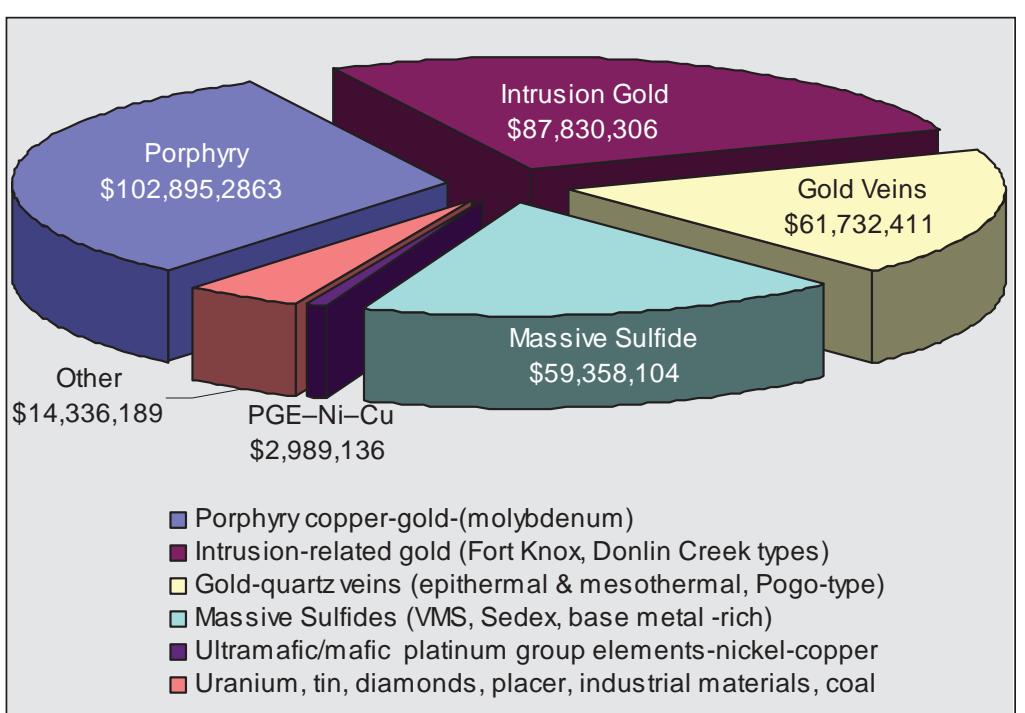

Table 5. Reported exploration expenditures and employment in Alaska, 2007

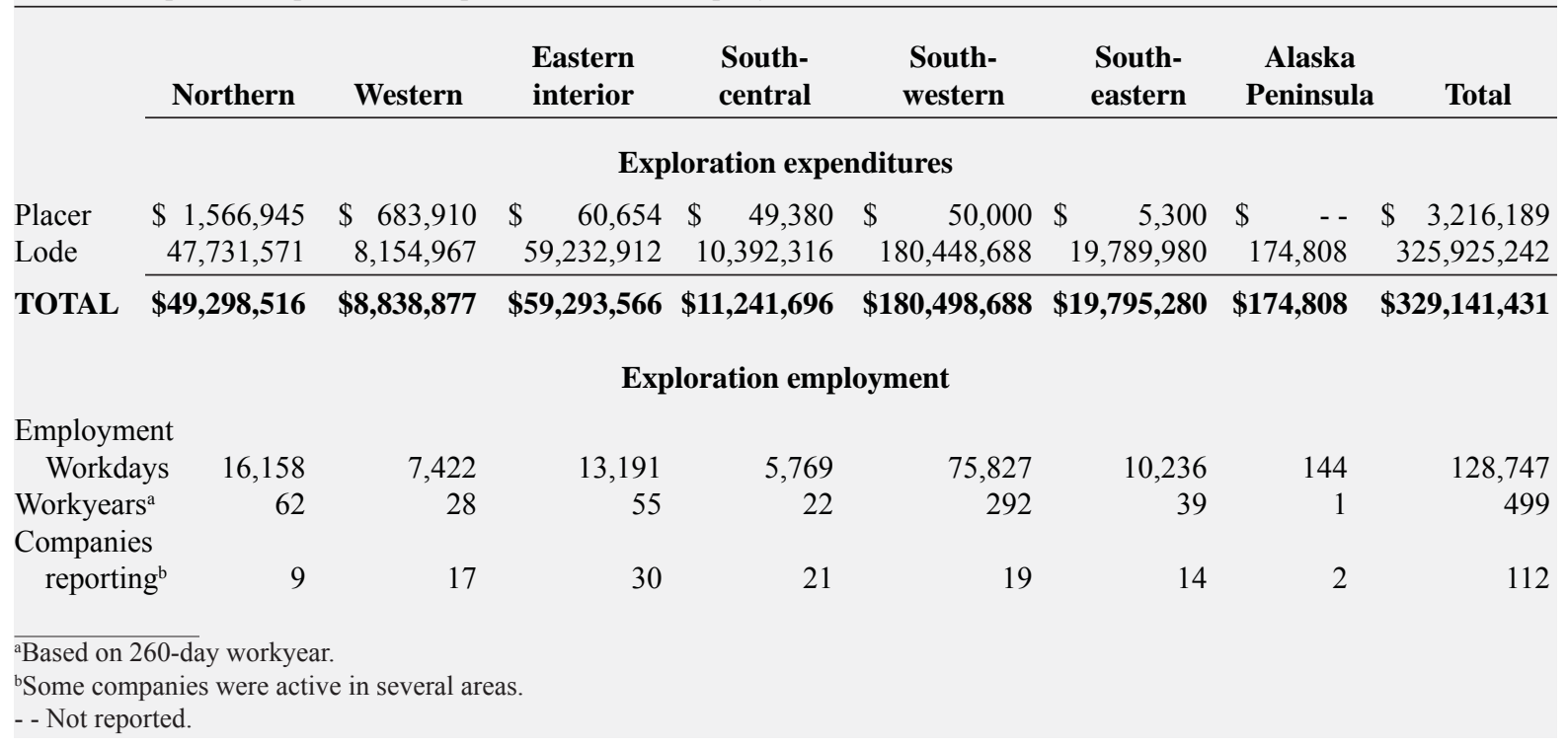




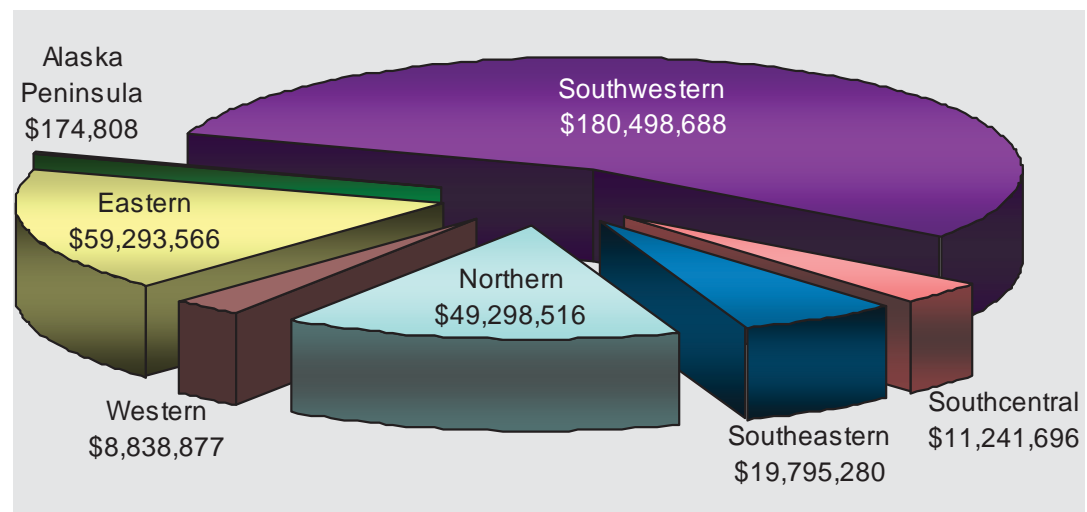

Figure 10. 2007 Alaska exploration expenditures by region.

South, and Chisna projects. Continued exploration around the Fort Knox and Greens Creek mines made discoveries that extended mine resources. Exploration for intrusion-related gold deposits in southwestern and Interior Alaska continued at the Livengood, Liberty Bell, Gold Hill, Kisa, and Vinasale projects. Work on high-grade gold-quartz veins was conducted at the Terra, Pogo, Lucky Shot, Golden Summit, Rob, Maple Leaf, Ganes Creek, Blue Quartz, and Little Squaw projects. Base-metal exploration was conducted at the Red Dog, Lik-Su, Arctic, and Sun SEDEX and volcanogenic massive sulfide (VMS) properties in the Brooks Range, at the Greens Creek Mine, the Palmer and Niblack properties in southeastern Alaska, and at the LWM project in the eastern Interior region. Platinum and associated metals exploration continued at the MAN project in the Alaska Range and in the Goodnews Bay area. Other exploration continued for uranium (Boulder Creek, Bokan Mountain), diamonds (Yenlo Hills), placer gold (Little Squaw), and coal (Point Lay).

Table 6 summarizes the number of new and active (new plus existing) mining claims per year, from 1991 to 2007. The table lists the number of 20 -acre federal mining claims, 160-acre state prospecting sites, and 40or 160 -acre state mining claims. About 6,607 new state mining claims (987,440 acres), 57 new state prospecting sites (9,120 acres), and 933 new federal claims (18,660 acres) were staked in 2007. State claim staking increased

Table 6. Summary of claim activity by acres, 1991-2007

\begin{tabular}{|c|c|c|c|c|c|c|c|c|}
\hline \multirow[b]{2}{*}{ Year } & \multicolumn{4}{|c|}{ State Claims } & \multicolumn{2}{|c|}{ State Prospecting Sites } & \multicolumn{2}{|c|}{ Federal Claims } \\
\hline & $\begin{array}{c}\text { New } \\
\text { (Active) } \\
40 \text { acre }^{\mathrm{a}}\end{array}$ & $\begin{array}{c}\text { New } \\
\text { (Active) } \\
160 \text { acre }\end{array}$ & $\begin{array}{c}\text { Total } \\
\text { (Active) } \\
40 \text { acre }^{a}\end{array}$ & $\begin{array}{c}\text { Total } \\
\text { (Active) } \\
160 \text { acre }\end{array}$ & New & Total & New & Total \\
\hline 1991 & 3,277 & 0 & 37,862 & 0 & 747 & 1,723 & 1,299 & 23,222 \\
\hline 1992 & 2,640 & 0 & 36,250 & 0 & 454 & 1,472 & 695 & 20,254 \\
\hline 1993 & 2,120 & 0 & 34,340 & 0 & 1,412 & 2,259 & 601 & 9,298 \\
\hline 1994 & 4,057 & 0 & 34,400 & 0 & 802 & 2,378 & 341 & 8,495 \\
\hline 1995 & 4,512 & 0 & 30,464 & 0 & 1,030 & 2,725 & 376 & 7,766 \\
\hline 1996 & 9,489 & 0 & 36,602 & 0 & 2,082 & 3,687 & 681 & 9,346 \\
\hline 1997 & 8,678 & 0 & 42,836 & 0 & 2,480 & 5,305 & 1,872 & 11,320 \\
\hline 1998 & 9,786 & 0 & 49,816 & 0 & 3,194 & 7,148 & 427 & 11,033 \\
\hline 1999 & 11,978 & 0 & 56,107 & 0 & 1,755 & 7,600 & 308 & 10,176 \\
\hline 2000 & 4,560 & 614 & 54,393 & 614 & 1,143 & 5,675 & 523 & 7,805 \\
\hline 2001 & 858 & 907 & 49,627 & 1,503 & 27 & 3,091 & 464 & 8,248 \\
\hline 2002 & 745 & 826 & 44,056 & 2,179 & 61 & 2,138 & 261 & 8,100 \\
\hline 2003 & 856 & 2,603 & 38,076 & 4,387 & 101 & 1,857 & 676 & 8,424 \\
\hline 2004 & 1,070 & 3,533 & 34,380 & 7,719 & 59 & 1,484 & 66 & 8,313 \\
\hline 2005 & 806 & 4,502 & 34,066 & 11,551 & 128 & 1,612 & 411 & $8,200^{\mathrm{b}}$ \\
\hline 2006 & 1,111 & 5,747 & 33,864 & 16,249 & 103 & 1,646 & 457 & $7,805^{\mathrm{b}}$ \\
\hline 2007 & 576 & 6,031 & 31,305 & 20,208 & 57 & 1,625 & 933 & $8,820^{\mathrm{b}}$ \\
\hline
\end{tabular}


2.5 percent from 2006 levels, while the number of new federal mining claims more than doubled from 2006 to 2007, and was more than 14 times as high as the number of new federal mining claims in 2004. The number of active federal claims reached its highest level in 8 years during 2007. State mining leases covered 48,029 acres of land, and offshore mining leases or permits totaled 131,841 acres. The amount of land in Alaska under claim increased from 2006 to 2007, with approximately 4.63 million acres of land covered by claims and prospecting sites in 2007 . This acreage is an increase of 4.3 percent from 2006 levels and the largest amount of land covered by mining claims, prospecting sites, and mining leases for the past decade. Alaska had 8,820 active federal mining claims in 2007.

Prospecting sites and mining claims were staked across Alaska, with detailed information listed in Appendices A and B. Several large blocks of mining claims were staked in 2007. In southwestern Alaska, Anglo American Exploration Inc. staked seven hundred five 160 -acre state mining claims covering 112,800 acres bordering Lake Clark National Monument just northwest of Lake Clark. Millrock Resources Inc. also staked 124 state mining claims in the area, abutting the Anglo claim group to the west. NovaGold Resources Inc. staked 125 claims (20,000 acres) north of Kisaralik Lake and west of Gemuk Mountain. Nearby, Gold Crest Mines Inc. staked the Luna claims west of the Kisa claim block, as well as four additional claim blocks 45 miles northeast of the Kisa prospect.

NovaGold Resources Inc. staked six hundred three 160 -acre claims covering 96,480 acres on the Seward Peninsula west of the Kiwalik Mountains and east of the Kugruk River. Andover Ventures Inc. staked 87 state mining claims to the west of the Sun claim block in the central Brooks Range. At the Tanacross Project, Full Metal Minerals Ltd. staked seven claim groups covering syngenetic massive sulfide and copper-gold-molybdenum porphyry targets. Millrock Resources Inc. staked three blocks of state mining claims in the Fortymile mining district. Rhyolite Resources Ltd. staked 18 mineral claims at the White Gold property.

Niblack Mining Corp. staked 45 additional federal lode mining claims surrounding the core Niblack claim block in southeastern Alaska. Niblack Mining also staked the Ruby Tuesday property near the Niblack property with 120 federal mining claims and the Cayenne property on Prince of Wales Island. Constantine Metal Resources Ltd. staked 27 state claims in the area of the Palmer property, Quaterra Resources Inc. staked 67 federal claims around the Herbert Glacier property near Juneau, Pure Nickel Inc. staked 115 federal mining claims at the Salt Chuck property, and Landmark Minerals Inc. staked 100 federal claims on Bokan Mountain.

\section{NORTHERN REGION}

Silverado Gold Mines Ltd. continued placer and lode mineral exploration programs concurrent with underground drift mining activities at the Nolan Creek placer gold mine. During 2007, more than 6,000 feet of reverse-circulation (RC) drilling in 103 drill holes was completed at the Jack London Bench, a possible extension of the Mary's East deposit to the north, and eastern extensions of the Ogden-Eureka Bench, where buried channels might be found. Out of the 130 drill holes, 52 show the presence of gold, ranging from 0.001 to 0.055 ounces of gold per bank cubic yard. Lode surface exploration completed during 2007 included the expansion of the VLF-EM geophysical survey and soil grid in the generalized area known as the 'Solomon Shear Zone', and a VLF-EM geophysical survey and soil grid in the 'Fortress' vein-fault area of gold-bearing quartz veins between Nolan Creek and the Hammond River. The geophysical data are interpreted by Silverado to show northwest-striking structures offsetting dominantly northeast structural trends. Seven trenches, totaling 1,420 feet, were excavated by backhoe in the Solomon shear zone and 168 select chip and continuous chip rock samples were collected during the trenching program and analyzed. Results included values as high as 5.22 ounces of gold per ton and 8.74 percent antimony over 16.4 feet, with some select samples containing up to 48.07 percent antimony. Twelve drill holes totaling 2,715 feet tested the swarm of thin, closely spaced, stibnite-quartz veins and veinlets on Pingle Bench north of Smith Creek. Seven holes totaling 2,301 feet tested the Workman's bench stibnite-quartz zone. Sample results include 19 feet grading 0.078 ounces of gold per ton and 3.24 percent antimony in hole $07 \mathrm{SH} 01,11.4$ feet grading 0.057 ounces of gold per ton and 4.99 percent antimony in hole 07SH14, and 5 feet grading 0.057 ounces of gold per ton and 3.45 percent antimony in hole $07 \mathrm{SH} 015$. Silverado also collected 989 soil samples in the Workman's Bench, Hillside, and Fortress areas.

Zazu Metals Corp. concluded an agreement with GCO Minerals Co. and purchased a 50 percent interest in the Lik deposit near the Red Dog Mine for \$20 million, with the remaining interest held by Teck Cominco Ltd. Under the Lik Block Agreement, Zazu (as successor to GCO) may earn an additional 30 percent equity interest from Teck Cominco by qualifying expenditures prior to 2018 of \$25 million, which are to be adjusted for inflation indexing and escalations. The adjusted amount is estimated to be about $\$ 40$ million. Zazu completed an 11hole diamond drilling program with an aggregate depth of 4,574 feet. The drilling confirmed previous drilling results, filled in some portions of the deposit, and provided samples for metallurgical testing. Drill intercepts include hole DDH-136 with 42 feet grading 9.78 percent 
zinc and 1.61 percent lead starting at a 270 -foot depth, hole DDH-137 with 139 feet grading 6.49 percent zinc and 1.67 percent lead starting at a 112-foot depth, hole DDH-138 with 84 feet grading 8.20 percent zinc and 2.44 percent lead starting at a 23 -foot depth, and hole DDH-143 with 52 feet grading 14.05 percent zinc and 9.41 percent lead starting at a 255 -foot depth.

Andover Ventures Inc. purchased the remaining interest in the Sun property to complete 100 percent ownership in the property, and staked 87 state mining claims to the west of the original claim block. Andover continued exploration of the Sun volcanogenic massive sulfide occurrences, including collecting 760 soil and rock samples and a 20-hole diamond drilling program totaling 14,750 feet. Drilling at the Main Sun deposit was spaced along fences approximately 500 feet apart with holes spaced approximately 160 feet down dip of the known mineral zones. Drill results include massive sulfide mineralization in 39 horizons ranging in thickness from 5 to more than 100 feet in 19 of 20 holes. The 39 horizons encountered averaged more than 22 feet in thickness of massive and semi-massive mineralization to a depth of 820 feet and a strike length of 4,600 feet. Average grade was 1.5 percent copper, 1.0 percent lead, 3.85 percent zinc, 1.84 ounces of silver per ton and 0.008 ounces of gold per ton. Selected drill intercepts include: hole Sun-07-10 with an upper, 35.8-foot intercept of 2.34 percent copper, 0.77 percent lead, 5.98 percent zinc, 1.99 ounces of silver per ton, and 0.008 ounces of gold per ton; and a 16.7-foot lower intercept of 4.34 percent copper, 0.58 percent lead, 2.76 percent zinc, 2.89 ounces of silver per ton, and 0.006 ounces of gold per ton; hole Sun-07-12 with a 106.4-foot intercept of 1.04 percent copper, 0.80 percent lead, 2.83 percent zinc, 2.37 ounces of silver per ton, and 0.008 ounces of gold per ton; hole Sun-07-13 with a 121.4 -foot intercept of 1.17 percent copper, 1.85 percent lead, 7.26 percent zinc, 1.28 ounces of silver per ton, and 0.005 ounces of gold per ton; and hole Sun-07-14 with a 99.1-foot intercept of 1.06 percent copper, 0.69 percent lead, 2.03 percent zinc, 1.25 ounces of silver per ton, and 0.010 ounces of gold per ton.

Drilling by Andover Ventures indicated that mineralization at the Sun property extended to the Picnic Creek area 1,100 feet to the north of the main prospect, with the discovery of the Hot zone. Hole Sun-07-06 intersected 103 feet of the Hot zone with an average grade of 0.90 percent copper, 0.40 percent lead, 1.50 percent zinc, and 0.461 ounces of silver per ton. Hole Sun-07-17 intersected 28.2 feet grading 0.80 percent copper, 0.60 percent lead, 2.60 percent zinc, and 0.983 ounces of silver per ton. Andover reported intersecting a new thicker zone, averaging 116 feet in depth and 1.05 percent copper, 0.81 percent lead, 3.26 percent zinc, and 1.251 ounces of silver per ton in the three holes from the southernmost fence. This new mineralization extends the main Sun deposit about 1,650 feet to the south and leaves it open in that direction.

Little Squaw Gold Mining Co. drilled 15,550 feet in 111 reverse-circulation placer drill holes, distributed on 11 drill lines spaced 500 feet apart. A total of 3,110 drill samples were collected. Drilling identified at least 7.5 million cubic yards of mineralized material in the Little Squaw Creek drainage. The pay horizon was intersected in 73 holes and averaged $\$ 14.85$ per cubic yard over a thickness of 83 feet using a gold price of $\$ 600$ per ounce, or $\$ 22.27$ per cubic yard at $\$ 900$ per ounce gold. Lateral limits and overall grade of the gold-bearing gravels containing the potentially economic "pay horizon" have not been fully delineated and other drainage systems remain to be tested. Lode exploration during 2007 on the Little Squaw property included soil and rock geochemical sampling, ground magnetic surveys, geologic mapping, and extensive excavator trenching. Trenching on the Summit prospect cut a 20 -foot wide, east-west-trending structure with irregular quartz lenses that assayed 0.309 ounces of gold per ton.

Teck Cominco Ltd. continued exploration for additional SEDEX deposits in the Red Dog area. Drilling intersected encouraging sulfide intervals that warrant additional drilling in 2008.

BHP Billiton Ltd. drilled the coalfields in the western Arctic on land owned by Arctic Slope Regional Corp. In 2007, BHP drilled nine holes to test the thickness of the coal seams and evaluate the quality of the coal in the historic Kuchiak Mine area that Arctic Slope tested in 1994 (fig. 11). BHP also began environmental baseline studies and initiated cleanup activities at the Kuchiak Mine during the year. More than 45 people from Point Hope and Point Lay worked on the Western Arctic Coal Project at some point this year.

NovaGold Resources Inc. continued exploration at their Ambler property in the southern Brooks Range. The 2007 program included nearly 10,000 feet of core drilling in five holes. Two holes about 0.3 miles north of the Arctic deposit intersected a deeper limb of the complex fold containing the Arctic massive sulfide deposit, and up to 33 feet of weak mineralization and chlorite-talc alteration. SRK Consulting (U.S.) Inc. was contracted to upgrade the historical Ambler resource to an NI 43-101 ${ }^{3}$ compliant estimate. The Ambler project is estimated to contain an indicated resource of 1.5 billion pounds of copper, 2.2 billion pounds of zinc, and 0.4 million ounces of gold, with an additional inferred resource of 0.9 billion pounds of copper, 1.3 billion pounds of zinc, and 0.3 million ounces of gold. The indicated resource

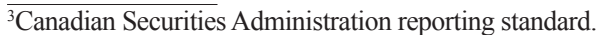


contains 18.51 million tons with an average grade of 4.14 percent copper, 6.03 percent zinc, and 0.023 ounces of gold per ton. The inferred resource contains 13.11 million tons with an average grade of 3.56 percent copper, 4.99 percent zinc, and 0.020 ounces of gold per ton. The average metal content exceeds 8 percent copper equivalent, as calculated by NovaGold.

NovaGold Resources Inc. continued exploration in the Baird Mountains. NovaGold acquired its initial land holdings in the area in 2006 by staking the Frost, Deadfall and Peak occurrences and subsequently optioned the Omar property from Aur Resources Inc. Fieldwork in 2007 included collection of 3,304 soil samples, 355 rocks, 144 silt samples, 45 pan concentrate samples, and 23 talus fine samples along with detailed and broadscale mapping of the mineralized areas. NovaGold rock samples at the Omar prospect include up to 34.3 percent copper, 0.85 percent zinc, and 0.4 percent cobalt from select samples along chalcopyrite-bornite-chalcocite mineralized and brecciated dolostone. A 200 ppm copper anomaly in soils and talus fines defines a 2 mile by 0.3 mile area. Significant zinc and cobalt soil anomalies mimic the copper mineralization at the Omar prospect. Continuous channel sampling of a 154-foot-wide, steeply dipping zone of disseminated coarse-grained sphalerite and galena in recrystallized dolomite at the Deadfall prospect returned 39 feet of 10.1 percent zinc and 1.24 ounces of silver per ton. The zone trends eastward to a 2.5 mile by 1 mile zinc and lead soil and talus fine anomaly. Select rock samples from a massive barite-sulfide-fluorite zone with sphalerite, galena, bornite, and chalcopyrite at the Frost prospect contain up to 30.6

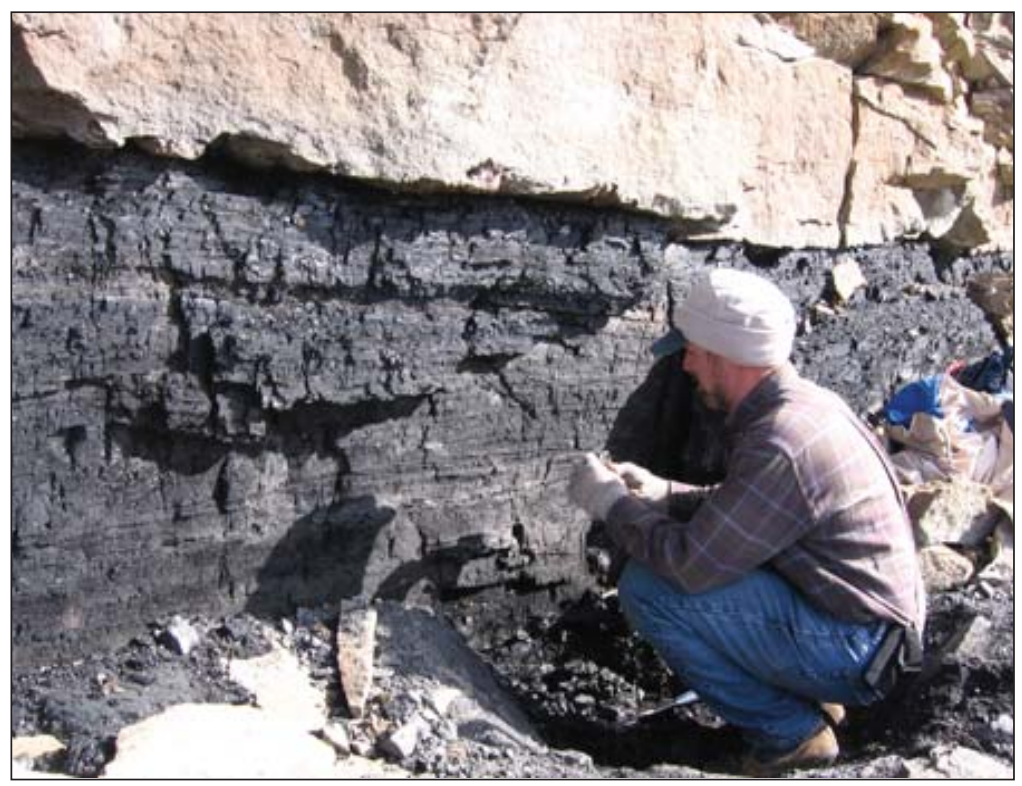

Figure 11. BHP Billiton Ltd. geologist examining coal seam near Point Lay. Photo provided by BHP Billiton Ltd. percent zinc, 20.2 percent copper, and 1.53 ounces of silver per ton. Soil and talus fine sampling defined a large copper and zinc anomaly at the Frost prospect. NovaGold also sampled smithsonite encrustations and coarsely crystalline disseminated sphalerite, galena, and massive barite along a 10-mile linear zone at the Peak prospect, with select rock samples containing up to 33.1 percent zinc and 4.1 percent lead.

\section{WESTERN REGION}

NovaGold Resources Inc. completed 33,532 feet of reverse-circulation drilling focused on exploration leases around the Rock Creek Mine, including significant work on the Saddle deposit, as well as the Mt. Distin lease area, adjacent state claims, and the Big Hurrah exploration area. Drilling around the pit margin at Rock Creek continues to show positive results, indicating potential resource expansion. At Big Hurrah, an extensive soil sample program identified at least three significant new gold-in-soil targets for further evaluation.

NovaGold also continued exploration on the Kugruk property, near the historic Independence Mine on the northern Seward Peninsula. Work in 2007 followed up targets identified in a 2006 airborne electromagnetic survey. NovaGold collected approximately 2,000 soil samples in 2007 from wide-spaced east-west lines placed across the Kugruk pluton and across other mineralized trends and geophysical anomalies on the property. Copper soil anomalies were associated with the margin of the Kugruk pluton and cover a second apparent intrusive center farther south. Silver, lead, and zinc anomalies were detected along the trend of the historic base-metal prospects. NovaGold also assayed historic drill core from 1978 drilling by Placid Oil Co. at a magnetite-rich copper-iron skarn on the east margin of the Kugruk pluton. Highlights from the NovaGold sampling of the remaining core include DDH20-78 with 127 feet of 60.8 percent iron and 0.11 percent copper, and DDH6-78 with 85 feet of 60.9 percent iron and 0.08 percent copper.

Mystery Creek Resources Inc., a wholly owned subsidiary of St. Andrew Goldfields Ltd., continued underground and surface exploration drilling at the Nixon Fork project. The drill program continued through the winter. 
Full Metal Minerals Ltd. and Triex Minerals Corp. completed first-pass drilling at the Boulder Creek uranium deposit, with 2,920 feet of drilling in eight holes. No new and continuous zones of significant radioactivity were intersected. Concurrent regional exploration discovered new uranium mineralization, named the Fireweed occurrence, located to the north in Death Valley. The regional program focused on two areas with strong airborne radiometric anomalies, and geologic settings similar to that of the Boulder Creek deposit. A total of 1,790 soil samples were collected over 73 line-miles at McCarthy Marsh, 18 miles west of Boulder Creek, and 230 soil samples were collected over 13 line-miles over the new Fireweed occurrence 15 miles north along-strike from Boulder Creek. A ground magnetic susceptibility survey was completed over the entire McCarthy Marsh grid, and a portion of the Fireweed grid. Detailed mapping and scintillometer prospecting were done in both areas. A total of 129 biogeochemical samples were also collected from these two grid areas. Uranium content ranges from 0.14 percent to 0.81 percent $\mathrm{U}_{3} 0_{8}$ in 21 rock samples collected from three main areas spanning the 1-mile width of the Fireweed prospect. The grid of 230 soil samples at Fireweed produced an anomaly area coincident with the area of mapped radioactive pebbles, with values of up to $145 \mathrm{ppm}$ uranium in soil. A quick, first-pass drill test was done at Fireweed in September following completion of the main drill program at the Boulder Creek deposit. Five short drill holes were completed for a total of 876 feet. Overburden in four of five holes was only 5 feet thick. Quartz syenite is predominant, and in all five holes there are intervals with 2 to 3 times background radioactivity.

Millrock Resources Inc. formed a joint venture with Alix Resources Corp. (formerly NPN Investment Group) to explore the Divide property on the Seward Peninsula. Millrock will secure a 50 percent interest in the project by paying 50 percent of all costs associated with the Divide Option - a total of $\$ 500,000$ over a 5-year period. Additionally Millrock will issue 500,000 shares to NPN. The Divide Option will require Millrock and NPN to pay a sliding-scale net smelter return royalty ranging between 2 and 5 percent on production of precious metals and 3 percent on base and other metals. Five holes totaling 1,841 feet were drilled to test an 8,000-foot-long by 2,000-foot-wide gold-arsenic soil anomaly. Drilling highlights include 29.5 feet, starting at 157 -foot depth, grading 0.044 ounces of gold per ton in hole DIV-0703, 10 feet, starting at 306.5-foot depth, grading 0.29 ounces of gold per ton in hole DIV-07-04, and 27 feet, starting at 7-foot depth, grading 0.169 ounces of gold per ton in hole DIV-07-05.

Millrock also has the option to earn a 60 percent interest in the Inmachuk property from Full Metal
Minerals. Drilling focused on the Hannum zone, where a 2,500-foot drilling program consisting of five holes explored for carbonate-hosted silver-lead-zinc mineralization. The mineralized zone exposed at surface and in shallow historic drilling was intersected along strike and down dip. Hole 1002IM intersected 10 feet grading 1.25 percent zinc starting at 33 -foot depth, hole 1004IM intersected 21.7 feet grading 2.06 percent zinc starting at 63-foot depth, and hole 1005IM had a 2-foot intercept grading 5.55 percent zinc and 3.66 percent lead, and a 3 -foot intercept grading 4.56 percent zinc starting at 52 and 68.9 feet, respectively.

Andover Ventures worked on the Bulk Gold property 22 miles north of Nome. Andover drilled seven holes at Bulk Gold in 2007, totaling about 2,100 feet. The drilling focused on testing the down-dip potential of the old Hed \& Strand vein in hole BG-07-01 as well as the 5,000-foot-long Dorothy Creek soil anomaly in holes BG-07-05 and BG-07-07. Drilling results for hole BG07-05 contained a 48-foot intercept of 0.03 ounces of gold per ton and hole BG-07-07 had a 34.6-foot intercept of 0.017 ounces of gold per ton.

Freegold Ventures Ltd. optioned the Vinasale gold property near McGrath from Doyon Ltd., an Alaskan Native regional corporation, and staked additional claims adjacent to the property. Exploration included the collection of stream silt and pan-concentrate samples and flying a 1,090-line-mile high-resolution electromagnetic and magnetic geophysical survey over the project area.

Gold Crest Mines Inc. explored for gold mineralization hosted in quartz-carbonate-clay altered, stockwork-veined and brecciated carbonaceous schist and carbonate at the Kelly Creek Project, about 90 miles northwest of Nome, under an exploration lease and option to purchase agreement with Greatland Exploration Ltd. The 2007 program included collection of more than 330 rock, soil, and stream-sediment samples. This work expanded two known prospects, $\mathrm{KC}$ and Ox, and discovered three new prospect areas. The newly discovered Wolverine prospect has a 500 -foot-wide by 1,500-foot-long soil anomaly with values ranging from 15 to 1,146 parts per billion gold.

Great Basin Gold Ltd. optioned the Ganes Creek gold property from Clark/Wiltz Mining Co. and conducted an extensive trenching program. Terms of the agreement require minimum 2007 exploration expenditures of $\$ 800,000$, followed by an additional $\$ 1$ million by the end of 2008 and a final $\$ 1.2$ million in expenditures by the end of 2009. Approximately 32,000 feet of trenching was completed with a Caterpillar D-7 and a Hitachi EX160 excavator. Some of the trenches were not sampled due to time constraints, but 1,685 rock samples, mostly continuous chip samples, were collected and analyzed. 
Minor amounts of placer gold exploration continued across the region, especially on the Seward Peninsula. Paul Sayer conducted trenching at Ester Creek in the Innoko mining district.

\section{EASTERN REGION}

Kinross Gold Inc. continued mine site exploration at Fort Knox Mine by drilling for a possible Phase 7 mine expansion. More than 166,000 feet of drilling was completed by five drill rigs. The exploration contributed 1.2 million ounces of gold to year-end reserves.

Freegold Ventures Ltd. conducted a 679-hole, 40,100 -foot drill program that resulted in the discovery of new high-grade veins and bulk tonnage shear zones on its Golden Summit project near Fairbanks. Shallow, closely spaced holes were drilled during the year in 18 different fences. These fences were oriented to provide cross sections through the 5,000 -foot-long by 2,000 foot-wide zone of mineralization previously identified by surface trenching in 2005 and 2006 and with the first bulk sampling conducted in late 2006. Some of the higher-grade intersections from this drilling included 6 feet of 0.682 ounces of gold per ton (Fence 3 ); 3 feet of 1.070 ounces of gold per ton and 3 feet of 0.647 ounces of gold per ton, (Fence 4); 3 feet of 1.032 ounces of gold per ton, 6 feet of 0.636 ounces of gold per ton, and 9 feet of 0.738 ounces of gold per ton (Fence 5); 3 feet of 0.671 ounces of gold per ton, 3 feet of 0.519 ounces of gold per ton, and 3 feet of 0.528 ounces of gold per ton (Fence 6); 3 feet of 0.992 ounces of gold per ton and 3 feet of 0.662 ounces of gold per ton (Fence 9); 3 feet of 1.464 ounces of gold per ton, 3 feet of 1.015 ounces of gold per ton, and 3 feet of 0.639 ounces of gold per ton (Fence 11); 9 feet of 0.831 ounces of gold per ton (Fence 16); and 3 feet of 0.787 ounces of gold per ton (Fence 18). The 2007 drilling also identified multiple parallel zones of lower-grade mineralization over widths from 100 to 600 feet, which are traceable from fence to fence across the open-ended, mile-long zone. For example, Fence 1 had a 620 -foot north-south width grading 0.020 ounces of gold per ton and fence 5 had a 275 -foot-wide zone grading 0.035 ounces of gold per ton and a 300 -foot-wide zone grading 0.020 ounces of gold per ton. These low-grade gold zones appear to widen as they trend from east to west. Gold grades compare favorably to the average mill feed grade at Fort Knox Mine in 2006. Freegold also continued the bulk sampling program in the Beistline shaft and the Fence 1 areas, and permitted and constructed a 1,200-ton-perday portable gravity circuit in order to recover the gold from the bulk samples.

Freegold also worked on the Rob property in the Goodpaster area. High-grade gold mineralization was intersected in all eight core holes (1,529 feet of drilling) drilled into the Gray Lead vein (including 0.846 ounces of gold per ton over 13 feet and 0.586 ounces of gold per ton over 13.5 feet) over a strike length of 170 feet and a down-dip length of 240 feet. Gold mineralization is in sugary-textured quartz veins, containing fine-grained bismuthinite and arsenopyrite, within a biotite augen gneiss host rock. Nine holes totaling 1,985 feet were drilled at the O'Reely vein and intersected non-mineralized or weakly mineralized (anomalous gold with values up to 0.061 ounces of gold per ton over 3 feet, and 0.027 ounces of gold over 17 feet) quartz veins hosted in altered biotite granodiorite.

International Tower Hill Mines Ltd. is earning a 60 percent interest from Anglo Gold Ashanti (USA) Exploration Inc. in the LMS project. The LMS project is located along the Pogo Mine winter access road approximately 9 miles from the paved Richardson Highway. International Tower Hill completed an extensive, deep auger drill soil sampling program across the LMS property, discovered two previously unknown areas of mineralization (at Liscum and NW Camp), and better defined the known NW and South Ridge anomalies. A total of 1,735 samples were collected at the LMS property in 2007, including traditional pit soil samples, deep auger drill soil samples, and mobile-metal-ion soil samples. International Tower Hill completed an initial mineral resource estimate for the Camp Zone deposit at its LMS project near Delta Junction. Gold mineralization within the Camp Zone is associated with a siliceous breccia horizon within a schist unit. The independent study determined an initial inferred gold resource of 167,000 ounces of gold at a cutoff grade of 0.009 ounces of gold per ton with an average grade of 0.026 ounces of gold per ton.

International Tower Hill discovered a potential large, bulk tonnage, road-accessible gold deposit on its Livengood project northwest of Fairbanks. Drilling results, with 15 core holes in 2007, outlined an open-ended zone of gold mineralization approximately 1.2 miles long and more than 0.3 miles wide, with an average mineralization thickness of 279 feet exceeding 0.007 ounces of gold per ton. Significant 2007 drill results are listed in table 7. Mineralization consists of gold in multiple stages of quartz veins associated with variable amounts of pyrite, arsenopyrite, stibnite, and minor to trace amounts of other sulfides. Mineralization is stratabound, controlled by structures and stratigraphy, primarily hosted in a folded sequence of volcanic and calcareous sedimentary rocks and averages 0.025 ounces of gold per ton. The target horizon lies under a large gold-in-soil anomaly, is 600 to 1,000 feet thick, and dips shallowly to the south. The new sediment-hosted mineralization is characterized by decalcification, chaotic fracturing, strong oxidation, and pervasive silicification. The highest grade areas of these 
new zones are associated with strong decalcification and albitic alteration and commonly contain stibnite. Based on the highly encouraging 2007 results, International Tower Hill outlined an approximate 150-hole drill program for 2008 .

International Tower Hill also worked on the Chisna project in the Chistochina area north of the Glenn Highway. Fugro World Wide was contracted to fly an aeromagnetic and electromagnetic survey over the prop- erty, covering 46.3 square miles on 656-foot line spacing. Exploration identified two new dioritic porphyry systems with elevated hydrothermal magnetite and associated gold-copper mineralization. Preliminary work had anomalous gold and copper values from surface soil and rock chip sampling over an area of approximately 0.4 square miles centered on a partially exposed mineralized porphyry system. Initial rock samples from this area average 0.085 ounces of gold per ton and 0.68 percent

Table 7. International Tower Hill Mines Ltd. (Talon Gold) 2007 significant drill results at the Livengood property

\begin{tabular}{|c|c|c|c|c|c|}
\hline $\begin{array}{c}\text { Hole } \\
\text { Number }\end{array}$ & $\begin{array}{l}\text { From } \\
\text { (feet) }\end{array}$ & $\begin{array}{c}\text { To } \\
\text { (feet) }\end{array}$ & $\begin{array}{l}\text { Length } \\
\text { (feet) }\end{array}$ & $\begin{array}{c}\text { Gold Grade } \\
\text { (ounces per ton) }\end{array}$ & Host rock \\
\hline MK-07-12 & 259.4 & 270.4 & 11.0 & 0.109 & upper volcanic unit \\
\hline MK-07-12 & 360.6 & 393.4 & 32.8 & 0.043 & upper volcanic unit and fault zone \\
\hline MK-07-13 & 33.6 & 55.0 & 21.4 & 0.037 & fault zone and shale \\
\hline MK-07-13 & 320.8 & 394.0 & 73.3 & 0.023 & upper volcanic unit \\
\hline MK-07-13 & 931.5 & 953.8 & 22.3 & 0.033 & lower volcanic unit \\
\hline MK-07-14 & 114.0 & 147.0 & 33.0 & 0.018 & fault zone \\
\hline MK-07-15 & 107.6 & 200.8 & 93.2 & 0.048 & upper volcanic unit and fault zone \\
\hline MK-07-15 & 262.2 & 496.5 & 234.4 & 0.029 & upper volcanic unit \\
\hline MK-07-16 & 617.7 & 640.5 & 22.7 & 0.034 & lower sandstone unit \\
\hline MK-07-17 & 385.8 & 507.2 & 121.4 & 0.024 & main volcanic unit \\
\hline MK-07-18 & 45.3 & 67.0 & 21.7 & 0.036 & sedimentary rocks \\
\hline MK-07-18 & 253.6 & 282.4 & 28.8 & 0.290 & sedimentary rocks \\
\hline MK-07-18 & 307.4 & 335.3 & 27.9 & 0.281 & sedimentary rocks \\
\hline MK-07-18 & 398.0 & 655.8 & 257.8 & 0.032 & volcanic rocks \\
\hline MK-07-19 & 149.3 & 173.7 & 24.4 & 0.043 & upper sedimentary rocks \\
\hline MK-07-19 & 234.0 & 255.9 & 21.9 & 0.036 & upper sedimentary rocks \\
\hline MK-07-19 & 391.3 & 437.2 & 45.9 & 0.014 & upper sedimentary rocks \\
\hline MK-07-19 & 469.0 & 484.9 & 15.9 & 0.031 & upper sedimentary rocks \\
\hline MK-07-19 & 588.8 & 617.0 & 28.2 & 0.016 & main volcanic unit \\
\hline MK-07-19 & 621.4 & 656.2 & 34.8 & 0.016 & main volcanic unit \\
\hline MK-07-19 & $1,088.4$ & $1,184.4$ & 96.0 & 0.017 & main volcanic unit \\
\hline MK-07-20 & 138.0 & 194.0 & 56.0 & 0.031 & upper sedimentary rocks \\
\hline MK-07-20 & 232.1 & 292.0 & 59.9 & 0.020 & upper sedimentary rocks \\
\hline MK-07-20 & 417.0 & 607.2 & 190.2 & 0.035 & main volcanic unit \\
\hline MK-07-20 & 643.1 & 690.8 & 47.8 & 0.024 & lower sedimentary rocks \\
\hline MK-07-21 & 15.0 & 35.8 & 20.8 & 0.071 & upper plate rocks \\
\hline MK-07-21 & 442.9 & 495.3 & 52.3 & 0.031 & main volcanic unit \\
\hline MK-07-21 & 543.0 & 584.3 & 41.3 & 0.021 & main volcanic unit \\
\hline MK-07-21 & 607.0 & 651.0 & 44.0 & 0.016 & main volcanic unit \\
\hline MK-07-21 & 832.0 & 922.2 & 90.2 & 0.018 & main volcanic unit \\
\hline MK-07-22 & 221.1 & 241.2 & 20.0 & 0.069 & sedimentary rocks \\
\hline MK-07-22 & 261.2 & 366.7 & 105.5 & 0.022 & sedimentary rocks \\
\hline MK-07-22 & 468.4 & 476.2 & 7.8 & 0.086 & sedimentary rocks \\
\hline MK-07-22 & $1,018.2$ & $1,191.7$ & 173.4 & 0.017 & volcanic rocks \\
\hline MK-07-23 & 248.3 & 259.2 & 10.9 & 0.105 & sedimentary rocks \\
\hline MK-07-23 & 331.6 & 341.9 & 10.3 & 0.058 & sedimentary rocks \\
\hline MK-07-23 & 414.7 & 510.3 & 95.5 & 0.019 & sedimentary rocks \\
\hline MK-07-23 & 538.4 & 560.3 & 21.9 & 0.022 & volcanic rocks \\
\hline MK-07-23 & 616.3 & 824.2 & 207.9 & 0.023 & volcanic rocks \\
\hline MK-07-24 & 481.0 & 492.0 & 11.0 & 0.040 & sedimentary rocks \\
\hline MK-07-24 & 505.3 & 521.4 & 16.1 & 0.028 & sedimentary rocks \\
\hline MK-07-24 & 601.6 & 675.9 & 74.3 & 0.014 & sedimentary rocks \\
\hline
\end{tabular}


copper. The average assay of 246 rock samples taken over a 2.75-square-mile area in the Chisna Southeast area was 0.011 ounces of gold per ton, 0.041 ounces of silver per ton, and 0.08 percent copper. Sixty-three soil samples were also collected in the Chisna Southeast area.

International Tower Hill continued work on the Coffee Dome project on Cleary Summit. Work in 2007 defined a number of high-grade gold veins in trenches, with rock sample results up to 4.871 ounces of gold per ton, and three large gold-in-soil anomalies along a 2.5-mile trend. International Tower Hill also signed a two-stage exploration agreement with option to lease with the University of Alaska for approximately 3,200 acres of land lying to the north of the existing Coffee Dome project.

International Tower Hill drilled its West Tanana project held under lease from Doyon Ltd. Highlights include a 4-inch-wide quartz vein with visible gold within a 1-foot drill interval in hole WT-07-02 assaying 0.45 ounces of gold per ton and a broader breccia zone returning 0.07 ounces of gold per ton over 14 feet. International Tower Hill interpreted, based on the drill results, a shallow easterly dipping zone of broad gold mineralization related to a series of stacked low-angle shear zones, with a possible high-angle feeder zone of quartz veins and breccia.

Full Metal Minerals Ltd. drilled the Fish and LWM prospects on the 40 Mile property (fig. 12). All six holes intersected carbonate replacement deposit-style massive sulfide mineralization. Drill hole LWM07-17 returned a 43-foot intersection grading 13.3 percent zinc, 4.64 ounces of silver per ton, 9.5 percent lead, and 0.3 percent

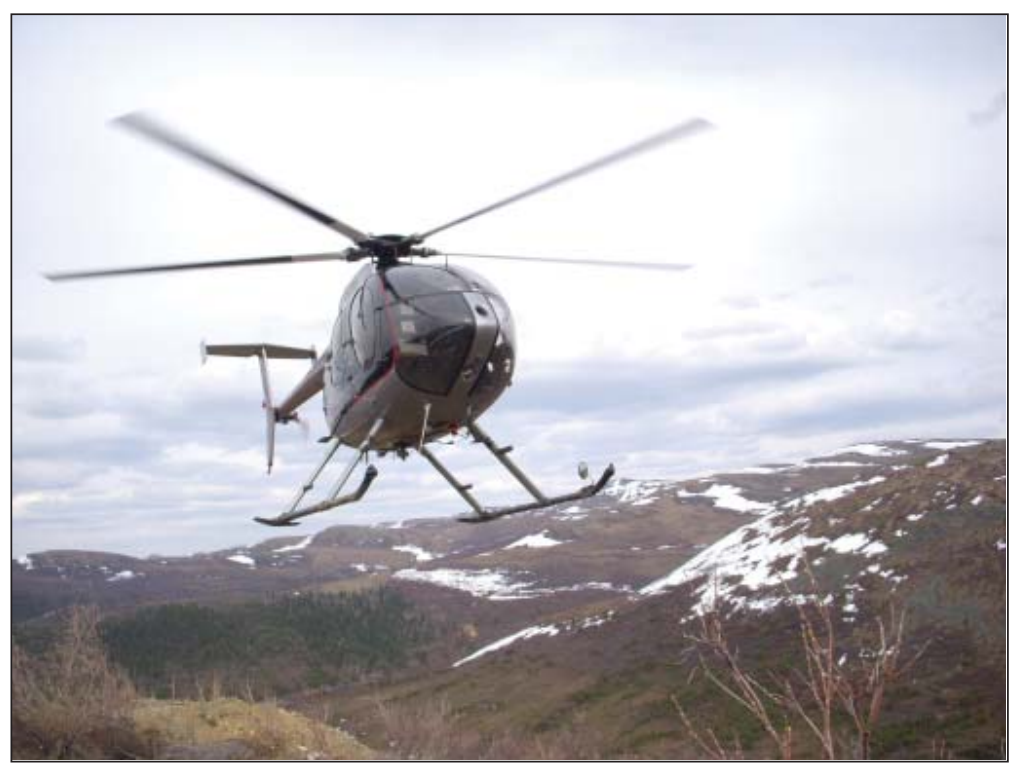

Figure 12. Helicopters were a vital transportation means during Full Metal Minerals Ltd.'s exploration program in the Fortymile mining district. Photo courtesy of Full Metal Minerals Ltd. copper of carbonate replacement style massive sulfide mineralization. The hole was drilled 130 feet west of hole LWM07-04, which intersected 146.3 feet grading 15.9 percent zinc, 5.3 percent lead, and 2.23 ounces of silver per ton. Other drill intercepts include a 27.9-foot intercept in hole LWM07-05 grading 12.3 percent zinc, 8.0 percent lead, and 3.07 ounces of silver per ton; a 51.2-foot intercept in hole LWM07-07 grading 21.2 percent zinc, 8.7 percent lead, 0.22 percent copper, and 3.70 ounces of silver per ton; and a 21.3-foot intercept in hole LWM07-09 grading 31.6 percent zinc, 11.3 percent lead, 1.41 percent copper, and 13.54 ounces of silver per ton. Both drilling and ground magnetic geophysics data suggest that the carbonate package hosting the massive sulfide mineralization dips toward the south and trends toward Full Metal's Fish prospect, 4 miles to the northeast. Three step-out drill holes were completed at the Fish zinc-silver oxide, carbonate replacement prospect on the 40 Mile property. The deepest hole drilled at Fish (hole Fish07-09) attempted to intersect primary sulfides; however, this hole encountered 26.4 feet averaging 12.3 percent zinc in mineralized material that was still oxidized.

Full Metal also collected surface samples from the Eva, Drumstick, and Oscar prospects. A total of 14 rock samples were collected from subcrop and historic prospect pits at the Eva Prospect, with best silver results of $108.79,57.17$, and 37.33 ounces of silver per ton. The average of all samples of mineralized rock from the Eva prospect was 27.91 ounces of silver per ton, 23.6 percent zinc, 12.6 percent lead, and 0.9 percent copper. At Drumstick, three samples of mineralized rock were collected from prospect pits and two of these samples returned 21.6 percent zinc, 19.1 percent lead, 6.47 ounces of silver per ton; and 11.6 percent zinc, 8.1 percent lead, and 25.17 ounces of silver per ton, in addition to anomalous gold and copper. One hundred rock samples were collected from two chalcopyrite-magnetite skarn outcrops at Oscar. The average of 38 samples from the upper outcrop was 0.6 percent copper and 0.895 ounces of silver per ton. The average of 62 samples from the lower outcrop was 0.16 percent copper, 0.19 percent zinc, and 0.134 ounces of silver per ton. A historic soil grid was extended at the Oscar prospect by collecting 222 soil samples during 2007. 
Teck Cominco Ltd. continued exploration on 1,230 Alaska state mining claims, mining leases, and millsite leases surrounding the Pogo Mine. Exploration was mostly a helicopter-supported two-rig surface drill program carried out from May 19 to September 7. Geological mapping, soil and rock sampling, and basic prospecting were also carried out in selected areas within the property. Exploration workers were housed at Pogo Mine's Lower Camp. Boart-Longyear (Salt Lake City, UT) was the drill contractor, providing two LF-70 type drill rigs. Helicopter services (H500D) were provided by Prism Helicopters (Wasilla). Approximately 2,800 drill core, soil, and rock samples were collected and analyzed for gold and other elements. Initial assays were done at the assay lab in the Pogo mill complex. Additional assays and geochemical work were contracted through Alaska Assay Labs in Fairbanks.

Rubicon Minerals Corp. acquired the New Horizon claims, a large group of mining claims in the Pogo area, from Evanachan Ltd., wholly owned by Robert McEwen, for a major stake in Rubicon through a minimum investment of $\$ 10$ million. Rubicon also optioned nearby claims (California North, ER-Ogo-Fire, Eagle-Hawk, California-Surf, and Bou-Swede) from Rimfire Minerals Corp. Under the terms of the Rimfire option agreement, Rubicon must complete expenditures totaling $\$ 4.8$ million in exploration over 6 years to earn a 60 percent interest in the five properties. Upon vesting, Rubicon may obtain an additional 10 percent interest in the properties by completing a feasibility study, and at Rimfire's election, may obtain an additional 5 percent (for a total of 75 percent). Project management, land management, and project-related work was carried out under the supervision of Avalon Development Corp. Prospecting identified a 1-square-mile area known as the Maple Leaf showing on the New Horizon claims, with 17 percent of samples (total 114 rock samples to date), containing an average of 0.15 ounces of gold per ton. Mineralization is characterized by sugary-textured quartz veins and, locally, stockwork veins associated with intrusive and country rock (gneiss and schist) containing trace to 2 percent sulfides containing arsenopyrite \pm bismuthinite \pm molybdenite and, locally, visible gold. A combination of grid and reconnaissance mapping, prospecting, and soil sampling (670 samples) was carried out on the California-Surf and Eagle-Hawk, Bou-Swede, and ER-Ogo-Fire properties. Weakly anomalous gold mineralization (up to 0.007 ounces of gold per ton over 2.6 feet) was encountered in a four-hole, 3,627-foot drilling program at the Maple Leaf showing. Rubicon also identified two new areas, the American Eagle and Tourmaline Ridge, with gold anomalies in quartz-veined granite and tourmaline-vein breccias and quartz-veined gneiss rock samples. Results from a seven-hole, 5,740- foot drill program at the Cal-Surf property include Hole CN07-01, drilled to test the California North gold and arsenic soil geochemical anomaly, with an intersection of quartz vein mineralization at a depth of 238 feet that averaged 0.035 ounces of gold per ton over a 24.3 -foot width, including an intercept of 0.065 ounces of gold over 8.2 feet. A later hole at California North intersected a 40-foot section of quartz-arsenopyrite mineralization that was anomalous in gold (maximum $70 \mathrm{ppb}$ gold over 4 feet).

Rimfire completed work on their claims in the Pogo area before the joint-venture agreement with Rubicon.

Rhyolite Resources Ltd. completed a three-hole 912-foot diamond drill program on the Super Cub target area of the Delta property. The program tested a gravity geophysical anomaly defined in 2006 , as well as the extension of siliceous-pyritic schist material found in outcrop. No significant mineralization was encountered. Rhyolite also staked 18 mineral claims at the White Gold property.

MAX Resource Corp. drilled the Gold Hill property in the Valdez Creek area with a five-hole program to test a broad molybdenum-copper-gold and geophysical magnetic anomaly. Hole DH-07-01 assayed a total of 0.048 percent molybdenum disulfide over the entire core length of 965 feet, with the best interval of 250 feet of 0.080 percent molybdenum disulfide beginning at 260 feet downhole. Copper mineralization occurs as chalcopyrite. Drill hole DH-07-03 returned 0.058 percent molybdenum disulfide over a core length of 1,000 feet, which included a higher grade intercept of 0.18 percent molybdenum disulfide ( 0.107 percent molybdenum) over 45 feet. Drill hole DH-07-05 had 0.0466 percent molybdenum disulfide over a core length of 822 feet, which included a higher grade intercept of 352 feet of 0.0706 percent molybdenum disulfide.

Metallica Resources Inc. conducted exploration at the Liberty Bell gold project in the western Bonnifield mining district after optioning the property. Under terms of the agreement, Metallica will invest \$2 million in exploration expenditures and deliver a feasibility study by the end of 2011, or incur additional exploration expenditures totaling $\$ 5.5$ million and deliver a feasibility study by the end of 2015. Drilling is planned in 2008.

Midas Resources Ltd. withdrew from the Uncle Sam project prior to the 2007 field season.

At the Tanacross Project, Full Metal staked seven claim groups covering syngenetic massive sulfide and copper-gold-molybdenum porphyry targets. Full Metal completed mapping and soil sampling surveys on these targets.

Millrock Resources Inc. staked three blocks of state mining claims in the Fortymile mining district. Millrock is targeting disseminated and vein-style intrusion-related 
lode gold deposits in the project area. The claim blocks are strategically located adjacent to $\sim 135$-million-yearold felsic to intermediate intrusions with downstream gold placers.

Linux Gold Corp. optioned the Lost Dog claims on Ester Dome in the Fairbanks area and conducted exploration for lode gold mineralization.

Placer exploration continued on a small scale across the region. Prospecting was conducted by Bed Rock Enterprises, Hard Head Mining dug holes and trenches on Montana Creek, Bill Lance prospected in the Jack Wade Creek area, and Rolling Stone Inc. staked and sampled mining claims (fig. 13).

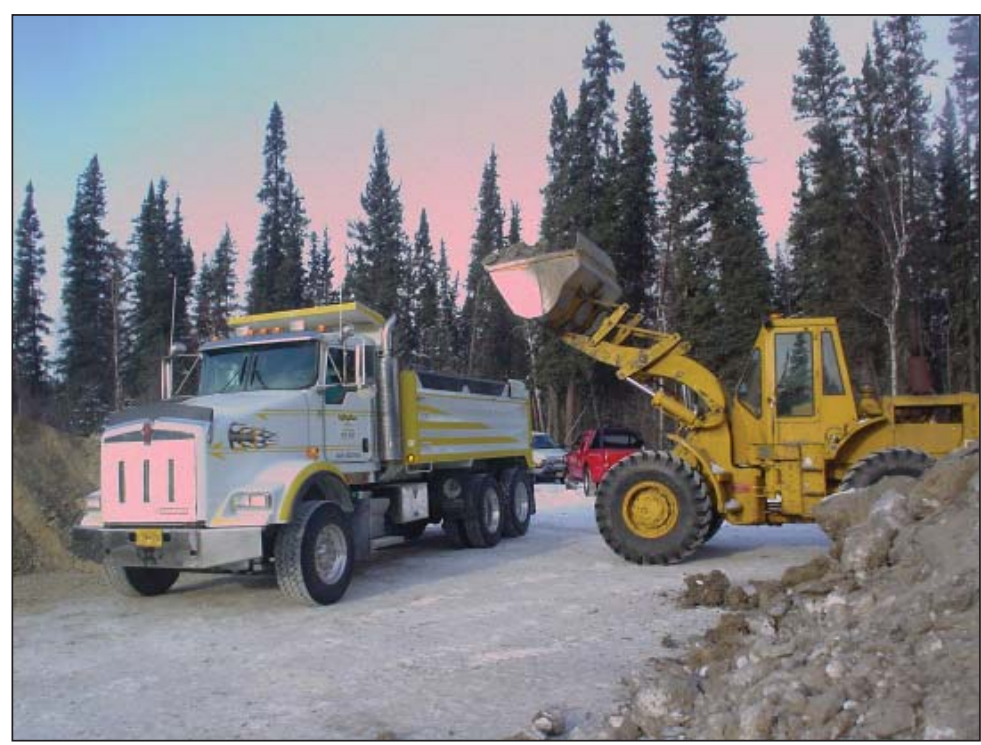

Figure 13. Rolling Stone Inc.'s sand and gravel operation. The company conducted some exploration during 2007. Photo courtesy of Rolling Stone Inc.

\section{SOUTHCENTRAL REGION}

Geoinformatics Exploration Inc. announced the initial independent mineral resource estimate at its Whistler project near Rainy Pass. The indicated resource is estimated at 33.06 million tons grading 0.025 ounces of gold per ton, 0.072 ounces of silver per ton, and 0.24 percent copper, containing 840,000 ounces of gold, 2.37 million ounces of silver, and 159 million pounds of copper. The inferred resource is estimated at 147.7 million tons grading 0.019 ounces of gold per ton, 0.064 ounces of silver per ton, and 0.20 percent copper, containing 2.74 million ounces of gold, 9.44 million ounces of silver, and 573 million pounds of copper. In 2007, Geoinformatics completed seven drill holes (10,900 feet) on the Whistler Zone. Drill results include the identification of a new copper-rich area within the Whistler Zone that is interpreted to be a new high-grade zone or a western extension of the Main Zone. Drillhole WH-07-02 successfully established a western extension to the Whistler Zone and intersected a new high-grade adjunct to the Main Zone, recording some of the highest grades seen to date at Whistler, including 433 feet grading 0.016 ounces of gold per ton, 0.16 percent copper, 0.021 ounces of silver per ton, and 154 feet grading 0.047 ounces of gold per ton, 0.40 percent copper, and 0.060 ounces of silver per ton. Drillhole WH-07-07, at the northern end of the Main Zone, included a 50.8-foot intersection grading 0.015 ounces of gold per ton and 0.55 percent copper, and a 531.5-foot intersection grading 0.013 ounces of gold per ton and 0.21 percent copper.

International Tower Hill Mines completed a preliminary exploration program on the South Estelle project, held under option from Hidefield Gold PLC. High-grade gold mineralization was found at the Shoeshine, Train, and Portage prospects in north-northwest-trending, steeply dipping veins. The Shoeshine vein system, generally hosted in the Mount Estelle monzonite batholith, has a currently defined strike length in excess of 2,300 feet, with numerous high-grade chip samples, including one quartz-sulfide vein sample with 6.94 ounces of gold per ton and 11.35 ounces of silver per ton, and a 1-foot-wide channel sample with 3.67 ounces of gold per ton.

Nevada Star Resource Corp. joined Pure Nickel Inc. in a reverse takeover in March. Pure Nickel continued exploration in the MAN area focused on the Alpha and Beta complexes with a program consisting of a 2,067 line-mile, helicopter-borne versatile time-domain electromagnetic (VTEM) and magnetometer survey by Geotech Ltd., with 180-foot terrain clearance for the VTEM system and 246-foot terrain clearance for the magnetic sensor. A soil-sampling program, completed by Mineral Exploration Services of Reno, over the Alpha and Beta complexes resulted in 2,282 samples collected at 164-foot spacing along north-south-aligned lines spaced 164 or 328 feet apart on a northwest-trending grid. Soil sample results confirmed and better defined previously identified geochemical anomalies, and elevated nickel and copper soil sample values were coincident with west-northwest-striking exposures of ultramafic rock layers within the complexes. Thirteen targets were drilled by Peak Exploration Ltd. on the Alpha Complex in 15 holes totaling 11,018 feet. Drilling intersected disseminated to small bleb sulfides within picritic to gabbroic rocks in all the holes over a 12-mile strike length. 
The disseminated sulfide mineralization occurs over thick intervals, including 254 feet in hole MANPNI-07001, 984 feet in hole MANPNI-07-006, 663 feet in hole MANPNI-07-007, 1,069 feet in hole MANPNI-07-008, and 918 feet in hole MANPNI-07-010. Geochemical results include an average of 0.26 percent nickel, 0.12 percent copper, 139 parts per billion palladium, and 62 parts per billion platinum from ultramafic rocks with disseminated sulfides over a 260 -foot interval in drill hole MAN-PNI-001. Other drilling results include 70 feet of disseminated sulfides in serpentinized dunite in hole MAN-PNI-07-003 that assayed 0.26 percent nickel, 0.05 percent copper, $61 \mathrm{ppb}$ platinum, $71 \mathrm{ppb}$ palladium and $13 \mathrm{ppb}$ gold; serpentinized peridotite and dunite interlayers in hole MAN-PNI-07-006 with a 36.7-foot interval averaging 0.22 percent nickel and 0.06 percent nickel; a 177-foot interval of interlayered and altered peridotite and dunite in hole MAN-PNI-07-007 that averaged 0.20 percent nickel, 0.02 percent copper, and trace amounts of platinum, palladium, and gold; a 216-foot interval of serpentinized dunite in hole MAN-PNI-07011A averaged 0.21 percent nickel, and trace amounts of copper, platinum, and palladium; and a 135-foot interval of interlayered serpentinized peridotite and dunite in hole MAN-PNI-07-009 averaged 0.21 percent nickel, and trace amounts of copper, platinum, and palladium. Pure Nickel interprets the drill results to indicate that targeted electromagnetic conductors can be attributed to sulfide mineralization within the Alpha ultramaficmafic complex. In addition, drill hole correlation and surface mapping by Pure Nickel suggest that the sulfide mineralization in the Alpha Complex is stratiform, and has a mile-scale lateral continuity. For example, a 600- to 1,000 -foot interval of 0.45 percent disseminated sulfides can be traced for 1.62 miles between holes MAN-PNI07-006 and MAN-PNI-07-007.

Full Metal Minerals dropped their exploration permit to explore for coal on Alaska Mental Health Trust Authority land near Chickaloon. The land had previously been mined for high-quality coking-grade coal and may contain up to 30 million tons of coal. Local residents had protested any exploration work, including Full Metal's plan for a drilling and trenching program, in the area.

Full Metal Minerals tested three of four known fault blocks at the Lucky Shot property during a 45,000-foot drill program, extending continuous gold mineralization to more than 1.5 miles along strike and 2,300 feet downdip. Hole C07-92 from the Murphy zone returned 3.2 feet grading 1.59 ounces of gold per ton. Best intercepts from holes C07-105, 110, and 112 at the near-surface Coleman zone returned 3 feet grading 0.505 ounces of gold per ton, 1.6 feet grading 2.09 ounces of gold per ton and 1.6 feet grading 0.621 ounces of gold per ton, respectively. Hole C07-143 from the Lucky Shot zone returned 1.6 feet grading 2.25 ounces of gold per ton. Full Metal began metallurgical testing, permitting, and feasibility studies in 2007 and plans to complete feasibility studies in 2008 as well as begin underground exploration and rehabilitation.

Hemis Corp. acquired Aspen Exploration Corp.'s Anchor Point gold project in the Cook Inlet area. Under the terms of the agreement, Aspen was paid $\$ 50,000$ at signing and will be paid this amount on each anniversary of the agreement in order to maintain Hemis's interest in the project. Aspen is entitled to a 5 percent production royalty, which may be taken in kind or in cash. Earthfield Technologies of Houston was contracted to process newer aeromagnetic data covering lower Cook Inlet. A preliminary oceanographic survey indicated that the water depth was less than 35 feet in many of the areas of interest. A geophysical survey consisting of a fathometer, side-scan sonar, and a sparker survey was conducted by Watson Geophysics. The goal of the sparker survey was to image the shallow subsurface sediments. Concurrently, a shallow coring program was conducted by Kinnetic Labs using a Vibracore ${ }^{\circledR}$ drill rig. Ultimately, cores were recovered from 11 of the 15 target areas, with gravel encountered in nine holes.

Pacific North West Capital Corp. sampled outcrops and mapped nickel, copper, and platinum-group-element mineralization hosted in dunite and lherzolite within the Tonsina Ultramafic Complex on the Tonsina property, centered on Sheep Hill in the northeastern Chugach Mountains. The Tonsina project is part of a reconnaissance agreement with Stillwater Mining Co. Sulfide-bearing outcrop grab samples contain up to 0.97 percent nickel and 0.58 percent copper. Petrographic examination revealed the presence of widespread pentlandite together with millerite and lesser covellite in select mineralized samples. Chip channel samples of chromite and sulfide-bearing outcrop contain up to 0.025 ounces of platinum per ton and 0.032 ounces of palladium per ton over a 6.4 -foot interval.

Full Metal completed surface sampling and mapping at its Goldigger Project, located in the Talkeetna Mountains. Targets include multiple occurrences of epithermal gold-silver mineralization. Full Metal gave notice that it was dropping the option agreement for the property.

The State of Alaska, through DGGS, funded and acquired airborne magnetic and electromagnetic geophysical surveys for 180 square miles of the 715square-mile Styx River survey area in the northeastern Lime Hills and northwestern Tyonek quadrangles. The surveys were conducted by Fugro Airborne Surveys Corp. and managed by Stevens Exploration Management Corp. Funding was provided by the Alaska State Legislature as part of the DGGS Airborne Geophysical/ Geological Mineral Inventory (AGGMI) program. 
Diamond Gold Corp. continued to evaluate their properties in the Yenlo Hills and Kahiltna River area for diamond and gemstone potential. Gold Cord Development Corp. continued an exploration drift at the Gold Cord Mine and also conducted a small core drilling program.

Minor amounts of placer exploration occurred across the region. Most activity was in the road-accessible areas of the Petersville and parts of the Valdez Creek and Yentna mining districts.

\section{SOUTHWESTERN REGION}

Northern Dynasty Minerals Ltd.'s Pebble property, near Iliamna in southwestern Alaska, was Alaska's largest exploration project in 2007. Recent discoveries of copper, gold, and molybdenum metal resources at the Pebble property have outlined a possible open-pit resource at the Pebble West Deposit and a likely underground resource at the Pebble East Deposit. Exploration in 2007 concentrated on drilling the Pebble East deposit. Announced metal resources for the Pebble deposit total 74 billion pounds of copper, 87 million ounces of gold, and more than 5.2 billion pounds of molybdenum, making this the second-largest "porphyry copper" deposit in the world. During 2007, a wholly owned subsidiary of Anglo American PLC became a 50 percent partner on the Pebble Project, with a total stage investment commitment of $\$ 1.425$ billion, including spending \$125 million to complete the prefeasibility study and another $\$ 325$ million to complete a feasibility study. The companies formed the Pebble Partnership to continue the project forward.

Drilling continued in 2007 with up to nine drill rigs; 157,000 feet of core drilling was completed in 36 holes. Core drilling was contracted to American Recon Inc. and Boart Longyear Ltd. Geotechnical drilling was contracted to Foundex Pacific Inc. Drilling continued to intersect long intervals of higher grade copper-gold-molybdenum mineralization and drill results established a very high level of deposit continuity in the Pebble East deposit. Hole 7359 intersected 2,228 feet grading 1.42 percent copper equivalent comprising 0.92 percent copper, 0.015 ounces of gold per ton, and 0.035 percent molybdenum; hole 7374 intersected 2,449 feet grading 1.19 percent copper equivalent comprising 0.61 percent copper, 0.012 ounces of gold per ton, and 0.056 percent molybdenum; and hole 7386 intersected 2,570 feet grading 1.17 percent copper equivalent comprising 0.66 percent copper, 0.011 ounces of gold per ton, and 0.049 percent molybdenum. Other drill results include hole 7378 with a 1,846-foot intersection grading 1.45 percent copper equivalent comprising 0.91 percent copper, 0.020 ounces of gold per ton, and 0.033 percent molybdenum; hole 7379 with a 2,560-foot intersection grading 1.17 percent copper equivalent comprising 0.74 percent copper, 0.009 ounces of gold per ton, and 0.040 percent molybdenum; hole 7381 with a 2,111-foot intersection grading 1.37 percent copper equivalent comprising 0.77 percent copper, 0.019 ounces of gold per ton, and 0.037 percent molybdenum; hole 7384 with a 1,186 -foot intersection grading 1.27 percent copper equivalent comprising 0.74 percent copper, 0.019 ounces of gold per ton, and 0.026 percent molybdenum; and hole 7387 with a 1,961-foot intersection grading 1.44 percent copper equivalent comprising 0.89 percent copper, 0.020 ounces of gold per ton, and 0.026 percent molybdenum.

Preliminary mining engineering activities designed to assess Pebble East as a high-volume, low-cost underground mine continued through 2007 at the Pebble Project. Pre-feasibility-level metallurgical and comminution testwork on Pebble East mineralization continued in 2007. Environmental and socioeconomic baseline data studies continued and expanded the geographic scope of investigations to support Pebble East planning. This work was undertaken by more than 45 independent consulting firms. The Pebble Partnership facilitated 430 meetings with project stakeholders throughout Alaska. The 2007 workforce totaled 1003 employees, including 544 Alaskans. More than 140 local people from more than 16 communities in the Bristol Bay area were employed at the Pebble project last year, and significant expenditures were made on local goods, services, and salaries.

NovaGold Resources Inc. reported results from 498,688 feet of drilling completed in 2006 and 2007 at the Donlin Creek gold deposit. The exploration averaged 220 feet of mineralization per hole, grading 0.105 ounces of gold per ton. In excess of 230,000 feet of drilling was completed in 2007 by Barrick Gold Corp. The two best drill intersections during 2007 were hole DH-1556 with 981 feet grading 0.153 ounces of gold per ton and hole DH-1564 with 1,010 feet grading 0.134 ounces of gold per ton; both holes are in the East Acma area and extend mineralization beyond the current pit model boundaries.

Donlin Creek drill results from 2007 in the Acma area are: hole DC07-1499 with 11 mineralized intervals totaling 718.5 feet grading 0.092 ounces of gold per ton; hole DC07-1515 with nine mineralized intervals totaling 354 feet grading 0.124 ounces of gold per ton; hole DC071541 with eight mineralized intervals totaling 564 feet grading 0.148 ounces of gold per ton; hole DC07-1548 with six mineralized intervals totaling 328 feet grading 0.145 ounces of gold per ton; hole DC07-1550 with six mineralized intervals totaling 367.4 feet grading 0.210 ounces of gold per ton; hole DC07-1575 with eight mineralized intervals totaling 479 feet grading 0.119 ounces of gold per ton; hole DC07-1589 with ten mineralized 
intervals totaling 452.8 feet grading 0.118 ounces of gold per ton; hole DC07-1593 with eight mineralized intervals totaling 351 feet grading 0.140 ounces of gold per ton; hole DC07-1595 with two mineralized intervals totaling 59 feet grading 0.326 ounces of gold per ton; hole DC07-1598 with six mineralized intervals totaling 377.3 feet grading 0.173 ounces of gold per ton; and hole DC07-1639 with 11 mineralized intervals totaling 623.4 feet grading 0.119 ounces of gold per ton.

Donlin Creek drill results from the East Acma area are: DC07-1649 with nine mineralized intervals totaling 236.2 feet grading 0.098 ounces of gold per ton; hole DC07-1663 with 13 mineralized intervals totaling 623.4 feet grading 0.143 ounces of gold per ton; and hole DC07-1667 with 18 mineralized intervals totaling 876 feet grading 0.094 ounces of gold per ton. These drill hole intercepts continue to demonstrate excellent gold grades in the East Acma target area and expand mineralization along the shallowly plunging Donlin anticline, which contains the rhyodacite porphyry intrusive bodies that host the majority of the Donlin Creek mineralization. Similar geology projects roughly 3,000 to 4,000 feet further to the east and south from this new East Acma drilling, with the potential to add substantially to the overall mineral resource.

NovaGold Resources announced in early 2008 that the measured and indicated resource for the Donlin Creek project increased by 77 percent to 29.4 million ounces of gold, with a gold grade of 0.072 ounces per ton, successfully converting a majority of the inferred resources to the measured and indicated category. New inferred gold resources are 3.46 million ounces, with a gold grade of 0.067 ounces per ton. The new resource estimate includes an additional 443,000 feet of drilling from 359 holes, incorporating all of the 2006 drill program and roughly 72 percent of the 2007 drill program at Donlin Creek. The remaining approximately 65,620 feet of 2007 drill results will be incorporated into future modeling. The resource was constrained within a conceptual pit based on a gold price of $\$ 650$ per ounce and using recent estimates of mining, geotechnical, and metallurgical parameters. Environmental baseline data collection, in addition to a wide range of engineering work, was completed in support of the feasibility study. NovaGold and Barrick Gold Corp. ended a bitter, year-long battle in November when the two companies agreed to advance the project as equal partners. The Donlin Creek project is managed by a new limited-liability company, the Donlin Creek LLC, which is jointly owned by NovaGold and Barrick Gold Corp. on a 50/50 basis. Work in the first half of 2008 will focus on completing a series of optimizing studies for power, logistics, processing, and production levels, and will integrate all data from the 2007 program into a final feasibility study.
NovaGold Resources also conducted exploration on four claim blocks totaling 583 Alaska state mining claims 20 to 40 miles south of Aniak near the Aniak River that were staked due to indication of clay alteration on ASTER imagery, anomalous reconnaissance stream silt or rock geochemical results, and favorable geology for a Donlin Creek type gold deposit. NovaGold collected 104 rock, soil, and silt samples during 2007 on the 6-mile-long Ash claim block and results include extensive arsenic anomalies with some low-level anomalous gold, including rhyodacite dike rock samples with up to 57 parts per billion gold. During the 2003 and 2007 field seasons, NovaGold collected 340 rock samples, 134 soil samples, and 287 stream-sediment samples on the large Timber claim block in an area where rhyolite dikes and quartz monzonite plugs intrude Cretaceous shale and volcanic rocks. Sampling returned gold values from rocks up to $1.02 \mathrm{ppm}$. The best gold concentrations were from areas of quartz veining in rhyolite, rhyodacite, and siltstone in the central and south-central part of the Timber claims. Geochemical results from 121 samples collected during 2003 and 2007 on the Kipchuk claim block include a few detectable gold values up to $81 \mathrm{ppb}$ and some anomalous arsenic, mercury, bismuth, and antimony results associated with clay alteration along northeast-trending structural zones. NovaGold collected 202 rock and soil samples in 2003 and 2007 from rhyolite domes intruding Cretaceous Kuskokwim Group sedimentary rocks on the Cone claim block. Gold values reach $1.3 \mathrm{ppm}$ with numerous samples in the 0.5 to 0.75 ppm range. High gold, arsenic, and antimony values are associated with northeast-trending low sulfidation quartz veining in the rhyolite dome complex in a zone approximately 300 feet across.

International Tower Hill holds a 60 percent jointventure interest in the Terra project, with the balance held by AngloGold Ashanti (U.S.A.) Exploration Inc. Drilling, including 12 holes in 2007 at the Ben Zone, three holes at the Ice Vein area, and other exploration work, define a 3-mile-long, high-grade gold-quartz epithermal vein system from the Fish Creek area to the north, through the Ben Vein area, to the Ice area 2 miles to the south. Significant drilling results in 2007 from the Ben Vein include 3.8 feet grading 0.356 ounces of gold per ton in hole TR07-21; 1.61 feet grading 1.781 ounces of gold per ton in hole TR07-22; 5.61 feet grading 0.604 ounces of gold per ton in hole TR07-26; 8.14 feet grading 0.821 ounces of gold per ton in hole TR07-27; and 7.07 feet grading 0.488 ounces of gold per ton in hole TR07-28. All three holes drilled at the Ice target intersected a previously unknown high-grade gold vein zone. Drillhole TR-07-29 intersected 2.2 feet grading 0.197 ounces of gold per ton and 7.94 feet grading 0.278 ounces of gold per ton; hole TR-07-30 intersected 16.57 
feet grading 0.115 ounces of gold per ton and 5.35 feet grading 0.107 ounces of gold per ton; and hole TR-0732 intersected 1.57 feet grading 0.66 ounces of gold per ton. An independent study by Mineral Resource Services Inc. and Giroux Consultants Ltd. based on 20 drill holes determined an initial inferred resource estimate of 168,000 ounces of gold and 318,000 ounces of silver at a cutoff grade of 0.146 ounces of gold per ton, having an average grade of 0.356 ounces of gold per ton, and 0.674 ounces of silver per ton over an average 7.55 -foot width. Gold in the Ben Vein deposit occurs as native gold and electrum with associated silver minerals. Initial gold characterization studies indicate good gravity recovery results (79 percent as native gold, 10 percent as gold in sulfide concentrate). International Tower Hill provided notice on November 5 to AngloGold Ashanti (U.S.A.) Exploration Inc. that it had incurred sufficient expenditures to vest its 60 percent ownership in the project. AngloGold had 90 days to decide whether or not to exercise its right to earn back an additional 20 percent interest in the project by incurring $\$ 4$ million in expenditures over the next 2 years.

International Tower Hill also identified a 5-mile-long belt of precious-metal-rich massive sulfide mineralization related to Cretaceous intrusive rocks in the region. The BMP project targets copper-silver mineralization hosted in Paleozoic sedimentary rocks in the Farewell district. A very unusual style of skarn mineralization was discovered at the 6120 Prospect where the average grade of 22 outcrop samples collected was 2.1 percent copper, 0.09 ounces of gold per ton, 0.87 ounces of silver per ton, 0.14 percent nickel, and 0.06 percent cobalt.

Andover Ventures has several properties in the Iliamna Lake region under option from Bristol Bay Native Corp. and held in a 50 percent joint-venture with Alix Resources Corp. (formerly NPN Investment Group). Historic drill core from the Kemuk iron prospect was re-logged and analyzed during the spring of 2007, but no significant platinum-group-element mineralized zones were detected. Andover conducted first-pass geological and geochemical examination at the Samuelsen, Chilikat West, and Chilikat East prospects. A total of 542 samples were taken from the properties.

Andover Ventures optioned a 50 percent interest in the KUY, Fog, and Kamishak properties to Alix Resources Corp. Four core holes totaling 2,602 feet were drilled at KUY in August with holes KUY-08-07 and KUY-09-07 encountering significant clay (kaolinite?) alteration in dacitic rocks with up to 15 percent pyrite with disseminated chalcopyrite and veinlets. Induced polarization (IP) and resistivity surveys at the Kamishak property in 2007 detected significant anomalous zones outside of previous drilled areas. No work was completed on the Fog Lake property in 2007.

Gold Crest Mines Inc. completed a total of 3,102 feet of diamond drilling in six drill holes at the Kisa property (fig. 14). Broad zones of weak to moderate alteration and low-grade mineralization in sedimentary

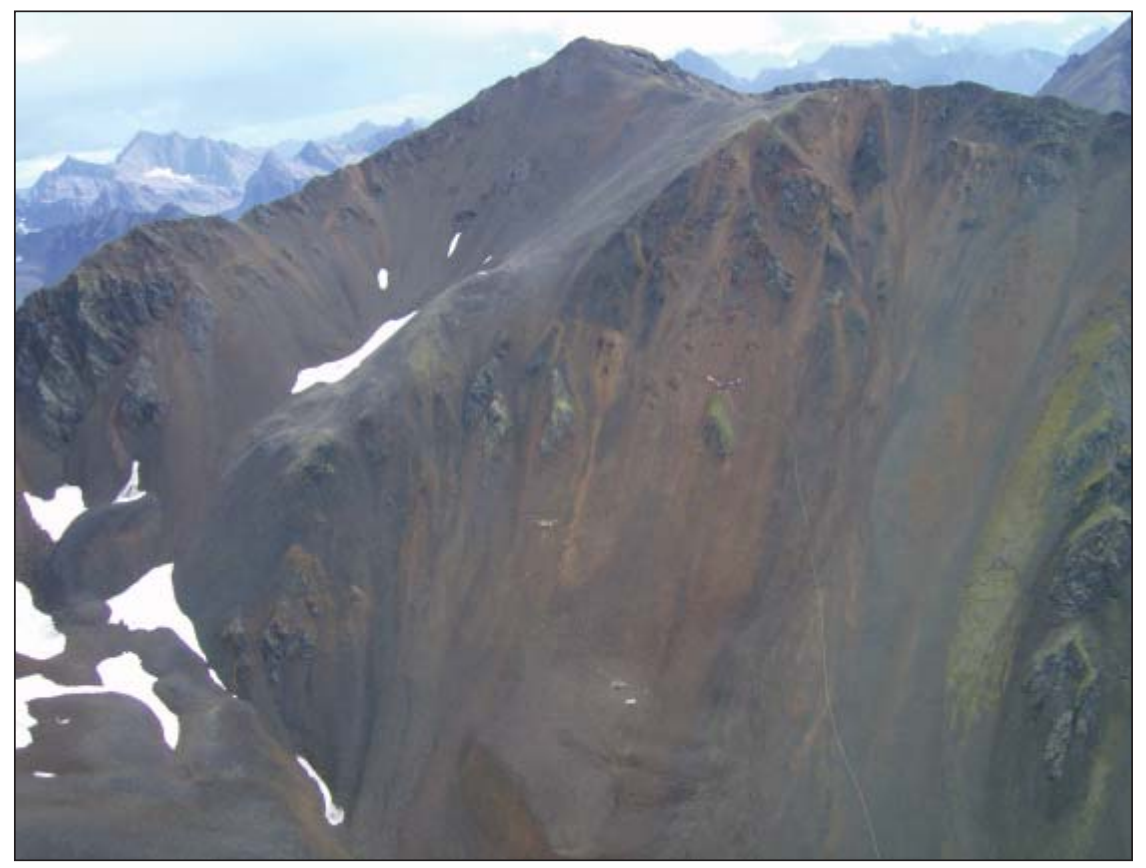

Figure 14. Drilling on precipitous terrain at Gold Crest Mines Inc. 's Kisa property. Note the drill rig and waterline just right of center in the photo. Photo provided by Gold Crest Mines Inc. 
and intrusive lithologies were observed in holes K07-2 through K07-6. A 378.5-foot intercept averaged 0.02 ounces of gold per ton, with an included interval of 0.252 ounces of gold per ton.

Gold Crest Mines identified new mineralized dikes through mapping, sampling, and about 2,100 square miles of airborne geophysical work. The Luna claims were staked west of the Kisa claim block, as well as four additional claim blocks 45 miles northeast of the Kisa prospect. Gold mineralization is hosted in calcareous siltstone, chert, and tuffaceous sedimentary rocks, as well as in porphyritic intrusive rocks.

Pacific North West Capital Corp., with approval from Calista Corp., entered into a joint-venture agreement with Stillwater Mining Co. on the Goodnews platinum project. Stillwater can earn a 50 percent interest in the project by spending $\$ 4$ million by December 31, 2010, and may elect to increase its interest to 60 percent by incurring an additional $\$ 8$ million in exploration expenditures within an additional 2-year period or upon completion of a feasibility study, whichever occurs first. Stillwater may increase its interest to 65 percent by arranging for 100 percent of the project financing required to place the property into commercial production within an additional 3 years. Pacific North West collected 651 rock outcrop grab samples, 26 coarse wash pan concentrate samples, and 110 auger soil samples during 2007. Rock samples of chromite-bearing dunite assayed up to 0.067 ounces of platinum per ton at the Last Chance prospect at the head of Dowry Creek on Red Mountain. Magnetite-clinopyroxene veins cutting dunite are also present but have lower platinum/palladium ratios. The bedrock platinum anomaly at the Last Chance prospect measures 2,500 feet by 575 feet, aligned lengthwise in a north-south direction with 164 feet of vertical exposure. A 650 -foot by 115 -foot tear-shaped anomaly, with greater than 50 parts per billion platinum was defined by an auger soil sampling program at the Susie West prospect. Soil sample results of soils derived from clinopyroxene-rich rocks ranged up to 432 parts per billion platinum. Rock sample results from wehrlite outcrops on the southwestern ridge of Susie Mountain at the Rock Mite prospect expanded surface mineralization. Seven of 20 rock samples had assay results greater than 100 parts per billion platinum, with the highest result being 603 parts per billion ( 0.018 ounces of platinum per ton) platinum.

Full Metal Minerals and Highbury Projects Inc. announced a gold discovery at the Moore Creek property. Three new discoveries (Spring Zone, Troy Zone, and Broken Shovel Zone) were made during a two-phase trenching program, with the best result of 0.260 ounces of gold per ton over 36 feet at the Spring Zone. Gold mineralization is hosted in steeply dipping sheeted quartz veins that range from 0.4 to 4 inches thick, and are hosted within pervasive tourmaline altered and silicified monzonite intrusive rock. Forty rock samples were taken from the seven trenches in the Spring Zone. Quartz veins at the Troy Zone, immediately north of the Spring Zone, were tested with 177 bedrock and colluvium samples from trenches. One quartz vein in the Troy Zone was traced for more than 160 feet and sampled in three locations, with analytical results of 2.581 ounces of gold per ton, 1.05 ounces of gold per ton, and a 10-foot channel sample of 0.222 ounces of gold per ton. Three trenches were completed at the Broken Shovel prospect, about 600 feet north of the Troy Zone, and 12 rock samples were collected. The best sample result was 0.112 ounces of gold per ton, 32.229 ounces of silver per ton, and highly anomalous bismuth, arsenic, and mercury levels.

Millrock Resources Inc. optioned and agreed to a joint venture with Liberty Star Uranium and Metals Corp. at the Bonanza Hills property. Millrock will have the option to secure a 60 percent interest in the project by expending a total of $\$ 3.5$ million and by issuing a total of 1 million shares of Millrock over a 4-year period. Millrock also staked 124 state mining claims on another property with similar geologic attributes about 20 miles to the south of the Bonanza Hills property and centered on an anomalous airborne magnetic feature. Anglo American Exploration Inc. staked a much larger area abutting and to the east of the claim group.

Full Metal Minerals signed an option agreement with Freeport-McMoRan Copper and Gold Inc. under which Freeport can earn a 60 percent interest in the Pebble South property. The agreement includes funding $\$ 1.8$ million in exploration expenditures over 4 years, and a minimum of 6,400 feet of drilling in the first year. Freeport can earn an additional 20 percent interest by funding all expenditures related to the property through and including a decision to build a mine with a capacity of at least 30,000 tons per day of ore.

During the spring and summer of 2007, Full Metal staked multiple copper-gold-molybdenum porphyry targets in Alaska, and conducted reconnaissance-scale mapping and sampling programs. Full Metal Minerals subsequently signed an option agreement with BHP Mineral Services Co., a subsidiary of BHP Billiton, in which BHP Billiton can acquire up to an 80 percent interest in Full Metal's six copper-gold-molybdenum porphyry targets in Alaska. BHP Billiton can earn an initial 60 percent interest in the properties by incurring $\$ 2.5$ million in expenditures over 36 months, and acquire a further 20 percent interest by incurring an additional $\$ 3.5$ million within 36 months of exercising the initial option.

Goldmark Minerals Ltd. entered into an agreement to acquire Geocom Resources Inc.'s interest in the Il- 
iamna project, previously explored under a joint-venture agreement by TNR Gold Corp. and Geocom Resources Inc. Goldmark would purchase a 52.5 percent interest in the $\mathrm{H}$ claim section and a 38.5 percent interest in the D claim section of the copper porphyry Iliamna project. The acquisition was under review at year's end.

Barrick Gold Corp. explored for intrusion-related gold on the Julian Creek property. Newmont Mining Corp. conducted regional gold exploration, including geochemical and geophysical surveys, across southwestern Alaska.

Ray Hanson recently sold all of his patented ground and federal mining claims in the Salmon River drainage area and on the flanks of Red Mountain in the Goodnews Bay mining district to XS Platinum Ltd., an offshore venture-capital firm based in the U.K., with major business connections in Australia. Hanson retained a 10 percent net smelter return.

TNR Gold Corp. mapped and sampled at the Shotgun property to identify drill targets along extensions of the Winchester zone.

Lyman Resources conducted some exploration work in the Donlin Creek area during their placer mining activities (fig. 15). Placer gold exploration was also conducted in the Nyac mining district.

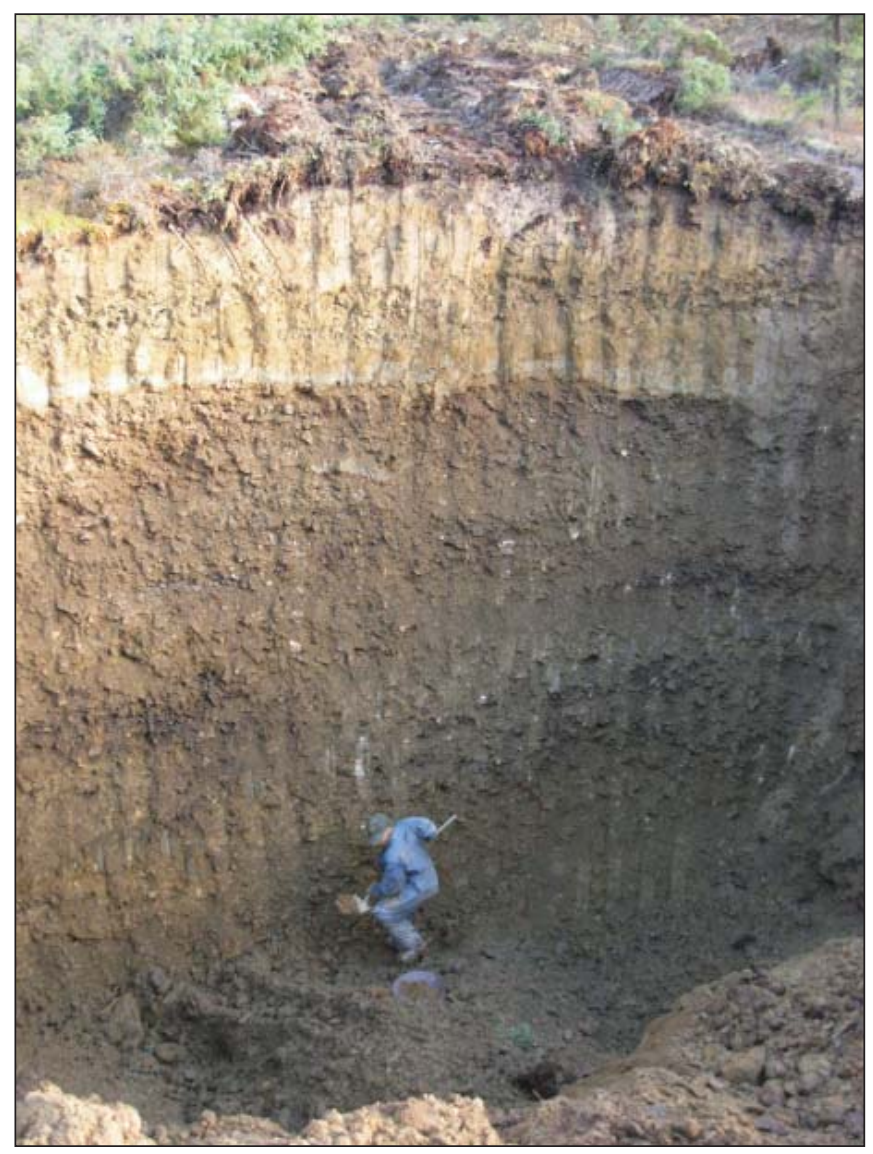

\section{ALASKA PENINSULA}

Metallica Resources Inc. conducted mapping, geochemical sampling, and water sampling at the Bee Creek and the Kawisgag prospects.

\section{SOUTHEASTERN REGION}

Greens Creek Mining Co. continued surface and underground exploration programs at Greens Creek Mine. Most of the underground exploration focused on the silver-rich 5250 North Extension zone and the West Gallagher zone. In the 5250 zone, a hole was drilled 1,000 feet above and along strike of the known reserve and resource and intersected silver grades of 30 ounces per ton with 18 percent zinc and lead. The surface exploration program conducted in 2007 consisted of 17,540 feet of drilling in 14 holes and focused on identifying resource extensions in proximity to the current Greens Creek infrastructure, as well as identifying "mine horizon" rocks and defining target areas with soil geochemical sampling, geologic mapping, and geophysical surveys elsewhere on the property that could represent a whole new deposit. Drilling included work at the Little Sore, Upper Gallagher, and West Gallagher prospects. Three holes drilled from the West Gallagher East drillpad successfully intersected multiple fold repeats of the mine contact along 1,200 feet of strike length and show that there are still significant areas east and west of the Gallagher Fault that remain prospective. A new surface drill hole from the North Big Sore drillpad successfully intersected the mine contact zone intersected last year. Although not mineralized, these results are significant because for the first time an altered mine contact zone has been intersected to the east of the East Ore trend. These drilling results open up a new area to explore for mine extensions in close proximity to underground infrastructure.

Niblack Mining Corp. continued surface exploration on the Niblack volcanogenic massive sulfide property. Initial drilling during the 2007 surface program focused on expanding the South Lookout Zone, which is several hundred feet south and parallel to massive sulfide of the main Lookout Zone trend. The surface exploration program plan included at least 12,500 feet of diamond drilling in 17 holes. Drill hole LO-195 intersected 21.3 feet of massive sulfide grading 0.065 ounces of gold per ton, 1.546 ounces of silver per ton, 6.16 per-

Figure 15. Spencer Lyman collecting dirt and gravel to pan from a prospect hole near Crooked Creek. Photo courtesy of Lyman Resources Alaska Inc. 
cent copper, and 8.19 percent zinc, within a wider zone grading 0.040 ounces of gold per ton, 1 ounce of silver per ton, 3.56 percent copper, and 3.16 percent zinc over 61.3 feet. A second zone of high-grade massive sulfide intersected in hole LO-195 graded 0.268 ounces of gold per ton, 3.850 ounces of silver per ton, 7.11 percent copper, and 6.80 percent zinc over 10.3 feet. A total of ten holes were drilled in the South Lookout Zone in 2006 and 2007. The average of all 2006 and 2007 mineralized intersections is 27.3 feet grading 0.086 ounces of gold per ton, 1.342 ounces of silver per ton, 2.58 percent copper, and 3.64 percent zinc. Additional drilling in 2007 focused on other targets on the property including the Dama Zone and the Trio Zone. Drilling at the Trio Zone included drill hole LO-206, which intersected 34.9 feet of massive sulfide and stockwork mineralization grading 0.098 ounces of gold per ton, 1.429 ounces of silver per ton, 3.46 percent copper, and 4.49 percent zinc, and drill hole LO-207, testing the sulfide horizon 130 feet down dip of LO-206, which intersected 18.6 feet grading 0.118 ounces of gold per ton, 1.604 ounces of silver per ton, 2.52 percent copper, and 5.31 percent zinc. Drilling at the Dama Zone in hole LO-203 intersected stockwork mineralization grading 0.54 percent copper over 60 feet, and 1.1 feet of massive sulfide grading 0.064 ounces of gold per ton, 2.071 ounces of silver per ton, 10.8 percent copper, and 8.18 percent zinc.

Following a comprehensive permit review process, Niblack Mining Corp. began an underground exploration program in September 2007 (fig. 16). Niblack planned to drive an adit approximately 6,000 feet to provide access for 30,000 feet of underground drilling at the Mammoth Zone of the Niblack property during late 2007 and through 2008. The new access would allow the company to test more than 1.2 miles of massive-sulfide-favorable stratigraphy and provide for year-round exploration. Niblack Mining selected J.S. Redpath Corp. as the underground development contractor at the Niblack project. Underground drilling began in mid-November and three holes were completed by year's end. Approximately 680 feet of adit had been completed by year's end.
Niblack Mining staked 45 additional federal lode mining claims surrounding the core Niblack claim block. The Ruby Tuesday volcanogenic massive sulfide prospect, 10.5 miles southeast of the Niblack property, was also staked with 120 federal mining claims. The property includes two major zinc-copper-gold-silver showings. Niblack Mining also staked a new copperzinc-silver-gold volcanogenic massive sulfide property, the Cayenne property, on Prince of Wales Island. The Cayenne property includes the former-producing Khayyam and Stumble-On deposits. Mineralization at the Cayenne property consists of at least six near-vertical stratiform massive and semi-massive sulfide lenses of coarse-grained pyrite, chalcopyrite, sphalerite, and pyrrhotite. Sulfide lenses are elongate and are as much as 20 feet thick and 550 feet long. Work completed on the Cayenne property in 2007 included reconnaissance geologic work, limited rock sampling, and a CSAMT geophysical survey. The CSAMT survey was completed on four survey lines for a total of 1.5 line miles. Multiple strong conductors were identified at depth, some of which correlate well with known sulfide lenses mined near surface, while others may represent new sulfide lenses. Chip sampling across a 6.5 -foot-wide surface outcrop of massive sulfide yielded 9.66 percent zinc, 0.88 percent copper, 0.181 ounces of silver per ton, and 0.009 ounces of gold per ton. Sampling of boulders from the mine dump assayed up to 14.6 percent zinc, 15.4 percent copper, 3.179 ounces of silver per ton, and 0.167 ounces of gold per ton.

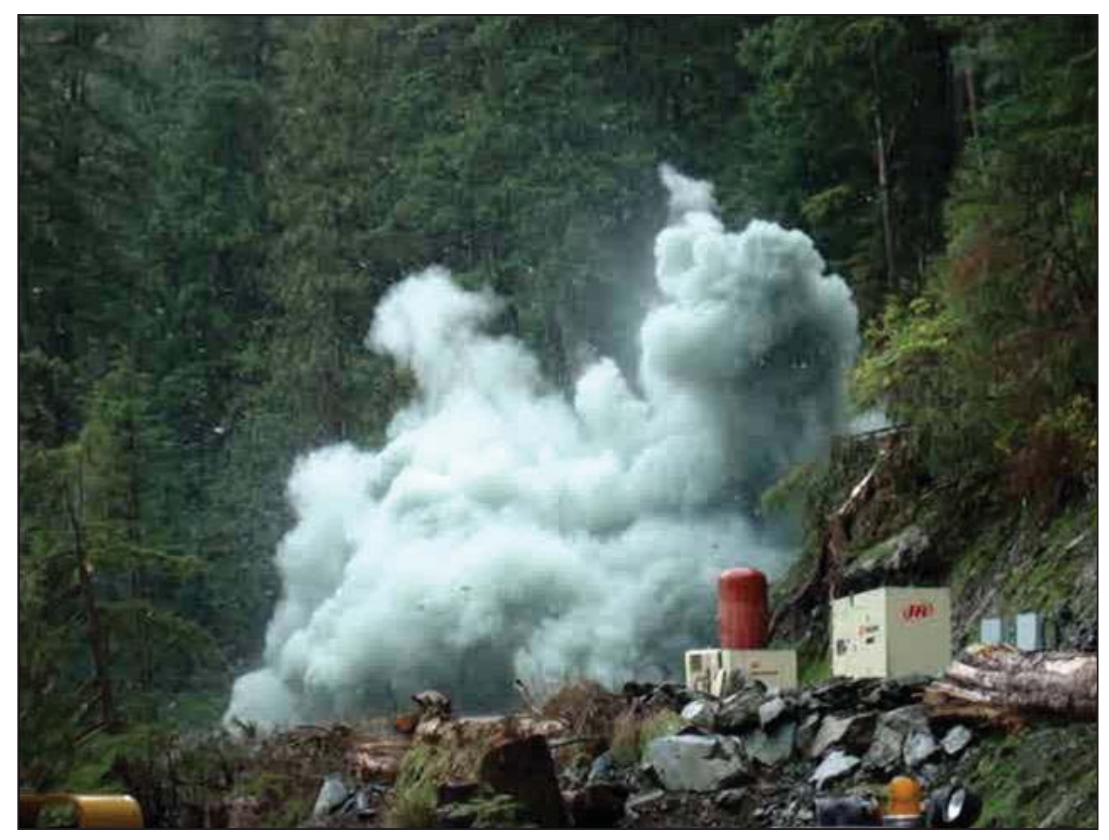

Figure 16. Road building and access construction for underground exploration at the Niblack VMS property. Photo provided by Niblack Mining Corp. 
Coeur Alaska Inc. completed 2,189 feet of exploration drilling from surface platforms on the Jualin property and 12,873 feet of underground drilling at Kensington for a total of 15,062 feet. No results were announced.

Ucore Uranium Inc. formed a joint venture with Landmark Minerals Inc. to acquire, through staking and option agreements with claim holders, a 100 percent interest in the Bokan Mountain uranium-rare-earth-element property. The property includes the Ross-Adams uranium deposit, with a total of 1.3 million pounds of uranium produced at an average grade of 0.76 percent $\mathrm{U}_{3} 0_{8}$ during three separate production periods between 1957 and 1971. Uranium and rare-earth-element mineralization, uraninite, uranothorite, and coffinite, is hosted within or near a circular Jurassic-age A-type peralkaline intrusive complex, including pipes, shear zone-related pods or lenses, and pegmatitic dikes. Alteration includes albite, chlorite, calcite, fluorite, and hematite. A helicopter-borne radiometric and magnetic survey was completed by Precision GeoSurveys Inc. with grid lines spaced at 320-foot intervals (fig. 17). Nine diamond drill holes, totaling 1,385 feet, were completed at the previously tested but unmined I\&L zone. All holes intersected uranium mineralization, with the best mineralization in hole LM07-01, intersecting 164.8 feet of mineralization averaging 0.47 percent $\mathrm{U}_{3} 0_{8}$ and hole LM07-05, intersecting 50 feet of 0.47 percent $\mathrm{U}_{3} 0_{8}$.

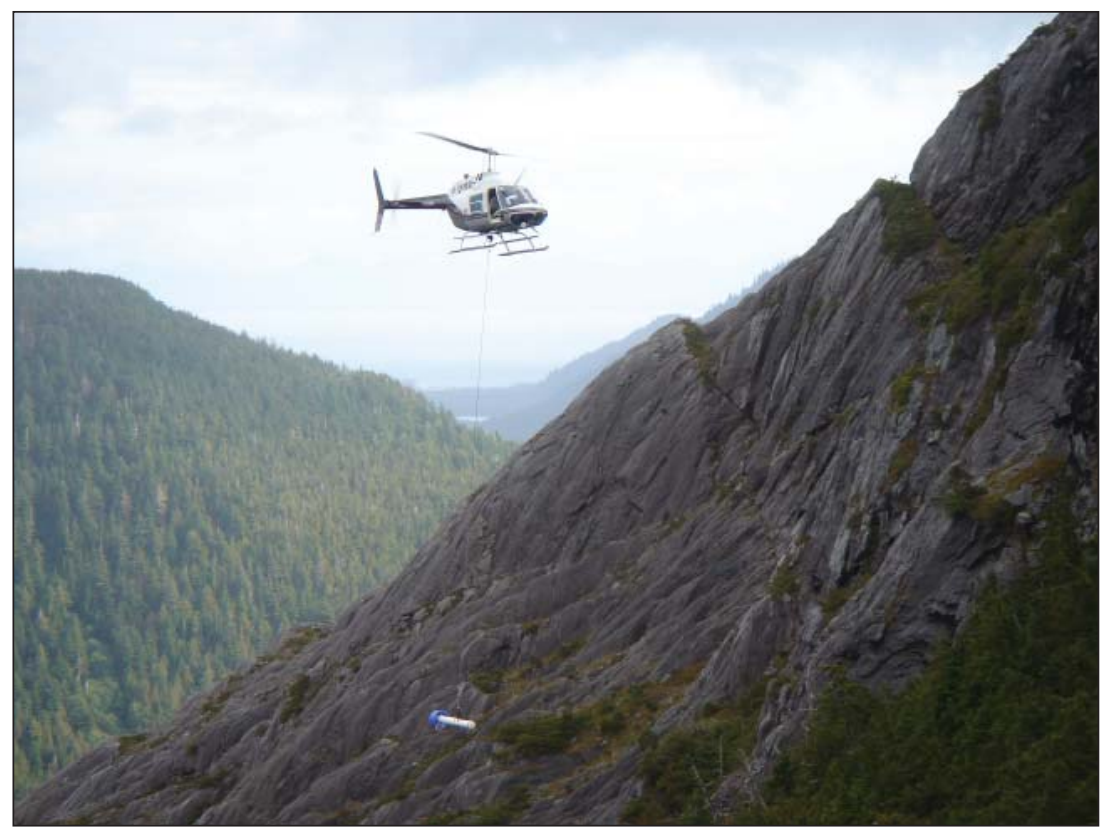

Figure 17. Precision GeoSurveys Inc. conducting a helicopter-borne radiometric and magnetic survey in rugged terrain at Ucore Uranium Inc. and Landmark Minerals Inc. 's Bokan Mountain uranium-rare-earth-element property. Photo provided by Ucore Uranium Inc.
Constantine Metal Resources Ltd. drilled a total of 7,593 feet in seven holes at the Palmer project. Five holes were drilled at the Glacier Creek prospect. Hole CMR0709 intersected 58.9 feet, starting at 502.1 feet depth, of zinc-copper-rich barite-hosted sulfide mineralization in the Southwall fold limb, possibly equivalent to the Main zone, that assayed 7.76 percent zinc, 1.03 percent copper, 0.62 percent lead, 0.027 ounces of gold per ton, and 1.97 ounces of silver per ton. Hole CMR07-09 intersected a second interval of zinc-chert-barite mineralization, possibly equivalent to the RW zone, starting at 787foot depth, with 11.2 feet grading 11.17 percent zinc, 0.18 percent copper, and 0.53 ounces of silver per ton. Hole CMR07-07 intersected 45.90 feet of 3.79 percent copper, 7.24 percent zinc, 0.011 ounces of gold per ton, and 1.372 ounces of silver per ton, thought to be the RW horizon. The last hole of the 2007 program (CMR0710) was drilled from the same location as CMR07-09 and intersected a major pyrite-pyrrhotite stringer and alteration zone over a core length of 1,013 feet from 468 -foot depth to the final hole depth of 1,481 feet. The Cap prospect target, about 1.67 miles west of the Glacier Creek prospect and on a separate mineral corridor, was tested by drill holes CMR07-04 and CMR07-05. Both holes intersected long intervals of altered pyritic rocks over intervals of 730 feet in CMR07-04 and 300 feet in CMR07-05. A 25.5-foot interval in hole CMR07-04 assayed 1.25 ounces of silver per ton, 1.2 percent zinc, and 0.60 percent lead. Constantine also staked 27 state claims in the area of the Palmer property in late September.

Bravo Venture Group Inc. reported that it completed detailed gravity and three-dimensional IP geophysical surveys and two core holes totaling 1,419 feet at the East Lake volcanogenic massive sulfide target on its Woewodski Island project. Both holes (WW07-034 and -035) contained greater than 50 -foot-thick downhole intervals of anomalous silver and zinc with associated anomalous, but less continuous, barium and gold values. Much of the 2007 exploration program focused on the Blue Quartz and Red Quartz gold prospects along the western and southern margins of Woewodski Island 
where 33 relatively short core holes were drilled for a total of 8,337 feet. Drilling targeted gold-quartz veins that occur within broad, up to 30-foot-thick, stronglycarbonate-altered shears. Quartz veins were intersected in many of these holes and higher-grade results include 13.7 feet grading 0.117 ounces of gold per ton, and 2.4 feet grading 0.210 ounces of gold per ton.

Full Metal Minerals mapped and collected rock and soil samples of a sediment-hosted, structurally controlled, high-grade gold vein system at the CJ property on east-central Prince of Wales Island. Historic and recent assay data indicate gold:silver ratios ranging from 1:1 to $1: 10$, with mineralization occurring as native gold and fine-grained sulfides. Altair Ventures Inc. optioned the property in a joint-venture agreement to earn a 60 percent interest in the property and supported an 8-hole, 3,330-foot drill program. All eight holes encountered gold mineralization, spanning more than 1 mile of strike length. Best drill results include hole CJ07-01, drilled to explore the down-dip extension of vein mineralization mined at the Crackerjack Mine, with a 10.5-foot intercept grading 0.144 ounces of gold per ton and 0.167 ounces of silver per ton, and hole CJ07-03, also drilled to explore the down-dip extension of vein mineralization mined at the Crackerjack Mine, with a 20.5-foot intercept grading 0.080 ounces of gold per ton and 1.245 ounces of silver per ton.

Full Metal Minerals completed a 13-hole, 4,892foot drilling program to test multiple copper-iron targets at the Mount Andrew property on the Kasaan Peninsula of Prince of Wales Island by stepping-out from historic workings and from 2006 drill sites. Copper mineralization occurs along an 8.7-mile-long trend within semi-massive to massive magnetite bodies within andesitic volcanic rocks and associated intermediate intrusive rocks, crosscut by later post-mineralization dikes. Andestic rocks commonly exhibit skarn-style alteration, coupled with strong sodic and potassic alteration. The mineralization is interpreted by Full Metal to represent an iron-oxide copper-gold (IOCG) system. Multiple zones of high-grade copper hosted within massive magnetite were encountered in drilling, including 72 feet averaging 1.24 percent copper and 30.3 percent iron in hole KMA07-06, 187 feet averaging 0.48 percent copper and 35.7 percent iron in hole KMA07-07, 37.5 feet averaging 1.24 percent copper and 37.1 percent iron in hole KMA07-10, and 45.9 feet averaging 1.46 percent copper, 32.8 percent iron, and 0.169 ounces of silver per ton in hole KMA07-11.

Quaterra Resources Inc. optioned 17 federal claims from JEDI Syndicate, longtime Juneau prospectors, at the Herbert Glacier gold property near Juneau, and staked an additional 67 federal claims around the property. Mineralization is hosted in at least four vein-fault structures in altered diorite that contain banded or ribbon quartz-sulfide (arsenopyrite, pyrite, and galena, with lesser chalcopyrite, sphalerite, and scheelite) veins. Quaterra collected 199 rock chip samples and did reconnaissance mapping of the property over the summer. Nearly half the samples collected assayed at more than 0.03 ounces of gold per ton and included one sample of a 1.5-foot-wide banded quartz vein with visible gold that assayed at 2.39 ounces of gold per ton.

Quaterra also contracted an expert in ultramafic-related ore deposits to review all data from its Duke Island project and make recommendations for further work, if any. The primary conclusion was that the ultramafic rocks may be related to a layered mafic intrusive complex with potential for hosting $\mathrm{Cu}-\mathrm{Ni}$-PGE mineralization in economic quantities. The study identified several undrilled targets with higher grade potential and recommended an airborne electromagnetic survey.

Other work in southeastern Alaska included Pure Nickel staking 115 federal mining claims and acquiring an additional 94 contiguous federal claims at the Salt Chuck property.

\section{DEVELOPMENT}

Reported and estimated mineral development expenditures in 2007 were approximately $\$ 318.8$ million, a 35.7 percent decrease from the 2006 value of $\$ 495.7$ million. The decrease is a result of the completion of the Pogo project and near completion of the Kensington project. Development continued at the Rock Creek project near Nome. Construction was completed at the Mystery Creek project at Nixon Fork and operation was commissioned in the first quarter. Significant expenditures were noted at Red Dog Mine, Fort Knox Mine, the Chuitna Coal project, Greens Creek Mine, and the Kensington project. Total full-time-equivalent employ- ment dedicated to development amounted to 735 for the year compared to 848 for 2006 .

Table 8 shows development investment and regional employment. Table 9 compares the 2007 investment with that of the previous 26 years by commodity. Figure 18 shows the locations of selected development projects. Development activity was reported in all but the Alaska Peninsula region.

\section{NORTHERN REGION}

Total expenditures in the region amounted to $\$ 41.4$ million, all at Red Dog Mine. 
Table 8. Reported mineral development expenditures and employment in Alaska by commodity and region, 2007

\begin{tabular}{|c|c|c|c|c|c|c|c|c|c|}
\hline & Northern & Western & $\begin{array}{l}\text { Eastern } \\
\text { Interior }\end{array}$ & $\begin{array}{l}\text { South- } \\
\text { central }\end{array}$ & $\begin{array}{c}\text { South- } \\
\text { western }\end{array}$ & & $\begin{array}{l}\text { laska } \\
\text { ninsula }\end{array}$ & $\begin{array}{l}\text { South- } \\
\text { eastern }\end{array}$ & Total \\
\hline \multicolumn{10}{|c|}{ Development Expenditures } \\
\hline Base metals & $\$ 41,374,880$ & -- & $\$$ & -- & - & $\$$ & - & -- & $\$ 41,374,880$ \\
\hline Polymetallic & -- & -- & - & -- & - & & -- & $30,766,902$ & $30,766,902$ \\
\hline \multicolumn{10}{|l|}{ Precious metals } \\
\hline Placer & -- & 182,750 & 95,300 & 26,500 & 850,000 & & -- & -- & $1,154,550$ \\
\hline Lode & -- & $96,832,023$ & $49,474,467$ & -- & 20,000 & & -- & $92,300,000$ & $238,626,490$ \\
\hline Coal and peat & -- & - & 385,000 & $5,000,000$ & - & & - & -- & $5,385,000$ \\
\hline Industrial minerals & -- & -- & 270,500 & $1,050,000$ & -- & & -- & -- & $1,320,500$ \\
\hline Other & -- & -- & -- & 150,000 & - & & -- & -- & 150,000 \\
\hline TOTAL & $\$ 41,374,880$ & $\$ 97,014,773$ & $\$ 50,225,267$ & $\$ 6,226,500$ & $\$ 870,000$ & $\$$ & - & $\$ 123,066,902$ & $\$ 318,778,321$ \\
\hline \multicolumn{10}{|c|}{ Development Employment } \\
\hline \multicolumn{10}{|l|}{ Employment } \\
\hline Workdays & 15,699 & 60,491 & 16,481 & 10,434 & 320 & & 0 & 87,552 & 190,977 \\
\hline Workyears $^{\mathrm{a}}$ & 60 & 233 & 63 & 40 & 1 & & 0 & 337 & 735 \\
\hline \multicolumn{10}{|l|}{ No. of companies } \\
\hline reporting ${ }^{\mathrm{b}}$ & 4 & 6 & 12 & 7 & 3 & & 0 & 2 & 34 \\
\hline
\end{tabular}

Table 9. Reported mineral development expenditures in Alaska by commodity, 1982-2007

\begin{tabular}{|c|c|c|c|c|c|c|}
\hline & $\begin{array}{c}\text { Base } \\
\text { metals }\end{array}$ & Polymetallics & $\begin{array}{c}\text { Precious } \\
\text { metals }\end{array}$ & $\begin{array}{c}\text { Industrial } \\
\text { minerals }\end{array}$ & $\begin{array}{c}\text { Coal and } \\
\text { peat }\end{array}$ & Total \\
\hline 1982 & $\$ 10,270,000$ & N/A & $\$ 19,320,000$ & $\$ 4,251,000$ & $\$ 7,750,000$ & $41,591,000$ \\
\hline 1983 & $19,500,000$ & N/A & $7,112,500$ & $1,000,000$ & 250,000 & $27,862,500$ \\
\hline 1984 & $10,710,500$ & N/A & $15,058,555$ & 579,000 & $27,000,000$ & $53,348,055$ \\
\hline 1985 & $13,000,000$ & N/A & $16,890,755$ & $1,830,000$ & $2,400,000$ & $34,120,755$ \\
\hline 1986 & $3,260,800$ & $8,000,000$ & $12,417,172$ & 124,000 & 530,000 & $24,331,972$ \\
\hline 1987 & $38,080,000$ & $48,000,000$ & $13,640,848$ & 188,000 & 342,000 & $100,250,848$ \\
\hline 1988 & $165,500,000$ & $69,000,000$ & $40,445,400$ & -- & - & $274,945,400$ \\
\hline 1989 & $118,200,000$ & 411,000 & $6,465,350$ & $7,000,000$ & $2,196,000$ & $134,272,350$ \\
\hline 1990 & -- & $4,101,000$ & $7,136,500$ & 30,000 & $3,079,000$ & $14,346,500$ \\
\hline 1991 & - & $8,000,000$ & $14,994,350$ & 262,000 & $2,318,000$ & $25,574,350$ \\
\hline 1992 & 80,000 & $4,300,000$ & $23,151,300$ & 404,000 & $1,655,000$ & $29,590,300$ \\
\hline 1993 & -- & $10,731,136$ & $15,103,000$ & 433,500 & $1,400,000$ & $27,667,636$ \\
\hline 1994 & $10,000,000$ & $5,000,000$ & $27,392,850$ & 5,000 & $2,545,000$ & $44,942,850$ \\
\hline 1995 & $11,200,000$ & $9,590,000$ & $127,165,750$ & 426,000 & 200,000 & $148,581,750$ \\
\hline 1996 & $60,000,000$ & $60,100,000$ & $273,042,000$ & 495,000 & 400,000 & $394,037,000$ \\
\hline 1997 & $133,880,000$ & $7,300,000$ & $26,299,000$ & 500,000 & 410,000 & $168,389,000$ \\
\hline 1998 & $28,000,000$ & $5,600,000$ & $15,602,000$ & $5,355,000$ & 850,000 & $55,407,000$ \\
\hline 1999 & $12,500,000$ & $2,500,000$ & $15,864,000$ & 400,000 & $2,575,000$ & $33,839,000$ \\
\hline 2000 & $100,000,000$ & $16,400,000$ & $24,699,000$ & 611,000 & - & $141,710,000$ \\
\hline 2001 & $43,800,000$ & $3,300,000$ & $32,719,000$ & 300,000 & $1,040,000$ & $81,159,000$ \\
\hline 2002 & -- & $5,700,000$ & $26,655,000$ & 250,000 & $1,450,000$ & $34,055,000$ \\
\hline 2003 & - & - & $38,839,332$ & 315,000 & - & $39,154,332$ \\
\hline 2004 & $17,700,000$ & $6,215,000$ & $177,440,081$ & $4,991,434$ & $2,760,000$ & $209,106,515$ \\
\hline 2005 & $28,000,000$ & $16,700,000$ & $301,011,469$ & 856,500 & $1,350,000$ & $347,917,969$ \\
\hline 2006 & $31,200,000$ & $26,183,280$ & $420,759,203$ & $1,566,000$ & $15,985,000$ & $495,693,483$ \\
\hline $2007^{a}$ & $41,374,880$ & $30,766,902$ & $239,931,040$ & $1,320,500$ & $5,385,000$ & $318,778,322$ \\
\hline TOTAL & $\$ 896,256,180$ & $\$ 347,898,318$ & $\$ 1,939,155,455$ & $\$ 33,492,934$ & $\$ 83,870,000$ & $\$ 3,300,672,887$ \\
\hline
\end{tabular}


I Northern Region

1. Red Dog Mine

2. Nolan Creek Mine - Silverado Gold Mines Ltd.

\section{Western Region}

3. Nome Placers

4. Rock Creek Project - NovaGold Resources, Inc. (mill and mine construction)

5. Nixon Fork Mine - Mystery Creek Resources, St. Andrew Goldfields (completion of construction)

III Eastern Interior Region

6. Fairbanks area

a. Fort Knox Mine - Kinross Gold Corp. (stripping, heap leach pad construction, SAG mill reject)

b. Several open-pit placer mines

c. Several rock, sand, and gravel operations (equipment)

7. Pogo Project - Teck Cominco Alaska Inc./ Sumitomo Metals Mining America Inc. (underground development)

8. Usibelli Coal Mine - (road building, drilling)

9. Cleary Summit - Freegold Ventures Ltd. (plant construction, test mining)

\section{Southcentral Reegion}

10. Chuitna Coal Project - PacRim Coal LP (studies, permitting)

11. Gemstone development - Diamond-Gold Corp. (stripping, trenching, plant construction)

12. Gravel - Wilder Construction (materials handling)

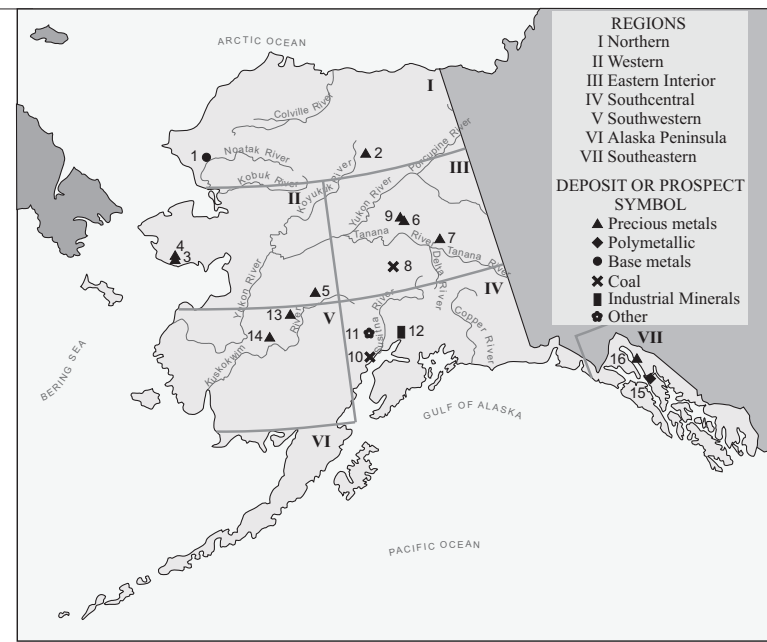

V Southwestern Region

13. Innoko Placer - Innoko Resources Group - placer development

14. Placer development - Lyman Resources (stripping)

\section{Alaska Peninsula Region}

VII Southeastern Region

15. Greens Creek Mine - Kennecott Minerals Co./ Hecla Mining Co. (underground development)

16. Kensington Project - Coeur Alaska Inc. (permitting, mill, and underground construction)

Figure 18. Selected development projects, 2007.

Capital expenditures at Red Dog Mine, owned and operated by Teck Cominco, were $\$ 41.4$ million during the year. Projects included $\$ 8.4$ million for additional flotation capacity, $\$ 18.6$ million for tailings dams upgrading, \$13.0 million on other sustaining capital projects, and $\$ 1.3$ million on in-fill drilling at the Aqqaluk deposit. The Aqqaluk in-fill drilling amounted to 28,097 feet of core hole drilling. Employment allocated to development activity was 65 full-time-equivalent positions during the year.

Efforts to define a useable gas source at Red Dog to replace diesel power generation continued during the year. After completing three holes in a five-spot pattern in the summer of 2007, the program has switched to monitoring the rate of gas production. The monitoring process started by dewatering the drill holes, which was initiated in the spring of 2007. Pumping will continue for a couple years to allow gas to flow to the hole and for accurate monitoring of its rate of generation. Once monitoring information is in hand, the next steps will be determined.

\section{WESTERN REGION}

Development expenditures were reported for lode, placer, and sand and gravel projects. Six projects reported development expenditures amounting to $\$ 97.0$ million compared to $\$ 55.7$ million for 2006 , an increase of 74.1 percent. Total employment associated with these expenditures was 233 full-time-equivalent positions.

NovaGold Resources Inc. began construction on the Rock Creek and Big Hurrah projects in late August 2006 (fig. 19). Construction continued through 2007 but permit challenges, resource constraints, unforeseen issues with equipment, severe weather conditions, and other factors delayed its completion. The U.S. Army Corps of Engineers (COE) suspended the 404 permit for the Rock Creek project on December 6, 2006, to review the permit evaluation and decision documents. A complaint had been filed against the COE by a Nome group arguing that there had not been a sufficient public process. A modified COE permit was restored on March 13,2007 , that contained additional stipulations that covered reporting and mitigation. Expenditures for mining and milling equipment and construction of facilities during 2007 were reported to be $\$ 78.0$ million. Forecast 


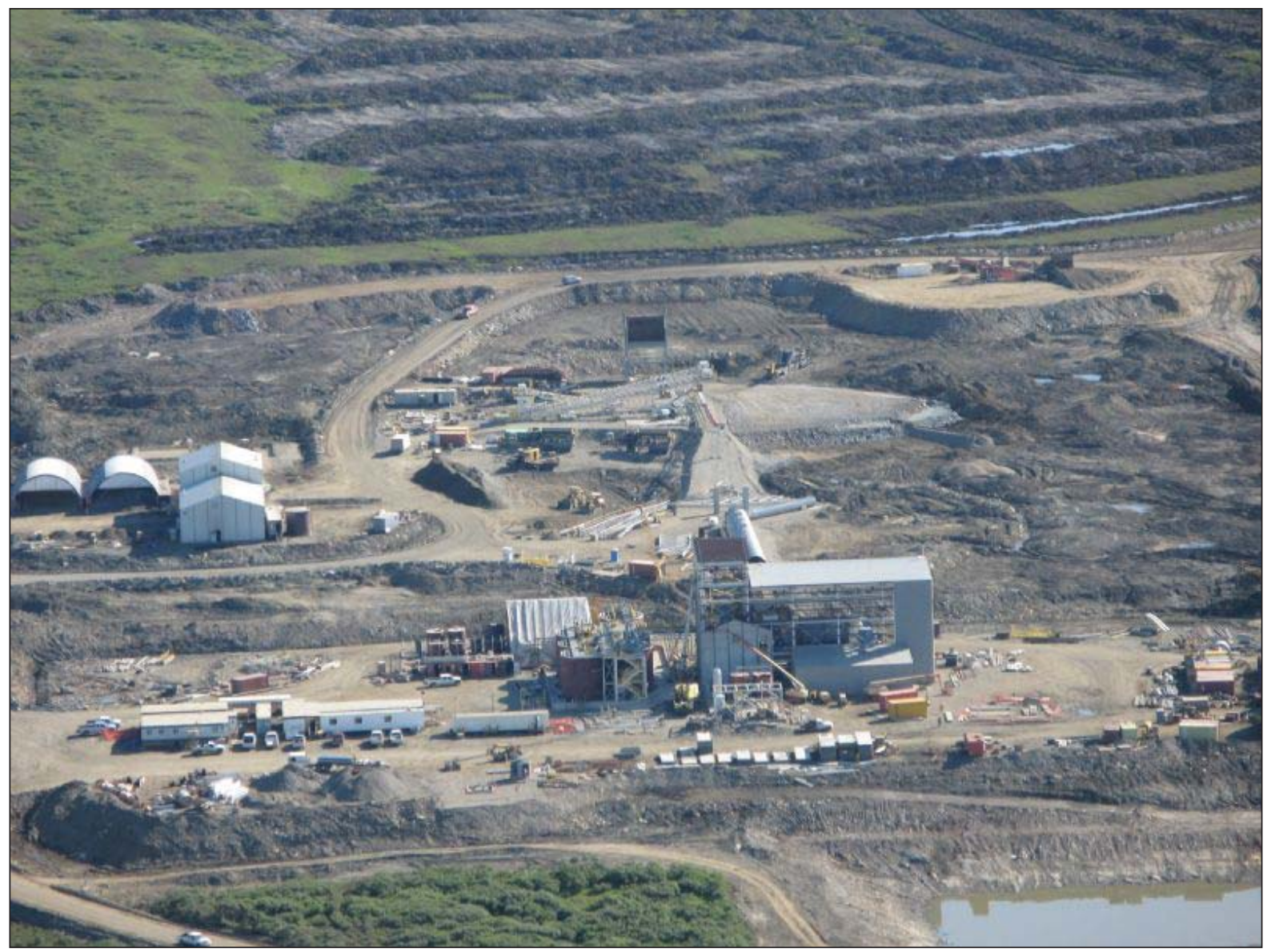

Figure 19. Aerial view of construction at NovaGold Resources Inc.'s Rock Creek gold mine and mill complex. Photo provided by NovaGold Resources Inc.

expenditures for 2008 are $\$ 30$ million. The capital cost estimate in the feasibility study was $\$ 158$ million, but, given the current status of construction, the total outlay is expected to exceed this amount. Employment averaged 114 full-time-equivalent positions during the year. Probable reserves at Rock Creek and Big Hurrah are 8.6 million tons at a grade of 0.0379 ounces of gold per ton and 1.32 million tons at 0.140 ounces of gold per ton, respectively (table 10). The company expects to commission the operation during 2008 and bring in $\$ 28$ million in free cash flow. The planned production rate is 7,700 tons per day to produce 100,000 ounces per year during full capacity. Employment is forecast at 160 persons.

Mystery Creek Resources Inc., a wholly owned subsidiary of St. Andrew Goldfields Ltd., completed construction at the Nixon Fork project during the first part of the year. The company encountered ore production issues in the upper portion of the 3300 zone of the Crystal deposit. The actual geometry of the mineralized zone was found to be much different than that used in the mineral reserve estimate. On August 14, the company announced that milling operations would be shut down for about 6 weeks to perform modifications to the mill circuits. On October 10, ongoing construction of these projects, mainly the cyanide leach facility and the installation of dry stack tailings disposal system, was also suspended. Construction and other capitalized costs amounted to $\$ 7.7$ million for the year. Activity since the suspension has been directed at re-definition of ore reserves and resources and wrapping up construction projects. The property has been put up for sale. Employment allocated to construction and other development activity amounted to 15 full-time-equivalent positions for the year.

\section{EASTERN INTERIOR REGION}

Total construction expenditures allocated to the Eastern Interior region amounted to $\$ 50.2$ million compared to $\$ 249.9$ million for 2006 . This reduction of $\$ 199.7$ million, or 79.9 percent, was primarily attributable to the completion of construction and capitalization at the Pogo project. A total of 12 projects reported development activity. Employment allocated to development amounted to 63 full-time-equivalent persons for the year. 
Table 10. Gold reserves and resources at Rock Creek, Big Hurrah, and various holdings at Nome, as of December 31, 2007

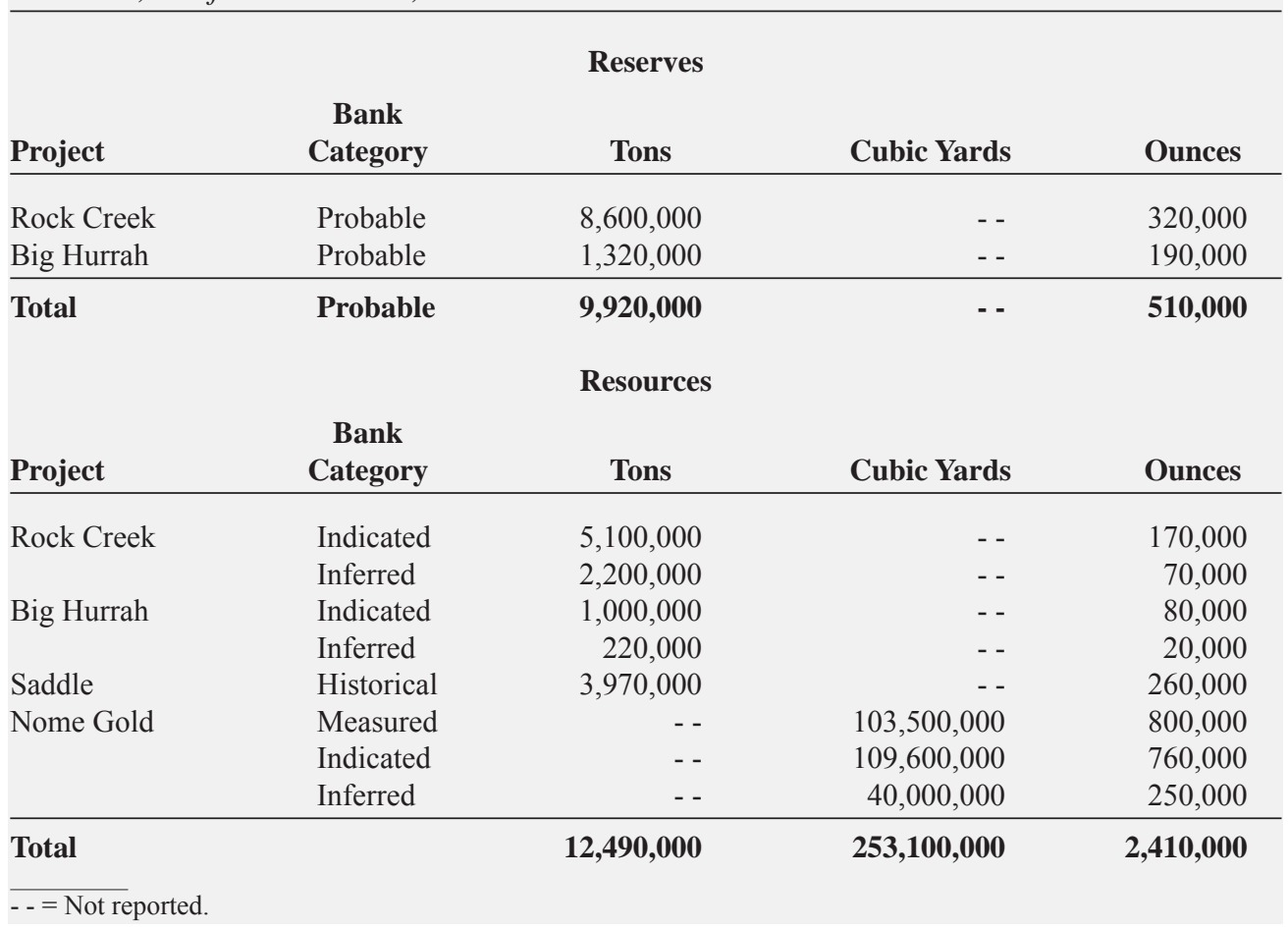

The Pogo gold mine, operated by Teck Pogo Inc., is a joint venture between Sumitomo Metal Mining Co. Ltd. (51 percent), Sumitomo Corp. (9 percent), and Teck Cominco Ltd. (40 percent). Pogo was declared to have reached commercial production in April 2007. However, the underground mine has not reached full capacity of 2,500 tons per day; the surface ore stockpile accumulated during the fourth quarter 2006 power failure was essentially depleted. Capital expenditures at the project during 2007 were \$17.7 million and included an upgrade of living quarters to accommodate added underground development contractor personnel and capitalization of operating losses (\$2 million) ${ }^{4}$ for the first part of 2007. A third filter press was commissioned and modifications to the filtered tailings handling system to improve paste backfilling were completed in the first quarter of 2007. At year end Pogo had 251 employees and 88 additional persons employed by contractors in housekeeping and underground development.

Development expenditures at Fort Knox Mine amounted to $\$ 30$ million during 2007. The mine is operated by Fairbanks Gold Mining Co. Inc., a wholly owned subsidiary of Kinross Gold Corp. Efforts included stripping in phase 6 , construction of the Walter Creek Heap

$\overline{{ }^{4} \text { Teck Cominco } 2007 \text { annual report. }}$
Leach facility, and construction of a SAG mill reject conveyor. Manpower allocation to the development effort was 43 full-time-equivalent persons for the year.

Stripping of phase 7 is scheduled to begin in the fourth quarter of 2008. Phase 7 (southwest side) contains 33.1 million tons of ore, mining of which was dependent on permitting of the Walter Creek Heap Leach facility. The Walter Creek Heap Leach Certificate of Approval to Construct a Dam was received from the Corps of Engineers on October 31, 2007. The proposed Walter Creek fill heap leach facility project will be situated in the northwest portion of the mine site, upstream of the Fort Knox tailings impoundment and seepage collection system. The heap leach project would encompass 403 acres, including 57.6 acres of federal waters, and the facility would be capable of handling 161 million tons of rock. The Alaska Departments of Natural Resources and Environmental Conservation issued state authorizations for the project on July 3. Phase 7 stripping will allow Fort Knox pit production to continue until 2014. Stockpile material will be mined and placed on the heap leach facility until 2017.

Water with trace amounts of cyanide was found seeping from a hillside near the Fort Knox Mine tailings dam during the year. Fairbanks Gold Mining Inc. spent in excess of $\$ 2.5$ million to deal with the water seep, including digging a trench to collect the seep and 
installing some additional interceptor wells on the valley floor below the tailings dam.

Other development activities were noted for an additional ten projects in the Interior. Development expenditures for these projects amounted to $\$ 2.5$ million. The most significant portion of this was spent by Freegold Ventures Ltd. at the Golden Summit project north of Fairbanks in test mining of the property. Other notable projects included placer, coal, and sand and gravel projects.

\section{SOUTHCENTRAL REGION}

Development expenditures totaling $\$ 6.2$ million were reported for seven projects in 2007 , in contrast to $\$ 8.98$ million spent in 2006, a 31 percent reduction. Commodities to which these expenditures and efforts were applied included placer, coal, peat, sand and gravel, and gemstones. Employment corresponding to this region's development was 40 full-time-equivalent employees.

PacRim Coal LP continued environmental, permitting, and engineering work on the Chuitna Coal project, located west of Anchorage on the north side of Cook Inlet. The project is being designed to include a coal export terminal at Ladd Landing, connected to the mine with a 12-mile-long covered conveyor. Mine production capacity is designed to handle 3 to 12 million tons per year. Proven reserves are reported to be 772 million tons. Twenty employees were credited to the project for 2007.

Diamond-Gold Corp. undertook development activity at its Sable Elegance (diamond and colored gemstones) property in the Yentna mining district in the Alaska Range during the year. Activities included trenching and wash plant construction.

Five additional projects reported development activity during 2007; three projects were developed for sand and gravel production and two for placer gold recovery.

\section{SOUTHWESTERN REGION}

Limited development activity was reported for this region during 2007. Total expenditures were $\$ 870,000$ from three placer gold projects. One man-year of activity was credited to this effort.

\section{ALASKA PENINSULA REGION}

No development expenditures were reported in this region for 2007.

\section{SOUTHEASTERN REGION}

The southeastern region experienced the most development expenditures of any region during 2007. Development construction continued at Kensington project and ongoing development was undertaken at Greens
Creek Mine. Expenditures totaled \$123.1 million and employment was approximately 337 employees.

Construction at Coeur Alaska Inc.'s Kensington underground gold mine complex in southeastern Alaska, 45 miles north of Juneau, continued through 2007, although work on the tailings facility remained suspended. Efforts included construction of the mill and supporting surface facilities and underground development (fig. 20). Expenditures during the year were $\$ 92.3$ million in connection with development of the mine, nearly 20 percent higher than an estimate of $\$ 77.7$ million. Total development expenditures to the end of 2007 amounted to $\$ 269.7$ million. Coeur Alaska plans to spend \$26.2 million on the project during 2008. Employment, including contractors, during 2007 is estimated to be 292 full-time-equivalent persons. The company believes that production could begin in 2009, subject to successful and timely resolution of the legal issues more fully described below or if the permit were modified to allow for an alternate tailings facility. Coeur is proceeding with permitting for a paste tailings storage facility on the Lynn Canal side of the project should litigation fail to resolve the disposal in Lower Slate Lake.

Reserves at Kensington amount to 4,418,600 tons with a grade of 0.306 ounces per ton gold, containing $1,352,100$ ounces. An additional resource of 4,320,000 tons containing 866,000 ounces of gold exists at the project. Coeur plans a production rate of 100,000 ounces per year at a cash cost of $\$ 310$ per ounce. The milling process will involve treating approximately 1,100 tons of ore per day and will involve primary crushing, SAG mill grinding, gravity, and flotation concentration, with about 40 percent of the tailings returned to the mine for backfill; the remaining tailings will be sent to the selected tailings disposal facility to be part of the court resolution. Concentrates will be packaged and shipped off site for final gold recovery. The mine will provide about 225 direct and approximately 500 indirect jobs.

Kensington construction was started in mid-2005 upon receipt of all permits, but on September 12, 2005, non-governmental organizations (NGO) lawsuits were filed against the Army Corps of Engineers (COE) and the U.S. Forest Service (USFS), resulting in suspension on November 22 of construction of tailings disposal facilities in Lower Slate Lake. On March 29, 2006, the COE reinstated Coeur Alaska's Section 404 permit; however, on April 6, the lawsuit challenging the permit was re-opened. On August 4, the Federal District Court in Alaska dismissed the Plaintiffs' challenge and upheld the Section 404 permit. On August 7, the Plaintiffs filed a Notice of Appeal of the decision to the Ninth Circuit Court of Appeals, and on August 9, Plaintiffs additionally filed a Motion for Injunction Pending Appeal with the Circuit Court. On August 24, 2006, the Circuit Court 


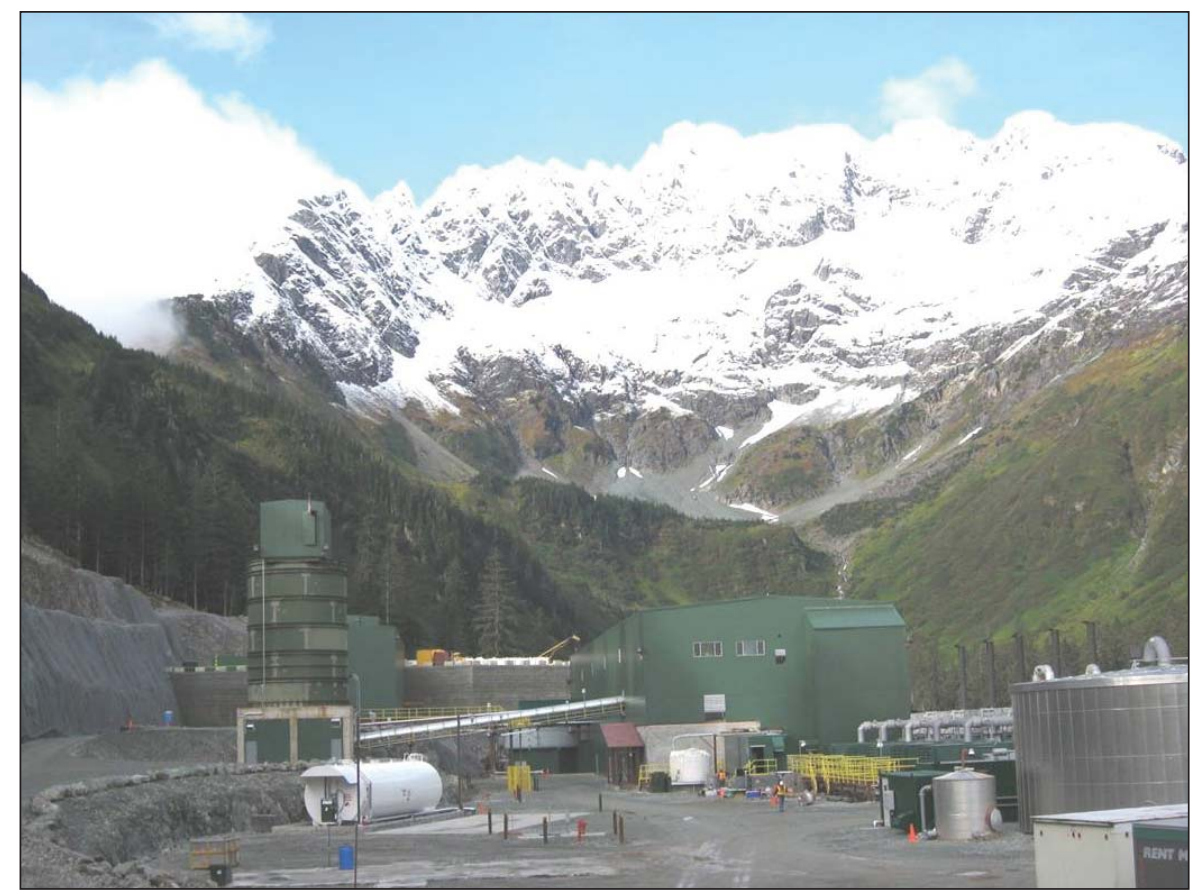

Figure 20. Coeur Alaska Inc. 's mill complex at the Kensington gold property, with Lions Head Mountain in the background. Photo provided by Coeur Alaska Inc.

granted a temporary injunction pending appeal, enjoining certain activities relating to the lake tailings facility. The Circuit Court further ordered an expedited briefing schedule on the merits of the legal challenge.

The parties filed their briefs by October 13, 2006, and participated in an oral argument on December 4. On May 22, 2007, the Ninth Circuit Court reversed the District Court's August 4, 2006, decision that had upheld the company's 404 permit and issued its opinion that remanded the case to the District Court with instructions to vacate Coeur's 404 permit as well as the USFS Record of Decision approving the general tailings disposal plan as well as the Goldbelt 404 permit to construct the Cascade Point Marine Facility. On August 20, 2007, Coeur Alaska filed a Petition for Rehearing En Banc with the Ninth Circuit Court, as did the State of Alaska and Goldbelt Inc. In addition, the Department of Justice, on behalf of the Corps of Engineers and USFS, filed a limited Petition for Rehearing with the Ninth Circuit panel seeking reconsideration of the mandate of the May 22, 2007 panel decision. On October 29, the Ninth Circuit denied the Petitions for Rehearing En Banc. On November 14, the Ninth Circuit granted a stay of the mandate pending further appeal to the Supreme Court, subject to the development of a reclamation plan for the lake area. Coeur Alaska and the State of Alaska filed Petitions for Certiorari to the Supreme Court of the United States on January 28, 2008.
Capital expenditures at Greens Creek, owned by Kennecott Greens Creek (operator) and Hecla Mining Co., amounted to $\$ 30,766,902$ for 2007. Most of this expenditure was for development of ore. Manpower allocated to development amounted to 44.8 full-timeequivalent persons for the year.

Greens Creek Mine has historically been powered completely by diesel generators located on site. An agreement was reached during 2005 to purchase excess hydroelectric power from the local power company. Installation of the necessary infrastructure was completed in 2006, and use of hydroelectric power commenced during the third quarter of 2006. Low lake levels and increased demand in the Juneau area have combined to decrease power available to Greens Creek, and it is unlikely that Greens Creek will obtain sufficient utility power until 2009.5

Hecla Mining Co. announced the acquisition of the balance of the Greens Creek Mine on February 12, 2008. The transaction, amounting to $\$ 750$ million, transferred Kennecott's (Rio Tinto) 70.27 percent interest in the project to Hecla; the transaction was completed on April 16, 2008.

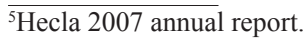




\section{PRODUCTION}

Mineral production value in Alaska during 2007 is estimated to be $\$ 3,367.0$ million. The estimate represents an increase in value of approximately $\$ 508.8$ million over the 2006 production values; this is a 17.8 percent change from 2006. Reporting shortfalls are noted in the placer and industrial minerals sectors, although there appears to be a fairly significant downturn in sand, gravel, and rock production. Metals (gold, silver, copper, lead, and zinc) account for $\$ 3,219.8$ million, coal and peat for $\$ 45.6$ million, and industrial minerals for $\$ 101.6$ million. Employment attributed to production is estimated to be 2,324 full-time positions.

The increased value of production can be attributed both to increased commodity production and to improved commodity prices; minor copper production was credited to the state for the first time in a number of years. Significantly higher gold production was noted due to commissioning of the Pogo Mine. All commodities with the exception of coal and rock were produced in larger quantities. Metal prices were higher in 2007 than in 2006 with the exception of zinc, which was the same.

Table 11 shows the estimated mineral production quantity and value for 2005 through 2007. Figures 21, 22 , and 23 show the historic production of sand and gravel, gold, and coal. Selected production sites are shown in figure 24.

Allocation of value of production by commodity is shown in figure 25 . Zinc leads with by far the most value at 60.84 percent, with Red Dog being the most significant contributor. Gold has moved forward to second place at 15.18 percent of total value. In descending order, the value of the remaining products are, lead at 11.57 percent, silver at 8.03 percent, industrial minerals at 3.02 percent, coal and peat at 1.36 percent, and copper at 0.01 percent.

Alaska mineral production value by sector/mine is shown in figure 26. Values of production, in decreasing order, were from Red Dog (70.08 percent), Greens Creek

Table 11. Estimated mineral production in Alaska, 2005-2007

\begin{tabular}{|c|c|c|c|c|c|c|}
\hline \multirow[b]{2}{*}{ Metals } & \multicolumn{3}{|c|}{ Production Quantities } & \multicolumn{3}{|c|}{ Estimated Values $^{\mathrm{b}}$} \\
\hline & 2005 & 2006 & 2007 & 2005 & 2006 & 2007 \\
\hline Gold (ounces) ${ }^{c}$ & 427,031 & 570,129 & 726,933 & $\$ 189,918,000$ & $\$ 344,049,779$ & $\$ 511,089,447$ \\
\hline Silver (ounces) & $11,670,000$ & $16,489,394$ & $20,203,985$ & $85,382,000$ & $190,415,907$ & $270,402,055$ \\
\hline Copper (tons) ${ }^{\mathrm{d}}$ & $-\mathrm{d}^{\mathrm{d}}$ & $-{ }^{d}$ & $43.8^{\mathrm{d}}$ & - - & - & 283,542 \\
\hline Lead (tons) & 131,366 & 157,128 & 167,181 & $115,230,000$ & $183,629,254$ & $389,532,215$ \\
\hline Zinc (tons) & 684,462 & 673,967 & 696,115 & $862,108,000$ & $2,002,971,414$ & $2,048,451,644$ \\
\hline Subtotal & & & & $\$ 1,252,638,000$ & $\$ 2,721,066,354$ & $\$ 3,219,758,903$ \\
\hline \multicolumn{7}{|l|}{ Industrial Minerals } \\
\hline (tons) & 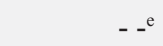 & -- & -- & - & -- & -- \\
\hline \multicolumn{7}{|l|}{ Sand and gravel } \\
\hline Rock (million tons) & 2.8 & 2.4 & 2.2 & $22,547,000$ & $23,846,024$ & $25,509,775$ \\
\hline Subtotal & & & & $\$ 99,084,000$ & $\$ 87,197,113$ & $\$ 101,629,165$ \\
\hline Coal (tons) & $1,402,174$ & $1,397,500^{\mathrm{f}}$ & $1,273,004$ & $49,076,000$ & $48,912,500$ & $44,555,140$ \\
\hline Peat (cubic yards) & 62,532 & 66,500 & 68,367 & 810,000 & $1,057,500$ & $1,085,500$ \\
\hline Subtotal & & & & $\$ 49,886,000$ & $\$ 49,970,000$ & $\$ 45,640,640$ \\
\hline \multicolumn{4}{|l|}{ TOTAL } & $\$ 1,401,608,000$ & $\$ 2,858,233,467$ & $\$ 3,367,028,708$ \\
\hline \multicolumn{7}{|c|}{$\begin{array}{l}\text { aproduction data from DGGS questionnaire, phone interviews with mine and quarry operators, ADOT\&PF, and municipalities, regional cor- } \\
\text { porations, and federal land management agencies. }\end{array}$} \\
\hline \multirow{2}{*}{\multicolumn{7}{|c|}{$\begin{array}{l}\text { 'Values for selected metal production were based on average prices for each year (unless other values were provided by the operator); for } \\
2007 \text {-gold } \$ 695.39 / \text { ounce, silver } \$ 13.38 / \text { ounce, copper } \$ 3.24 / 1 \mathrm{~b} \text {, lead } \$ 1.17 / \mathrm{b} \text {, zinc } \$ 1.47 / \mathrm{lb} \text {. }\end{array}$}} \\
\hline & & & & & & \\
\hline \multicolumn{7}{|c|}{$\begin{array}{l}\text { dGreens Creek Mine has historically been credited with a small copper concentrate production; no credit was experienced for } 2005-2007 \\
\text { production, but Nixon Fork Mine reported copper production. }\end{array}$} \\
\hline $\begin{array}{l}\text { eJade and soapstone credit } \mathrm{h} \\
\text { f } 2006 \text { production corrected }\end{array}$ & $\begin{array}{l}\text { as been droppe } \\
\text { rom } 9.3 \mathrm{M} \text { ton }\end{array}$ & & & & & \\
\hline
\end{tabular}




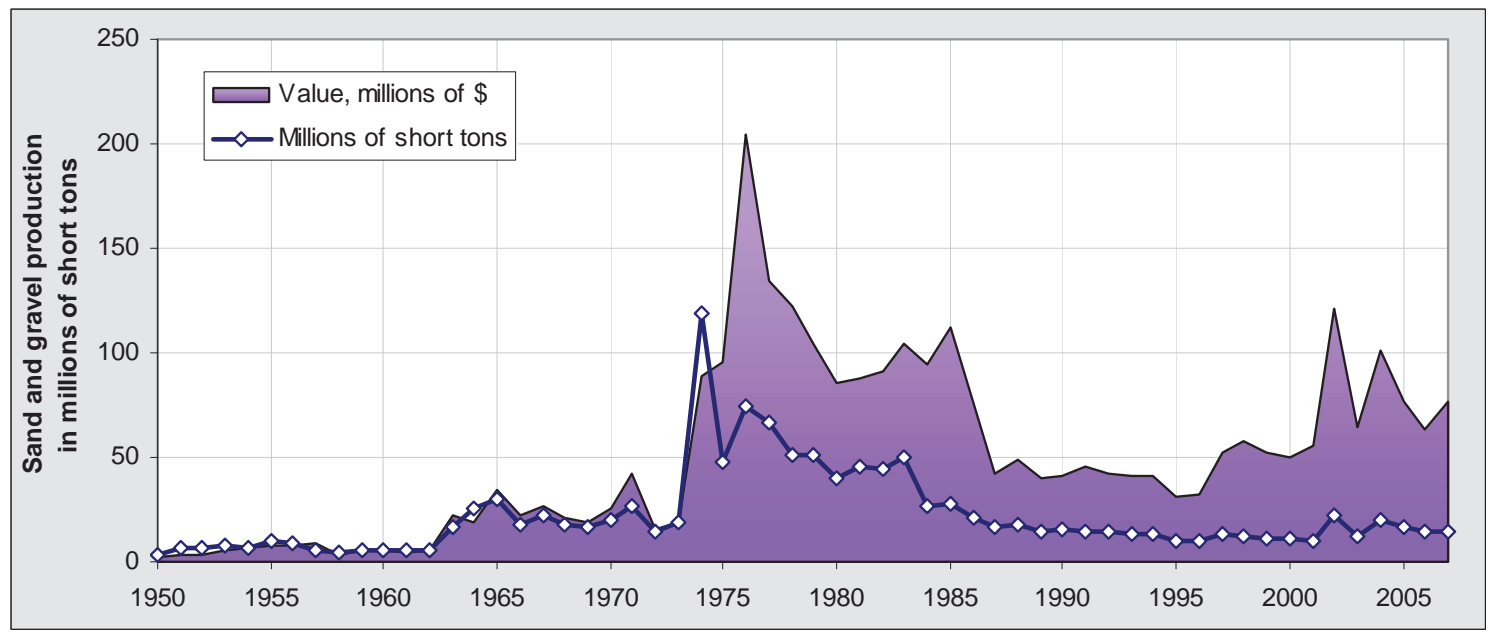

Figure 21. Sand and gravel production in Alaska 1950-2007.

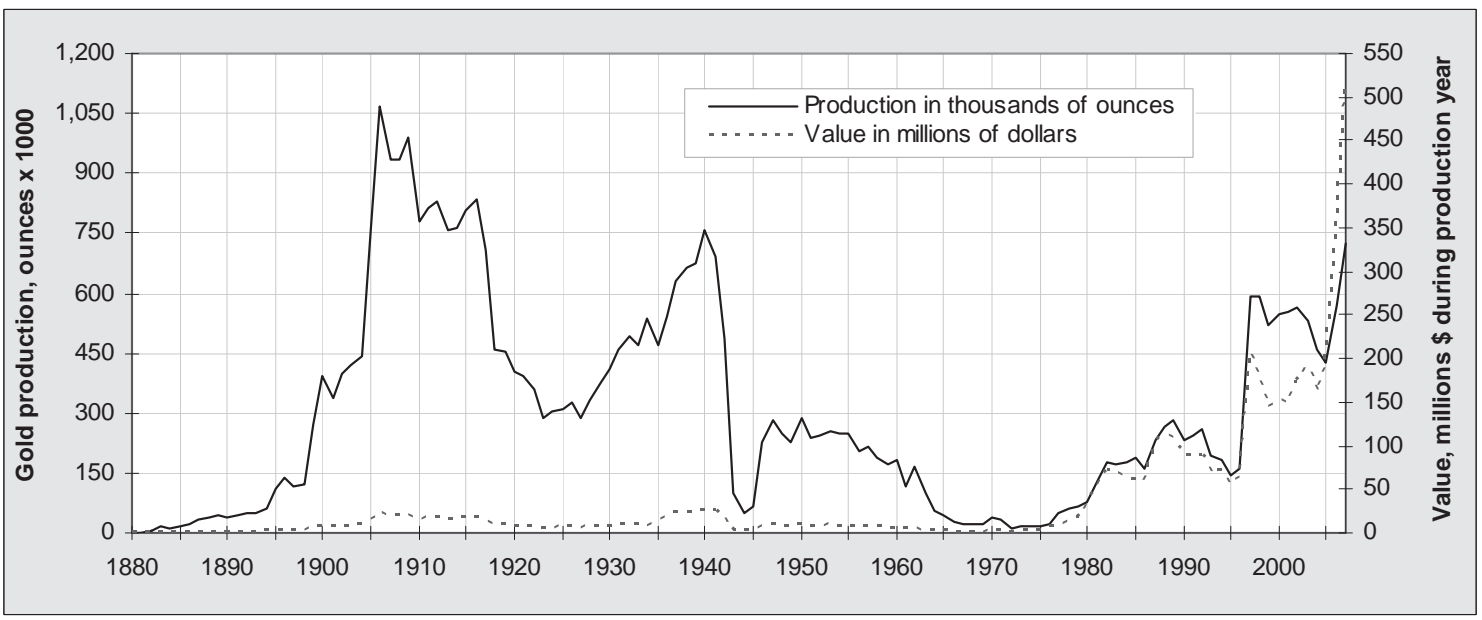

Figure 22. Amount of value of gold production in Alaska, 1880-2007.

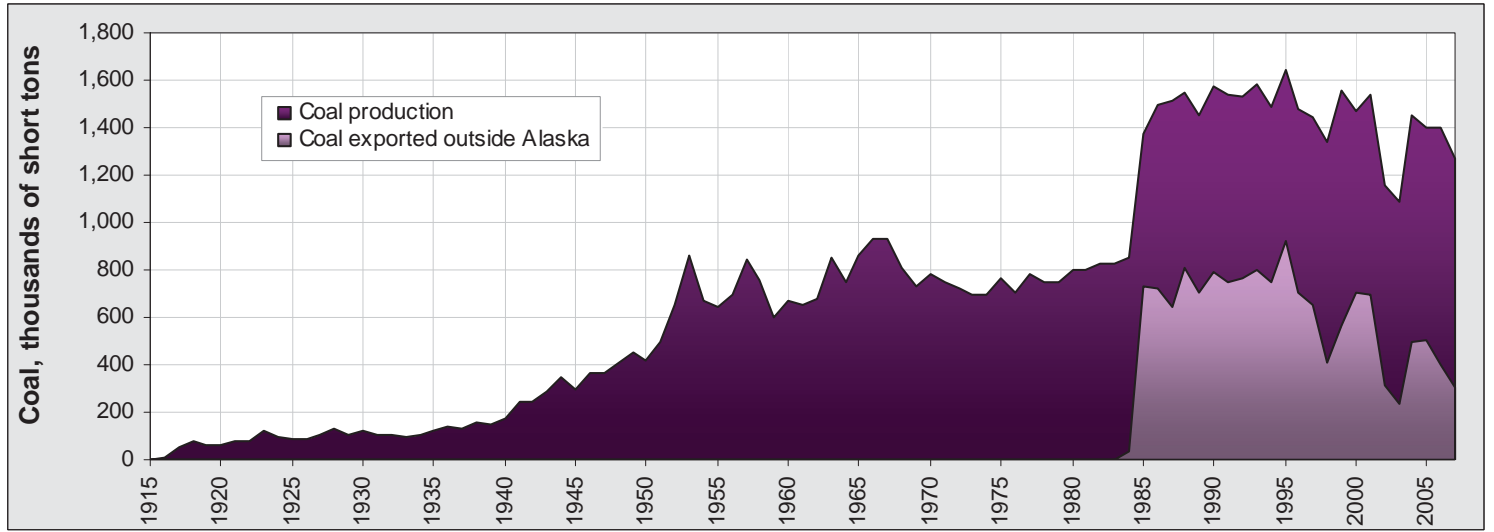

Figure 23. Coal production in Alaska, 1915-2007, including exports to Korea. 


\section{Northern Region}

1. Teck Cominco Alaska Inc. Red Dog Mine, Noatak district - zinc, lead, silver (germanium)

2. Placer gold mines

3. Prudhoe bay and Kuparuk pits (numerous) - sand and gravel

\section{Western Region}

4. Nome - Placer gold, sand and gravel

5. Placer gold mines

\section{Eastern Interior Region}

6. Placer gold mines

7. Polar Mining Inc., Fairbanks district - gold, silver, screened aggregate.

8. Fairbanks Gold Mining Inc., Ft. Knox - gold

9. Earthmovers of Fairbanks Inc. - Fairbanks district, gold

10. Teck Pogo Inc., Pogo Mine - Fairbanks district, gold

11. Usibelli Coal Mine Inc., Bonnifield district - coal

12. Placer gold mines

13. Placer gold mines

14. Placer gold mines

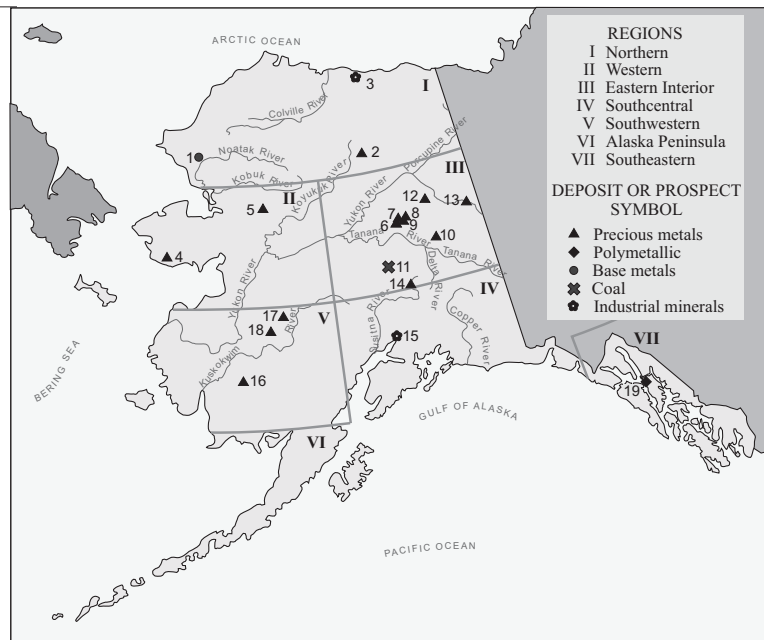

V Southwestern Region

16. NYAC Mining Co. - gold

17. Placer gold mines

18. Placer gold mines

\section{Alaska Peninsula Region}

\section{Southcentral Region}

15. Palmer/Wasilla - Anchorage district - sand and gravel

\section{Southeastern Region}

19. Kennecott Minerals Co/Hecla Mining Co., Greens Creek Mine, Juneau-Admiralty district - silver, zinc, gold, lead

Figure 24. Selected production projects, 2007.

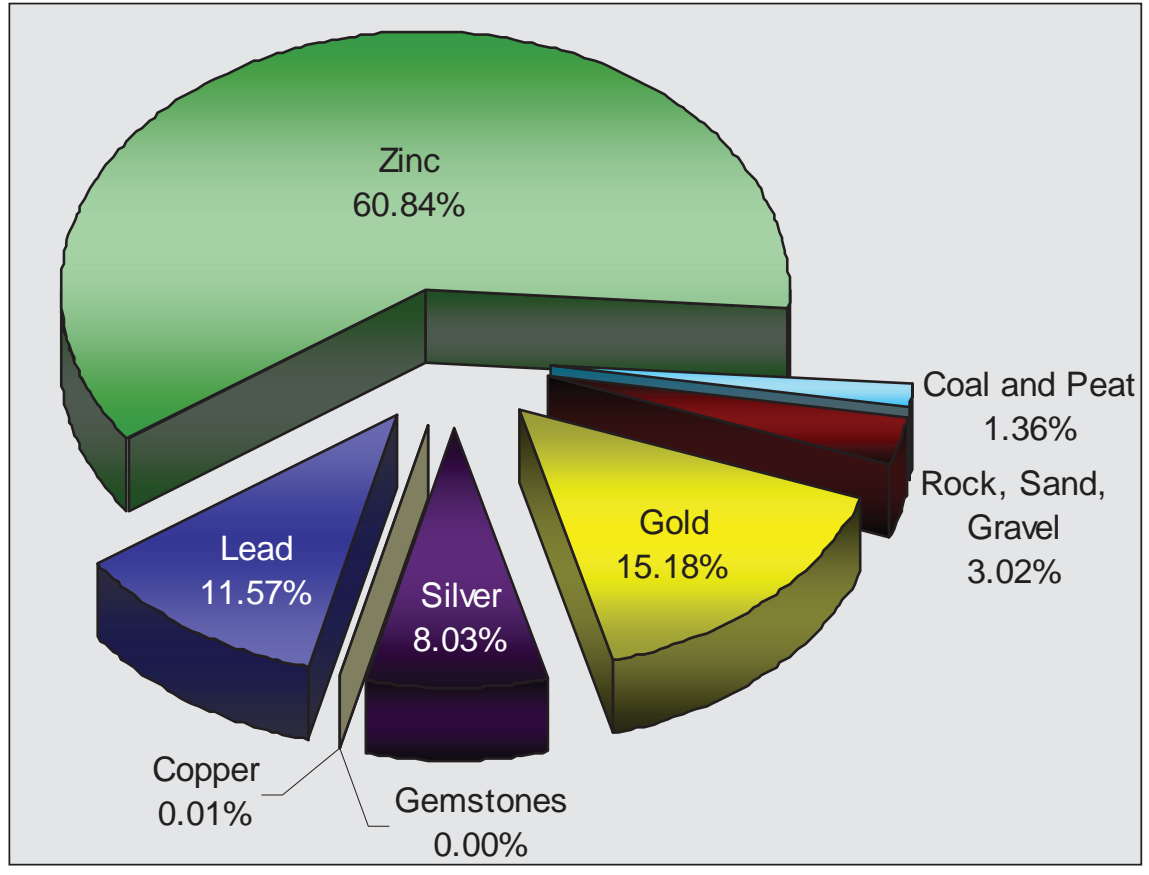

Figure 25. Alaska mineral production value by commodity. 
(11.77 percent), Fort Knox (6.99 percent), Pogo (5.53 percent), rock, sand and gravel (3.02 percent), coal and peat (1.32 percent), placer gold (1.11 percent), and the remaining ( 0.18 percent).

Table 12 shows the average metal values used in this report over the last 14 years. Some respondents reported unit values received for production and these actual values were used in place of the values in the table. In general, however, metal values were computed from weekly averages on the London Metal Exchange and do not take into account mining, shipping, smelting, and other costs incurred by the producer. All but zinc show an appreciation in price; zinc held even with its price in 2006. Percentage increases in metal prices from 2006 to 2007 were: gold, 15.2 percent; silver, 15.6 percent; copper, 7.14 percent; and lead, 100.9 percent.
The production estimates included in this report are from questionnaires returned by miners, mining companies, Native organizations, government agencies, municipalities, and service companies, complemented by telephone queries, emails, faxes, searches of annual reports, $10-\mathrm{K}$ reports, and news releases by producers. Additional information was derived from State of Alaska Annual Placer Mining Applications (APMA's) submitted to the Alaska Division of Mining, Land \& Water.

The authors wish to thank the Alaska Railroad Corp., the Alaska Mental Health Trust Land Office, the Alaska Department of Transportation \& Public Facilities, the Alaska Division of Mining, Land \& Water, municipalities, the U.S. Forest Service, the U.S. Bureau of Land Management, Native regional corporations, the City and Borough of Juneau, and the Alyeska Pipeline Service Co., for providing information for this section of the report.

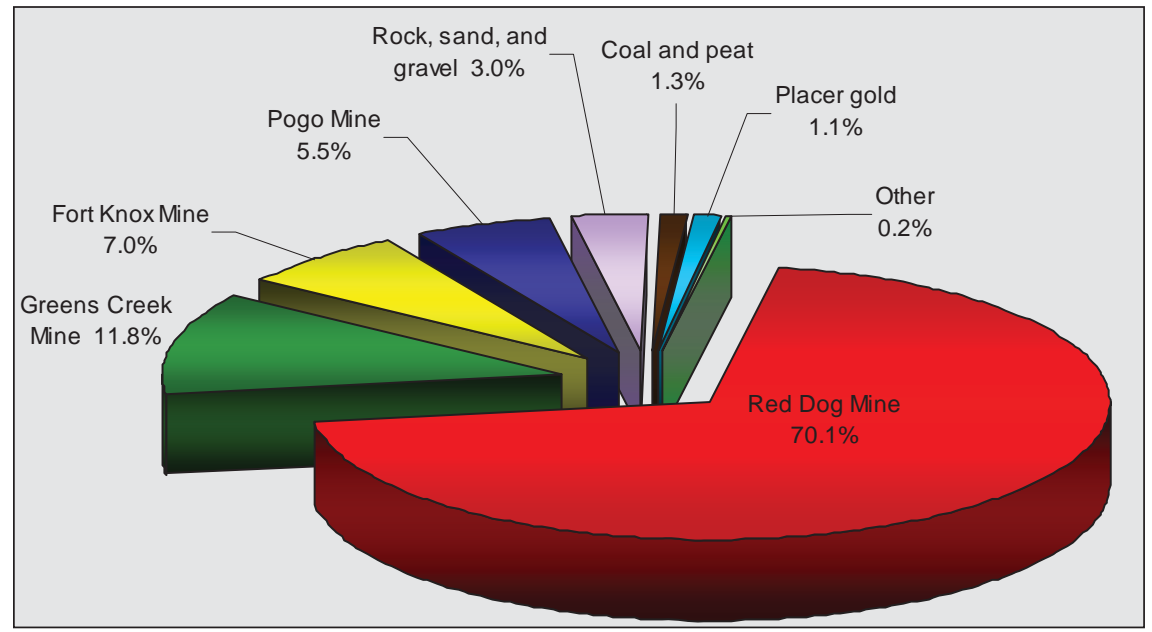

Figure 26. Alaska mineral production by mine or sector, 2007.

Table 12. Average metal prices, 1994-2007

\begin{tabular}{|c|c|c|c|c|c|c|c|c|c|c|}
\hline & \multirow[b]{2}{*}{$\begin{array}{c}\text { Gold } \\
\$ / o z \\
\end{array}$} & \multirow[b]{2}{*}{$\begin{array}{c}\text { Silver } \\
\$ / \mathbf{o z}\end{array}$} & \multirow[b]{2}{*}{$\begin{array}{c}\text { Copper } \\
\$ / l b\end{array}$} & \multirow[b]{2}{*}{$\begin{array}{c}\text { Lead } \\
\$ / l b\end{array}$} & \multirow[b]{2}{*}{$\begin{array}{l}\text { Zinc } \\
\$ / l b\end{array}$} & \multicolumn{5}{|c|}{ Percentage Change } \\
\hline & & & & & & Gold & Silver & Copper & Lead & Zinc \\
\hline 1994 & 386.00 & 5.41 & 1.05 & 0.35 & 0.45 & & & & & \\
\hline 1995 & 395.00 & 5.43 & 1.33 & 0.34 & 0.48 & 2.33 & 0.37 & 26.67 & -2.86 & 6.67 \\
\hline 1996 & 387.60 & 5.19 & 1.03 & 0.37 & 0.49 & -1.87 & -4.42 & -22.56 & 8.82 & 2.08 \\
\hline 1997 & 330.76 & 4.91 & 1.03 & 0.28 & 0.59 & -14.66 & -5.39 & 0.00 & -24.32 & 20.41 \\
\hline 1998 & 293.88 & 5.53 & 0.75 & 0.24 & 0.46 & -11.15 & 12.63 & -27.18 & -14.29 & -22.03 \\
\hline 1999 & 278.70 & 5.20 & 0.71 & 0.23 & 0.49 & -5.17 & -5.97 & -5.33 & -4.17 & 6.52 \\
\hline 2000 & 279.10 & 4.96 & 0.82 & 0.21 & 0.51 & 0.14 & -4.62 & 15.49 & -8.70 & 4.08 \\
\hline 2001 & 271.04 & 4.37 & 0.71 & 0.22 & 0.40 & -2.89 & -11.90 & -13.41 & 4.76 & -21.57 \\
\hline 2002 & 310.06 & 4.61 & 0.41 & 0.21 & 0.35 & 14.40 & 5.49 & 0.00 & -4.55 & -12.50 \\
\hline 2003 & 363.38 & 4.88 & 0.81 & 0.23 & 0.38 & 17.20 & 5.86 & 14.08 & 9.52 & 8.57 \\
\hline 2004 & 409.72 & 6.67 & 1.29 & 0.40 & 0.47 & 12.75 & 36.68 & 89.26 & 73.91 & 23.68 \\
\hline 2005 & 444.74 & 7.32 & 1.61 & 0.43 & 0.63 & 8.55 & 9.75 & 24.81 & 7.50 & 34.04 \\
\hline 2006 & 603.46 & 11.55 & 3.02 & 0.58 & 1.47 & 35.69 & 58.20 & 87.58 & 34.88 & 133.33 \\
\hline 2007 & 695.39 & 13.38 & 3.24 & 1.17 & 1.47 & 15.23 & 15.58 & 7.14 & 100.86 & 0.00 \\
\hline
\end{tabular}


Tables 13 and 14 show gold production by region of the state, and placer production by small, medium, and large-sized producers. Two placer operations achieved a "large-sized" rating. Hard-rock (lode) gold production increased 32.0 percent, from 509,747 ounces in 2006 to 673,084 ounces in 2007. Placer gold production appears to have decreased slightly from 60,382 in 2006 ounces to 53,849 ounces in 2007; the rapidly increasing operating costs have had a negative effect on operations. The increase in hard-rock production primarily reflects a higher output from Pogo Mine and some production from Nixon Fork Mine. Production of gold should increase again in 2008 with continued improvement at Pogo, commissioning of Rock Creek/Big Hurrah, and maintenance-level production from most other sources. The longer range forecast for gold production is very positive with new projects such as Donlin Creek, Kensington, Pebble, and other smaller hard-rock projects being explored.

Tables 15 and 16 show the value and regional importance of sand, gravel, and rock stockpiling and sales. Sales of sand and gravel in 2007 totaled 14.2 million tons, up slightly from 2006 at 14.0 million tons. Rock production was 2.2 million tons, down from 2.4 million tons in 2006. These numbers reflect some shortfall in reporting.

The export value of minerals was $\$ 1,317$ million for 2007, 10.12 percent higher than the 2006 total of $\$ 1,196$ million. Minerals exports for 2007 set a new record (table 17, fig. 27).

Table 13. Reported refined gold production, number of operators, and industry employment in Alaska, 2005$2007^{a}$

\begin{tabular}{|c|c|c|c|c|c|c|c|c|c|}
\hline \multirow[b]{2}{*}{ Region } & \multicolumn{3}{|c|}{ Number of operators } & \multicolumn{3}{|c|}{ Production in ounces } & \multicolumn{3}{|c|}{ Number of employees ${ }^{b}$} \\
\hline & 2005 & 2006 & 2007 & 2005 & 2006 & 2007 & 2005 & 2006 & 2007 \\
\hline Northern & 3 & 20 & 18 & 60 & 1,910 & 8,555 & 3 & 40 & 31 \\
\hline Western & 16 & 41 & 34 & 12,649 & 14,900 & 21,904 & 61 & 58 & 122 \\
\hline Eastern Interior & 37 & 100 & 97 & 339,414 & 474,900 & 621,784 & 453 & 821 & 858 \\
\hline Southcentral & 11 & 25 & 13 & 385 & 5,837 & 1,801 & 64 & 36 & 26 \\
\hline Southwestern & 3 & 9 & 12 & 1,511 & 8,773 & 4,714 & 14 & 25 & 25 \\
\hline Alaska Peninsula ${ }^{c}$ & - & 1 & 1 & - & - & - & - & - & - \\
\hline Southeastern $^{\mathrm{d}}$ & 2 & 5 & 3 & 73,014 & 63,809 & 68,173 & 252 & 255 & 283 \\
\hline TOTAL & 72 & 201 & 178 & 427,033 & 570,129 & 726,931 & 847 & 1,235 & 1,345 \\
\hline
\end{tabular}

a2007 production includes 673,084 ounces of gold from hardrock mines and 53,849 ounces of gold from placer sources.

b Includes recreation numbers (operators, ounces, employees) for 2006 and 2007 and is calculated on the basis of full-year employment. 'Production from this single source is combined with southwestern production for confidentiality purposes.

Includes employment figures from Greens Creek Mine, which is a polymetallic producer with a strong gold component.

Table 14. Production for selected Alaska placer gold mines, 2000-2007

\begin{tabular}{|c|c|c|c|c|c|c|c|c|}
\hline \multicolumn{9}{|c|}{ Number of Mines } \\
\hline Mine Size & 2000 & 2001 & 2002 & 2003 & 2004 & 2005 & 2006 & 2007 \\
\hline Small $^{\mathrm{a}}$ & 60 & 33 & 43 & 58 & 60 & 50 & 177 & 153 \\
\hline Medium $^{\mathrm{b}}$ & 14 & 5 & 4 & 4 & 5 & 20 & 21 & 19 \\
\hline $\operatorname{Large}^{c}$ & 4 & 4 & 2 & 2 & 3 & 1 & 3 & 2 \\
\hline TOTAL & 78 & 42 & 49 & 64 & 68 & 71 & 201 & 174 \\
\hline \multicolumn{9}{|c|}{ Production in Ounces $^{d}$} \\
\hline Small & 8,981 & 5,048 & 9,931 & 8,124 & 7,621 & 6,783 & 23,343 & 19,755 \\
\hline Medium & 15,186 & 6,234 & 4,739 & 4,976 & 4,504 & 17,822 & 22,144 & 23,366 \\
\hline Large & 22,147 & 11,559 & 7,711 & 10,500 & 15,950 & $--^{\mathrm{e}}$ & 14,895 & 10,728 \\
\hline TOTAL & 46,314 & 22,841 & 22,381 & 23,600 & 28,075 & 24,605 & 60,382 & 53,849 \\
\hline
\end{tabular}


Peat resources mined and sold amounted to 68,367 cubic yards in 2007 compared to 66,500 cubic yards in 2006. Again, reporting shortfalls are noted for this commodity.

\section{NORTHERN REGION}

The value of production of Alaska's minerals in the northern region is estimated at $\$ 2,371.7$ million and employment at 514 full-time-equivalent positions. Red Dog Mine dominated the production value and employment numbers. Placer gold, sand and gravel, and minor rock production were noted in the region.

Red Dog Mine near Kotzebue in northwestern Alaska is the world's largest zinc producer, and it continued to dominate Alaska's mineral production value. Red Dog
Mine accounted for more than 70 percent of the total value of Alaska's mineral production during the year. Red Dog Mine is 100 percent owned and operated by Teck Cominco Alaska Inc. under an agreement with NANA Regional Corp., a Native Alaskan regional corporation. The Red Dog deposit comprises a number of sedimentary-hosted exhalative (SEDEX) lead-zinc sulfide deposits hosted in Mississippian- to Pennsylvanian-age sedimentary rocks. The ore bodies are lens shaped and occur within structurally controlled (thrust fault) plates. The sulfide mineralization consists of semi-massive to massive sphalerite, pyrite, marcasite, and galena. The mining method employed is conventional drill and blast open-pit mining. The main pit has an expected life of 5 years at current rates of production (table 18).

Table 15. Reported sand and gravel production and industry employment in Alaska by region, 2007.

\begin{tabular}{|c|c|c|c|c|c|}
\hline Region & $\begin{array}{c}\text { Companies and } \\
\text { agencies reporting }\end{array}$ & Tons & $\begin{array}{l}\text { Estimated unit } \\
\text { value }(\$ / \text { ton })^{\mathbf{b}}\end{array}$ & $\begin{array}{l}\text { Total } \\
\text { value }\end{array}$ & $\begin{array}{l}\text { Estimated number } \\
\text { of employees }\end{array}$ \\
\hline Northern & 8 & $1,167,483$ & $\$ 5.48$ & $\$ 6,395,972$ & 24.9 \\
\hline Western & 8 & 601,645 & 5.97 & $3,591,680$ & 12.8 \\
\hline Eastern Interior & 24 & $4,398,849$ & 4.78 & $21,009,642$ & 94.0 \\
\hline Southcentral & 22 & $7,545,306$ & 5.68 & $42,820,231$ & 134.3 \\
\hline Southwestern & 4 & 319,950 & 5.35 & $1,711,602$ & 15.1 \\
\hline Alaska Peninsula & - - & - - & -- & - & - - \\
\hline Southeastern & 26 & 130,442 & 4.53 & 590,263 & 2.9 \\
\hline TOTAL & 92 & $14,163,675$ & $\$ 5.37$ & $\$ 76,119,390$ & 284.0 \\
\hline
\end{tabular}

$\overline{{ }^{a}}$ From returned questionnaires, telephone surveys, follow-up fax questionnaires, and e-mails to probable producers, etc. Data were also returned from the Alaska Railroad, Alyeska Pipeline Service Co., DML\&W, USFWS, USBLM, USFS, regional corporations, and others.

${ }^{b}$ Values are based on estimates from producers.

- - = Not Reported.

Table 16. Reported rock production and industry employment in Alaska by region, 2007 ${ }^{a}$

\begin{tabular}{|c|c|c|c|c|c|}
\hline Region & $\begin{array}{c}\text { Companies and } \\
\text { agencies reporting }^{\text {b }}\end{array}$ & Tons & $\begin{array}{c}\text { Estimated unit } \\
\text { value }(\$ / \text { ton })^{c}\end{array}$ & $\begin{array}{l}\text { Total } \\
\text { value }\end{array}$ & $\begin{array}{c}\text { Estimated number } \\
\text { of employees }\end{array}$ \\
\hline Northern & 2 & 90 & $\$ 20.00$ & $\$ 1,800$ & 0.1 \\
\hline Western & 4 & 177,161 & $\$ 12.14$ & $\$ 2,150,457$ & 1.5 \\
\hline Eastern Interior & 3 & 104,680 & $\$ 10.09$ & $\$ 1,056,160$ & 6.2 \\
\hline Southcentral & 5 & 198,583 & $\$ 11.09$ & $\$ 2,201,850$ & 18.1 \\
\hline Southwestern & 2 & 320,250 & $\$ 12.01$ & $\$ 3,846,600$ & 18.1 \\
\hline Alaska Peninsula & 0 & -- & - & - & - \\
\hline Southeastern & 9 & $1,411,190$ & $\$ 11.52$ & $\$ 16,252,908$ & 79.8 \\
\hline TOTAL & 25 & $2,211,954$ & $\$ 11.53$ & $\$ 25,509,775$ & 123.8 \\
\hline \multicolumn{6}{|c|}{$\begin{array}{l}\text { ancludes shot rock, crushed stone, D-1, riprap, and modest quantities of ornamental stone. } \\
\text { bFrom } 15 \text { returned DGGS questionnaires, more than } 100 \text { telephone surveys, follow-up fax questionnaires, more than } 100 \text { e-mails to probable } \\
\text { producers, etc. Data were also returned from the Alaska Railroad, Alyeska Pipeline Service Co., DML\&W, DOT\&PF, USFS, USBLM, } \\
\text { USFS, regional corporations, and others. } \\
\text { 'Values are based on estimates from producers, from historic records, etc. } \\
\text { - - = Not reported. }\end{array}$} \\
\hline
\end{tabular}


Additional reserves have been identified in the vicinity of the processing facilities sufficient to extend the life of the operation by 15 years for a total mine life of 23 years.

The mineral processing facilities employ conventional grinding and sulfide flotation methods to produce zinc and lead concentrates. The shipping season at Red Dog is restricted to approximately 100 days per year because of sea ice conditions, and Red Dog's sales are seasonal with the majority of sales in the last 5 months of each year. Concentrate is stockpiled at the port facility and is typically shipped between July and October.

Teck reported an operating profit at Red Dog Mine of $\$ 763.2$ million in 2007; this is down 19.8 percent from its 2006 profit, which was reported to be $\$ 951.5$ million. The project milled 3.73 million tons of ore with a zinc grade of 20.2 percent, lead grade of 6.1 percent, and silver of $3.1 \mathrm{oz} / \mathrm{ton}$ (table 19). The project produced 633,511 tons of zinc and 146,152 tons of lead, and was credited with an estimated 11.6 million ounces of silver in 2007.

The significant increase in Red Dog's cost of sales was mainly due to the change in the royalty regime that occurred in 2007, although fairly significant operating cost increases were also experienced. The royalty, in accordance with the operating agreement with NANA governing the Red Dog Mine, increased to 25 percent of net proceeds of production in the fourth quarter of 2006. The royalty had previously been 4.5 percent of net smelter returns. The increase is partially offset by a decline in the base on which royalties are calculated. Operating, distribution, selling, and management fees,

\begin{tabular}{cc}
$\begin{array}{c}\text { Table 17. Alaska international mineral } \\
\text { exports }^{a}\end{array}$ & \\
\hline & $\begin{array}{c}\text { Export value } \\
\text { (millions) }\end{array}$ \\
1996 & 249 \\
1997 & 369 \\
1998 & 317 \\
1999 & 359 \\
2000 & 293 \\
2001 & 329 \\
2002 & 380 \\
2003 & 414 \\
2004 & 505 \\
$2005^{\text {a }}$ & 603 \\
$2006^{\text {a }}$ & 1,196 \\
$2007^{\text {a }}$ & 1,317
\end{tabular}

Source: U.S. Census Bureau, Origin of Movement Series.

ancludes mineral $/$ metal ores and concentrates, coal, and unwrought, nonmonetary gold exports.

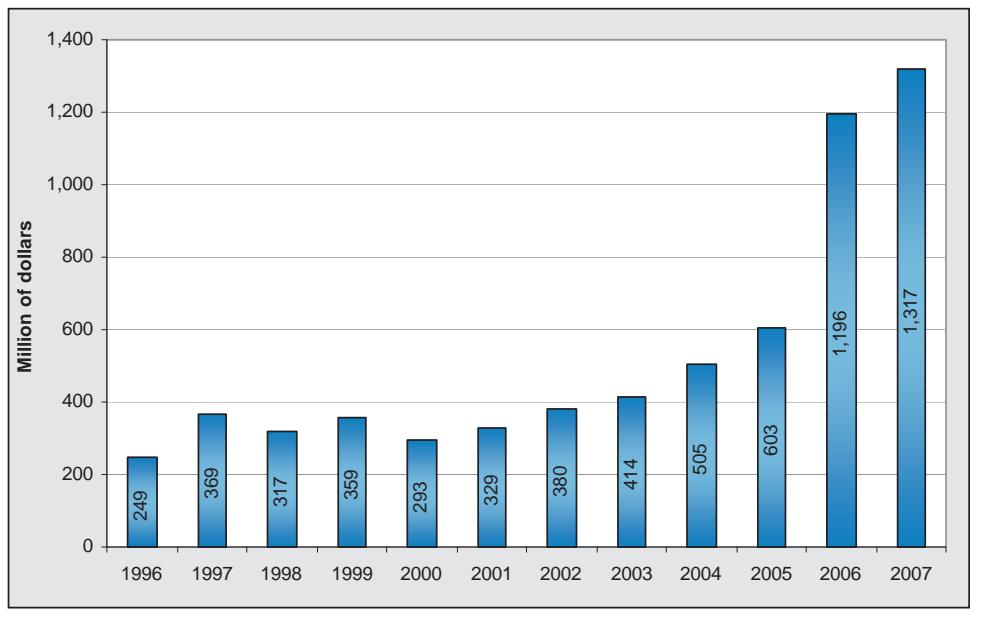

Figure 27. Alaska international mineral exports, 1996-2007.

Table 18. Reserves and resources by category at the Red Dog Mine as of December 31, 2007 (Teck Cominco Ltd. Annual report)

\begin{tabular}{lllrr}
\hline \multirow{2}{*}{ Class } & Metal & Category & $\begin{array}{c}\text { Tons, } \\
\text { millions }\end{array}$ & $\begin{array}{r}\text { Grade, } \\
\text { percent }\end{array}$ \\
\cline { 2 - 5 } Reserves & Zinc & Proven & 13.89 & 20.0 \\
& & Probable & 56.88 & 16.7 \\
& Lead & Proven & 13.89 & 5.5 \\
& & Probable & 56.88 & 4.4 \\
Resources & Zinc & Indicated & 6.72 & 19.5 \\
& & Inferred & 36.59 & 15.1 \\
& \multirow{2}{*}{ Lead } & Indicated & 6.72 & 6.6 \\
& & Inferred & 36.59 & 4.5
\end{tabular}


Table 19. Red Dog Mine production statistics, $1989-2007^{\circ}$

\begin{tabular}{|c|c|c|c|c|c|c|c|c|c|}
\hline & \multirow[b]{2}{*}{$\begin{array}{c}\text { Tons } \\
\text { milled }\end{array}$} & \multicolumn{3}{|c|}{ Ore Grade } & \multirow{2}{*}{$\begin{array}{c}\text { Total Tons } \\
\text { Concentrate } \\
\text { Produced }^{\mathbf{b}}\end{array}$} & \multirow{2}{*}{$\begin{array}{c}\text { Contained } \\
\text { Tons } \\
\text { Zinc } \\
\end{array}$} & \multirow{2}{*}{$\begin{array}{c}\text { Contained } \\
\text { Tons } \\
\text { Lead } \\
\end{array}$} & \multirow{2}{*}{$\begin{array}{l}\text { Million } \\
\text { Ounces } \\
\text { Silver }^{c} \\
\end{array}$} & \multirow[b]{2}{*}{ Employees } \\
\hline & & $\begin{array}{l}\text { Zinc } \\
(\%)\end{array}$ & $\begin{array}{c}\text { Lead } \\
(\%)\end{array}$ & $\begin{array}{c}\text { Silver } \\
\text { (oz/ton) }\end{array}$ & & & & & \\
\hline 1989 & 33,300 & 20.4 & 7.6 & 3.6 & 8,532 & -- & -- & -- & 228 \\
\hline 1990 & 996,700 & 26.5 & 8.5 & 3.6 & 443,600 & 191,981 & 31,187 & 1.60 & 350 \\
\hline 1991 & $1,599,300$ & 22.5 & 6.6 & 2.8 & 521,400 & 234,510 & 43,815 & 1.46 & 331 \\
\hline 1992 & $1,582,000$ & 19.9 & 6.0 & 2.9 & 474,900 & 231,363 & 15,960 & 1.38 & 349 \\
\hline 1993 & $1,874,600$ & 18.4 & 5.7 & 2.8 & 539,800 & 255,149 & 24,788 & 1.51 & 376 \\
\hline 1994 & $2,339,500$ & 18.8 & 5.7 & 2.8 & 658,000 & 328,160 & 32,775 & 1.84 & 391 \\
\hline 1995 & $2,485,900$ & 19.0 & 5.8 & 2.8 & 753,600 & 358,676 & 55,715 & 3.62 & 397 \\
\hline 1996 & $2,312,600$ & 18.7 & 5.0 & 2.8 & 765,300 & 357,680 & 65,886 & 4.30 & 417 \\
\hline 1997 & $2,127,000$ & 20.3 & 5.2 & 2.9 & 799,400 & 373,097 & 69,284 & 4.27 & 479 \\
\hline 1998 & $2,752,587$ & 21.4 & 5.2 & 2.7 & $1,015,773$ & 490,461 & 80,193 & 5.20 & 466 \\
\hline 1999 & $3,282,788$ & 21.3 & 5.2 & 2.7 & $1,207,160$ & 574,111 & 97,756 & 6.21 & 539 \\
\hline 2000 & $3,365,508$ & 21.0 & 4.7 & 2.5 & $1,211,539$ & 585,030 & 91,557 & 5.84 & 536 \\
\hline 2001 & $3,560,430$ & 19.8 & 5.0 & 2.5 & $1,215,837$ & 570,980 & 105,000 & 5.90 & 559 \\
\hline 2002 & $3,489,600$ & 21.1 & 5.4 & 2.7 & $1,366,480$ & 637,800 & 118,880 & 6.75 & 560 \\
\hline 2003 & $3,476,689$ & 21.7 & 6.2 & 3.1 & $1,397,246$ & 638,569 & 137,679 & 7.70 & 388 \\
\hline 2004 & $3,249,613$ & 22.0 & 6.0 & 3.0 & -- & 610,900 & 128,970 & 7.22 & 508 \\
\hline 2005 & $3,402,831$ & 21.7 & 5.6 & 3.0 & -- & 626,112 & 112,766 & 1.97 & 449 \\
\hline 2006 & $3,569,280$ & 20.6 & 6.1 & 3.0 & -- & 614,538 & 136,135 & 7.62 & 457 \\
\hline 2007 & $3,726,910$ & 20.2 & 6.1 & 3.1 & -- & 633,511 & 146,152 & 11.55 & 459 \\
\hline
\end{tabular}

an allowance for future reclamation and closure costs, capital costs, and deemed interest are deductible in the calculation of the royalty. The NANA royalty charge was $\$ 190$ million in 2007, compared with $\$ 57$ million in 2006. The net proceeds royalty will increase by 5 percent every fifth year to a maximum of 50 percent. The increase to 30 percent of net proceeds will occur in 2012. NANA shares approximately 62 percent of the royalty with other Alaskan Native corporations in accordance with 7(i) and (j) provision of $\mathrm{ANCSA}^{6}$.

Red Dog's location in northwestern Alaska exposes the operation to severe weather and winter ice conditions that can significantly impact its production volumes and operating costs. Supply deliveries and concentrate shipments occur during a short ocean shipping window, generally during the period early July to late October. During 2007 Red Dog's shipping season began on July 5,2007 , and was completed on October 24, 2007, with a total of 1,179,140 tons of zinc concentrate and 288,725 tons of lead concentrate shipped from the mine. Red Dog's sales volumes are normally higher in the last six months of the year than in the first six months, which can result in significant volatility in its earnings. Site operating costs increased 25 percent over 2006 due to higher sales volumes and a 9 percent increase in unit operating costs due to higher fuel, supplies, and labor costs. ${ }^{7}$
Employment at Red Dog during 2007 was 459 fulltime-equivalent positions, nearly the same as in 2006 . The mine provides direct employment for approximately 360 people. An additional 100 people work for either (1) NANA Management Services Inc., providing camp management, housekeeping, catering, and other services, or (2) NANA/Lynden LLC, hauling fuel, freight, and concentrate between the mine and port. More than 50 percent of the employees are NANA shareholders.

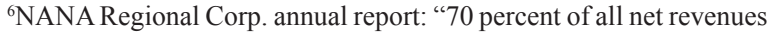
received by the Company for subsurface and timber resources transferred under the Act to the Company [NANA] must be distributed to all regional corporations, including itself (the funds are allocated based on the final number of Natives enrolled in each region in 1971); and similarly, the Company receives its pro-rata share of 70 percent of resources revenues received by the other 11 Native regional corporations which are recorded as revenues when the amount thereof is determined; of the 70 percent of the resource revenues of the Native regional corporations to which NANA is entitled, 50 percent of a portion of such revenues, which portion is based on the ratio of the nonvillage shareholders and enrolled village shareholders to total NANA shareholders, must be distributed to NANA's enrolled nonvillage shareholders and the Kikiktagruk Iñupiat Corporation. NANA retains the shares of such revenues that the merged village corporations would have been entitled to receive."

${ }^{7}$ Teck Cominco 2007 annual report.
} 
In the third quarter of 2007, the U.S. Environmental Protection Agency withdrew a recently-issued renewal of the Red Dog Mine's water discharge permit in the face of an appeal of the permit by a local community group and several environmental organizations. As a result, the permit renewal is expected to form part of the review and approval of a Supplemental Environmental Impact Statement (SEIS). The SEIS will focus on Red Dog's permit renewal and the projected impacts from mining the Aqqaluk deposit, which is the next ore body scheduled to be developed by Teck. Necessary authorizations must be in place prior to 2010 to ensure continuous operation of the mine at current production levels.

Silverado Gold Mine's Nolan Creek operation in the Alaska Range near Coldfoot produced 3,727 ounces of gold from 18,320 cubic yards mined from underground operations on Mary's Bench. The mine operates during the winter months in the frozen gravels to avoid thawing. The ore is stockpiled for summer washing and gold recovery. This is the only currently active underground placer mining operation in the state.

\section{WESTERN REGION}

Thirty-four placer operations, three recreational in size, reported production in the region for 2007. This is compared to 41 placer operations and five recreational for 2006. Reported production for 2007 was 21,904 ounces of gold compared to a production of 14,900 ounces in 2006. Placer gold employment in 2007 was estimated to be 122 persons compared to 58 for 2006 .

St. Andrew Goldfields Ltd. began mining operations at the Nixon Fork Mine near McGrath in the fourth quarter of 2006 after 3 years of exploration, engineering design, mining infrastructure rehabilitation, and permitting. Super sacks of concentrates are back-hauled from the mine site to Fairbanks and then transported by rail and barge to the Xstrata Copper Horne Smelter in Rouyn-Noranda, Quebec, Canada. For the 9 months that ended September 30, 2007, St. Andrew Goldfields achieved a head grade of 0.50 ounces per ton from the mining of 19,957 tons of ore from the upper portion of the 3300 zone of the Crystal deposit. The result is substantially different from the reserve head grade outlined in the independent technical report prepared for the Nixon Fork gold mine in October 2006. St. Andrew shut down its milling operations in August for about 6 weeks to modify its mill circuits. On October 10, 2007, the company announced the temporary suspension of production at the Nixon Fork gold mine to provide sufficient time to continue delineation drilling of the existing mineral resources and reserves in the $\mathrm{C} 3000$ and C3300 zones in the Crystal deposit in order to better define the irregular geometry of the gold mineralization for improved future mining recovery and dilution. The underground core drilling program is ongoing. In addition to the underground drilling program conducted during the winter of 2007, a surface drilling program is planned for spring 2008 at various locations along the approximately 2.5 -mile-long monzonite-limestone skarn contact zone where previous drilling has intersected a number of anomalous zones, namely the Mystery, J5A, Southern Cross, and Whalen zones that have potential to add to the current resource base. Production during the year amounted to 6,775 ounces of gold, 87,627 pounds of copper, and 3,739 ounces of silver. The mine has been placed up for sale. Employment at the project amounted to 69 for the year.

Sand and gravel production from the region was reported to be 601,645 tons from eight operations. Production in 2006 was 558,281 tons from eight operations. Employment in 2007 was estimated to be 12.8 full-timeequivalent jobs compared to 8.5 during 2006 .

Rock production from the region during 2007 was reported to be 177,161 tons from four operations. Production numbers for 2006 were estimated to be 52,271 tons from one operation. Full-time-equivalent jobs during 2007 were estimated to be 1.5 compared to 3.0 for 2006 .

\section{EASTERN INTERIOR REGION}

As in previous years, the Eastern Interior region was one of the most active regions during 2007. Fort Knox open-pit gold mine continued to be the leading producer in value of production and number of employees. Pogo Mine assumed commercial production during the year, but did not reach intended production goals. Total gold production from the region was 621,784 ounces. Lode gold (hard rock) production amounted to 598,279 ounces and placer gold production amounted to 23,505 ounces. Rock, sand, gravel, and peat production continued to be an important segment in the Interior.

Fort Knox gold mine, operated by Fairbanks Gold Mining Co., a wholly owned subsidiary of Kinross Gold Corp., produced 338,459 ounces of gold during 2007 (table 20). This is a 1.52 percent increase from 2006, when Fort Knox recorded 333,383 ounces of gold produced. Mill throughput for 2007 was 14,021,400 tons compared to $14,839,297$ tons in 2006 . Average recoverable grade was 0.0241 ounces per ton for 2007 compared to 0.0225 for 2006. Mining activity produced 45.98 million tons of material during the year, an average rate of 126,000 tons per day. All production was from phase 6 . Ore production averaged 60,300 tons per day in 2007 compared to an average of 33,900 tons during 2006; lower grade materials were stockpiled for future heap leaching. Waste stripping amounted to 23.92 million tons compared to 35.0 million tons during 2006. Total manpower for 2007 was 399 fulltime-equivalent persons. 
Pogo Mine is a joint venture with Sumitomo Metal Mining Co. Ltd (51 percent), Sumitomo Corp. (9 percent), and Teck Cominco Ltd. (40 percent). Teck Cominco is the operator of the mine, located 90 miles southeast of Fairbanks. The mine produced 715,665 tons of ore and processed 715,400 tons, out of which 259,820 ounces of gold was recovered during 2007 as opposed to a planned production of 340,000 ounces (table 21). Gold recovery was calculated to be 84.71 percent. The mine has not reached full capacity due to the construction and commissioning of the filter projects in the first quarter and poor equipment availability that impacted online time and throughput rates. The ore is extremely abrasive, and continuous improvement projects are focused on equipment reliability. Reduction of dilution in mining has been accomplished by using smaller equipment in narrow ore headings during the second half of 2007. Mill recoveries have improved and various upgrade projects are in progress, including automation of the flotation circuit, expected to be complete by the first half of 2008. Operating costs are high but improving; the average for 2007 was \$515 per ounce. Production for 2008 is expected to be between 340,000 and 360,000 ounces. Full-time-equivalent employment at year end was 251 mine employees and 88 contractor employees.
Usibelli Coal Mine continued production of sub-bituminous coal from its Two Bull Ridge mine site near Healy with an output of 1.357 million tons of coal. This was lower than in 2006 by about 43,000 tons. Shipments to Glencore International AG for Chile amounted to 308,146 tons. The mine also supplies six power plants in interior Alaska with approximately 900,000 tons of coal annually. Employment was 102 full-time-equivalent persons for the year.

Agrium continued to study its Blue Sky project for a coal gasification plant to feed the company's fertilizer plant on Alaska's Kenai Peninsula; Usibelli was involved by proposing to provide coal to this project. The plant was closed in December 2007 due to lack of natural gas feedstock. A preliminary engineering design for the coal gasification plant was completed during the year. Phase one was a feasibility study for the project; this was completed in August 2006. An announcement was released on March 13, 2008. The company found that the economics were not sufficient to proceed with a gasification facility, and the plant has been mothballed.

Placer gold production in 2007 from Interior mines amounted to 23,505 ounces from 95 operations of various sizes. Employment estimates for these operations amounts to 120 full-time-equivalent persons; previous

Table 20. Fort Knox Gold Mine production statistics, 1996-2007.

\begin{tabular}{|c|c|c|c|c|c|c|c|c|}
\hline & \multicolumn{3}{|c|}{ Tons Mined (ore + waste) } & \multicolumn{3}{|c|}{ Tons milled (ore) } & \multirow{2}{*}{$\begin{array}{c}\text { Ounces } \\
\text { Produced }\end{array}$} & \multirow{2}{*}{$\begin{array}{c}\text { Employ- } \\
\text { ment }\end{array}$} \\
\hline & Fort Knox & True North $^{\mathrm{a}}$ & Total & Fort Knox & True North ${ }^{\mathrm{a}}$ & Total & & \\
\hline 1996 & $16,684,000$ & & $16,684,000$ & 769,700 & & 769,700 & 16,085 & 243 \\
\hline 1997 & $32,380,000$ & & $32,380,000$ & $12,163,151$ & & $12,163,151$ & 366,223 & 249 \\
\hline 1998 & $33,294,000$ & & $33,294,000$ & $13,741,610$ & & $13,741,610$ & 365,320 & 245 \\
\hline 1999 & $30,350,000$ & & $30,350,000$ & $13,819,010$ & & $13,819,010$ & 351,120 & 253 \\
\hline 2000 & $35,600,000$ & & $35,600,000$ & $15,000,000$ & & $15,000,000$ & 362,929 & 253 \\
\hline 2001 & $25,957,900$ & $8,448,400$ & $34,406,300$ & $13,282,614$ & 2,377,386 & $15,660,000$ & 411,220 & 360 \\
\hline 2002 & $24,583,500$ & $11,461,000$ & $36,044,500$ & $11,887,200$ & $3,371,800$ & $15,259,000$ & 410,519 & 360 \\
\hline 2003 & $30,597,940$ & $12,707,100$ & $43,305,040$ & $11,473,000$ & $3,611,682$ & $15,084,682$ & 391,831 & 316 \\
\hline 2004 & $44,187,000$ & $3,763,000$ & $47,950,000$ & $12,917,966$ & $1,675,854$ & $14,593,820$ & 338,334 & 427 \\
\hline 2005 & $63,248,000$ & -- & $63,248,000$ & $14,384,842$ & - & $14,384,842$ & 329,320 & 411 \\
\hline 2006 & $51,070,000$ & - & $51,070,000$ & $14,839,297$ & - - & $14,839,297$ & 333,383 & 406 \\
\hline 2007 & $45,940,000$ & - & $45,940,000$ & $14,021,400$ & - & $14,021,400$ & 338,459 & 399 \\
\hline
\end{tabular}

Table 21. Pogo Mine production statistics, 2006-2007.

\begin{tabular}{|c|c|c|c|c|c|c|}
\hline & $\begin{array}{l}\text { Tons Ore } \\
\text { Mined }\end{array}$ & $\begin{array}{c}\text { Tons Ore } \\
\text { Milled }\end{array}$ & $\begin{array}{c}\text { Ounces of } \\
\text { Gold Recovered }\end{array}$ & $\begin{array}{l}\text { Head Grade } \\
\text { Recovery, \% }\end{array}$ & Oz/ton & Employees $^{a}$ \\
\hline 2006 & 447,129 & 338,000 & 113,364 & 85.0 & 0.395 & 477 \\
\hline 2007 & 715,665 & 715,400 & 259,820 & 84.4 & 0.430 & 339 \\
\hline
\end{tabular}


year production amounted to 28,153 ounces from 100 operations. Employment for 2006 was estimated at 118 persons.

Industrial minerals are an important sector in the Interior region and this activity continued during 2007. Sand and gravel production amounted to 4.4 million tons from 24 different operations compared to 1.16 million tons from 11 operators in 2006. Employment for these operations was approximately 94 persons compared to 100 full-time positions during 2006. Rock production amounted to approximately 105,000 tons and created 6.2 full-time positions for 2007 . This compares to 737,544 tons and 25 full-time positions for 2006. Peat production was reported to be 25,000 bank cubic yards for 2007 , the same as for 2006. Reporting shortfalls are noted in this commodity. Employment for the peat industry was estimated to be 3.7 persons for 2007 .

\section{SOUTHCENTRAL REGION}

Rock, sand, gravel, and peat (topsoil) continue to be the most valuable commodities produced for this region. The region was the largest producer of these products, even with only 31 operations reporting compared to 71 operations reporting for 2006. Sand and gravel production amounted to 7.55 million tons for the year, compared to 6.42 million tons for 2006. In 2007, sand and gravel provided an equivalent of 134 full-time jobs, compared to 105 for 2006 . Rock production in 2007 was 198,583 tons compared to 386,567 tons in 2006 . Rock production operators provided an equivalent of 18.1 full-time positions compared to 11 for 2006 . Reported peat production totaled 43,367 bank cubic yards compared to 41,500 in 2006. Reported full-time positions associated with peat production were 7, the same number as in 2006. Reporting shortfalls are fairly significant and could be up to 50 percent below actual numbers.

Placer gold production reported for this region during 2007 was 1,801 ounces compared to 5,837 for 2006 . A total of 13 operators reported placer gold production compared to 25 during 2006. Eight of the operators were recreational in size; this compares to 10 considered recreational in size in 2006. Total full-time-equivalent employment in 2007 amounted to 26 positions, compared to 36 for 2006. One full-time gemstone operator is included in the placer numbers and no segregation is provided for confidentiality reasons.

\section{SOUTHWESTERN REGION}

Placer gold production from the region during 2007 amounted to 4,714 ounces, compared to 8,706 ounces during 2006. Calculated full-time-equivalent employment was 25, the same as in 2006. Twelve operators reported production compared to 9 for 2006 . Three of the 2007 operations were considered recreational in size.
Rock, sand, and gravel production was reported from the southwestern region in 2007 compared to no reports in 2006. Sand and gravel production amounted to 319,950 tons and provided 15 full-time-equivalent jobs. Rock production amounted to 320,250 tons and provided 18 full-time-equivalent jobs. Four sand and gravel and 2 rock operations provided reports.

\section{ALASKA PENINSULA REGION}

No production was reported for any commodity during 2007, the same as in 2006. This is believed to be a reporting shortfall rather than a lack of production, particularly considering rock, sand, and gravel needs.

\section{SOUTHEASTERN REGION}

The southeastern region reported polymetallic, rock, sand, gravel, and placer gold production for 2007. Total minerals industry production employment for the region in 2007 was approximately 362 compared to 489 for 2006. The difference is believed to be reporting shortfalls in the rock, sand, and gravel sector.

Greens Creek Mine, a Kennecott Minerals Co.-Hecla Mining Co. joint venture in southeastern Alaska, is a polymetallic, volcanogenic massive sulfide deposit (silver, zinc, lead, gold, and copper) and considered the fifth largest silver producer in the world. It produces a silver-gold doré and sulfide concentrates containing zinc and lead. Greens Creek Mine was operated by Kennecott Minerals Co., which owned 70.3 percent; Hecla Mining Co. owned the remaining 29.7 percent. Kennecott and Hecla consummated an agreement to transfer full ownership to Hecla for $\$ 750$ million; the agreement was finalized on April 16, 2008, and Hecla has assumed operation and control of the mine. Greens Creek Mine has produced a total of about 150 million ounces of silver and approximately 1 million ounces of gold since 1987 and currently has 116 million ounces of silver reserves and resources, with a mine life to 2019.

Production at Greens Creek mill was almost the same as in 2006 (table 22). Mill throughput was 732,227 tons compared to a 2006 throughput of 732,176 tons. Metal production totaled $8,646,825$ ounces of silver, 68,006 ounces of gold, 62,603 tons of zinc, and 21,029 tons of lead. Production numbers for 2006 were 8,865,818 ounces of silver, 62,935 ounces of gold, 59,429 tons of zinc, and 20,992 tons of lead. Manpower numbers for 2007 were 321 full-time-equivalent persons, 45 of whom were reported in the development section of this report. The average grade of ore produced in 2007 was 9.67 percent zinc, 3.66 percent lead, 15.45 ounces of silver per ton, and 0.14 ounces of gold per ton.

Currently, Greens Creek is mining approximately 2,100 tons of ore per day from underground operations. Ore from the underground trackless mine is milled at 
the mine site. The mill produces gold doré from gravity concentrates, lead, zinc, and bulk concentrates. Generally, the mine ships concentrates to Korea, Japan, Mexico, and Canada for smelting and metals recovery. Gold doré produced from the gravity circuit is shipped to other points in the U.S. for refining; this accounts for approximately 20 percent of the recovered gold.

The Greens Creek Mine had year-end reserves and resources as shown in table 23.

Three placer gold operations reported production totaling 168 ounces of gold for 2007. Calculated employment was six full-time-equivalent positions. This compares to five operators reporting 874 ounces of production in 2006 with ten full-time-equivalent positions.

Rock, sand, and gravel operations in 2007 in the southeastern region produced 1.41 million tons of rock and 130,443 tons of sand and gravel. Nine rock producers and 26 sand and gravel producers reported. Production during 2006 was a total of 1.353 million tons, mostly rock. Total employment in 2007 was 80 compared to 68 during 2006 . This is the only region with a greater amount of rock produced than sand and gravel; all other regions have a higher sand and gravel to rock production ratio. Shortfalls in reporting are indicated.

Table 22. Greens Creek Mine production statistics, 1989-2007

\begin{tabular}{|c|c|c|c|c|c|c|c|c|}
\hline & \multirow[b]{2}{*}{$\begin{array}{c}\text { Tons } \\
\text { Milled }\end{array}$} & \multirow[b]{2}{*}{$\begin{array}{c}\text { Tons } \\
\text { Concentrate }\end{array}$} & \multicolumn{5}{|c|}{ Contained Metal } & \multirow[b]{2}{*}{ Employees } \\
\hline & & & $\begin{array}{l}\text { Tons } \\
\text { Zinc }\end{array}$ & $\begin{array}{l}\text { Tons } \\
\text { Lead }\end{array}$ & $\begin{array}{c}\text { Tons } \\
\text { Copper }^{\mathrm{a}}\end{array}$ & $\begin{array}{c}\text { Ounces } \\
\text { Gold }\end{array}$ & $\begin{array}{c}\text { Ounces } \\
\text { Silver }\end{array}$ & \\
\hline 1989 & 264,600 & - & 187,007 & 9,585 & - & 23,530 & $5,166,591$ & 235 \\
\hline 1990 & 382,574 & -- & 37,000 & 16,728 & - & 38,103 & $7,636,501$ & 265 \\
\hline 1991 & 380,000 & -- & 41,850 & 16,900 & -- & 37,000 & $7,600,000$ & 238 \\
\hline 1992 & 365,000 & 113,827 & 40,500 & 16,500 & - & 32,400 & $7,100,000$ & 217 \\
\hline $1993^{\mathrm{b}}$ & 77,780 & -- & 9,500 & 3,515 & -- & 7,350 & $1,721,878$ & 217 \\
\hline $1994^{c}$ & - - & -- & - - & - & -- & - & - - & - \\
\hline $1995^{\mathrm{c}}$ & -- & -- & - & -- & - & -- & - & -- \\
\hline $1996^{\mathrm{b}}$ & 135,000 & 43,000 & 9,100 & 4,200 & 193 & 7,480 & $2,476,000$ & 265 \\
\hline 1997 & 493,000 & -- & 46,000 & 19,000 & 1,300 & 56,000 & $9,700,000$ & 275 \\
\hline 1998 & 540,000 & - & 58,900 & 22,700 & 1,300 & 60,572 & $9,500,000$ & 275 \\
\hline 1999 & 578,358 & -- & 68,527 & 25,503 & 1,400 & 80,060 & $10,261,835$ & 275 \\
\hline 2000 & 619,438 & -- & 84,082 & 31,677 & 1,400 & 128,709 & $12,424,093$ & 275 \\
\hline 2001 & 658,000 & -- & 63,903 & 22,385 & 1,400 & 87,583 & $10,900,000$ & 275 \\
\hline 2002 & 733,507 & 217,200 & 80,306 & 27,582 & 1,600 & 102,694 & $10,913,183$ & 262 \\
\hline 2003 & 781,200 & -- & 76,200 & 24,800 & -- & 99,000 & $11,707,000$ & 295 \\
\hline 2004 & 805,789 & -- & 69,115 & 21,826 & -- & 86,000 & $9,707,000$ & 265 \\
\hline 2005 & 717,600 & -- & 58,350 & 18,600 & -- & 72,800 & $9,700,000$ & $265^{\mathrm{d}}$ \\
\hline 2006 & 732,176 & -- & 59,429 & 20,992 & -- & 62,935 & $8,865,818$ & $245^{\mathrm{e}}$ \\
\hline 2007 & 732,227 & -- & 62,603 & 21,029 & -- & 68,006 & $8,646,825$ & $276^{f}$ \\
\hline \multicolumn{9}{|c|}{$\begin{array}{l}\text { aNo copper credits in 1989-1993 and 2003-2007. } \\
\text { bPartial-year production. } \\
\text { 'No production in } 1994 \text { and } 1995 \text { due to mine closure. } \\
\text { dFifteen of these employees for } 2006 \text { were assigned to development effort. } \\
\text { 'Fifty employees were assigned to development and reported in that section's employment. } \\
\text { 'Forty-five employees were assigned to development and reported in that section's employment. } \\
\text { - - = Not reported. }\end{array}$} \\
\hline
\end{tabular}

Table 23. Reserves and resources by category at Greens Creek Mine as of December 31, 2007 (Hecla Mining Co. annual report)

\begin{tabular}{lrrrrr}
\hline & & \multicolumn{4}{c}{ Grade } \\
\cline { 3 - 6 } Class & Tons & $\begin{array}{c}\text { Silver } \\
\text { oz/ton }\end{array}$ & $\begin{array}{c}\text { Gold } \\
\text { oz/ton }\end{array}$ & $\begin{array}{c}\text { Lead } \\
\text { percent }\end{array}$ & $\begin{array}{c}\text { Zinc } \\
\text { percent }\end{array}$ \\
\cline { 2 - 6 } & & 13.7 & 0.11 & 3.8 & 10.2 \\
Probable Reserve & $8,455,096$ & 5.6 & 0.13 & 3.4 & 7.9 \\
Mineralized Material & 347,797 & 14.5 & 0.13 & 4.0 & 10.5 \\
Other Resources & $2,266,061$ & $\mathbf{1 3 . 6}$ & $\mathbf{0 . 1 1}$ & $\mathbf{3 . 8}$ & $\mathbf{1 0 . 2}$
\end{tabular}




\section{RECREATIONAL MINING}

Recreational mining continues to increase with the improved gold prices. Production numbers are not believed to be large and are very difficult to obtain; the identity of recreational miners is not sought from individuals and reporting is believed to be very inadequate. Reports are sought from commercial ventures, but returns are meager. Production numbers from this sector of the industry are reported in the placer gold production in tables 13 and 14. and are estimated to amount to 1,882 ounces for 2007 compared to 1,133 ounces for 2006 . Employment numbers provided in this report are educated guesses; they include commercial enterprise employees, miner time at the sites, and estimates of time involved by unorganized recreational miners in pursuit of the activity. The indicated full-time-equivalent jobs for 2007 were 55. Employment for 2006 was estimated at 45.

Steve Herschback, Alaska Mining and Diving, has provided an informative website to list recreational mining opportunities: www.akmining.com/mine/resites.htm. There are at least ten

Figure 28. A recreational placer miner feeds a high-banker sluice box on Chicken Creek. Photo courtesy of Chicken Gold Camp \& Outpost. commercial ventures that provide recreational mining opportunities (fig. 28). The ventures provide the right to mine along with varying degrees of services and facilities depending on the need, which in turn is driven by the remoteness of and access to the site. Charges for mining are moderate to high depending on the location and services provided. The website also lists other opportunities available to the recreational miner.

\section{DRILLING}

Drilling was conducted during all phases of mining (exploration, development, and production) on various projects across Alaska during the year. Table 24 lists companies with significant drilling programs in Alaska during 2007, and tables 25 and 26 summarize drilling activity in the state during 2007 by region and type of drilling. Drilling totals for 2007 are 830,478 feet of core drilling, 268,112 feet of reverse-circulation drilling, 50,539 feet of core and reverse-circulation drilling on coal operations, and 19,575 feet of placer auger/churn drilling. About 38 percent of the drilling footage for 2007 was from exploration projects in southwestern Alaska and 30 percent of the 2007 drilling footage was from exploration and development projects in the eastern Interior region of Alaska. The 2007 drilling footage increased almost 40 percent from the 2006 value, reflecting the substantial increase in exploration expenditures.

Major drilling programs were conducted in most areas of the state. Barrick Gold had the largest drill program in Alaska with more than 230,000 feet of core drilling on the Donlin Creek property. The largest programs were in southwestern Alaska, with drilling by Barrick Gold Inc. on the Donlin Creek property, Northern Dynasty Minerals Ltd. at the Pebble property, and International Tower Hill Mines Ltd. at the Terra property. Major drilling programs in southeastern Alaska were conducted by Kennecott Minerals Co. with surface and underground drilling at Greens Creek Mine, by Coeur Alaska Inc. at the Kensington and Jualin properties, by Niblack Mining Corp. on the Niblack property, and by Bravo Ventures Ltd. at several prospects on Woewodski Island. Major drilling programs were conducted in the eastern Interior region by Teck Pogo Inc. on the Pogo property and Rubicon Minerals Corp. in the Goodpaster mining district, by Kinross Gold Corp. near the Fort Knox Mine and by Freegold Ventures Ltd. on the Golden Summit property in the Fairbanks mining district, by Full Metal Minerals Ltd. in the Fortymile mining district, and 
International Tower Hill Mines Ltd. in the Livengood mining district. Little Squaw Mining Co. conducted a large reverse-circulation drilling program on the Little Squaw property in the Chandalar area (fig. 29) and Silverado Gold Mines Ltd. drilled placer and lode gold occurrences in the Nolan Creek area. In southcentral Alaska, major drilling programs were conducted by Full Metal Minerals Ltd. at the Lucky Shot property, by Geoinformatics Exploration Inc. at the Whistler property, and by Pure Nickel Inc. on the MAN property. NovaGold Resources Inc. drilled at the Rock Creek, Big Hurrah, and Arctic properties in the northern and western regions. St. Andrew Goldfields Ltd./Mystery Creek Resources Inc. continued underground drilling at the Nixon Fork property. Teck Cominco Alaska Inc. drilled in the Red Dog Mine area and drilled the Aqqaluk deposit to define mineral resources.

Table 24. Companies reporting significant drilling programs in Alaska, 2007

Altair Ventures Inc.

Andover Ventures Inc.

Barrick Gold Corp.

BHP Billiton Ltd.

Bravo Venture Group Inc.

Coeur Alaska Inc.

Constantine Metal Resources Ltd.

Freegold Ventures Ltd.

Full Metal Minerals Ltd.

Geoinformatics Exploration Inc.

Gold Crest Mines Inc.

International Tower Hill Mines Ltd.
Kennecott Minerals Co. \& Hecla Mining Co.

Kinross Gold Corp. (Fairbanks Gold Mining Inc.)

Little Squaw Mining Co.

Max Resource Corp.

Millrock Resources Inc.

Niblack Mining Corp.

Northern Dynasty Minerals Ltd.

NovaGold Resources Inc.

Pathfinder Mineral Services

Pure Nickel Inc.
Rubicon Minerals Corp.

Rhyolite Resources Ltd.

Silverado Gold Mines Ltd.

St. Andrew Goldfields Ltd. (Mystery

Creek Resources Inc.)

Teck Cominco Alaska Inc.

Teck Pogo Inc.

Triex Minerals Corp

Ucore Uranium Inc. \& Landmark

Minerals Inc.

Usibelli Coal Mine Inc.

Zazu Metals Corp.

Table 25. Drilling footage by region in Alaska, 2007

\begin{tabular}{|c|c|c|c|c|c|c|c|c|}
\hline Type of drilling & Northern & Western & $\begin{array}{l}\text { Eastern } \\
\text { interior }\end{array}$ & $\begin{array}{l}\text { South- } \\
\text { central }\end{array}$ & $\begin{array}{c}\text { South- } \\
\text { western }\end{array}$ & $\begin{array}{l}\text { South- } \\
\text { eastern }\end{array}$ & $\begin{array}{c}\text { Alaska } \\
\text { Peninsula }\end{array}$ & TOTAL \\
\hline Placer subtotal & 18,310 & 1,165 & - & 100 & - & -- & - & 19,575 \\
\hline Coal subtotal ${ }^{\mathrm{b}}$ & - - & - & - & - - & - & -- & - & - - \\
\hline Hardrock core & 93,927 & 45,212 & 118,253 & 72,314 & 413,615 & 87,157 & - & 830,478 \\
\hline Hardrock rotary & 12,514 & 41,878 & 232,269 & - - & 31,990 & -- & - & 318,651 \\
\hline Hardrock subtotal & 106,441 & 87,090 & 350,522 & 72,314 & 445,605 & 87,157 & - & $1,149,129$ \\
\hline TOTAL (feet) & 124,751 & 88,255 & 350,522 & 72,414 & 445,605 & 87,157 & - & $1,168,704$ \\
\hline
\end{tabular}

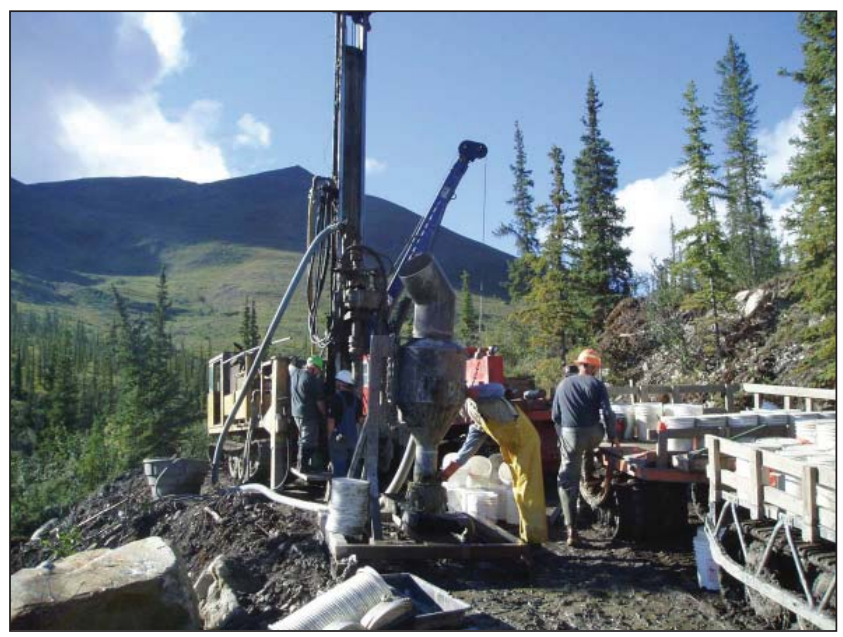

Figure 29. Lode drilling was conducted on Little Squaw Gold Mining Co.'s Chandalar property at the Summit prospect. Little Squaw also completed an extensive placer gold drilling program. Photo provided by Little Squaw Gold Mining Co. 
Table 26. Drilling footage reported in Alaska, 1982-2007

\begin{tabular}{|c|c|c|c|c|c|c|c|c|}
\hline Year & $\begin{array}{c}\text { Placer } \\
\text { Exploration }\end{array}$ & $\begin{array}{l}\text { Placer } \\
\text { Thawing }\end{array}$ & $\begin{array}{c}\text { TOTAL } \\
\text { PLACER }\end{array}$ & $\begin{array}{c}\text { TOTAL } \\
\text { COAL }\end{array}$ & $\begin{array}{c}\text { TOTAL } \\
\text { HARDROCK }\end{array}$ & $\begin{array}{c}\text { Hardrock } \\
\text { Core }^{\mathrm{a}}\end{array}$ & $\begin{array}{c}\text { Hardrock } \\
\text { Rotary }^{\mathrm{a}}\end{array}$ & $\begin{array}{c}\text { TOTAL } \\
\text { FEET }\end{array}$ \\
\hline 1982 & 30,000 & 94,000 & 124,000 & 80,000 & 200,000 & - - & - & 404,000 \\
\hline 1983 & 23,000 & 30,000 & 53,000 & 12,000 & 180,500 & - - & - - & 245,500 \\
\hline 1984 & 31,000 & 98,000 & 129,000 & 25,700 & 176,000 & - - & - - & 330,700 \\
\hline 1985 & 46,000 & 34,000 & 80,000 & 8,700 & 131,700 & - - & - - & 220,400 \\
\hline 1986 & 32,400 & 227,000 & 259,400 & 28,800 & 50,200 & - & - & 338,400 \\
\hline 1987 & 50,250 & 130,000 & 180,250 & 19,900 & 115,100 & 95,600 & 19,500 & 315,250 \\
\hline 1988 & 152,000 & 300,000 & 452,000 & 26,150 & 353,860 & 223,630 & 130,230 & 832,010 \\
\hline 1989 & 97,250 & 210,000 & 307,250 & 38,670 & 332,230 & 242,440 & 89,790 & 678,150 \\
\hline 1990 & 78,930 & 105,000 & 183,930 & 18,195 & 760,955 & 648,600 & 112,355 & 963,080 \\
\hline 1991 & 51,247 & 130,000 & 181,247 & 16,894 & 316,655 & 205,805 & 110,850 & 514,796 \\
\hline 1992 & 6,740 & 65,000 & 71,740 & 12,875 & 359,834 & 211,812 & 148,022 & 444,449 \\
\hline 1993 & 25,216 & - & 25,216 & - & 252,315 & 124,325 & 127,990 & 277,531 \\
\hline 1994 & 21,000 & - & 21,000 & 8,168 & 438,710 & 347,018 & 91,692 & 467,878 \\
\hline 1995 & 27,570 & - & 27,570 & - - & 415,485 & 363,690 & 51,795 & 443,055 \\
\hline 1996 & 61,780 & - - & 61,780 & 8,500 & 658,857 & 524,330 & 134,527 & 729,137 \\
\hline 1997 & 38,980 & - - & 38,980 & 13,998 & 704,510 & 523,676 & 180,834 & 757,488 \\
\hline 1998 & 33,250 & - & 33,250 & 2,300 & 551,078 & 505,408 & 45,670 & 586,628 \\
\hline 1999 & 6,727 & - & 6,727 & - - & 448,797 & 369,863 & 78,934 & 455,524 \\
\hline 2000 & 15,480 & - - & 15,480 & - & 546,268 & 418,630 & 127,638 & 561,748 \\
\hline 2001 & 1,100 & - & 1,100 & 36,151 & 316,068 & 240,318 & 75,750 & 353,319 \\
\hline 2002 & 1,250 & - & 1,250 & - & 488,902 & 385,290 & 103,612 & 490,152 \\
\hline 2003 & 10,108 & - & 10,108 & 2,000 & 370,634 & 270,456 & 100,178 & 382,742 \\
\hline 2004 & 107,526 & - - & 107,526 & - - & 451,652 & 415,628 & 36,024 & 559,178 \\
\hline 2005 & 3,360 & - & 3,360 & - & 634,277 & 592,497 & 41,780 & 637,637 \\
\hline 2006 & 8,759 & - - & 8,759 & 7,500 & 819,536 & 765,363 & 54,173 & 835,795 \\
\hline 2007 & 19,575 & - & 19,575 & 50,539 & $1,098,590$ & 865,479 & 268,112 & $1,168,704$ \\
\hline
\end{tabular}

\section{GOVERNMENT ACTIONS}

Geologists from the Minerals Resources Section of the Alaska Division of Geological \& Geophysical Surveys (DGGS) mapped and sampled 189 square miles of the northeastern part of the Fairbanks mining district. A series of 1:50,000-scale geologic maps will be available in late 2008. This fieldwork is part of an integrated program following the airborne geophysical survey results previously released by DGGS in 2006.

DGGS also conducted geologic field work along the proposed gas pipeline corridor between Delta Junction and Dot Lake along the Alaska Highway during the summers of 2006 and 2007 (fig. 30). Surficial and bedrock mapping were completed at a scale of 1:63,360. In 2007 DGGS surficial geologists and contractors dug and logged several trenches to determine whether recent surface deposits have been offset by fault movement. Work in 2008 will continue this project from Dot Lake to Tetlin Junction.
The State of Alaska, through DGGS, funded and acquired airborne magnetic and electromagnetic geophysical surveys for 180 square miles of the 715-square-mile Styx River survey area in the northeastern Lime Hills and northwestern Tyonek quadrangles. The remainder of the data was to be acquired in early 2008 and released in summer 2008. DGGS also released airborne magnetic and electromagnetic geophysical survey data for 602 square miles of the eastern Bonnifield district along the northern flank of the Alaska Range. The surveys were conducted by Fugro Airborne Surveys Corp. and managed by Stevens Exploration Management Corp. These data, along with all historic DGGS publications and most U.S. Geological Survey publications on Alaska, are available for free download at the DGGS website (http://www. dggs.dnr.state.ak.us).

To date, with an investment of $\$ 9.6$ million, almost 9 million acres (more than 14,000 square miles) of 
Alaska have been flown for detailed geophysical surveys and about 2.7 million acres of 1:63,360and 1:50,000-scale geologic maps have been produced as part of the State-funded Alaska Airborne Geophysical/Geological Mineral Inventory (AGGMI) Program and state-funded Alaska Highway Corridor Study (table 27). Federal monies from the U.S. Geological Survey's STATEMAP Program fund some geologic mapping within the AGGMI Program.

DGGS also acquired airborne magnetic and electromagnetic geophysical data for a 250-square-mile area of the western Fortymile mining district. The survey, funded by the U.S. Bureau of Land Management, covers parts of the Eagle and Tanacross quadrangles and focuses on federal and Native lands. Table 28 shows the geophysical surveys flown in Alaska that were funded largely by federal monies through the U.S. Bureau of Land Management.

DGGS requested input from the Alaska mineral industry for the formation of a voluntary sponsor group to help financially support DGGS's mineral-resource programs. This program would be modeled after the successful energy industry sponsorship program for DGGS's energy-related field studies and supporting analyses. These programs allow increased footprint of mapped areas and provide an efficient means of optimizing the State's goal of providing pertinent high-resolution information on potentially developable resources.

The DGGS Geologic Materials Center (GMC) received mineral industry samples and data during the year. The U. S. Bureau of Land Management deposited nickel-copper-cobalt mineral core from the U. S. Bureau of Mines Funter Bay Hole No. 1 (44 boxes of core, total depth of hole was 443 feet) in the Juneau Quadrangle.

Governor Sarah Palin met with Cynthia Carroll, Anglo American PLC chief executive, to discuss issues surrounding the Pebble project. Anglo American executives also met with select state lawmakers. Ms. Carroll pledged that Anglo American would drop out of the deal on the Pebble project if the wild salmon fisheries of Bristol Bay could not be protected. Ms. Carroll promised to hire locally and set up various social and education programs in the Bristol Bay region. Anglo American set up a partnership with local residents, referred to as the Bristol Bay Sustainable Fisheries Fund, to enhance the Bristol Bay fishery.

Usibelli Coal Mine Inc. was named exporter of the year by Governor Sarah Palin for its work shipping coal to South Korea and Chile.

Alaska Industrial Development \& Export Authority (AIDEA) signed a 7-year agreement with Sherwood Copper Corp. in January to use the Skagway ore terminal for copper-gold ore concentrates from Sherwood's Minto Mine in the Yukon Territory, Canada. The agreement allows additional users of the terminal. After the agreement was signed, AIDEA awarded a facilities rehabilitation contract to construct a new concentrate storage building and support structures to handle Sherwood's copper concentrates. The Skagway ore terminal began receiving truckloads of high-grade copper-gold concentrates in July.

The price of State of Alaska-owned sand and gravel on the North Slope and on the state road system will climb from $\$ 1$ to $\$ 3$ per cubic yard. The price of overburden will also increase. The price of riprap, larger rocks used for embankments, will climb to $\$ 7.50$ per cubic yard from $\$ 2.50$ per cubic yard. The Alaska Department of Natural Resources adjusted the prices, last adjusted 
in 1999, to reflect the fair market value of the materials. North Slope oil companies are the largest consumer of state materials, followed by the Alaska Department of Transportation \& Public Facilities.

Beginning in 2007, Mining Licenses will be issued by the Alaska Department of Revenue (DOR) instead of the Alaska Department of Natural Resources (DNR). Information from an Annual Placer Mining Application (APMA) will be forwarded from DNR to DOR for DOR to issue a license. A form applying for a Mining License can also be submitted directly to DOR. A Mining License Tax return must be filed by previous owners of a Mining License before a new Mining License will be issued by DOR. The production royalty for mining on State of Alaska mining claims is calculated based on the Mining License Tax return. Royalties are due to the State even if no taxes are owed by a mining operation and the penalty for failure to pay the state royalty is claim forfeiture.

The Alaska Department of Natural Resources Water Section began requiring a temporary water permit use for

Table 27. Detailed state airborne geophysical surveys and follow-up geologic ground-truth mapping as of December $2007^{a}$

Nome District western core area

Nyac District core area

Circle District core area

Valdez Creek District

Fairbanks District

Richardson District

Rampart/Manley-Tofty

Upper Chulitna District

Petersville-Collinsville District

Iron Creek District

Ruby District

Fortymile District

Livengood District

Salcha River/North Pogo

Southeast extension of Salcha River-Pogo

Liberty Bell

Broad Pass

Council

Goodpaster River

Liscum $^{b}$

Black Mountain

East Richardson

Northeast Fairbanks

Alaska Highway Corridor ${ }^{c}$

Bonnifield District

Styx River (eastern portion)

Styx River (southern and western portions) ${ }^{\mathrm{d}}$
494 sq. miles 183 sq. miles 338 sq. miles 78 sq. miles 626 sq. miles 137 sq. miles

1,017 sq. miles 364 sq. miles 415 sq. miles 689 sq. miles 591 sq. miles 1,036 sq. miles 229 sq. miles

1,032 sq. miles 91 sq. miles 276 sq. miles 304 sq. miles 618 sq. miles 210 sq. miles 67 sq. miles 222 sq. miles 224 sq. miles 404 sq. miles

3,045 sq. miles

602 sq. miles 180 sq. miles 535 sq. miles
Airborne geophysical/ground-truth geological map

Airborne aeromagnetic mapping

Airborne geophysical mapping/ground-truth geologic map Airborne geophysical mapping

Airborne geophysical mapping/ground-truth geologic map Airborne geophysical mapping

Airborne geophysical mapping/ground-truth geologic map Airborne geophysical mapping/ground-truth geologic map Airborne geophysical mapping/ground-truth geologic map Airborne geophysical mapping/ground-truth geologic map Airborne geophysical mapping/ground-truth geologic map Airborne geophysical mapping/ground-truth geologic maps Airborne geophysical mapping/ground-truth geologic maps Airborne geophysical mapping/ground-truth geologic maps Airborne geophysical mapping

Airborne geophysical mapping/ground-truth geologic map Airborne geophysical mapping

Airborne geophysical mapping/ground-truth geologic map Airborne geophysical mapping

Airborne geophysical mapping

Airborne geophysical mapping

Airborne geophysical mapping

Airborne geophysical mapping/ground-truth geologic mapping

Airborne geophysical mapping/ground-truth geologic mapping

Airborne geophysical mapping (released winter 2007)

Airborne geophysical mapping (to be released winter 2008)

Airborne geophysical mapping (to be released summer 2008)

\section{Total: 15 years $\quad \$ 9.6$ million $\quad 14,007$ sq. miles $\quad 2.45 \%$ of Alaska's total area}

$\overline{\text { Projects funded }}$ by the Alaska State Legislature. Projects concentrate on state, Native, state-selected, and Native-selected lands and are managed by DGGS.

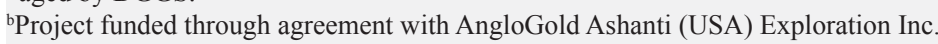

'Project funded by the Alaska State Legislature as a \$2 million Capital Improvement Project to assess the geologic hazards and resource potential along the proposed natural gas pipeline corridor.

dProject partially funded through agreement with Anglo American Exploration (USA) Inc. under the DGGS Mineral Industry Sponsorship Program.

Note: Surveys listed above are complete except where noted. Additional areas will be scheduled for surveying at later dates contingent on future funding. 
Table 28. Detailed federally funded airborne geophysical survey work as of December $2007^{a}$

\begin{tabular}{|c|c|c|}
\hline Wrangell/Stikine ${ }^{\mathrm{b}}$ & 1,111 sq. miles & Airborne geophysical mapping \\
\hline Koyukuk/Wiseman & 533 sq. miles & Airborne geophysical mapping \\
\hline Ketchikan $^{\mathrm{c}}$ & 605 sq. miles & Airborne geophysical mapping \\
\hline Aniak & 1,240 sq. miles & Airborne geophysical mapping \\
\hline Delta River & 603 sq. miles & Airborne geophysical mapping \\
\hline Sleetmute & 641 sq. miles & Airborne geophysical mapping \\
\hline Howard Pass - Misheguk Mountain & 1,447 sq. miles & Airborne geophysical mapping (released 2006) \\
\hline Western Fortymile & 250 sq. miles & Airborne geophysical mapping (to be released 2008) \\
\hline$\$ 4.0$ million & 6,430 sq. miles & $1.1 \%$ of Alaska's total area \\
\hline
\end{tabular}

drilling in 2007. Drills using more than 500 gallons per day for more than 10 days, or more than 5,000 gallons per day are required by regulation to have a temporary use permit. Core drills typically have a supply pump operating at 5,000 to 12,000 gallons per day per drill and the use is considered "consumptive" even if the water spills unused from the supply tank. The temporary water use permit is triggered when DNR receives the APMA application. A temporary water use permit can use up to five sources (stream reach or waterbody) and last up to 5 years. For those conducting drilling as a generally allowed use (less than 300 foot depth) and therefore not requiring an APMA, the operator should apply directly to the DNR Water Section for the water-use permit.

The State of Alaska established clear ownership of two historic RS 2477 trails in northern Alaska under a settlement reached with the federal government and Doyon Ltd. The 65-mile Coldfoot-Chandalar Lake trail and the 85-mile Caro-to-Coldfoot trail are among many access routes that Alaska claims under RS 2477, a federal law by which the federal government granted rights-of-way across federal lands not otherwise reserved for public use.

The U.S. Environmental Protection Agency (EPA) withdrew the Red Dog Mine's water discharge permit in October 2007. The EPA said its analysis for the permit issued in March 2007 was partially flawed because it used historical assumptions rather than current data on water use and dust emissions at the mine. The EPA will merge its review of the water permit with an environmental-impact analysis for the Red Dog Mine expansion to the Aqqaluk deposit.

The Alaska Railroad made $\$ 16.3$ million in net income during 2007 from total revenue of $\$ 169.3$ million. Freight amounted to $\$ 91.8$ million of the total, with mineral products (coal, sand, and gravel) revenue amounting to $\$ 14.8$ million, 16.3 percent of total rev- enues for the year. Mineral products revenue was down in 2007compared to 2006 at $\$ 17.8$ million, or 16.6 percent. Total freight tonnage, the railroad's core business, was 6.1 million tons including 2.4 million tons of gravel. The railroad also developed a quarry in the Curry area of southcentral Alaska that provides ballast for its capital program.

The Ninth U.S. Circuit Court of Appeals ruled that the Kensington project wastewater discharge permit issued by U.S. Army Corps of Engineers violated the federal Clean Water Act. The court found that the Corps of Engineers did not have the jurisdiction to grant the permit, with that authority resting with the U.S. Environmental Protection Agency. The appeals court sent the case back to a lower court to vacate the tailings permit, as well as a permit to build a marine terminal to service the mine. The case will likely be petitioned to the U.S. Supreme Court.

Funding for the U.S. Bureau of Land Management's (BLM) Alaska Minerals Program, which included the Juneau John Rishel Mineral Information Center (JRMIC) on Mayflower Island in Douglas, Alaska, was not included in the BLM budget for 2008. The doors to the JRMIC officially closed to the public July 20, 2007. The U.S. Coast Guard moved into the building. The JRMIC housed a specialized mining and geology library with a collection of more than 20,000 mineral-related items, including books, journals, maps, and state and federal government documents. Most office furniture and outdoor equipment was sent to the BLM's Campbell Tract warehouse in Anchorage for processing. Mining artifacts were transferred to the Juneau-Douglas City Museum, and will be identified by a commemorative plaque recognizing the John Rishel collection. The world-class mineral collection was transferred to the University of Alaska Anchorage, one of the only facilities in the state with room to display the complete collection. Records 
and books were transferred to the Alaska Resources Library and Information Services (ARLIS) in Anchorage and the Alaska Division of Geological \& Geophysical Surveys (DGGS) in Fairbanks. Effort was made to keep information specific to southeastern Alaska available in Juneau libraries. The information will remain accessible to the public.

The Jack Wade Dredge at Mile 86 of the Taylor Highway in eastern Alaska was dismantled by a contractor for the U.S. BLM due to safety concerns. The dredge, a popular tourist photo stop and one of the few indications of the rich placer mining history of the Fortymile area, had deteriorated over the years since being abandoned in 1941. Several large pieces of the dredge, such as the boiler, gearing and winching machinery, trommel, hand-levels, and buckets, were saved and will be put on display with some interpretive signs near the Chicken post office to highlight the historical significance of the dredge and placer gold mining in the region. The rest of the dredge was hauled to a landfill in Tok.

The BLM announced final results from the Bay Area Resource Management Plan/Environmental Impact Statement (RMP/EIS) update review. The BLM plans to lift mining restrictions on roughly 1 million acres of land in the Bristol Bay region. Mining restrictions have been in place for more than 30 years due to the land selection process imposed by the 1971 Alaska Native Claims Settlement Act (ANILCA).

The University of Alaska's Mining and Petroleum Training Service (MAPTS) opened a new training facility at Kenai Peninsula College in Soldotna. MAPTS was established 28 years ago and currently has the largest enrollment of any such program in North America. MAPTS has trained more than 50,000 people in mining technology, process technology, industrial process instrumentation, and mechanical technology.

\section{OUTLOOK}

Exploration activity appears to remain as robust as or stronger than the 2007 activity. Exploration expenditures are projected to remain high, but decrease from the record 2007 value. The Pebble and Donlin Creek projects will account for a large portion of the expenditures, as these projects approach feasibility studies. Several projects across the state are expected to have significant exploration expenditures in 2008 to define discoveries made over the past several years. Many exploration projects that have lain dormant for years are being explored again and reconnaissance-level exploration programs have outlined new prospects across Alaska.

Development expenditures for 2008 will be lower than in 2007 due to completion of most of the initial development of projects and delays in commissioning new projects. Construction at Rock Creek and Big Hurrah should be completed during 2008; construction is in final stages and should be completed in the latter part of 2008. Coeur Alaska has completed construction of its underground development, mill, and surface facilities with the exception of the tailings facilities at Kensington. A Modified Plan of Operations to the U.S. Forest Service for an alternative tailings facility is on track to receive the necessary permits later this year. Additionally, on June 27, the U. S. Supreme Court granted the State of Alaska and Coeur Alaska's Petitions for a Writ of Certiorari to review a Ninth Circuit Court of Appeals decision relating to the Kensington 404 permit. The final Supreme Court decision or approval of alternative tailings permitting may allow for construction to take place next year, leading to potential production in the latter part of 2009. The only possible development expenditures here would be for tailings facility construction in 2008/09. Kinross is continuing development of its heap leach facility and undertaking advanced stripping at Fort Knox Mine. The Chuitna coal project should continue at the current rate of expenditure. Ongoing capital maintenance and development expenditures will continue at Greens Creek and Red Dog mines. This indicates that development expenditures will be on the order of $\$ 200$ million compared to \$319 million for 2007 .

Production quantities should improve slightly for 2008 due to more efficient operations at Pogo Mine, commissioning of operations at Rock Creek Mine, and similar production from the other operating mines. The value of production should be less due to declining metal prices during the year. The value of production at Red Dog Mine, the most significant producer, will be about two-thirds to three-quarters of that for 2007. Production at Rock Creek Mine should be commissioned during the last quarter of 2008. Nixon Fork Mine will not operate. Commercial and recreational placer production will be about the same as in 2007 and no improvements are forecast in the industrial minerals sector. A 20 to 25 percent decrease in value of production should be experienced in 2008.

State revenue from the mining industry will drop again next year due to increasing costs of operation and to declining metal prices. That decrease is expected to be in the range of 25 to 30 percent of this year's total. The longer term future is expected to significantly improve state revenue as the industry matures and more of the current advanced exploration and developing projects are commissioned to producing mines. 
THIS PAGE INTENTIONALLY LEFT BLANK 
APPENDIX A

New claims staked in Alaska 2003-2007

\begin{tabular}{|c|c|c|c|c|c|c|c|c|c|c|c|}
\hline \multirow{2}{*}{$\begin{array}{c}\text { Quad } \\
\text { no. }\end{array}$} & \multirow{2}{*}{$\begin{array}{c}\text { Quadrangle } \\
\text { name }^{\mathrm{a}}\end{array}$} & \multicolumn{5}{|c|}{ New federal mining claims } & \multicolumn{5}{|c|}{ New state mining claims } \\
\hline & & 2003 & 2004 & 2005 & 2006 & 2007 & 2003 & 2004 & 2005 & 2006 & 2007 \\
\hline 18 & De Long Mountains & 0 & 0 & 0 & 0 & 0 & 0 & 0 & 0 & 0 & 0 \\
\hline 23 & Phillip Smith Mountains & 0 & 0 & 0 & 0 & 0 & 0 & 0 & 0 & 0 & 0 \\
\hline 26 & Noatak & 0 & 0 & 0 & 0 & 0 & 0 & 0 & 0 & 0 & 0 \\
\hline 27 & Baird Mountains & 0 & 0 & 0 & 0 & 0 & 0 & 60 & 20 & 260 & 4 \\
\hline 28 & Ambler River & 0 & 0 & 0 & 0 & 0 & 0 & 0 & 313 & 15 & 57 \\
\hline 29 & Survey Pass & 0 & 0 & 0 & 0 & 0 & 0 & 0 & 68 & 68 & 44 \\
\hline 30 & Wiseman & 45 & 16 & 14 & 250 & 134 & 54 & 0 & 13 & 0 & 4 \\
\hline 31 & Chandalar & 26 & 16 & 25 & 30 & 0 & 90 & 24 & 13 & 68 & 173 \\
\hline 36 & Selawik & 0 & 0 & 0 & 0 & 0 & 0 & 0 & 0 & 0 & 0 \\
\hline 38 & Hughes & 0 & 0 & 0 & 0 & 0 & 0 & 3 & 0 & 0 & 20 \\
\hline 39 & Bettles & 15 & 0 & 12 & 7 & 0 & 0 & 0 & 0 & 0 & 0 \\
\hline 43 & Teller & 0 & 0 & 0 & 0 & 0 & 2 & 0 & 36 & 80 & 111 \\
\hline 44 & Bendeleben & 0 & 0 & 0 & 0 & 0 & 53 & 194 & 55 & 405 & 632 \\
\hline 45 & Candle & 0 & 0 & 0 & 0 & 0 & 11 & 172 & 148 & 178 & 8 \\
\hline 47 & Melozitna & 0 & 0 & 0 & 0 & 0 & 0 & 0 & 0 & 28 & 0 \\
\hline 48 & Tanana & 1 & 0 & 0 & 0 & 0 & 32 & 53 & 45 & 46 & 52 \\
\hline 49 & Livengood & 0 & 0 & 0 & 0 & 0 & 111 & 117 & 89 & 125 & 41 \\
\hline 50 & Circle & 0 & 0 & 0 & 0 & 0 & 180 & 99 & 126 & 147 & 101 \\
\hline 51 & Charley River & 0 & 0 & 0 & 0 & 0 & 0 & 0 & 0 & 2 & 2 \\
\hline 52 & Nome & 0 & 0 & 0 & 0 & 0 & 13 & 9 & 7 & 57 & 31 \\
\hline 53 & Solomon & 0 & 0 & 0 & 0 & 9 & 6 & 3 & 48 & 56 & 25 \\
\hline 55 & Nulato & 0 & 0 & 0 & 0 & 0 & 40 & 0 & 69 & 0 & 0 \\
\hline 56 & Ruby & 0 & 0 & 0 & 0 & 0 & 1 & 9 & 0 & 9 & 15 \\
\hline 58 & Fairbanks & 0 & 0 & 0 & 0 & 0 & 114 & 102 & 70 & 96 & 61 \\
\hline 59 & Big Delta & 0 & 0 & 0 & 0 & 0 & 478 & 631 & 988 & 2,218 & 153 \\
\hline 60 & Eagle & 0 & 0 & 0 & 0 & 0 & 78 & 113 & 230 & 257 & 589 \\
\hline 64 & Ophir & 0 & 0 & 0 & 0 & 0 & 14 & 42 & 1 & 0 & 61 \\
\hline 65 & Medfra & 0 & 0 & 0 & 0 & 0 & 6 & 0 & 0 & 12 & 33 \\
\hline 67 & Healy & 0 & 0 & 0 & 0 & 0 & 19 & 111 & 149 & 47 & 271 \\
\hline 68 & Mt. Hayes & 21 & 24 & 253 & 0 & 4 & 471 & 156 & 84 & 429 & 127 \\
\hline 69 & Tanacross & 0 & 0 & 0 & 0 & 0 & 20 & 33 & 0 & 34 & 410 \\
\hline 73 & Iditarod & 0 & 0 & 0 & 0 & 0 & 13 & 213 & 1 & 589 & 302 \\
\hline 74 & McGrath & 0 & 0 & 0 & 0 & 0 & 0 & 142 & 0 & 139 & 72 \\
\hline 75 & Talkeetna & 0 & 0 & 0 & 0 & 0 & 171 & 166 & 178 & 383 & 62 \\
\hline 76 & Talkeetna Mountains & 0 & 0 & 0 & 0 & 0 & 0 & 33 & 234 & 65 & 72 \\
\hline 77 & Gulkana & 8 & 0 & 0 & 0 & 0 & 0 & 0 & 0 & 103 & 85 \\
\hline 78 & Nabesna & 0 & 0 & 0 & 0 & 0 & 0 & 0 & 1 & 0 & 56 \\
\hline 81 & Russian Mission & 0 & 0 & 0 & 0 & 0 & 0 & 0 & 0 & 160 & 0 \\
\hline 82 & Sleetmute & 0 & 0 & 0 & 0 & 0 & 28 & 0 & 6 & 25 & 753 \\
\hline 83 & Lime Hills & 0 & 0 & 0 & 0 & 0 & 5 & 32 & 271 & 122 & 281 \\
\hline 84 & Tyonek & 0 & 0 & 0 & 0 & 0 & 57 & 597 & 113 & 125 & 81 \\
\hline 85 & Anchorage & 0 & 0 & 0 & 0 & 0 & 104 & 75 & 80 & 72 & 66 \\
\hline 86 & Valdez & 0 & 0 & 0 & 0 & 0 & 1 & 3 & 1 & 48 & 1 \\
\hline 91 & Bethel & 0 & 0 & 0 & 0 & 0 & 0 & 0 & 8 & 154 & 516 \\
\hline 92 & Taylor Mountains & 0 & 0 & 0 & 0 & 0 & 2 & 87 & 26 & 55 & 10 \\
\hline 93 & Lake Clark & 0 & 0 & 0 & 0 & 0 & 501 & 267 & 866 & 87 & 831 \\
\hline 95 & Seward & 21 & 10 & 18 & 13 & 29 & 6 & 18 & 7 & 12 & 18 \\
\hline 96 & Cordova & 0 & 0 & 0 & 0 & 0 & 0 & 0 & 0 & 0 & 0 \\
\hline 101 & Goodnews Bay & 0 & 0 & 0 & 0 & 0 & 0 & 12 & 0 & 0 & 0 \\
\hline 102 & Dillingham & 0 & 0 & 0 & 0 & 0 & 34 & 5 & 147 & 0 & 99 \\
\hline 103 & Iliamna & 0 & 0 & 0 & 0 & 0 & 720 & 944 & 318 & 26 & 171 \\
\hline 104 & Seldovia & 0 & 0 & 0 & 0 & 0 & 0 & 3 & 0 & 0 & 0 \\
\hline 105 & Blying Sound & 0 & 0 & 0 & 0 & 0 & 0 & 0 & 0 & 0 & 4 \\
\hline 109 & Skagway & 0 & 0 & 0 & 0 & 0 & 1 & 0 & 4 & 20 & 100 \\
\hline
\end{tabular}




\begin{tabular}{|c|c|c|c|c|c|c|c|c|c|c|c|}
\hline \multirow{2}{*}{$\begin{array}{l}\text { Quad } \\
\text { no. }\end{array}$} & \multirow{2}{*}{$\begin{array}{c}\text { Quadrangle } \\
\text { name }^{\mathrm{a}}\end{array}$} & \multicolumn{5}{|c|}{ New federal mining claims } & \multicolumn{5}{|c|}{ New state mining claims } \\
\hline & & 2003 & 2004 & 2005 & 2006 & 2007 & 2003 & 2004 & 2005 & 2006 & 2007 \\
\hline 112 & Juneau & 68 & 0 & 0 & 1 & 67 & 6 & 6 & 2 & 7 & 0 \\
\hline 114 & Sitka & 9 & 0 & 0 & 0 & 9 & 0 & 0 & 0 & 0 & 1 \\
\hline 117 & Petersburg & 39 & 0 & 1 & 54 & 23 & 3 & 0 & 0 & 0 & 0 \\
\hline 118 & Bradfield Canal & 0 & 0 & 0 & 0 & 0 & 0 & 0 & 0 & 0 & 0 \\
\hline 119 & Craig & 380 & 0 & 83 & 94 & 365 & 3 & 0 & 2 & 0 & 0 \\
\hline 120 & Ketchikan & 0 & 0 & 0 & 0 & 0 & 0 & 2 & 0 & 0 & 0 \\
\hline 121 & Dixon Entrance & 0 & 0 & 13 & 8 & 293 & 0 & 0 & 0 & 0 & 0 \\
\hline 122 & Prince Rupert & 30 & 0 & 0 & 0 & 0 & 0 & 0 & 0 & 0 & 0 \\
\hline 128 & Bristol Bay & 0 & 0 & 0 & 0 & 0 & 0 & 0 & 10 & 0 & 0 \\
\hline 129 & Ugashik & 0 & 0 & 0 & 0 & 0 & 0 & 0 & 0 & 16 & 0 \\
\hline 130 & Karluk & 0 & 0 & 0 & 0 & 0 & 0 & 18 & 0 & 0 & 0 \\
\hline 131 & Kodiak & 0 & 0 & 0 & 0 & 0 & 0 & 0 & 1 & 0 & 0 \\
\hline 133 & Chignik & 0 & 0 & 0 & 0 & 0 & 0 & 41 & 6 & 0 & 0 \\
\hline 135 & Trinity Islands & 0 & 0 & 0 & 0 & 0 & 11 & 8 & 383 & 13 & 1 \\
\hline \multirow[t]{2}{*}{136} & Kaguyak & 0 & 0 & 0 & 0 & 0 & 0 & 0 & 71 & 0 & 0 \\
\hline & TOTALS & 663 & 66 & 419 & 457 & 933 & 3,459 & 4,603 & 5,308 & 6,858 & 6,607 \\
\hline
\end{tabular}

Source: Data provided by Alaska Department of Natural Resources Land Records Information Section and U.S. Bureau of Land Management.

a'Unlisted quadrangles did not have any staked mining claims between 2003 and 2007.

*Eight federal claims extend over two quadrangles. 


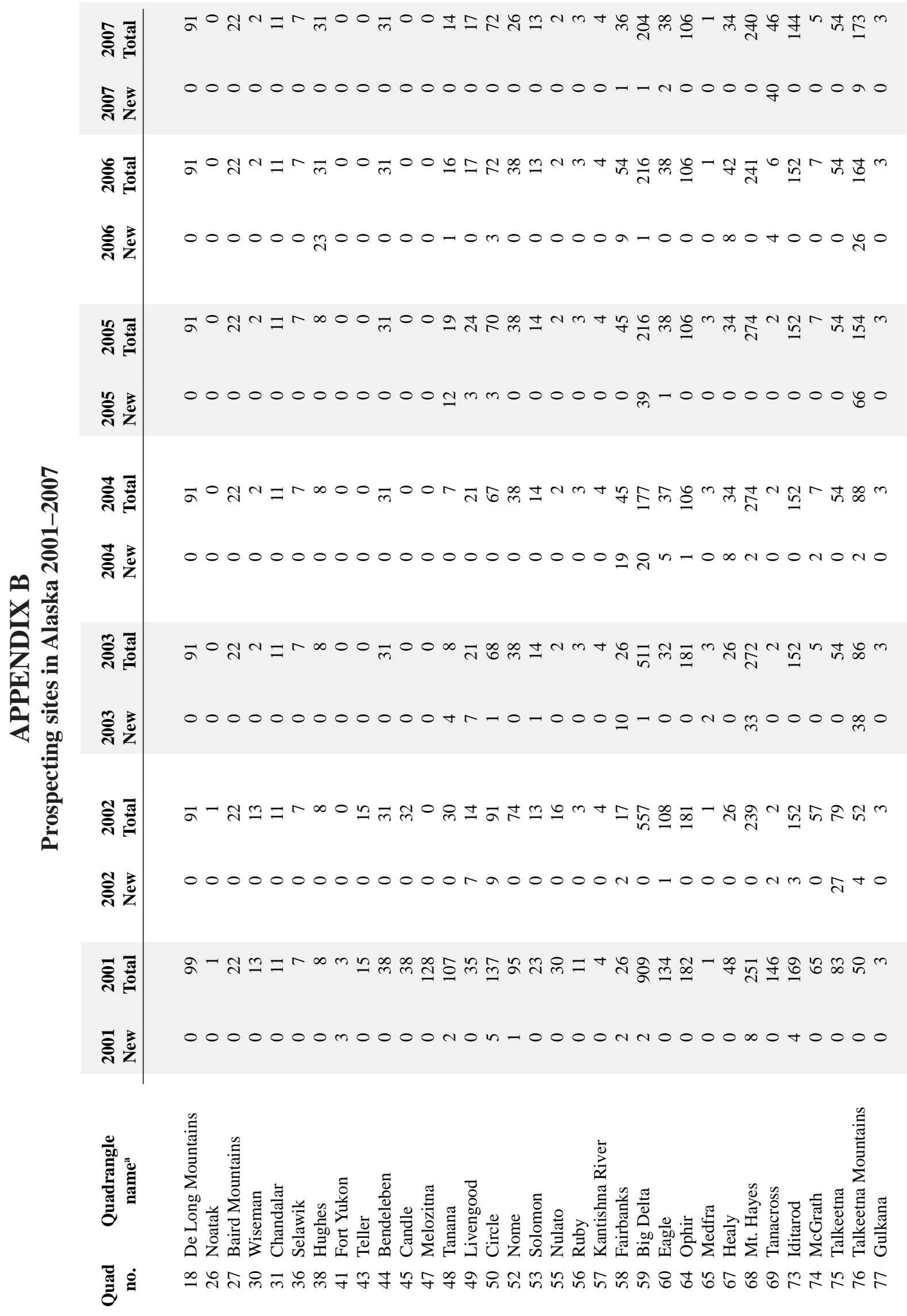




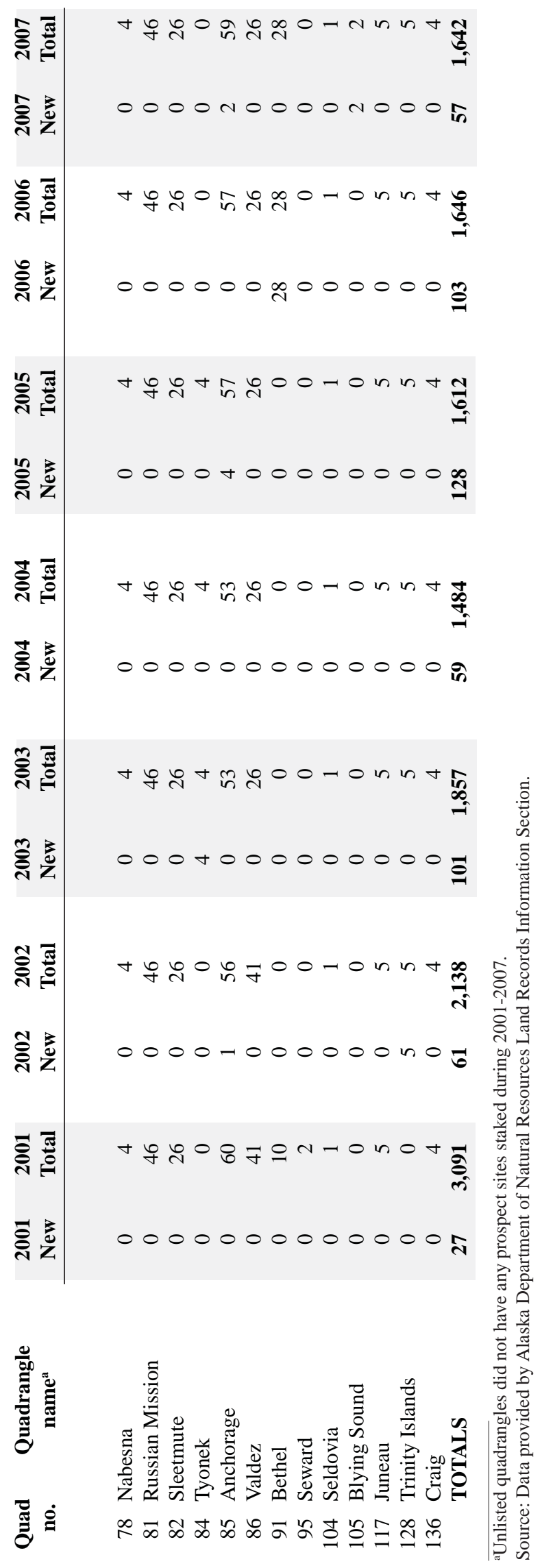




\section{APPENDIX C}

\section{Selected significant mineral deposits and mineral districts in Alaska ${ }^{\mathrm{a}}$}

The alphabetized list of mineral deposits and mineral districts is keyed to the list of explanatory paragraphs that follow. For example, The Lik deposit in the alphabetized list is "Lik, 1, (fig. C-1)." This says that the location of Lik is shown as number 1 in figure $\mathrm{C}-1$.

Alaska-Juneau, 100, (fig. C-3).

Anderson Mountain, 54, (fig. C-1).

Aniak district, 84, (fig C-3).

Apex-El Nido, 104, (fig. C-3).

Apollo-Sitka mines, 86, (fig. C-3).

Arctic, 9, (fig. C-1).

Avan Hills, 12, (fig. C-3).

Baultoff, 75, (fig. C-2).

Bear Mountain, 21, (fig. C-2).

Big Creek/Ladue, 58, (fig. C-1)

Big Hurrah, 32, (fig. C-3).

Binocular and other prospects, 72, (fig. C-1).

Bohemia Basin, 103, (fig. C-3).

Bokan Mountain, 122, (fig. C-3).

Bonanza Creek, 45, (fig. C-2).

Bond Creek, 73, (fig. C-2).

Bonnifield district massive sulfide deposits, 54, (fig. C-1).

Bornite, 8, (fig. C-1).

Brady Glacier, 98, (fig. C-3).

BT, 54, (fig. C-1).

Buck Creek, 23, (fig. C-2).

Calder Mine, 133, (fig C-2).

Canwell and Nikolai Complex, 140 (fig. C-3)

Cape Creek, 22, (fig. C-2).

Carl Creek, 74, (fig. C-2).

Casca VABM, 53, (fig. C-1).

Castle Island, 111, (fig. C-1).

Chandalar mining district, 17 , (fig. C-3).

Chichagof, 101, (fig. C-3).

Chistochina, 68, (figs. C-2, C-3).

Circle mining district, 52, (fig. C-3).

Claim Point, 82, (fig. C-3).

Coal Creek, 63, (fig. C-2).

Copper City, 119, (fig. C-1).

Cornwallis Peninsula, 110, (fig. C-1).

Council mining district, 33, (fig. C-3).

Delta massive sulfide belt, 55, (fig. C-1).

Denali prospect, 67, (fig. C-1).

Dolphin, 49e, (fig. C-3).

Donlin Creek, 137, (fig. C-3).

Drenchwater, 3, (fig. C-1).

Dry Creek, 54, (fig. C-1).

Duke Island, 141 (fig. C-3)

Eagle Creek, 34, (fig. C-3).

Ear Mountain, 25, (fig. C-2).

Ellamar, 78, (fig. C-1).

Ernie Lake (Ann Creek), 15, (fig. C-1).

Esotuk Glacier, 20, (fig. C-2).

Fairbanks mining district, 49, (fig. C-3).

Fairhaven/Inmachuk district, 39,

(fig. C-3).

Fort Knox, 49a, (fig. C-3).

Fortymile mining district, 60, (fig. C-3).

Frost, 7a, (fig. C-1).

Funter Bay mining district, 99, (fig. C-3).

Galena Creek, 21a, (fig. C-1).

Gil Claims, 49f, (fig. C-3).
Ginny Creek, 4, (fig. C-1).

Golden Zone mine, 64, (figs. C-1, C-3).

Goodnews Bay, 85, (fig. C-3).

Grant Mine, 49c, (fig. C-3).

Greens Creek, 105, (fig. C-1).

Groundhog Basin, 112, (fig. C-1).

Haines Barite/Palmer, 95, (fig. C-1).

Hannum, 27, (fig. C-1).

Hirst Chichagof, 101, (fig. C-3).

Horsfeld, 76, (fig. C-2).

Hot Springs mining district, 47,

(figs. C-2, C-3).

Hyder mining district, 117, (figs. C-1, C-2).

Iditarod district, 43, (fig. C-3).

Illinois Creek, 132, (figs. C-1, C-3).

Independence, 79, (fig. C-3).

Independence Creek, 28, (fig. C-1).

Inmachuk River, 39, (fig. C-3).

Innoko-Tolstoi mining district, 44,

(fig. C-3).

Ivanof, 88, (fig. C-2).

Jimmy Lake, 94, (fig. C-1).

Johnson River, 125, (fig. C-3).

Jualin, 128, (fig. C-3).

Jumbo, 118, (fig. C-1).

Kaiyah, 138, (fig. C-3).

Kantishna mining district, 61, (fig. C-3).

Kasaan Peninsula, 114, (fig. C-1).

Kasna Creek, 92, (fig. C-1).

Kemuk Mountain, 123, (fig. C-3).

Kennecott deposits, 71, (fig. C-1).

Kensington, 127, (fig. C-3).

Kivliktort Mountain, 5a, (fig. C-1).

Klery Creek, 14, (fig. C-3).

Klukwan, 96, (fig. C-3).

Kougarok Mountain, 26, (fig. C-2).

Koyukuk-Hughes mining district, 42 , (fig. C-3).

Koyukuk-Nolan mining district, 16 , (fig. C-3).

Latouche, Beatson, 80, (fig. C-1).

Liberty Bell, 54, (fig. C-1).

Lik, 1, (fig. C-1).

Livengood-Tolovana mining district, 48 , (fig. C-3).

Lost River, 24, (fig. C-2).

Lucky Shot, 79, (fig. C-3).

McLeod, 124, (fig. C-2).

Mertie Lode, 99, (fig. C-3).

Midas mine, 77, (fig. C-1).

Mike deposit, 90, (fig. C-2).

Mirror Harbor, 102, (fig. C-3).

Misheguk Mountain, 13, (fig. C-3).

Mosquito, Peternie, 56, (fig. C-2).

Mt. Prindle, 50, (fig. C-3).

Nabesna mine, 69, (fig. C-3).

Niblack, 121, (fig. C-1).

Nim prospect, 65, (fig. C-1).

Nimiuktuk River, 126, (fig. C-1).
Nixon Fork, 135, (fig. C-3).

Nome mining district, 30 , (fig. C-3).

Nunatak, 97, (fig. C-2)

Omalik, 35, (fig. C-1).

Omar, 7, (fig. C-1).

Orange Hill, 73, (fig. C-2).

Pebble Copper, 129, (fig. C-1).

Placer River, 38, (fig. C-2).

Pleasant Creek, 53, (fig. C-1).

Pogo, 130, (fig. C-3).

Poovookpuk Mountain, 40, (fig. C-2).

Porcupine Lake, 18, (fig. C-2).

Purcell Mountain, 41, (fig. C-2).

Pyramid, 87, (fig. C-2).

Quartz Creek, 37, (fig. C-1).

Quartz Hill, 120, (fig. C-2).

Red Bluff Bay, 109, (fig. C-3).

Red Devil, 83, (fig. C-3).

Red Dog, 2, (fig. C-1).

Red Mountain, 82, (fig. C-3).

Rex deposit, 91, (fig. C-2).

Rock Creek, 31, (fig. C-3).

Rua Cove, 81, (fig. C-1).

Ruby mining district, 46, (fig. C-3).

Ryan Lode, 49b, (fig. C-3).

Salt Chuck, 115, (fig. C-3).

Sheep Creek, 54, (fig. C-1).

Shotgun Hills, 131, (fig. C-3).

Shulin Lake, 139 (fig. C-3)

Sinuk River region, 29, (fig. C-1).

Slate Creek, 59, (fig. C-3).

Sleitat Mountain, 93, (fig. C-2).

Smucker, 11, (fig. C-1).

Snettisham, 107, (fig. C-3).

Snipe Bay, 113, (fig. C-3).

Solomon mining district, 33, (fig. C-3).

Spirit Mountain, 70, (fig. C-3).

Stampede mine, 62, (fig. C-3).

Story Creek, 5, (fig. C-1).

Sumdum, 106, (fig. C-1).

Sun, 10, (fig. C-1).

Taurus, 57, (fig. C-2).

Three Castle Mountain, 53, (fig. C-1).

Tracy Arm, 108, (fig. C-1).

True North, 49d, (fig. C-3).

Twin Mountain, 51, (fig. C-2).

Union Bay, 116, (fig. C-3).

Valdez Creek district, 66, (fig. C-3).

Vinasale Mountain, 134, (fig. C-3).

Virginia Creek, 54, (fig. C-1).

Von Frank Mountain, 136, (fig. C-3).

War Baby, 79, (fig. C-3).

Weasel Mountain, Bee Creek, 89,

(fig. C-2).

Whoopee Creek, 6, (fig. C-1).

Willow Creek, 79, (fig. C-3).

Wind River, 19, (fig. C-1).

Windy Creek, 36, (fig. C-2).

Zackly, 67a, (fig. C-1).

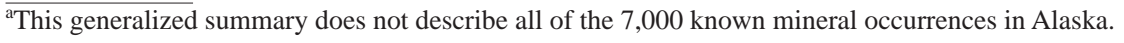

NOTE: In cooperation with DGGS and the Russian Academy of Sciences, the USGS published Open-File Report 93-339 (Nokleberg and others, 1993), Metallogenesis of mainland Alaska and the Russian northeast, which describes 273 lode deposits and 43 significant placer districts in Alaska. 


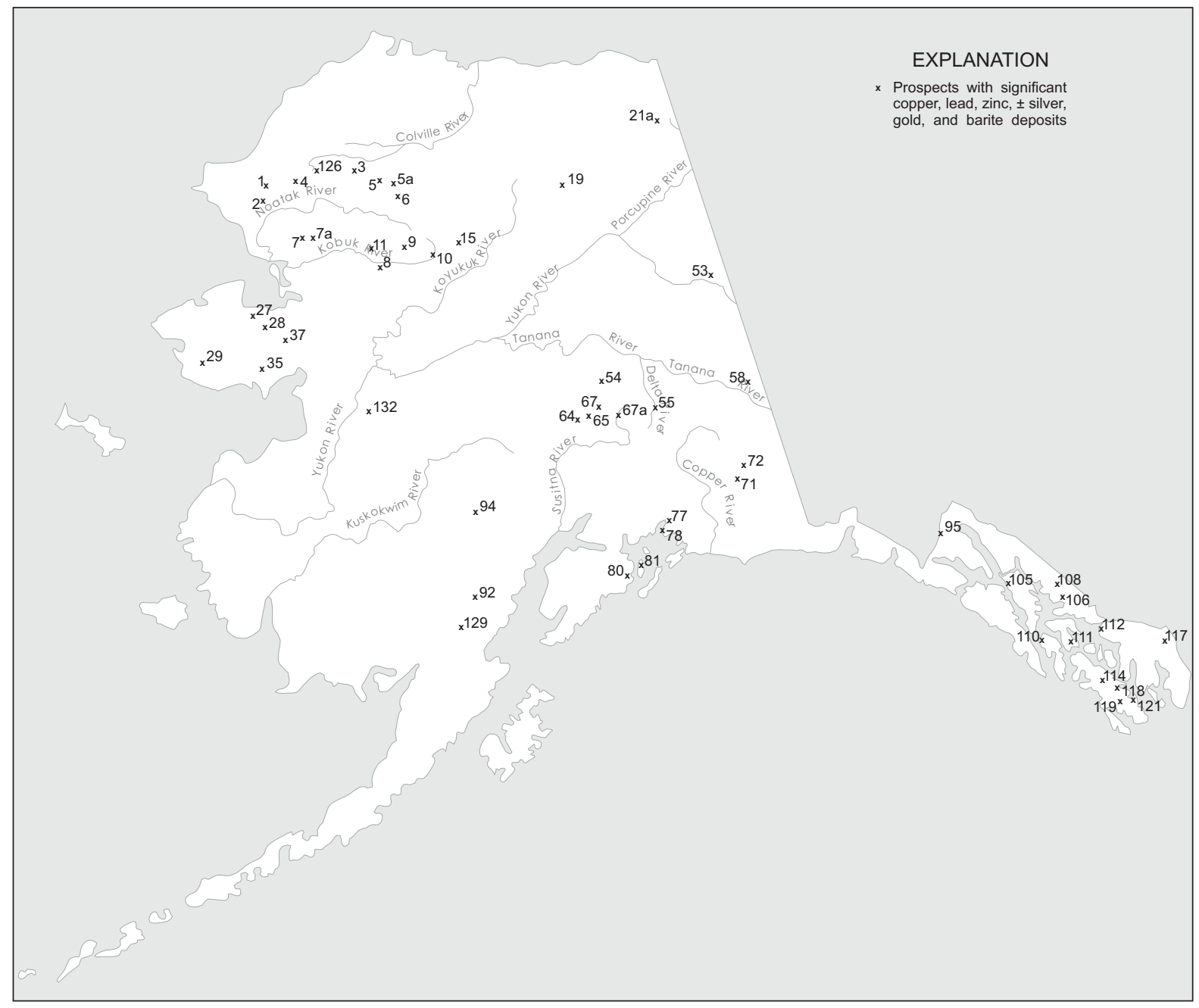

Figure C-1. Significant copper, lead, zinc with credits of silver, gold, and barite deposits in Alaska, 2007.

Map no.

1 Lik-Major stratabound massive sulfide ( $\mathrm{Zn}-\mathrm{Pb}-\mathrm{Ag}-$ Ba) deposit in black shale and chert. Proven reserve (Lik) estimate of 24 million tons of $9 \% \mathrm{Zn}, 3.1 \% \mathrm{~Pb}$, and $1.4 \mathrm{oz} /$ ton Ag (fig. C-1).

2 Red Dog-At least five major stratabound massive sulfide deposits hosted in Pennsylvanian or Mississippian shale; similar to locality 1 . Mining from 1989 to 2006 produced 7.7 million tons of Zn, 1.35 million tons of $\mathrm{Pb}$, and 74.4 million oz Ag. Deposits, with announced reserves from 2000, include: (a) The Main deposit at Red Dog contains 46.2 million tons of proven ore grading $19.2 \% \mathrm{Zn}, 5.2 \% \mathrm{~Pb}$, with 2.92 oz/ton Ag. (b) The Aqqaluk deposit contains probable, indicated, and inferred reserves of 73.0 million tons grading $15.2 \% \mathrm{Zn}, 4.03 \% \mathrm{~Pb}$, and $2.17 \mathrm{oz} / \mathrm{ton} \mathrm{Ag}$. (c) The Qanaiyaq (formerly named Hilltop) deposit with an indicated reserve is 10.6 million tons grading $17.8 \% \mathrm{Zn}, 5.5 \% \mathrm{~Pb}$, and $3.41 \mathrm{oz} /$ ton Ag. (d) Inferred resource in the Paalaaq deposit is 14.3 million tons of $15.0 \% \mathrm{Zn}, 4.0 \% \mathrm{~Pb}$, and $2.63 \mathrm{oz} /$ ton Ag. (e) Anarraq deposit discovered in 1999 has an inferred reserve of 19.0 million tons of $15.8 \% \mathrm{Zn}, 4.8 \% \mathrm{~Pb}$, and 2.07 oz/ton Ag (fig. C-1).

3 Drenchwater-Mississippian and Pennsylvanian shales and cherts contain three stratabound base metal occurrences spatially related to acid volcanics. The lowest unit, a siliceous mudstone, contains a $2 \mathrm{ft}$ layer with up to $23 \% \mathrm{Zn}$. An overlying gray chert contains up to $11 \% \mathrm{Zn}$ and up to $5 \% \mathrm{~Pb}$ with some $\mathrm{Ag}$ in fracture fillings. At the top of the overlying tuffaceous layer, Ag-bearing $\mathrm{Zn}$ and $\mathrm{Pb}$ mineralization outcrops discontinuously for at least $6,500 \mathrm{ft}$, and contains up to $26 \% \mathrm{Zn}$ and $51 \% \mathrm{~Pb}$ in grab samples (fig. C-1).

4 Ginny Creek-Epigenetic, disseminated $\mathrm{Zn}-\mathrm{Pb}-\mathrm{Ag}$ deposits with barite in sandstone and shale of Late Devonian through Early Mississippian Noatak Sandstone . Random grab samples of float contain $0.3 \%$ to $3.0 \% \mathrm{Zn}$ and highly variable amounts of $\mathrm{Pb}$ and Ag (fig. C-1).

5 Story Creek-Epigenetic replacement deposits of $\mathrm{Zn}-\mathrm{Pb}-\mathrm{Ag}-\mathrm{Cu}-\mathrm{Au}$ hosted in brecciated zones in Devonian Kanayut Conglomerate or Lower Mississippian Kayak Shale. Grab samples of high- 


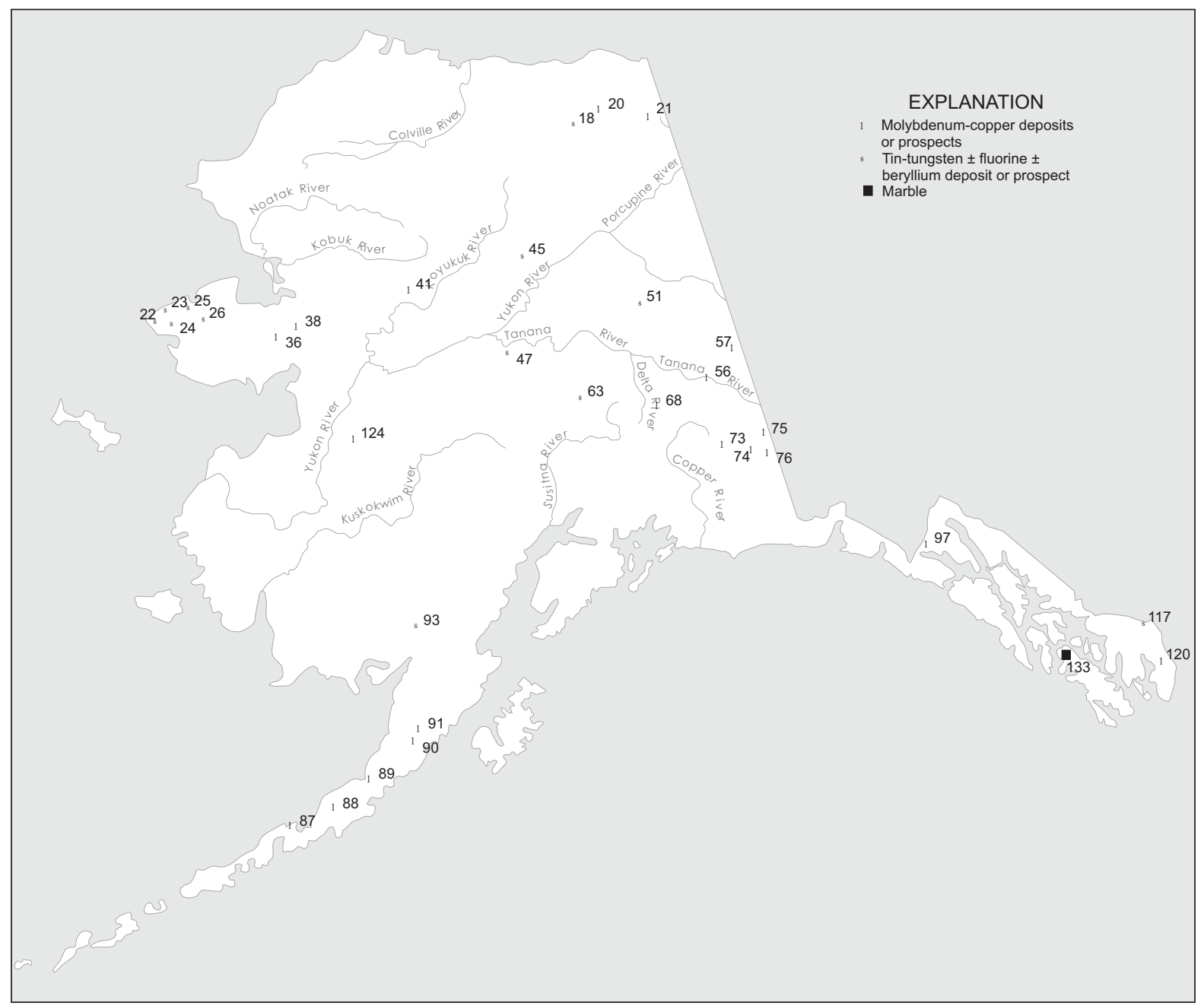

Figure C-2. Significant molybdenum-copper and tin-tungsten with credits of fluorite and beryllium deposits in Alaska, 2007.

grade material contain up to $0.43 \% \mathrm{Cu}, 34 \% \mathrm{~Pb}$, 28.8\% Zn, 0.04 oz/ton Au, and 30 oz/ton Ag (fig. C-1).

5a Kivliktort Mountain-Mineralized float is widespread on the north flanks of the mountain, apparently spatially related to the contact between shales at the base of the hills and coarse-grained siliceous clastic rocks on the upper slopes. Rock samples containing up to $30 \% \mathrm{Zn}$ have been reported (fig. C-1).

6 Whoopee Creek-Epigenetic replacement deposits of $\mathrm{Zn}-\mathrm{Pb}-\mathrm{Cu}-\mathrm{Ag}-\mathrm{Au}-\mathrm{Cd}$ in breccia zones in Devonian Kanayut Conglomerate or Lower Mississippian Kayak Shale. Random grab samples of mineralized material contain $0.24 \% \mathrm{Cu}, 0.37 \% \mathrm{Cd}, 46 \% \mathrm{Zn}, 44 \% \mathrm{~Pb}, 0.14$ oz/ton Au, and $14.8 \mathrm{oz} /$ ton Ag (fig. C-1).

7 Omar-Epigenetic replacement deposits of Paleozoic age; include bedded barite occurrences. Grab samples contain $15.3 \% \mathrm{Cu}, 0.15 \% \mathrm{~Pb}, 0.95 \% \mathrm{Zn}, 0.05 \% \mathrm{Co}$, and $0.3 \mathrm{oz} / \mathrm{ton} \mathrm{Ag}$. BLM estimates 35 million tons of $4 \% \mathrm{Cu}$ (fig. C-1).

7a Frost-Possible 9 million tons of barite in pods, lenses, and wavy-banded quartz-calcite-barite veins.
Chalcopyrite and galena occur in veins which cross cut Paleozoic limestone and dolomite for a minimum distance of $1 \mathrm{mi}$. Selected samples contain up to 13.2\% Zn (fig. C-1).

8 Bornite-Major stratabound $\mathrm{Cu}-\mathrm{Zn}$ deposit in brecciated carbonate rock of Devonian age; 5.0 million ton orebody contains $4.0 \% \mathrm{Cu}$ and accessory $\mathrm{Zn}$ and Co. Larger reserve estimate of 40 million tons of about $2 \% \mathrm{Cu}$ and undisclosed amount of $\mathrm{Zn}$ and Co. At grade of $1.2 \% \mathrm{Cu}$, reserves are 100 million tons (fig. C-1).

9 Arctic-Major volcanogenic ( $\mathrm{Cu}-\mathrm{Zn})$ massive sulfide deposit hosted in sequence of metarhyolite, metatuff, and graphitic schist of Devonian age; indicated reserves of 40 million tons grade $4.0 \% \mathrm{Cu}, 5.5 \% \mathrm{Zn}$, $0.8 \% \mathrm{~Pb}, 1.6 \mathrm{oz} / \mathrm{ton} \mathrm{Ag}$, and $0.02 \mathrm{oz} / \mathrm{ton} \mathrm{Au}$ (fig. C-1).

10 Sun-Major ( $\mathrm{Cu}-\mathrm{Pb}-\mathrm{Zn}$-Ag) massive sulfide deposit in sequence of middle Paleozoic metarhyolite and metabasalt. Average grades are 1 to $4 \% \mathrm{~Pb}, 6$ to $12 \%$ Zn, 0.5 to $7 \% \mathrm{Cu}, 3$ to $11 \mathrm{oz} /$ ton Ag (fig. C-1).

11 Smucker-Middle Paleozoic volcanogenic massive sulfide deposit; 3,000 ft long and up to $190 \mathrm{ft}$ wide; 


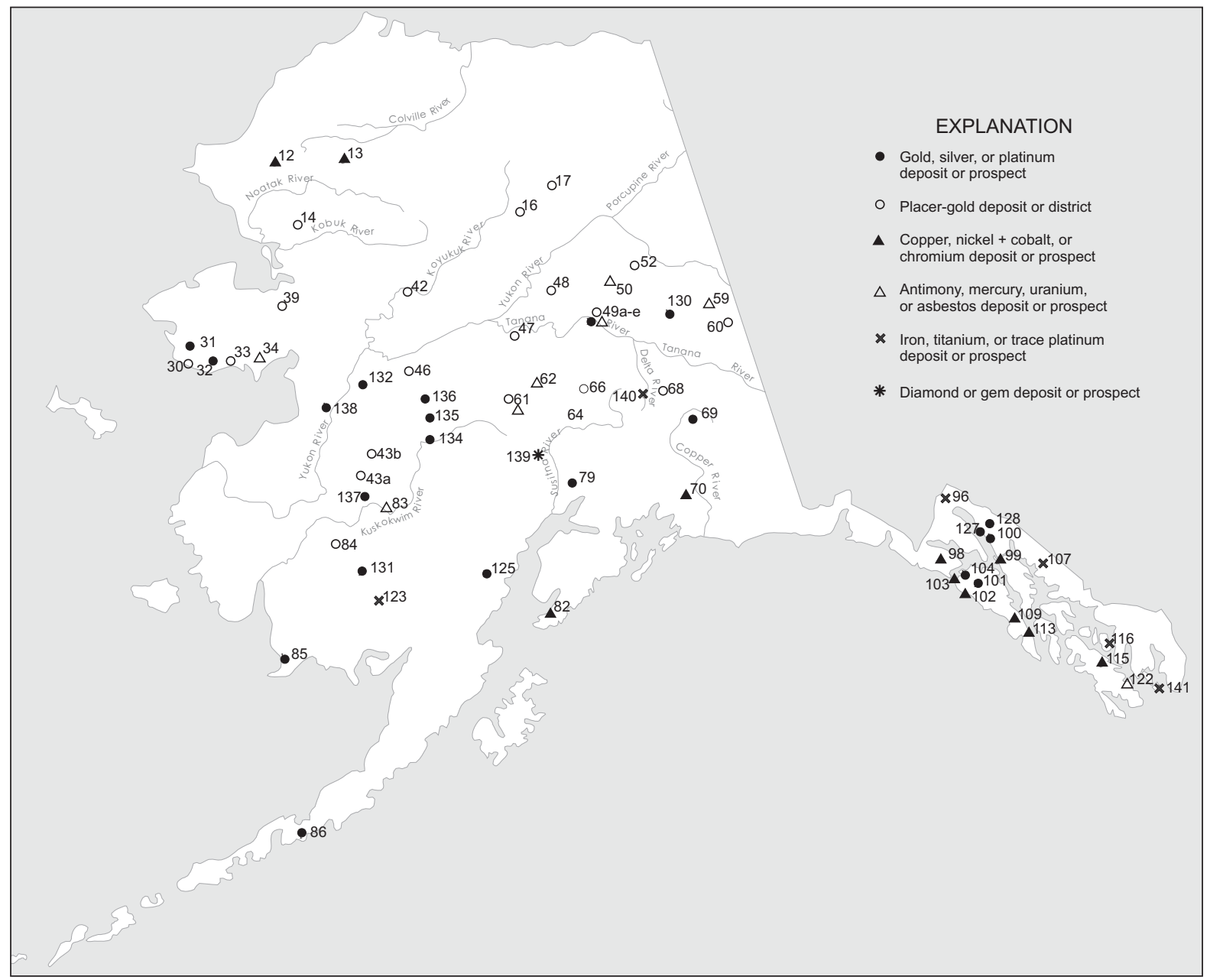

Figure C-3. Significant gold, silver, platinum, and strategic mineral deposits in Alaska, 2007.

contains significant tonnage of $\mathrm{Cu}-\mathrm{Pb}-\mathrm{Zn}$ ore that grades $1.5 \% \mathrm{~Pb}, 5$ to $10 \% \mathrm{Zn}, 3$ to $10 \mathrm{oz} /$ ton $\mathrm{Ag}$, with minor Au (fig. C-1).

12 Avan Hills-Disseminated chromite in layered ultramafic rocks; grab samples contain up to $4.3 \% \mathrm{Cr}$ with $0.015 \mathrm{oz} /$ ton PGM (fig. C-3).

13 Misheguk Mountain-Chromite occurrences similar to those in Avan Hills (fig. C-3).

14 Klery Creek-Lode and placer Au deposits worked intermittently from 1909 through 1930s. Total production through 1931, mostly from placer deposits, estimated at 31,320 oz Au (fig. C-3).

15 Ernie Lake (Ann Creek) - Stratabound massive sulfide occurrence in metarhyolite, metatuff, and marble.

Gossan zones strongly anomalous in $\mathrm{Cu}-\mathrm{Pb}-\mathrm{Zn}$ and Ag (fig. C-1).

16 Koyukuk mining district-Major placer Au district; from 1893 to 2006 produced an estimated 347,661 oz Au. Gold placers in Nolan Creek mined on surface and underground, both sources of large gold nuggets. Significant deep placer reserves remain (fig. C-3).
17 Chandalar mining district-Major Au-producing district; substantial production in excess of $66,287 \mathrm{oz}$ Au through 2006 from lode and placer sources; lode Au found in crosscutting quartz veins that intrude schist and greenstone. Active development of placer deposits and lodes in progress. Inferred lode reserves estimated to be 45,000 tons with grade of $2 \mathrm{oz} /$ ton $\mathrm{Au}$ (fig. C-3).

18 Porcupine Lake-Stratiform fluorite occurrences and argentiferous enargite, tetrahedrite associated with felsic volcanic rocks of late Paleozoic age. Reported grades of up to $30 \%$ fluorite $(\mathrm{CaF} 2)$ reported, with grab samples of $4.8 \% \mathrm{Cu}$ (fig. C-2).

19 Wind River-Stratabound $\mathrm{Pb}-\mathrm{Zn}$ massive sulfide prospects; reported grades of up to $5 \% \mathrm{~Pb}$ (fig. C-1).

20 Esotuk Glacier-Disseminated Mo-Sn-W-Pb-Zn mineralization in skarns associated with Devonian(?) schistose quartz monzonite. Grab samples contain up to $0.08 \%$ Sn and $0.15 \% \mathrm{~W}$ (fig. C-2).

21 Bear Mountain-Major stockwork Mo-W-Sn occurrence in intrusive breccia. Rock samples containing up to $0.8 \%$ Mo and $0.6 \% \mathrm{~W}$ occur within a 35-acre area where soil samples average more than 
$0.2 \% \mathrm{MoS} 2$, and an adjacent 25-acre area where rubble contains wolframite has soils averaging greater than $0.12 \%$ WO3. Rubble crop in this area indicates a Tertiary porphyry system as the source of the Mo and W (fig. C-2).

21a Galena Creek-Steeply dipping veins contain up to $21 \% \mathrm{Cu}, 3.5 \% \mathrm{Zn}$, and $1.3 \% \mathrm{~Pb}$ with $5.5 \mathrm{oz} /$ ton $\mathrm{Ag}$ on the east side of the creek, and on the ridge west of the creek a large area of disseminated mineralization and veinlets contains predominantly Zn (fig. C-1).

22 Cape Creek-Major placer Sn producer. More than 500 tons Sn produced from 1935 to 1941; from 1979 to 1990, produced 1,040 tons Sn. Derived from Cape Mountain in contact zone of Cretaceous granite and limestone (fig. C-2).

23 Buck Creek-Major placer Sn producer. More than 1,100 tons Sn produced from 1902 to 1953 (fig. C-2).

24 Lost River-Major Sn, fluorite, W, and Be deposit associated with Cretaceous Sn granite system. More than 350 tons Sn produced from skarn and greisen lode sources. Measured reserves amount to 24.6 million tons that grade $0.15 \% \mathrm{Sn}, 16.3 \% \mathrm{CaF} 2$, and $0.03 \%$ WO3, based on $45,000 \mathrm{ft}$ of diamond drilling (fig. C-2).

25 Ear Mountain-Placer Sn district and $\mathrm{Sn}-\mathrm{Cu}-\mathrm{Au}-$ $\mathrm{Ag}-\mathrm{Pb}-\mathrm{Zn}$ skarn mineralization of Cretaceous age. Area also anomalous in U (fig. C-2).

26 Kougarok Mountain-Sn deposit hosted in quartztourmaline-topaz greisen of Cretaceous age. Grades may average $0.5 \% \mathrm{Sn}$ and $0.01 \%$ Ta and $\mathrm{Nb}$, but a high-grade resource of 150,000 tons grading $1 \%+\mathrm{Sn}$ was identified, with incrementally higher tonnage at lower grades (fig. C-2).

27 Hannum - Stratiform, carbonate-hosted Pb-Zn-Ag massive sulfide deposit of mid-Paleozoic age in heavily oxidized zone that ranges from 30 to $150 \mathrm{ft}$ thick. Mineralized zone reported to assay up to $10 \%$ $\mathrm{Pb}, 2.2 \% \mathrm{Zn}, 0.04 \mathrm{oz} /$ ton $\mathrm{Au}$, and $1.76 \mathrm{oz} /$ ton $\mathrm{Ag}$ (fig. C-1).

28 Independence Creek- $\mathrm{Pb}-\mathrm{Zn}$-Ag massive sulfide deposit; high-grade ore shipped in 1921 contained $30 \% \mathrm{~Pb}, 5 \% \mathrm{Zn}$, up to $150 \mathrm{oz} / \mathrm{ton} \mathrm{Ag}$. Mineralization restricted to shear zone in carbonates (fig. C-1).

29 Sinuk River region-Several $\mathrm{Pb}-\mathrm{Zn}-\mathrm{Ag}-\mathrm{Ba}-\mathrm{F}$ bearing massive sulfide deposits and layered $\mathrm{Fe}$ deposits in carbonate and metavolcanic rocks of Nome Group. Mineralized zones extend for over 8,000 ft along strike (fig. C-1).

30 Nome mining district-Major placer Au producer. Production from 1897-2006 in excess of 4,998,886 oz Au, all from placers. Past $\mathrm{Sb}$ and $\mathrm{W}$ production (fig. C-3).

31 Rock Creek-550,000 oz Au resource, with about 11.79 million tons grading $0.059 \mathrm{oz} /$ ton $\mathrm{Au}$ in vein swarms and stringers in an area 1,500 ft long, $500 \mathrm{ft}$ maximum width and $300 \mathrm{ft}$ deep (fig. C-3).

32 Big Hurrah-Epigenetic vein deposit in black slate and metasedimentary rocks of the Solomon schist. Deposit contains some W mineralization and has produced over 27,000 oz Au from nearly 50,000 tons milled ore. Proven, inferred, and indicated reserves total 104,000 tons that grade $0.61 \mathrm{oz} /$ ton $\mathrm{Au}, 0.55$ oz/ton Ag, and credits of WO3 (fig. C-3).

33 Solomon and Council mining districts-Major placer Au districts; produced over 1,046,522 oz through 2006. Three structurally controlled Au deposits in Bluff area-Daniels Creek, Saddle, and Koyana Creek-contain minimum inferred reserves of 6.5 million tons grading $0.1 \mathrm{oz} /$ ton $\mathrm{Au}$ (fig. C-3).

34a Eagle Creek - U prospect in Cretaceous Kachauik alkalic intrusive rocks. Highly anomalous U concentrations up to 1,000 ppm reported (fig. C-3).

34b Death Valley (Boulder Creek) - Sandstonetype U prospect with predominantly epigenetic mineralization. Over 11,000 feet of drilling defined a minimum reserve of 1 million pounds of $\mathrm{U}_{3} \mathrm{O}_{8}$ with average grade of $0.27 \% \mathrm{U}_{3} \mathrm{O}_{s}$ and 9.9 foot thickness within 200 feet of surface (fig. C-3).

35 Omalik-Vein-type $\mathrm{Pb}-\mathrm{Zn}$-Ag massive sulfide prospect in Paleozoic carbonate rocks; from 1881 to 1900, produced 400 tons of $\mathrm{Pb}-\mathrm{Zn}$ ore that averaged about $10 \% \mathrm{~Pb}$ and $40 \mathrm{oz} /$ ton Ag. Grades of oxidized $\mathrm{Zn}$ ore reported to be up to $34 \% \mathrm{Zn}$ (fig. C-1).

36 Windy Creek-Disseminated $\mathrm{Mo}-\mathrm{Pb}-\mathrm{Zn}$ mineralization in quartz veins and skarn with reported values as high as $0.15 \%$ Mo (fig. C-2).

37 Quartz Creek-Significant $\mathrm{Pb}-\mathrm{Zn}-\mathrm{Ag}$ mineralization; reported grades of $15 \%$ combined $\mathrm{Pb}-\mathrm{Zn}$ and $10 \mathrm{oz} / \mathrm{ton} \mathrm{Ag}$ (fig. C-1).

38 Placer River-Significant Mo-F mineralization disseminated in intrusive rocks. Reported values of $0.2 \%$ Mo (fig. C-2).

39 Fairhaven/Inmachuk district-Placer deposits with 348,924 oz production from 1902-2006; significant reserves remaining in a large ancestral channel system. Large base metal sulfide concentrations and $U$ values in concentrates (fig. C-3).

40 Poovookpuk Mountain-Porphyry Mo mineralization. Reported grades of up to $0.25 \% \mathrm{Mo}$ (fig. C-2).

41 Purcell Mountain-Mo and Ag occurrences associated with Cretaceous alkalic igneous plutons, alaskite, and bostonite dikes (fig. C-2).

42 Hughes mining district-Production of 289,104 oz Au from 1930 to 2006, mainly from Alaska Gold Co. dredge at Hogatza; dredge reactivated in 1981, but deactivated in 1984, and reactivated again in 1990. Non-float mechanized operation on Utopia Creek produced significant amount of placer Au from 1930 to 1962 (fig. C-3).

43 Iditarod district-Major placer Au district; produced 1,563,459 oz Au through 2006. Significant reserves of lode $\mathrm{Au}$ and lode $\mathrm{W}$ at Golden Horn deposit Chicken Mountain, and other known lodes in region associated with shear zones and monzonite intrusive rocks of Late Cretaceous age (fig. C-3).

44 Innoko-Tolstoi mining district-Major placer $\mathrm{Au}$ district with significant lode $\mathrm{Au}-\mathrm{Sb}-\mathrm{Hg}$ potential; lode sources are Late Cretaceous volcanic-plutonic complexes and dike swarms that intrude Mesozoic 
flysch; mining district produced 732,353 oz Au through 2006, almost all from placer deposits (fig. C-3).

45 Bonanza Creek-Skarn-type W mineralization along intrusive contact; no published information available (fig. C-2).

46 Ruby mining district-Placer $\mathrm{Au}-\mathrm{Sn}$ district; produced more than 477,976 oz Au from 1931 to 2006; mining district also contains $\mathrm{Pb}-\mathrm{Ag}$ prospects with grades reportedly as high as $82 \mathrm{oz} /$ ton $\mathrm{Ag}$ (fig. C-3).

47 Hot Springs mining district-Placer $\mathrm{Au}-\mathrm{Sn}$ district; produced more than 582,620 oz Au and over 720,000 lb cassiterite through 2006. Includes Eureka and Tofty subdistricts. Magnetite-rich, niobium-bearing carbonatite sill in the Tofty area contains geochemically anomalous Nb, REE, $\mathrm{P}$, and $\mathrm{Y}$ (figs. C-2, C-3).

48 Tolovana mining district-Placer Au district; produced more than 529,573 oz Au since discovery in 1914 to 2006. Substantial reserves remain mainly on Livengood Bench, a Pliocene ancestral channel (fig. C-3).

49 Fairbanks mining district-Nationally ranked Au-producing district; largest producer in Alaska. Produced about 8,197,458 oz Au from placer deposits (1902-2006). Major lode Au and lode Sb producer; produced more than 4,094,196 oz Au and over 2000 tons Sb from veins and shear zones through 2006. Production of W exceeded 4,000 short ton units since 1915, all derived from skarn near Cretaceous quartz monzonite (fig. C-3).

49a Fort Knox-Disseminated Au deposit within granodiorite/quartz monzonite pluton near Fairbanks. Proven and probable reserves as of December 31, 2006, open at depth, are 2,705,000 oz of Au in 176.0 million tons of rock at an average Au grade of 0.015 oz/ton. Measured and indicated resources are 70.69 million tons grading $0.018 \mathrm{oz} /$ ton Au containing $1,289,000$ ounces of gold, with 1,573,000 ounces of measured and indicated gold resources in the Fort Knox area. Fairbanks Gold Mining Inc. at Fort Knox and True North mines produced 3,676,284 oz of Au from 1996 to 2006 (fig. C-3).

49b Ryan Lode-Based on a 0.015 oz/ton cutoff, total reserves in the metasediment-hosted Ryan Lode and subparallel igneous-hosted Curlew Shear are 822,200 oz of Au in 14.6 million tons of rock. A geologic resource of about 2.4 million oz occurs within the total shear zone system (fig. C-3).

49c Grant Mine-Series of subparallel Au-bearing quartz veins in schist and quartzite of Ester Dome based on exploration in 1990. Indicated reserves one of the O’Dea vein system are 212,000 tons of $0.36 \mathrm{oz} /$ ton Au. Other similar vein systems are found nearby (fig. C-3).

49d True North-Au occurs in siderite-quartz veins in carbonaceous quartzite and schist within a terrane containing eclogitic rocks. An indicated resource of $188,000 \mathrm{oz} \mathrm{Au}$ at grade of $0.040 \mathrm{oz} /$ ton $\mathrm{Au}$ in
4,665,000 tons of rock as of December 31, 2006. 11.04 million tons of $0.04 \mathrm{oz} /$ ton ore were processed at Fort Knox mill from 2001 through 2004 (fig. C-3).

49e Dolphin-Mineralized intermediate intrusion contains anomalous Au, As, Bi and Sb. Discovery hole in 1995 intercepted $330 \mathrm{ft}$ of $0.049 \mathrm{oz} /$ ton Au (fig. C-3).

49f Gil Claims - Gold occurs in two calc-silicate zones within Paleozoic schist units. Gold enrichment occurs along iron-stained shears and within quartz-calcite veinlets. Drilling identified an in-place Au resource of $433,000 \mathrm{oz}$ at an average grade of $0.04 \mathrm{oz} / \mathrm{ton} \mathrm{Au}$ (fig. C-3).

50 Mt. Prindle - Significant U-rare-earth mineralization in Mesozoic alkaline igneous rocks. Rock geochemical values of up to $0.7 \% \mathrm{U}$; up to $15 \%$ rare-earth elements reported (fig. C-3).

51 Twin Mountain-Significant W mineralization associated with skarn development along contact zone of quartz monzonite stock of Cretaceous age (fig. C-2).

52 Circle mining district-Currently one of Alaska's largest producing placer Au districts; produced more than 1,068,860 oz Au since discovery in 1893 to 2006. Has significant potential for $\mathrm{Sn}, \mathrm{W}$, and $\mathrm{Au}$ mineralization from variety of lode sources (fig. C-3).

53 Three Castle Mountain, Pleasant Creek, Casca VABM-Stratabound $\mathrm{Pb}-\mathrm{Zn}$ massive sulfide mineralization. Reported grades of up to $17 \% \mathrm{Zn}$ and $2 \% \mathrm{~Pb}$ (fig. C- 1 ).

54 Bonnifield district massive sulfide deposits (Anderson Mountain, Dry Creek, Sheep Creek, Virginia Creek, BT, Liberty Bell)_-Significant volcanogenic $\mathrm{Cu}-\mathrm{Pb}-\mathrm{Zn}-\mathrm{Ag}$ massive sulfide deposits of Devonian to Mississippian age. Potential for high-grade deposits reported. Includes Liberty Bell stratabound $\mathrm{Au}-\mathrm{B}$ deposit and mineralization in Sheep Creek; latter contains $\mathrm{Sn}$ as well as base metals (fig. C-1).

55 Delta massive sulfide belt-Contains at least 30 known volcanogenic massive sulfide deposits and occurrences. Grades from 0.3 to $1.1 \% \mathrm{Cu}, 1.7$ to $5.7 \%$ $\mathrm{Zn}, 0.5$ to $2.3 \% \mathrm{~Pb}, 0.7$ to $2.0 \mathrm{oz} /$ ton $\mathrm{Ag}$, and 0.018 to $0.061 \mathrm{oz} /$ ton $\mathrm{Au}$; estimated potential reserve of 40 million tons for all deposits. Recent exploration has identified several gold prospects associated with silicified structures in the White Gold trend (fig. C-1).

56 Mosquito, Peternie - Porphyry Mo prospects of early Tertiary age; reported grades of up to $0.17 \%$ Mo (fig. C-2).

57 Taurus-Significant major porphyry $\mathrm{Cu}-\mathrm{Au}$ prospect of Paleocene age. East Taurus Zone contains inferred reserves of 140 million tons grading about $0.30 \% \mathrm{Cu}$ and $0.01 \mathrm{oz} /$ ton $\mathrm{Au}$, and $0.03 \% \mathrm{Mo}$ (fig. C-2).

58 Big Creek/Ladue - Stratabound $\mathrm{Pb}-\mathrm{Zn}-\mathrm{Ag}$ massive sulfide prospects in metavolcanic rocks (fig. C-1).

59 Slate Creek-At least 55 million tons of $6.3 \%$, highquality chrysotile asbestos in serpentinized ultramafic rocks of Permian(?) age (fig. C-3).

60 Fortymile mining district-Major placer Au district. Produced over 561,646 oz placer and very minor 
lode Au since discovery in 1883 to 2006, the longest continuous production of $\mathrm{Au}$ (120 years) of any Alaskan mining district (fig. C-3).

61 Kantishna mining district-Major placer $\mathrm{Au}$ and lode Ag-Au-Pb-Zn-Sb-W district. Produced 99,307 oz placer and lode Au, about 307,000 oz lode Ag, and 2,500 tons Sb from shear zones and vein deposits hosted in metamorphic units of Yukon-Tanana terrane. Nearly 90 lode deposits have been identified; potential exists for significant $\mathrm{Ag}-\mathrm{Au}-\mathrm{Pb}-\mathrm{Zn}$ resources.

Metalliferous stratabound base metal deposits occur in schist and quartzite (fig. C-3).

62 Stampede mine-Major Sb deposit; produced more than 1,750 tons Sb from large shear zone in poly-metamorphic rocks of Yukon-Tanana terrane (fig. C-3).

63 Coal Creek-Greisen-hosted Sn-Cu-W deposit in "McKinley" age pluton (55 million years old). Reported reserves of 5 million tons of ore that grade $0.28 \% \mathrm{Sn}$ and $0.3 \% \mathrm{Cu}$ with credits of $\mathrm{W}, \mathrm{Ag}$, and $\mathrm{Zn}$ (fig. C-2).

64 Golden Zone mine-Major $\mathrm{Au}-\mathrm{Cu}-\mathrm{Ag}$ deposits in Late Cretaceous breccia pipe and skarn deposits. Produced more than 1,581 oz Au, 8,617 oz Ag, and 21 tons $\mathrm{Cu}$. The Golden Zone deposit contains measured and indicated resources of approximately 2 million tons, grading $0.106 \mathrm{oz} /$ ton $\mathrm{Au}, 0.47 \mathrm{oz} /$ ton $\mathrm{Ag}$ and $0.12 \% \mathrm{Cu}$ (utilizing a $0.05 \mathrm{oz} /$ ton Au cut-off grade), and contains approximately 214,800 ounces of gold, 948,000 ounces of silver and 24,000 pounds of copper. (figs. C-1, C-3).

65 Nim Prospect-Porphyry $\mathrm{Cu}-\mathrm{Ag}$-Au deposit of Late Cretaceous age. Reported grades of up to $5.0 \% \mathrm{Cu}$ and 9 oz/ton Ag (fig. C-1).

66 Valdez Creek district-About 513,671 oz Au production through 2006. Cambior Alaska Inc., the largest placer mine in Alaska, operated in this district until September 1995 (fig. C-3).

67 Caribou Dome (Denali) - Ten identified stratabound $\mathrm{Cu}$ deposits in volcanic sedimentary rocks of Triassic age. Proven and probable ore is 700,000 tons grading $6 \% \mathrm{Cu}$ with Ag credits, with indicated resources that may contain 2 million tons ore over strike length of 4,000 feet (fig. C-1).

67a Zackly-Disseminated $\mathrm{Cu}$ and $\mathrm{Au}$ in garnet-pyroxene skarn and marble. Reserves are estimated at 1.4 million tons grading 2.6 percent $\mathrm{Cu}$ and $0.175 \mathrm{oz} /$ ton Au (fig. C-1).

68 Chistochina-Porphyry Cu prospects of Tertiary age and placer Au district; produced more than $182,719 \mathrm{oz}$ Au and small amount Pt from placer deposits through 2006 (figs. C-2, C-3).

69 Nabesna mine - Classic high-grade Au skarn that envelopes quartz diorite of Jurassic(?) age; produced over 66,500 oz Au from about 88,000 tons of ore from 1930 to 1941 (fig. C-3).

70 Spirit Mountain-Massive and disseminated $\mathrm{Cu}-\mathrm{Ni}$ mineralization in mafic-ultramafic complex (fig. C-3).

71 Kennecott deposits-Major stratiform $\mathrm{Cu}-\mathrm{Ag}$ massive sulfide deposits localized near contact between Chitistone Limestone and Nikolai Greenstone of Triassic age; contained some of highest grade $\mathrm{Cu}$ lodes mined in North America. From 1911 to 1938, produced more than 600,000 tons $\mathrm{Cu}$ and 10 million oz Ag from 4.8 million tons ore. Some reserves remain (fig. C-1).

72 Binocular and other prospects-Kennecott-type $\mathrm{Cu}-\mathrm{Ag}$ massive sulfide deposits (fig. C-1).

73 Bond Creek-Orange Hill-Two major porphyry $\mathrm{Cu}-\mathrm{Mo}$ deposits of Late Cretaceous age; reported inferred reserves of 850 million tons ore that grade 0.3 to $0.5 \% \mathrm{Cu}$ and $0.03 \% \mathrm{Mo}$ (fig. C-2).

74 Carl Creek-Porphyry Cu prospect in altered intrusive complex; similar to locality 73 (fig. C-2).

75 Baultoff-Porphyry Cu prospect in altered intrusive rocks; inferred reserves of 145 million tons of $0.20 \%$ $\mathrm{Cu}$; similar to locality 73 (fig. C-2).

76 Horsfeld-Porphyry Cu prospect of Late Cretaceous age (fig. C-2).

77 Midas mine - Significant stratabound $\mathrm{Cu}$ (Ag$\mathrm{Au}-\mathrm{Pb}-\mathrm{Zn}$ ) massive sulfide deposit in volcanic sedimentary rocks of Tertiary Orca Group. Produced more than 1,650 tons $\mathrm{Cu}$ from 49,350 tons ore (fig. C-1).

78 Ellamar-Stratabound $\mathrm{Cu}-\mathrm{Zn}-\mathrm{Au}$ massive sulfide deposit in sediment of Eocene(?) Orca Group. Produced more than 8,000 tons $\mathrm{Cu}, 51,307 \mathrm{oz} \mathrm{Au}$, and 191,615 oz Ag from about 301,835 tons ore (fig. C-1).

79 Willow Creek, Independence, Lucky Shot, War Baby-Major lode Au deposits (Ag-Cu-Pb-Zn-Mo) in veins cutting Mesozoic quartz diorite. Produced more than 606,400 oz Au from lode sources and about 55,600 oz Au from associated placer deposits (fig. C-3).

80 Latouche, Beatson-Major stratabound $\mathrm{Cu}-\mathrm{Zn}-\mathrm{Ag}$ massive sulfide deposits in Orca Group sedimentary rocks and mafic volcanic rocks. Produced more than 10,250 tons $\mathrm{Cu}$ from 6 million tons ore. Inferred reserves of 5 million tons ore that grade $1 \% \mathrm{Cu}, 1.5 \%$ $\mathrm{Pb}+\mathrm{Zn}$ (fig. C-1).

81 Rua Cove-Major stratabound $\mathrm{Cu}-\mathrm{Zn}$ massive sulfide deposit in complex ore shoots enclosed in mafic volcanic rocks of Orca Group. Reported reserves of over 1.1 million tons ore that grade $1.25 \% \mathrm{Cu}$ (fig. C-1).

82 Red Mountain and Claim Point-Significant Cr occurrences associated with Jurassic layered ultramafic complexes at Red Mountain near Seldovia. More than 39,951 tons of metallurgical-grade ore shipped through 1976; huge low-grade $\mathrm{Cr}$ resource may remain, of which 30 million tons grade $5.1 \%$ Cr2O3 (fig. C-3).

83 Red Devil-Major Hg-Sb deposit; high-grade epithermal $\mathrm{Hg}-\mathrm{Sb}$ deposit hosted in shear zones in Kuskokwim Group sedimentary rocks. More than 35,000 flasks $\mathrm{Hg}$ produced from 75,000 tons ore (fig. C-3).

84 Aniak district-Significant placer Au district with 595,366 oz Au produced through 2006, mainly from the Nyac and Donlin Creek areas (fig. C-3). 
85 Goodnews Bay-Major placer Pt district; estimated to have produced over 555,000 oz refined PGE metals from 1934 to 1976; one of the largest known PGE metal resources in United States. Possible resources of 60 million yd3 of deep, PGE-bearing gravels remain. Lode source believed to be Alaskan-type zoned ultramafic complex of Jurassic or Cretaceous age. Possible significant offshore placer potential (fig. C-3).

86 Apollo-Sitka mines-Major lode Au deposits; produced more than $107,600 \mathrm{oz}$ Au from ore that averaged about $0.22 \mathrm{oz} /$ ton $\mathrm{Au}$. Inferred reserves are 748,000 tons grading $0.76 \mathrm{oz} /$ ton $\mathrm{Au}, 2.16 \mathrm{oz} /$ ton $\mathrm{Ag}$, with base metal credits (fig. C-3).

87 Pyramid - Late Tertiary porphyry $\mathrm{Cu}-\mathrm{Mo}$ deposit; inferred reserves of 125 million tons ore that grade $0.4 \% \mathrm{Cu}$ and $0.03 \%$ Mo reported (fig. C-2).

88 Ivanof-Late Tertiary porphyry Cu prospect; grades of up to $0.72 \% \mathrm{Cu}$ reported. Potential for large tonnages (fig. C-2).

89 Weasel Mountain, Bee Creek-Porphyry $\mathrm{Cu}-\mathrm{Mo}$ prospect of late Tertiary to Quaternary age; grades of up to $0.48 \% \mathrm{Cu}$ and $0.035 \%$ Mo reported. Potential for moderate tonnages of low-grade mineralization (fig. C-2).

90 Mike deposit-Porphyry Mo prospect of late Tertiary age; grades up to $0.21 \%$ Mo. Potential for large tonnages of low-grade Mo mineralization (fig. C-2).

91 Rex deposit-Porphyry Cu prospect similar to locality 90; grades up to $0.3 \% \mathrm{Cu}$. Potential for moderate reserves of low-grade mineralization (fig. C-2).

92 Kasna Creek-Major stratiform $\mathrm{Cu}-\mathrm{Pb}-\mathrm{Zn}$ and skarn-sulfide deposits of Mesozoic age in mafic, volcanic, and sedimentary rocks; reported reserves of over 10 million tons ore that grade more than $1 \% \mathrm{Cu}$ (fig. C-1).

93 Sleitat Mountain-High-grade east-west-trending, Sn-W-Ag topaz-quartz greisen system hosted in 59-million-year-old granite and in hornfels. Zone up to 3,000 ft long and $500 \mathrm{ft}$ wide. One drill-hole with $85 \mathrm{ft}$ of $1.8 \% \mathrm{Sn}$, and $0.4 \% \mathrm{~W}$. Inferred resources up to 106,000 tons $\mathrm{Sn}$ in 29 million tons ore (fig. C-2).

94 Jimmy Lake-Complex Cu-Ag-Sn mineralization of late Tertiary(?) age; reported grades of up to 105 oz/ton $\mathrm{Ag}$ and $3 \% \mathrm{Cu}$ (fig. C-1).

95 Haines Barite/Palmer-Major stratiform Ba-Pb-Zn$\mathrm{Cu}-\mathrm{Ag}$ deposit in pillow basalt-dominated section of Paleozoic or Triassic age; consists of 48- to 60-ft-thick zone of $60 \%$ barite with upper zone ( 2 to $8 \mathrm{ft}$ thick) of massive sulfides that contain $2 \% \mathrm{~Pb}, 3 \% \mathrm{Zn}, 1 \% \mathrm{Cu}$, up to $4 \mathrm{oz} /$ ton $\mathrm{Ag}$, and $0.12 \mathrm{oz} /$ ton Au. Estimated to contain 750,000 tons of $65 \%$ barite with $\mathrm{Zn}$ and $\mathrm{Ag}$ credits (fig. C-1).

96 Klukwan-Major Fe-Ti deposits in zoned ultramafic complex of Mesozoic age; reported to contain 3 billion tons of material grading $16.8 \% \mathrm{Fe}$ and 1.6 to $3.0 \% \mathrm{Ti}$ (fig. C-3).

97 Nunatak-Porphyry Mo deposit; reported reserves of 2.24 million tons ore grading $0.067 \% \mathrm{Mo}, 0.16 \%$ $\mathrm{Cu}$, and 129.5 million tons of $0.026 \% \mathrm{Mo}, 0.18 \% \mathrm{Cu}$ (fig. C-2).
98 Brady Glacier-Major Ni-Cu deposit in layered gabbro-pyroxenite complex of Tertiary age. Proven reserves of 100 million tons ore that grade $0.5 \% \mathrm{Ni}$, $0.3 \% \mathrm{Cu}$ reported and about $0.03 \% \mathrm{Co}$; also contains PGE concentrations (fig. C-3).

99 Mertie Lode and Funter Bay-Contains substantial reserves of lode Au mineralization. Past production totaled about 15,000 oz Au. Deposits also contain significant $\mathrm{Ni}-\mathrm{Cu}$ and $\mathrm{Pb}-\mathrm{Zn}-\mathrm{Ag}$ mineralization. Funter Bay deposit contains reported reserves of 560,000 tons that grade $0.34 \% \mathrm{Ni}, 0.35 \% \mathrm{Cu}$, and $0.15 \%$ Co in gabbro-pipe system (fig. C-3).

100 Alaska-Juneau-Major lode Au deposit that consists of 100- to 300-ft-wide zone that contains en echelon, $\mathrm{Au}$-bearing quartz veins in metamorphic rocks; produced more than 3.52 million oz Au from 88.5 million tons ore from 1893 to 1944 . Reserves (all categories) of 105.7 million tons of $0.05 \mathrm{oz} / \mathrm{ton} \mathrm{Au}$ (fig. C-3).

101 Chichagof and Hirst Chichagof-Major lode $\mathrm{Au}$ deposits in quartz veins that cut Mesozoic graywacke; produced more than 770,000 oz Au, most of which was produced at Chichagof Mine. Inferred leased reserves estimated to be $100,000 \mathrm{oz} \mathrm{Au}$ (fig. C-3).

102 Mirror Harbor- $-\mathrm{Ni}-\mathrm{Cu}$ mineralization in layered gabbro complex of Mesozoic age; reported proven reserves of 8,000 tons of $1.57 \% \mathrm{Ni}$ and $0.88 \% \mathrm{Cu}$ and reported inferred reserves of several million tons ore that grade $0.2 \% \mathrm{Ni}$ and $0.1 \% \mathrm{Cu}$ (fig. C-3).

103 Bohemia Basin-Major Ni-Cu-Co mineralization in layered mafic complex similar to locality 102; reported reserves of 22 million tons ore that grade 0.33 to $0.51 \% \mathrm{Ni}, 0.21$ to $0.27 \% \mathrm{Cu}$, and $0.02 \%$ Co, all of which are recoverable with standard flotation technology (fig. C-3).

104 Apex-EI Nido-Significant lode Au-W deposits occurring as cross-cutting veins in graywacke; produced more than 50,000 oz Au (fig. C-3).

105 Greens Creek-Major sediment-hosted $\mathrm{Pb}-\mathrm{Zn}$ $\mathrm{Cu}-\mathrm{Ag}-\mathrm{Au}$ volcanogenic massive sulfide deposit of Devonian or Triassic age. Production from 1989 to 1993 and 1996 to 2006 is 989,769 tons of Zn, 302,493 tons of $\mathrm{Pb}$, over 8,600 tons of $\mathrm{Cu}, 135.4$ million oz of Ag, and 982,216 oz of Au. 2006 probable reserve estimate is 7.68 million tons grading $10.39 \% \mathrm{Zn}$, $3.98 \% \mathrm{~Pb}, 14.42 \mathrm{oz} / \mathrm{ton} \mathrm{Ag}$, and $0.113 \mathrm{oz} /$ ton $\mathrm{Au}$. Inferred resources are 5.07 million tons grading 10.4\% $\mathrm{Zn}, 4.0 \% \mathrm{~Pb}, 0.113 \mathrm{oz} / \mathrm{ton} \mathrm{Au}$, and $14.42 \mathrm{oz} / \mathrm{ton} \mathrm{Ag}$. (fig. C-1).

106 Sumdum - Volcanogenic $\mathrm{Cu}-\mathrm{Pb}-\mathrm{Zn}$ massive sulfide deposit in Mesozoic metamorphic complex with potential strike length of over 10,000 ft. Inferred reserves of 26.7 million tons ore that grade $0.57 \% \mathrm{Cu}$, $0.37 \% \mathrm{Zn}$, and $0.3 \mathrm{oz} / \mathrm{ton} \mathrm{Ag}$ reported (fig. C-1).

107 Snettisham-Fe-Ti deposit in mafic zoned intrusive complex; reported grades of about $18.9 \%$ Fe and $2.6 \%$ Ti (fig. C-3).

108 Tracy Arm - Stratabound $\mathrm{Cu}-\mathrm{Zn}-\mathrm{Pb}$ massive sulfide prospect in Mesozoic schist; over 1,100 ft long and up to $12 \mathrm{ft}$ thick. Reported grades of $1.5 \% \mathrm{Cu}, 3.9 \% \mathrm{Zn}$, $0.76 \mathrm{oz} / \mathrm{ton} \mathrm{Ag}$, and $0.013 \mathrm{oz} /$ ton Au (fig. C-1). 
109 Red Bluff Bay-Significant chrome mineralization in Mesozoic ultramafic complex (probably ophiolite); reported reserves of 570 tons of material that grade $40 \% \mathrm{Cr}$ and 29,000 tons that grade 18 to $35 \% \mathrm{Cr}$ (fig. C-3).

110 Cornwallis Peninsula-Volcanogenic $\mathrm{Cu}-\mathrm{Pb}-\mathrm{Zn}-$ Ag-Ba massive sulfide deposit of Triassic(?) age; reported grades of up to $20 \% \mathrm{~Pb}-\mathrm{Zn}$ and $23 \mathrm{oz} / \mathrm{ton} \mathrm{Ag}$ (fig. C-1).

111 Castle Island - Stratiform barite deposit of Triassic age hosted in carbonate and pillow basalt; about 856,000 tons of raw and refined barite produced from 1963 to 1980; also contains Zn, Pb, and Cu sulfides. Reported to be mined out (fig. C-1).

112 Groundhog Basin-Area with several massive sulfide prospects in Mesozoic schist and gneiss whose origins are possibly plutonic associated. Reported grades of up to $8 \% \mathrm{~Pb}, 29 \mathrm{oz} /$ ton $\mathrm{Ag}$, and $0.5 \mathrm{oz} /$ ton $\mathrm{Au}$. Sn has also been recently identified. Area also contains potential for porphyry Mo deposits (fig. C-1).

113 Snipe Bay-Ni-Cu deposit in zoned mafic-ultramafic complex; inferred reserves of 430,000 tons of $0.3 \%$ $\mathrm{Ni}, 0.3 \% \mathrm{Cu}$, and $0.13 \mathrm{oz} / \mathrm{ton} \mathrm{Ag}$ reported (fig. C-3).

114 Kasaan Peninsula-Major skarn-type $\mathrm{Cu}-\mathrm{Fe}-\mathrm{Au}$ massive sulfide deposit of Jurassic age; area has produced over 14,000 tons $\mathrm{Cu}$, and 55,000 oz Ag. Reported reserves of 4 million tons ore that grade $50 \%$ Fe and less than $2 \% \mathrm{Cu}$ (fig. C-1).

115 Salt Chuck-Cu-PGM-Ag-Au deposit in contact zone between pyroxenite and gabbro within Alaskantype zoned mafic-ultramafic pluton. From 1900 to 1941, 2,500 tons $\mathrm{Cu}$, over 20,000 oz PGM, and $\mathrm{Au}$ and Ag credits were produced from 325,000 tons ore (fig. C-3).

116 Union Bay-Significant Fe-Ti-(V) mineralization in zoned, Ural-Alaska type ultramafic complex At least 7 zones of PGE-magnetite hydrothermal mineralization associated with pyroxene veins that crosscut magmatic layering (fig. C-3).

117 Hyder mining district-Area produced more than 25,000 tons high-grade $\mathrm{W}-\mathrm{Cu}-\mathrm{Pb}-\mathrm{Zn}-\mathrm{Ag}$ ore from 1925 to 1951 from crosscutting ore shoots in Texas Creek granodiorite of Tertiary age. Area contains potential for porphyry Mo-W mineralization and massive sulfide-skarn $\mathrm{Pb}-\mathrm{Ag}-\mathrm{Au}-\mathrm{W}$ deposits (figs. C-1, C-2).

118 Jumbo-Cu-Fe-Mo-Ag skarn deposit; produced more than 5,000 tons $\mathrm{Cu}, 280,000 \mathrm{oz} \mathrm{Ag}$, and 7,000 oz Au from 125,000 tons ore. Zoned magnetite-Cu skarns are associated with epizonal granodiorite pluton of Cretaceous age. Reported reserves of 650,000 tons ore that grade $45.2 \% \mathrm{Fe}, 0.75 \% \mathrm{Cu}, 0.01 \mathrm{oz} /$ ton $\mathrm{Au}$, and $0.08 \mathrm{oz} /$ ton $\mathrm{Ag}$ (fig. C-1).

119 Copper City-Stratiform Cu-Zn-Ag-Au massive sulfide deposit in late Precambrian or earliest Paleozoic Wales Group. Reported grades of up to $12.7 \% \mathrm{Cu}, 2.7 \% \mathrm{Zn}, 2.5 \mathrm{oz} / \mathrm{ton} \mathrm{Ag}$, and $0.2 \mathrm{oz} /$ ton $\mathrm{Au}$ (fig. C-1).

120 Quartz Hill-A porphyry Mo deposit hosted in a 25-million-year-old composite felsic pluton. Probable reserves are 232 million tons with a grade of $0.22 \%$ MoS2, and possible reserves are 1.2 billion tons with $0.12 \% \mathrm{MoS} 2$ (fig. C-2).

121 Niblack-Volcanogenic $\mathrm{Cu}-\mathrm{Pb}-\mathrm{Au}-\mathrm{Ag}$ massive sulfide deposit hosted in Precambrian(?) Wales Group or Ordovician to Silurian Descon Formation; produced more than 700 tons $\mathrm{Cu}, 11,000 \mathrm{oz} \mathrm{Au}$, and 15,000 oz Ag. Resource of 2.78 million tons at $3.22 \% \mathrm{Zn}, 1.70 \%$ $\mathrm{Cu}, 0.93 \mathrm{oz} /$ ton $\mathrm{Ag}$ and $0.081 \mathrm{oz} / \mathrm{ton} \mathrm{Au}$. (fig. C-1).

122 Bokan Mountain-Numerous U-Th prospects associated with Jurassic peralkaline intrusive complex; from 1955 to 1971, produced more than 120,000 tons ore that graded about $1 \%$ U3O8. Contains inferred reserves of about 40 million tons of $0.126 \% \mathrm{Nb}$ and up to $1 \%$ REE metals (fig. C-3).

123 Kemuk Mountain-Magmatic Fe-Ti deposit hosted in Cretaceous(?) pyroxenite. Inferred reserves of 2.4 billion tons that average 15 to $17 \% \mathrm{Fe}, 2$ to $3 \% \mathrm{TiO} 2$, and $0.16 \% \mathrm{P}_{2} \mathrm{O} 5$ (fig. C-3).

124 McLeod-Porphyry Mo deposit that contains quartzmolybdenite fissure veins in quartz-feldspar porphyry. Chip samples contain up to $0.09 \%$ Mo (fig. C-2).

125 Johnson River-Epigenetic(?) quartz-sulfide stockwork or massive sulfide deposit hosted in volcaniclastic, pyroclastic, and volcanic rocks of Jurassic Talkeetna Formation. Deposit has drilledout reserves at a $\$ 45 /$ ton cutoff with no cut of high Au assays, 1,099,580 tons grading $0.32 \mathrm{oz} /$ ton $\mathrm{Au}$, $0.24 \mathrm{oz} /$ ton $\mathrm{Ag}, 0.76 \% \mathrm{Cu}, 1.17 \% \mathrm{~Pb}$, and $8.37 \% \mathrm{Zn}$ (fig. C-3).

126 Nimiuktuk River-Small hill of massive, high-grade barite estimated to contain at least 1.5 million tons barite. Widespread stream-sediment $\mathrm{Ba}$ anomalies in area indicate further barite potential (fig. C-1).

127 Kensington-Stockwork quartz veins in sheared and chloritized quartz diorite produced 10,900 tons grading $0.18 \mathrm{oz} /$ ton Au prior to 1930. Recent estimates indicate at least 4.42 million tons grading $0.31 \mathrm{oz} /$ ton Au for 1,352,140 oz Au of proven and probable reserves and 4.32 million tons of mineralized material grading 0.20 oz/ton Au (fig. C-3).

128 Jualin-Five quartz-fissure veins in Cretaceous quartz diorite, more than 15,000 ft of underground workings; produced 48,387 oz Au, mainly prior to 1930 . Reserves included in the reserves of the Kensington property (fig. C-3).

129 Pebble (Copper) - One of the world's largest $\mathrm{Cu}-\mathrm{Au}$ porphyry deposits with several known centers. The Pebble West deposit has a measured, indicated and inferred resource of 2.04 billion tons grading $0.34 \%$ $\mathrm{Cu}, 0.011 \mathrm{oz} /$ ton $\mathrm{Au}$ and $0.018 \% \mathrm{Mo}$ at a $0.50 \% \mathrm{Cu}$ equivalent cutoff. The new Pebble East deposit has an inferred resource of 3.75 billion tons grading $0.57 \%$ $\mathrm{Cu}, 0.011 \mathrm{oz} /$ ton $\mathrm{Au}$ and $0.036 \% \mathrm{Mo}$ at a $0.60 \%$ $\mathrm{Cu}$ equivalent cutoff. The 2007 combined resource contains 67 billion pounds of copper, 82 million ounces of gold and 5.2 billion pounds of molybdenum. Mineralized system extends over 35 square mile area and includes other $\mathrm{Cu}-\mathrm{Au}-\mathrm{Mo}$ porphyry, $\mathrm{Cu}-\mathrm{Au}$ skarn, and Au vein prospects (fig. C-1). 
130 Pogo - Au hosted in at least three sub-parallel and tabular, gently dipping, quartz vein zones hosted by Paleozoic gneisses intruded by Cretaceous felsic plutonic rocks. Au in the $3 \mathrm{ft}$ to $60 \mathrm{ft}$ thick quartz bodies has a strong correlation with $\mathrm{Bi}$. A mining reserve for the Liese $\mathrm{L} 1$ and $\mathrm{L} 2$ zones is 7.7 million tons at an average grade of $0.47 \mathrm{oz} / \mathrm{ton}$, for a total of 3.63 million oz at a $0.1 \mathrm{oz} /$ ton cut-off grade. Produced 113,364 ounces of gold in 2006. Other high-grade $\mathrm{Au}$ targets have been identified along an 8-mi-long trend southeast of the Liese zones (fig. C-3).

131 Shotgun-Quartz stockwork and breccia $\mathrm{Au}-\mathrm{Cu}-\mathrm{As}$ mineralization in a Late Cretaceous rhyolite (granite porphyry) stock. A preliminary, inferred Au resource of 980,000 oz (36.11 million tons at an average grade of $0.027 \mathrm{oz} /$ ton $\mathrm{Au}$ ) at a $0.016 \mathrm{oz} /$ ton Au cut-off grade, with initial metallurgical tests indicating $>90 \% \mathrm{Au}$ recovery by cyanide leaching (fig. $\mathrm{C}-3$ ).

132 Illinois Creek-Au-Ag-Cu-Pb-Zn-Bi-As-bearing, Fe-Mn oxide (gossan) shear zone crosscutting dolomitic quartzite localized near Cretaceous granitic pluton. Shear zone averaged $148 \mathrm{ft}$ wide, with a drilldefined east-west strike length of 11,600 ft. Produced approximately 143,860 oz Au and 755,600 oz Ag from 1997 to 2004. Past ore grade of $0.076 \mathrm{oz} /$ ton Au and $1.6 \mathrm{oz} / \mathrm{ton}$ Ag (figs. C-1, C-3).

133 Calder Mine-Seven recrystallized carbonate units exposed at the apex of a large regional antiform. Drilling has identified 13 million tons of chemically homogenous, high-brightness, high-whiteness marble with a purity of 98 to $99 \%$ calcium carbonate. Potential resource of 80 million tons of high-value calcium carbonate (fig. C-2).

134 Vinasale Mountain-Intrusion-hosted Au deposit. Au occurs as disseminated and veinlet mineralization, with arsenopyrite and pyrite in quartz-dolomite hydrothermal breccias, magmatic breccias, and zones of phyllic and silicic alteration hosted within a $69 \mathrm{Ma}$ quartz monzonite stock. Inferred resource of 14.35 million tons grading $0.067 \mathrm{oz} /$ ton $\mathrm{Au}$, with an $0.03 \mathrm{oz} /$ ton cut-off grade was for the Central zone (fig. C-3).

135 Nixon Fork-Au-Cu skarn deposits; Historic Nixon Fork mine produced 59,500 oz Au from Late Cretaceous skarns associated with quartz monzoniteDevonian limestone contact zones. Underground mining resumed in October 1995, with 137,748 oz of $\mathrm{Au}, 1,050$ tons of $\mathrm{Cu}$, and significant Ag produced through mine closure in 1999. 2006 ore resources and reserves are 25,787 tons grading $1.07 \mathrm{oz} /$ ton
$\mathrm{Au}$ (measured), 138,852 tons grading $0.63 \mathrm{oz} / \mathrm{ton}$ (indicated), and 102,486 tons grading $0.45 \mathrm{oz} / \mathrm{ton}$ (inferred), with proven reserves of 51,800 tons grading $0.993 \mathrm{oz} /$ ton $\mathrm{Au}$ and probable reserves of 151,600 tons grading $0.54 \mathrm{oz} /$ ton $\mathrm{Au}$, for a total of 295,430 ounces of gold (fig. C-3). .

136 Von Frank Mountain-Au and very weak $\mathrm{Cu}$ mineralization are associated with chalcopyrite, pyrite, and rare molybdenite within a zone of quartz stockwork veining hosted in a 69 Ma quartz-diorite stock. The stock is a cupola of the larger Von Frank Pluton. Drill intercepts include up to $429 \mathrm{ft}$ wide with an average grade of $0.013 \mathrm{oz} /$ ton Au. Higher-grade intercepts include $0.035 \mathrm{oz} /$ ton Au up to $135 \mathrm{ft}$ (fig. C-3).

137 Donlin Creek-Au mineralization associated with disseminated pyrite and arsenopyrite, sulfide veinlets, and quartz-carbonate-sulfide veinlets in sericite-altered Late Cretaceous to early Tertiary rhyodacitic porphyry dikes and sills. Au mineralization is structurally controlled, refractory, and occurs along a 4-mile long, 1-mile wide zone. 2006 measured and indicated resource estimated at 16.6 million oz of Au grading $0.070 \mathrm{oz} /$ ton $\mathrm{Au}$ and an inferred resource of 17.1 million oz Au grading $0.068 \mathrm{oz} /$ ton $\mathrm{Au}$ at a $0.022 \mathrm{oz} /$ ton Au cut-off grade. Considered the 25th largest gold resource in the world (fig. C-3).

138 Kaiyah-Au-Ag epithermal prospect in silicified Koyukuk sedimentary rocks adjacent to Poison Creek caldera. Polymetallic sulfides in quartz veins, with some veins over 100 feet thick, and silicification are associated with pervasive advanced argillic, and sericite alteration (fig. C-3).

139 Shulin Lake-Micro-and macro-diamonds occur in interbedded volcaniclastic and tuffaceous rocks containing olivine and pyroxene. Discovered by tracing diamond indicator minerals in placer gravels. Possibly lamproitic intrusions with up to 1-mile diameter circular aeromagnetic anomalies (fig. C-3).

140 Canwell and Nikolai Complex-Ni-Cu-PGE semimassive to massive sulfide prospects hosted in mafic and ultramafic rocks of the Nikolai intrusive/extrusive complex. Five mafic-ultramafic intrusions in the central Alaska Range are comagmatic with the Nikolai flood basalts (fig. C-3).

141 Duke Island-Cu-Ni-PGE disseminated, semimassive, and massive sulfides associated with 2 zoned, Ural-Alaska type ultramafic bodies (fig. C-3). 
APPENDIX D

Companies and individuals reported to be producing metal in Alaska, 2007

\begin{tabular}{|c|c|c|c|}
\hline Operator & Creek & District & Typea \\
\hline \multicolumn{4}{|c|}{ NORTHERN REGION } \\
\hline Barry Lambeth & Jennie Creek & Koyukuk & S/D - Recreation \\
\hline Bill Feses & Boulder Creek & Koyukuk & O/P Placer \\
\hline Brian Yoder & Sheep Creek & Koyukuk & O/P Placer \\
\hline Boreal Resources Inc. & Jim Pup, Wakeup Cr., California Cr., Lake Cr. & Koyukuk & $\mathrm{O} / \mathrm{P}$ Placer \\
\hline Chester Bell & Emery Creek & Koyukuk & S/D - Recreation \\
\hline Compass Mining Inc. & Linda Creek & Koyukuk & O/P Placer \\
\hline D.M.V.G. Ventures & Prospect Creek & Koyukuk & O/P Placer \\
\hline Donald Korte & Clara Creek & Koyukuk & S/D - Recreation \\
\hline Glen DeFord & Smally Creek & Koyukuk & S/D - Recreation \\
\hline James Wicken & Gold Creek & Koyukuk & O/P Placer \\
\hline Jay Armstrong & Hammond River & Koyukuk & S/D - Large \\
\hline Jim Olmstead & Gold Creek & Koyukuk & O/P Placer \\
\hline Larry Weisz & Hammond River & Koyukuk & O/P Placer \\
\hline Lloyd Swenson & Slate Creek & Koyukuk & O/P Placer \\
\hline Mike Dobson & Prospect Creek & Koyukuk & O/P Placer \\
\hline O.J. Jiles & Bold Bottom Creek & Koyukuk & O/P Placer \\
\hline Paradise Valley Inc. & Birch Creek & Koyukuk & S/D - Recreation \\
\hline Richard Wright & Magnet Creek, Gold Creek & Koyukuk & O/P Placer \\
\hline Silverado Gold Mines Ltd. & Nolan Creek & Koyukuk & O/P Placer \\
\hline Slisco Inc. & Hammond River & Koyukuk & O/P Placer \\
\hline Slisco Inc. & Hammond River & Koyukuk & O/P Placer \\
\hline Slisco Inc. & Hammond River & Koyukuk & O/P Placer \\
\hline Slisco Inc. & Marion Creek & Koyukuk & O/P Placer \\
\hline Slisco Inc. & Nugget Creek & Koyukuk & O/P Placer \\
\hline Stewart Brandon & Myrtle Creek & Koyukuk & O/P Placer \\
\hline Teck Cominco Alaska Inc. & Red Dog Mine & Noatak & $\mathrm{O} / \mathrm{P} \mathrm{H} / \mathrm{R}$ \\
\hline William Nordeen & Emma Creek & Koyukuk & O/P Placer \\
\hline \multicolumn{4}{|c|}{ WESTERN REGION } \\
\hline Alaska Gold Company & Norton Sound & Nome & S/D - Large \\
\hline Alamin Mining Company & Cripple Creek, Bear Creek & Innoko & O/P Placer \\
\hline Barry Clay & Willow Lake, Swift Creek & Ruby & O/P Placer \\
\hline Clifton McHenry & Norton Sound & Cape Nome & S/D - Large \\
\hline Craig Coggins & Norton Sound & Cape Nome & S/D - Large \\
\hline Daniel Plano & Anvil Creek, Innoko River & Innoko & O/P Placer \\
\hline Danny Bowland & Norton Sound & Cape Nome & S/D - Large \\
\hline David Powell & Norton Sound & Cape Nome & S/D - Large \\
\hline Dean Race & Anvil Creek, Innoko River & Cape Nome & O/P Placer \\
\hline Donald Mullikin & Noxapaga River, Boulder Creek & Kougarok & O/P Placer \\
\hline Douglas Martinson & Dry Creek, Newton Creek & Cape Nome & O/P Placer \\
\hline Frank McFarland & Norton Sound & Cape Nome & S/D - Large \\
\hline Innoko Resources Group & Innoko River & Innoko & O/P Placer \\
\hline Jan Kralik & Gold Run Creek & Point Clarence & S/D - Large \\
\hline Jan Kralik & Norton Sound & Cape Nome & S/D - Recreation \\
\hline Jerry Landgreba & Norton Sound & Cape Nome & S/D - Recreation \\
\hline Jerry Pushcar & Benson Creek & Kougarok & O/P Placer \\
\hline K \& S Leasing & Norton Sound & Cape Nome & S/D - Large \\
\hline Lawrence Essad & Norton Sound & Cape Nome & S/D - Large \\
\hline Little Creek Mine & Ester Creek & Innoko & $\mathrm{O} / \mathrm{P}$ Placer \\
\hline Mark Gumaer & Dick Creek & Kougarok & O/P Placer \\
\hline Mystery Creek Resources Ltd. & Nixon Fork Mine & McGrath & U/G HR \\
\hline
\end{tabular}

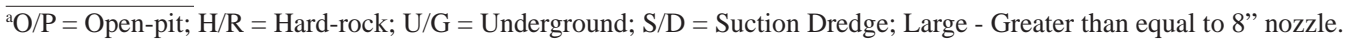

S/D - Recreation = small suction dredge and recreational operations. Prepared from list of permitted operations; not all produced during the year. 
Operator

Creek

District

N.B. Tweet \& Sons

Neil Rosander

Perry Massie

Ralph Anderson

Randall Smith

Robin Gumaer

Roger Nordlum

Rosander Mining Co., Inc.

Samuel Thomas

Steve Pomrenke

Taiga Mining Company, Inc.

Thomas Blake

Thomas Stamps

Triple D Mining

Tundra Services

Victor Loyer

Alaska Placer

Development, Inc.

Albert Oldham

Aurora Mining

Big G Mining

Bill Bayless

Bill Miller

Bill Rushing

C. J. Hill

Cascade Gold, LLC

Charles Hammond

Charles Zimmerman

Chris Groppel

Chuck Felzien

Cy Bras

D. Harvey Bickell

Daniel Jensen

David Eberhardt

David Hatch

David Howland

David Jacobs

David Jacobs

David Newcomb

Dean Willis

DEPEM

Diversified Mining Ventures

Doug Baker

Don Kiehl

Donald Smithwick

Earl Schene

Earl Vegoren

Earth Movers of Fairbanks

Earth Movers of Fairbanks

Eileen Crouse

Fairbanks Gold Mining Inc.

Fairbanks Gold Mining Inc.

40 Mile River Gold Mining C

Fred Cornelius

Frontier Mining
Kougarok River

Cripple Creek

Arctic Creek

Dry Creek

Norton Sound

Doree Creek

Glacier Creek

Colorado Creek

Sweepstakes Creek

Martin Creek

Aloha Creek

Dome Creek

Norton Sound

Candle Creek

Dexter Creek

Candle Creek

\section{EASTERN INTERIOR}

Livengood Creek

Wilber Creek

North Fork Harrison Creek

Deadwood Creek

Franklin Creek

Jack Wade

Jack Wade

Lost Chicken Creek

Walker Fork

45 Pup

Killarney Creek

Tenderfoot Creek

American Creek

Canyon Creek

Walker Fork

McCumber Creek

Sullivan Creek

Dome Creek

Dry Channel

Moose Creek

Eva Creek, Wilson Creek

Crooked Creek

Gilmore Creek

Clifford Creek

Cache Creek, Sullivan Creek, Idaho Creek

Gold King Creek

Crooked Creek

Uhler Creek

Rainy Creek

Fairbanks Creek

Chatham Creek

Fox Gulch

Fort Knox Mine

True North Mine

o. Fortymile River

Fox Creek

Butte Creek
White Creek

$\begin{array}{ll}\text { Kougarok } & \text { O/P Placer } \\ \text { Innoko } & \text { O/P Placer } \\ \text { Cape Nome } & \text { S/D - Recreation } \\ \text { Cape Nome } & \text { O/P Placer } \\ \text { Cape Nome } & \text { S/D - Large } \\ \text { Cape Nome } & \text { O/P Placer } \\ \text { Fairhaven } & \text { O/P Placer } \\ \text { Innoko } & \text { O/P Placer } \\ \text { Koyuk } & \text { O/P Placer } \\ \text { Cape Nome } & \text { O/P Placer } \\ \text { Hughes } & \text { O/P Placer } \\ \text { Nome } & \text { O/P Placer } \\ \text { Cape Nome } & \text { S/D - Recreation } \\ \text { Fairhaven } & \text { O/P Placer } \\ \text { Cape Nome } & \text { O/P Placer } \\ \text { Fairhaven } & \text { O/P Placer }\end{array}$

Tolovana S/D - Recreation

Fairbanks $\quad$ O/P Placer

Circle O/P Placer

Circle O/P Placer

Fortymile O/P Placer

Fortymile S/D - Recreation

Fortymile S/D - Recreation

Fortymile O/P Placer

Fortymile O/P Placer

Fortymile O/P Placer

Hot Springs O/P Placer

Fairbanks O/P Placer

Eagle S/D - Large

Fortymile O/P Placer

Fortymile O/P Placer

Delta River O/P Placer

Fairbanks O/P Placer

Fortymile S/D - Large

Chistochina O/P Placer

Bonnifield O/P Placer

Bonnifield O/P Placer

Valdez Creek O/P Placer

Circle O/P Placer

Fairbanks $\quad$ O/P Placer

Eagle O/P Placer

Hot Springs O/P Placer

Bonnifield O/P Placer

Eagle O/P Placer

Fortymile O/P Placer

Delta River O/P Placer

Fairbanks O/P Placer

Fairbanks O/P Placer

Fairbanks O/P Placer

Fairbanks $\quad$ O/P HR

Fairbanks O/P HR

Fortymile S/D - Large

Fairbanks O/P Placer

Circle O/P Placer

$\overline{\mathrm{a}} / \mathrm{P}=$ Open-pit; $\mathrm{H} / \mathrm{R}$ = Hard-rock; U/G = Underground; $\mathrm{S} / \mathrm{D}=$ Suction Dredge; Large - Greater than equal to 8” nozzle.

$\mathrm{S} / \mathrm{D}$ - Recreation = small suction dredge and recreational operations. Prepared from list of permitted operations; not all produced during the year. 


\begin{tabular}{|c|c|c|c|}
\hline Operator & Creek & District & Type $^{a}$ \\
\hline George Seuffert, Jr. & Chicken Creek, Mosquito Fork & Fortymile & O/P Placer \\
\hline George Seuffert, Jr. & Faith Creek & Fairbanks & O/P Placer \\
\hline Gerald Pitcher & Deadwood Creek & Circle & S/D - Recreation \\
\hline Gerald Standefer & Newman Creek & Bonnifield & O/P Placer \\
\hline Gold Adventures LLC & Boulder Creek & Hot Springs & O/P Placer \\
\hline Harold Mitchell & Mosquito Fork & Fortymile & O/P Placer \\
\hline Herning Exploration \& Mining & Palmer Creek & Fairbanks & S/D - Recreation \\
\hline Jackson Mining Company & Totatlanika River & Bonnifield & O/P Placer \\
\hline James Decker & Sheep Creek & Bonnifield & O/P Placer \\
\hline James Kimbro & Fortymile River & Fortymile & S/D - Large \\
\hline James Treesh & Cherry Creek & Fortymile & O/P Placer \\
\hline Jean Turner & Fortymile River & Fortymile & O/P Placer \\
\hline Jean Turner & Fox Creek & Fairbanks & O/P Placer \\
\hline Jeff Owen & Davis Creek & Fortymile & O/P Placer \\
\hline Jerry Gallagher & Slate Creek & Rampart & S/D - Recreation \\
\hline John Lindholm & Any Creek & Fairbanks & O/P Placer \\
\hline John McClain & Kokomo Creek & Fairbanks & O/P Placer \\
\hline John Schwartz & Our Creek & Fortymile & O/P Placer \\
\hline Judd Edgerton & Napoleon Creek & Fortymile & O/P Placer \\
\hline Keith Webster & Cherry Creek & Fortymile & O/P Placer \\
\hline Kelly Mining & North Fork Creek & Hot Springs & O/P Placer \\
\hline Kenneth Hanson & Faith Creek & Fairbanks & O/P Placer \\
\hline Kevin Bergman & Ester Creek & Fairbanks & O/P Placer \\
\hline Kinross Gold Corp. & Fort Knox Mine & Fairbanks & O/P HR \\
\hline KMM, Inc. & Hunter Creek & Rampart & O/P Placer \\
\hline L \& L Mining & Eagle Creek & Circle & O/P Placer \\
\hline Leo Regner & Lilliwig Creek & Fortymile & O/P Placer \\
\hline Linda Penfield & Slate Creek & Rampart & O/P Placer \\
\hline Mark Brooks & Mosquito Fork & Fortymile & S/D - Recreation \\
\hline Mammoth Mining & Porcupine Creek & Circle & O/P Placer \\
\hline Melvin Montgomery & Gilliland Creek & Fortymile & O/P Placer \\
\hline Melvin Montgomery & Jack Wade & Fortymile & O/P Placer \\
\hline Michael Mulligan & Skoogy Gulch & Fairbanks & O/P Placer \\
\hline Michael Patrick & Fortymile River & Fortymile & S/D - Large \\
\hline Miller Creek Mining Co. & Ketchum Creek & Circle & O/P Placer \\
\hline Olson Placers & Ketchum Creek & Circle & O/P Placer \\
\hline Paul \& Company & Porcupine Creek & Circle & O/P Placer \\
\hline Peter Johnson & Fortymile River & Fortymile & S/D - Large \\
\hline Polar Mining Inc. & Goldstream Creek & Fairbanks & O/P Placer \\
\hline R \& M Mining & Birch Creek & Circle & O/P Placer \\
\hline Raleigh Cline & Eagle Creek & Fortymile & O/P Placer \\
\hline Rampart Exploration LLC & American Creek & Hot Springs & O/P Placer \\
\hline Ray Wolf & Greenhorn Creek & Circle & O/P Placer \\
\hline Ray Wolf & Traverse Creek & Circle & O/P Placer \\
\hline Ray Wolf & Bottom Dollar Creek & Circle & O/P Placer \\
\hline Raymond Meder & Flume Creek & Fairbanks & O/P Placer \\
\hline Red Olson Mining & Deadwood Creek & Circle & O/P Placer \\
\hline Richard Farkas & Deadwood Creek & Circle & O/P Placer \\
\hline Richard Loud & Harrison Creek, North Fork Harrison Creek & Circle & O/P Placer \\
\hline Richard Ott & Omega Creek & Hot Springs & O/P Placer \\
\hline Richard Swenson & Doric Creek & Hot Springs & O/P Placer \\
\hline Richard Wilder & Little Boulder Creek & Hot Springs & O/P Placer \\
\hline Richardson Shield LLC & No Grub Creek & Fairbanks & O/P Placer \\
\hline Rob Keller & Thistle Creek & Bonnifield & O/P Placer \\
\hline Robert Hare & Gold Dust Creek & Circle & O/P Placer \\
\hline Robert Kirsch & Kal Creek & Fortymile & O/P Placer \\
\hline Ron Wrede & Switch Creek & Circle & O/P Placer \\
\hline
\end{tabular}

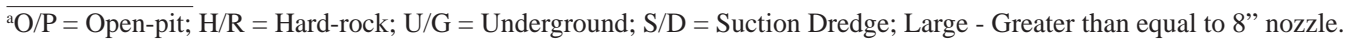

S/D - Recreation = small suction dredge and recreational operations. Prepared from list of permitted operations; not all produced during the year. 


\begin{tabular}{|c|c|c|c|}
\hline Operator & Creek & District & Type $^{\mathrm{a}}$ \\
\hline Ronald Tucker & Lillian Creek & Tolovana & O/P Placer \\
\hline RU Mining LLC & Olive Creek & Tolovana & O/P Placer \\
\hline Rudd Van Dyke & Fortymile River & Fortymile & S/D - Large \\
\hline Scott Thomas & Deadwood Creek & Circle & O/P Placer \\
\hline Schmidt Mining & Walker Fork & Fortymile & O/P Placer \\
\hline Sheldon Maier & Montana Creek & Fortymile & O/P Placer \\
\hline Sherlund Mining, LLC & Ketchum Creek & Circle & O/P Placer \\
\hline Silver Jim Stroer & Confederate Creek & Fortymile & S/D - Recreation \\
\hline Stephen Olson & Liberty Creek & Fortymile & O/P Placer \\
\hline Steve Holmes & Gold King Creek & Bonnifield & O/P Placer \\
\hline Steven Olson & Eagle Creek & Circle & O/P Placer \\
\hline Teck Pogo, Inc. & Pogo Mine & Goodpaster & U/G HR \\
\hline Terry Russell & Ready Money Creek & Hot Springs & O/P Placer \\
\hline Terry Russell & Trail Creek & Hot Springs & O/P Placer \\
\hline Theodore Payment & Fortymile River & Fortymile & O/P Placer \\
\hline Timothy Ruppert & Little Moose Creek & Bonnifield & S/D - Recreation \\
\hline Vernon Thurneau & Fortymile River & Fortymile & O/P Placer \\
\hline Wanda Severson & Willow Creek & Fortymile & S/D - Recreation \\
\hline Wesley Devore & North Fork Fortymile River & Fortymile & S/D - Recreation \\
\hline William Aldridge & Poker Creek & Fortymile & O/P Placer \\
\hline \multicolumn{4}{|c|}{ SOUTHCENTRAL REGION } \\
\hline Carl Wilbur & Yacko Creek & Nelchina & O/P Placer \\
\hline Daniel Hartman & Cache Creek & Yentna & S/D - Recreation \\
\hline Dennis Boyce & Busch Creek & Valdez Creek & O/P Placer \\
\hline Fred Wilkes & Bird Creek & Yentna & O/P Placer \\
\hline Gerald Anderson & Yacko Creek & Nelchina & O/P Placer \\
\hline Girdwood Mining Co. & Crow Creek & Anchorage & O/P Placer \\
\hline Gorden Bartel & Mills Creek & Yentna & O/P Placer \\
\hline Gordon Richmond & Buchia Creek & Valdez Creek & O/P Placer \\
\hline James Werner & Canyon Creek & Hope & S/D - Recreation \\
\hline John Deacon & Canyon Creek & Hope & S/D - Recreation \\
\hline John Werner & Cache Creek & Hope & S/D - Recreation \\
\hline Herman Mrak & Willow Creek, Grubstake Creek & Willow Creek & O/P Placer \\
\hline Kenneth Lee & Cache Creek & Yentna & O/P Placer \\
\hline Mark Richard & Caribou Creek & Willow Creek & O/P Placer \\
\hline Mike Spain & Homestake Creek, Grubstake Creek & Willow Creek & S/D - Recreation \\
\hline New Recovery Systems, Inc. & Alfred Creek & Willow Creek & O/P Placer \\
\hline Richard Peterson & Willow Creek & Nelchina & O/P Placer \\
\hline Sean Toohey & Crow Creek & Anchorage & S/D - Recreation \\
\hline Tom Bates & Long Creek & Yentna & S/D - Recreation \\
\hline Tom Sternberg & Quartz Creek & Hope & S/D - Recreation \\
\hline \multicolumn{4}{|c|}{ SOUTHWESTERN REGION } \\
\hline Ben Porterfield & Fish Creek & McGrath-McKinley & O/P HR \\
\hline Clark-Wiltz Mining & Ganes Creek & Innoko & O/P Placer \\
\hline Hanson Industries Inc. & Salmon River & Goodnews & O/P Placer \\
\hline Harry Faulkner & Ophir Creek & Aniak & O/P Placer \\
\hline L. E. Wyrick & Granite Creek & Aniak & O/P Placer \\
\hline Larry Wilmarth & George River & Aniak & S/D - Recreation \\
\hline Lyman Resources Alaska Inc. & Crooked Creek, Donlin Creek & Iditarod & O/P Placer \\
\hline Mark Matter & Marvel Creek & Aniak & O/P Placer \\
\hline Max Agoff & Prince Creek & Iditarod & O/P Placer \\
\hline Moore Creek Mining & Moore Creek & Innoko & O/P Placer \\
\hline NYAC Mining Company & N/A - Old Dredge Tailings & Aniak & O/P Placer \\
\hline NYAC Mining Company & Sahula Creek & Aniak & O/P Placer \\
\hline NYAC Mining Company & Shamrock Creek & Aniak & O/P Placer \\
\hline
\end{tabular}

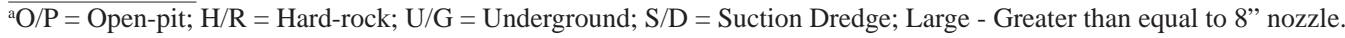

$\mathrm{S} / \mathrm{D}$ - Recreation = small suction dredge and recreational operations. Prepared from list of permitted operations; not all produced during the year. 


\begin{tabular}{|c|c|c|c|}
\hline Operator & Creek & District & Type $^{a}$ \\
\hline NYAC Mining Company & California Creek, Rock Creek & Aniak & O/P Placer \\
\hline Richard Busk & Syneeva Creek & Aniak & S/D - Recreation \\
\hline \multicolumn{4}{|c|}{ ALASKA PENINSULA } \\
\hline Alex Ameson & Beach sands & Kodiak & S/D - Recreation \\
\hline \multicolumn{4}{|c|}{ SOUTHEASTERN REGION } \\
\hline Chilkat Mining LLC & Porcupine Creek & Juneau & O/P Placer \\
\hline Earle Foster & Porcupine Creek & Juneau & O/P Placer \\
\hline John Schnabel & Porcupine Creek & Juneau & O/P Placer \\
\hline Kennecott Greens Creek & Greens Creek Mine & Admiralty & U/G HR \\
\hline Snow Lion II Ltd. Partnership & Porcupine Creek & Juneau & O/P Placer \\
\hline
\end{tabular}




\section{APPENDIX E \\ State and federal agencies and private interest groups involved in mineral development activities, 2007}

(The Alaska Miners Association Directory lists technical and professional consultants and companies available for work in Alaska. The report is published annually and is free to AMA members. The cost for non members is \$15 plus shipping and handling.)

\section{STATE OF ALASKA AGENCIES}

\section{OFFICE OF THE GOVERNOR}

Office of International Trade

550 West 7th Ave., Ste. 1700

Anchorage, AK 99501

(907) 269-7450

(907) 269-7461 (fax)

Function: Primary state office for promotion of exports.

Maintains overseas offices to increase Alaska's visibility in key markets.

\section{DEPARTMENT OF COMMERCE, COMMUNITY \& ECONOMIC DEVELOPMENT \\ State Office Building, 9th Fl. \\ P.O. Box 110801 \\ Juneau, AK 99811-0801 \\ http://www.commerce.state.ak.us \\ (907) 465-2500 \\ (907) 465-5442 (fax)}

Function: Promotes economic development in Alaska.

Office of Economic Development

550 W. 7th Ave., Ste. 1770

Anchorage, AK 99501

(907) 269-8112

(907) 269-8125 (fax)

Office of Mineral Development

211 Cushman St.

Fairbanks, AK 99701-4639

(907) 451-2738

(907) 451-2742(fax)

email: rich.hughes@alaska.gov

http://www.commerce.state.ak.us/oed/minerals/mining.htm

Function: Primary state government advocacy agency for economic growth. Researches and publishes economic data on Alaska's mining industry. Attracts capital investment by advertising Alaska's resource potential. Provides research staff aid for the Alaska Minerals Commission. In cooperation with the Office of International Trade, OED also encourages the development of new markets for Alaska resources, increases the visibility of Alaska and its products in the international marketplace, and makes referrals and provides technical assistance to those interested in developing export markets for Alaska-produced or value-added goods and services.

Alaska Industrial Development \& Export Authority (AIDEA) 813 W. Northern Lights Blvd.

Anchorage, AK 99503

(907) 269-3000

(907) 269-3044 (fax)

http://www.aidea.org

Function: AIDEA provides capital to finance economic growth throughout Alaska-from multi-million-dollar mining projects

to small, family-owned businesses; from urban centers to small towns and rural villages. Regardless of project size, location, or business type, all AIDEA-financed projects must enhance the state's economy and provide or maintain jobs for Alaskans. AIDEA's financing assistance programs- the Credit Program and the Development Finance Program-have played an important role in Alaska's mineral development. The Credit Program includes the Loan Participation, Business and Export Assistance loan guarantee, and the Tax-Exempt Revenue Bond programs. AIDEA's Development Finance Program allows AIDEA to develop, own, and operate facilities within Alaska such as roads, ports, and utilities which are essential to the economic well-being of an area; are financially feasible; and are supported by the community in which they are located.

\section{P.O. Box 111800 \\ Juneau, AK 99811-1800 \\ (907) 465-5070 (fax) \\ (907) 465-5065 Commissioner's Office \\ http://www.dec.state.ak.us}

DEPARTMENT OF ENVIRONMENTAL CONSERVATION

Function: Issues permits for activities (including mining) that affect air or water quality or involve land disposal of wastes. Sets air- and water-quality standards. Inspects, monitors, and enforces environmental quality statutes, regulations, and permits. Reviews all federal permits.

Department of Environmental Conservation Anchorage Office

555 Cordova St.

Anchorage, AK 99501-2617

(907) 269-7500

(907) 269-7600 (fax)

1-800-510-2332 (inside Alaska only)

http://www.dec.state.ak.us

Department of Environmental Conservation

Fairbanks Office

610 University Ave.

Fairbanks, AK 99709-3643

(907) 451-2100

(907) 451-5120 (fax)

(907) 451-2184 TTY

http://www.dec.state.ak.us

\section{DEPARTMENT OF FISH AND GAME}

P.O. Box 115526

Juneau, AK 99811-5526

(907) 465-4100

(907) 465-2332

http://www.state.ak.us/adfg

Division of Habitat

Headquarters

P.O. Box 115526

Juneau, AK 99811-5526

(907) 465-1852

(907) 465-2066 (fax)

http://www.habitat.adfg.alaska.gov 
Function: The Division of Habitat fulfills specific statutory responsibilities for (1) protecting freshwater and anadromous fish habitat under the Anadromous Fish Act (AS 41.14.870) and (2) providing free passage of anadromous and resident fish in fresh waterbodies (AS 41.14.840). It requires prior written authorizations for any work affecting the free movement of fish, for any use or activity that may affect designated anadromous fish waters, and for any disturbance-producing or habitat-altering activity.

Operations Manager \& Fairbanks Area Office

1300 College Rd.

Fairbanks, AK 99701-1551

(907) 459-7289

(907) 459-7303 (fax)

Anchorage Area Office

333 Raspberry Rd.

Anchorage, AK 99518-1565

(907) 267-2342

(907) 267-2499 (fax)

Juneau Office

P.O. Box 110024

Juneau, AK 99811-0024

(907) 465-4105

(907) 465-4759 (fax)

Kenai Area Office

514 Funny River Rd.

Soldotna, AK 99669-8255

(907) 260-4882 ext. 222

(907) 260-5992 (fax)

Mat-Su Area Office

1800 Glenn Highway, Ste. 12

Palmer, AK 99645-6736

(907) 761-3855

(907) 745-7369 (fax)

Petersburg Area Office

P.O. Box 667

Petersburg, AK 99833-0667

(907) 772-5224

(907) 772-9336 (fax)

Prince of Wales Area Office

P.O. Box 668

Craig, AK 99921-0668

(907) 826-2560

(907) 826-2562 (fax)

Division of Forestry

550 W. 7th Ave., Ste. 1450

Anchorage, AK 99501-3566

(907) 269-8463

http://www.dnr.state.ak.us/forestry

Function: Establishes guidelines to manage mining in state forests.

Northern Region Office

3700 Airport Way

Fairbanks, AK 99709-4699

(907) 451-2660
Coastal Region Office

101 Airport Rd.

Palmer, AK 99645

(907) 761-6200

\section{DEPARTMENT OF NATURAL RESOURCES}

Office of the Commissioner

550 W. 7th Ave., Ste. 1400

Anchorage, AK 99501

(907) 269-8431

http://www.dnr.state.ak.us

Alaska Coastal Management Program

302 Gold St., Ste. 202

Juneau, AK 99801

(907) 465-3562

(907) 465-3075 (fax)

Function: Conducts coordinated State reviews of mining projects within the coastal zone, while coordinating with Federal mining permitting agencies. Assists applicants in shaping mining projects to be consistent with the ACMP. Coordinates State response to Federal development activities and permitting actions (including proposed regulations) that affect Alaska's mining industry.

Southcentral Regional Office

550 W. 7th Ave., Ste. 1660

Anchorage, AK 99501-3568

(907) 269-7470

(907) 269-3981 (fax)

\author{
Alaska Mental Health Trust Land Office \\ 718 L St., Ste. 202 \\ Anchorage, AK 99501 \\ (907) 269-8658 \\ (907) 269-8905 (fax) \\ http://www.mhtrustland.org
}

Function: The Trust Land Office (TLO) manages the approximately 1 million acres of land that are included in the Alaska Mental Health Land Trust, which was created by Congress in 1956. Lands in the Trust are located throughout the state and are used to generate revenues to meet the expenses of mental health programs in Alaska. Management activities include all aspects of land use and resource development, including mineral and oil and gas leasing, exploration, and development; material sales (including gravel, sand, and rock); timber sales; surface leasing; land sales; and issuance of easements across Trust land.

Division of Geological \& Geophysical Surveys

3354 College Rd.

Fairbanks, AK 99709-3707

(907) 451-5010

(907) 451-5050 (fax)

email: dggs@dnr.state.ak.us

http://wwwdggs.dnr.state.ak.us

Function: Conducts geological and geophysical surveys to determine the potential of Alaska land for production of metal, mineral, fuel, and energy resources; locations and supplies of construction materials; potential geologic hazards to buildings, roads, bridges, and other installations and structures; and other surveys and investigations as will advance knowledge of the geology of Alaska (from AS 41.08.020). Publishes a variety of reports and maintains a web site that contain the results of these investigations. Advises the public and government agencies on geologic issues. Maintains a library of geologic bulletins, reports, and periodicals. Maintains a Geologic Materials Center storage facility at Eagle River. 
Geologic Materials Center

P.O. Box 772805

Eagle River, AK 99577-2805

(907) 696-0079

(907) 696-0078 (fax)

John_Reeder@dnr.state.ak.us

Division of Mining, Land \& Water

550 W. 7th Ave., Ste. 1070

Anchorage, AK 99501

(907) 269-8600

(907) 269-8904 (fax)

http://www.dnr.state.ak.us/mlw

\section{A. Mining}

Function: Principal agency for management of mining and reclamation on state land in Alaska. Maintains offices in Anchorage and Fairbanks. Issues property rights to leasable minerals; manages locatable mineral filings. Also issues millsite leases and permits for hard rock and placer mining activity. Maintains records of mineral locations, permits and leases. Provides technical, legal, and land-status information. Administers the Alaska Surface Mining Control and Reclamation Act (ASMCRA), which includes permitting and inspection of coal mining activity and reclamation of abandoned mines.

\section{B. Land}

Function: Manages surface estate and resources, including materials (gravel, sand, and rock). Handles statewide and regional land-use planning. Issues leases, material-sale contracts, landuse permits, and easements for temporary use of State land and access roads. Administers land sales program.

\section{Water Management}

Function: Manages water resources of the State; issues waterrights permits and certificates; responsible for safety of all dams in Alaska.

\section{Mining Information:}

Anchorage (907) 269-8642

Fairbanks (907) 451-2793

All other Land \& Water Information:

Northern Regional Office

3700 Airport Way

Fairbanks, AK 99709-4699

(907) 451-2740

(907) 451-2751 (fax)

Southcentral Regional Office

550 W. 7th Ave., Ste. 900C

Anchorage, AK 99501

(907) 269-8503

(907) 269-8913 (fax)

Southeast Regional Office

400 Willoughby Ave., Ste. 400

Juneau, AK 99801-1724

(907) 465-3400

(907) 586-2954 (fax)

E-mail: sero@dnr.state.ak.us

\section{Division of Parks and Outdoor Recreation}

550 W. 7th Ave., Ste. 1310

Anchorage, AK 99501-3565

(907) 269-8700

Function: Manages approximately 3,000,000 acres of state park lands primarily for recreational uses, preservation of scenic val- ues, and watershed. Responsible for overseeing mining access, recreational mining activity, and valid mining-claim holdings within state park lands. The Office of History and Archaeology reviews mining permit applications on all lands within the state for impacts to historic resources.

Northern Regional Office

3700 Airport Way

Fairbanks, AK 99709-4699

(907) 451-2695

Southeast Area Office

400 Willoughby Ave., 5th Fl.

P.O. Box 111071

Juneau, AK 99811-1071

(907) 465-4563

(907 586-3113 (fax)

Office of History and Archaeology

550 W. 7th Ave., Ste. 1310

Anchorage, AK 99501-3565

(907) 269-8721

(907) 269-8908 (fax)

email: stefaniel@dnr.state.ak.us

http://www/parks/oha

\section{DEPARTMENT OF PUBLIC SAFETY}

Public Safety Headquarters

Office of the Commissioner

5700 East Tudor Rd.

Anchorage, AK 99507-1225

(907) 269-5086

(907) 269-4543 (fax)

http://www.dps.state.ak.us

\section{Alaska Bureau of Wildlife Enforcement}

5700 East Tudor Rd.

Anchorage, AK 99507-1225

(907) 269-5509

Function: Enforces state laws, in particular AS Title 16. Protects Alaska's fish and wildlife resources through enforcement of laws and regulations governing use of natural resources within Alaska. These laws are in Alaska Statutes 8, 16, 46, and Alaska Administrative Codes 5, 12, and 20.

\section{DEPARTMENT OF REVENUE}

State Office Bldg.

11th Fl., Entrance A

P.O. Box 110400 (mailing)

Juneau, AK 99811-0400

(907) 465-2300

http://www.revenue.state.ak.us

\section{Tax Division}

550 W 7th Ave., Ste. 500

Anchorage, AK 99501-3555

(907) 269-6620

(907) 269-6444 (fax)

email: dor.tax.mining@alaska.gov

http://www.tax.alaska.gov/

Function: Issues licenses for sand and gravel operations. Administers mining-license tax based on net income, including royalties. New mining operations-except sand and gravel mining - can apply for and receive certificates of tax exemption for the first 31/2 years of operation. (Tax returns must be filed annually.) 


\section{UNIVERSITY OF ALASKA}

College of Natural Science and Mathematics

Department of Geology \& Geophysics

P.O. Box 755780

Natural Sciences Building, Room 308

University of Alaska Fairbanks

Fairbanks, AK 99775-5780

(907) 474-7565

(907) 474-5163 (fax)

email: geology@.uaf.edu

http://www.uaf.edu/geology

Function: Provides undergraduate and graduate education in geology and geophysics and conducts basic and applied research in geologic sciences. For undergraduate studies, the department offers a B.A. program in Earth Science and a B.S. program in Geology (with emphasis options in general geology, economic geology, and petroleum geology). For graduate studies, the department offers M.S. and Ph.D. programs in Geology and Geophysics, with concentrations in: General geology; economic geology; petroleum geology; Quaternary geology; remote sensing; volcanology; solid-earth geophysics; and snow, ice, and permafrost geophysics.

College of Engineering and Mines

P.O. Box 755960

Duckering Building, Room 357

University of Alaska Fairbanks

Fairbanks, AK 99775-5960

(907) 474-7730

(907) 474-6994 (fax)

email: fycem@uaf.edu

http://www.uaf.edu/cem

Function: Provides undergraduate and graduate education programs in geological engineering, mining engineering, mineral preparation engineering, civil engineering, mechanical engineering, and electrical engineering. Through research programs, conducts laboratory and field studies to promote mineral and energy development.

Mineral Industry Research Laboratory (MIRL)

College of Engineering and Mines

P.O. Box 757240

Duckering Building, Room 403

University of Alaska Fairbanks

Fairbanks, AK 99775-7240

(907) 474-6746

(907) 474-5400 (fax)

email: ffdew1@uaf.edu

Function: Conducts applied and basic research in exploration, development, and utilization of Alaska's mineral and coal resources with emphasis on coal characterization, coal utilization, coal upgrading, coal preparation, mineral beneficiation, fine gold recovery, hydrometallurgy, and environmental concerns. Publishes reports on research results and provides general information and assistance to the mineral industry.

Dept. of Mining and Geological Engineering

College of Engineering and Mines

P.O. Box 755800

Duckering Building, Room 301

University of Alaska Fairbanks

Fairbanks, AK 99775-5800

(907) 474-7388

(907) 474-6635 (fax)

email: fyminge@uaf.edu

http://www.uaf.edu/cem
Function: Provides undergraduate and graduate education programs in geological engineering, mining engineering, and mineral preparation engineering. Through research programs, conducts laboratory and field studies to promote mineral and energy development.

Mining and Petroleum Training Service

162 College Rd.

University of Alaska

Soldotna, AK 99669

(907) 262-2788

(907) 262-2812 (fax)

email:mapts@alaska.net

www.mapts.alaska.edu

Function: Provides direct training and assistance to mine operators, service and support companies, and governmental agencies in mine safety and health, mining extension, vocational mine training, and technical transfer. Specialized training services in hazardous materials, first aid and CPR, and industrial hygiene. Professional safety education and consulting are available on demand.

\section{FEDERAL AGENCIES}

\section{U.S. DEPARTMENT OF THE INTERIOR}

Office of the Secretary

1689 C St., Ste. 100

Anchorage, AK 99501-5151

(907) 271-5485

(907) 271-4102

Function: Coordinates the Department of the Interior's policy and stewardship with DOI bureaus for the management of more than 200 million acres of public land in Alaska.

\section{U.S. Bureau of Land Management}

Alaska State Office

Division of Lands, Minerals, and Resources

222 West 7th Ave., Ste. 13

Anchorage, AK 99513-7599

Public Information Center (907) 271-5960

Northern Field Office (907) 474-2252

Public Information Center

http://www.ak.blm.gov/

Energy Branch (907) 271-5049

Solid Minerals Branch (907) 271-5049

\section{Division Functions:}

$B L M$ is the surface manager of federal public lands (except national parks, wildlife refuges, national monuments, national forests, and military withdrawals). The Division is responsible for developing and coordinating statewide and regional program management policies and strategies related to federal onshore energy and non-energy leasable minerals, mineral assessments, and locatable minerals. It provides technical assistance and coordinates activities relating to ANILCA 1010 mineral assessments. The Division provides the basis for economic analysis relating to energy and mineral development in the state. It also provides leadership and technical assistance on abandoned mine lands inventories and impacts on public lands.

\section{Energy Branch Functions:}

The Branch is responsible for the federal onshore mineral leasing programs and functions; including oil and gas, geothermal resources, coal, and other energy and non-energy minerals. The 
Branch prepares and conducts oil and gas lease sales and is responsible for preparing pre- and post-lease sale fair market value evaluations for National Petroleum Reserve-Alaska leasing, and issuing leases; adjudicates oil and gas leases, transfers, and bonds; approves oil and gas industry operations for federal onshore oil and gas leases; protects federal lands from drainage of oil and gas resources, and inspects industry operations for compliance; and coordinates with other federal surface management agencies for the leasing and monitoring of minerals operations under their jurisdictions.

\section{Solid Minerals Branch Functions:}

The Branch maintains mining claim and mineral patent case files and electronic public minerals records related to those files. It adjudicates federal mining claim recordation filings, annual assessment affidavits, and timely payment of annual claim holding fees. It also adjudicates mineral survey and patent applications, and serves contest complaints for all federal lands in Alaska.

Anchorage Field Office

6881 Abbott Loop Rd.

Anchorage, AK 99507-2599

(907) 267-1246

(907) 267-1267 (fax)

Glennallen Field Office

P.O. Box 147

Glennallen, AK 99588

(907) 822-3217

(907) 822-3120 (fax)

http://www.glennallen.ak.blm.gov

Kotzebue Field Station

P.O. Box 1049

Kotzebue, AK 99752-1049

(907) 442-3430

(907) 442-2720 (fax)

Nome Field Station

P.O. Box 925

Nome, AK 99762-0925

(907) 443-2177

(907) 443-3611 (fax)

Northern Field Office

1150 University Ave.

Fairbanks, AK 99709-3899

(907) 474-2200

(907) 474-2251 Public Room

(907) 474-2282 (fax)

1-800-437-7021

Tok Field Station

P.O. Box 309

Tok, AK 99780

(907) 883-5121

(907) 883-5123 (fax)

\section{U.S. Fish and Wildlife Service}

Region 7 Office

Mail Stop 361

1011 East Tudor Rd.

Anchorage, AK 99503

(907) 786-3542

http://alaska.fws.gov/

Function: Administers the federal public lands in national wildlife refuges, issues special-use permits for activities on refuges, reviews permits and applications for various mining activities on all private and public lands and waters, and provides information to regulatory agencies on fish and wildlife and their habitat. Makes recommendations to regulatory agencies to mitigate adverse environmental impacts.

U.S. Fish and Wildlife Service

Fairbanks Fish and Wildlife Field Office

101 12th Ave., Room 110

Fairbanks, AK 99701

(907) 456-0203

(907) 456-0208 (fax)

U.S. Fish and Wildlife Service

Juneau Fish and Wildlife Field Office

3000 Vintage Blvd., Ste. 201

Juneau, AK 99801-7100

(907) 780-1160

(907) 586- 7154 (fax)

U.S. Fish and Wildlife Service

Anchorage Fish and Wildlife Field Office

605 West 4th Ave., Rm. G-61

Anchorage, AK 99501

(907) 271-2888

(907) 271-2786 (fax)

\section{U.S. Geological Survey}

Alaska Science Center

Geological Science Office

4200 University Dr.

Anchorage, AK 99508-4667

(907) 786-7479

The mission of the USGS Alaska Science Center (ASC) is to provide scientific leadership and accurate, objective, and timely data, information, and research findings about the earth and its flora and fauna to Federal and State resource managers and policy makers, local government, and the public to support sound decision making regarding natural resources, natural hazards, and ecosystems in Alaska and circumpolar regions.

Geologic Discipline programs in the ASC are based on insightful monitoring, assessments, and research activities that address natural hazards, earth resources, and geologic processes. The Geologic Discipline provides comprehensive, high quality, and timely scientific information to decision makers at Federal, State, and local government levels, as well as the private sector. The Minerals Program investigates and reports on the occurrence, quality, quantity, and environmental characteristics of mineral resources in Alaska, the processes that create and modify them, models for assessing mineral endowment, and the potential impacts of mineral development.

U.S. Geological Survey

Alaska Science Center

National Geospatial Program Office

4230 University Dr., Ste. 101

Anchorage, AK 99508-4664

(907) 786-7011

Function: Publishes and distributes all available topographic maps of Alaska, digital products, and aerial photography.

National Park Service

Alaska Regional Office

Natural Resources Science Team

240 W. 5th Ave. 
Anchorage, AK 99501

(907) 644-3571

(907) 644-3809 (fax)

Function: Administers lands within the national park system in Alaska. Manages oil and gas operations and pre-existing valid mining claims in parklands through plans of operation under Mining in Parks Act, National Park Service regulations, and other applicable federal and state laws and regulations.

\section{U.S. DEPARTMENT OF LABOR}

Mine Safety and Health Administration

Physical Address:

222 W. 8th Ave A-35

Anchorage, AK 99513

(907) 271-1250

(907) 271-1252 (fax)

email: bowen.ayers@dol.gov

\section{Mailing Address:}

Anchorage Federal Building

US Courthouse - Rm. A-35

222 West 7th Ave., Box 30

Anchorage, AK 99513

(907) 271-1250

(907) 271-1252 (fax)

email: bowen.ayers@dol.gov

Function: Administers health and safety standards to protect the health and safety of metal, nonmetal, and coal miners. Cooperates with the State to develop health and safety programs and develops training programs to help prevent mine accidents and occupationally caused diseases. Under agreement with the Coal Mine Safety and Health Office, the MSHA metal/nonmetal section has assumed responsibility for enforcement and training activities at coal mines in Alaska.

Mine Safety and Health Administration

Coal Mine Safety and Health, District 9

P.O. Box 25367

Denver, CO 80225

(303) 231-5458

(303) 231-5553 (fax)

http://www.msha.gov

Function: Administers health and safety standards according to the Code of Federal Regulations to protect the health and safety of coal miners; requires that each operator of a coal mine comply with these standards. Cooperates with the State to develop health and safety programs and develops training programs to help prevent coal or other mine accidents and occupationally caused diseases in the industry.

\section{U.S. DEPARTMENT OF AGRICULTURE}

Forest Service

Regional Office, R.L.M.

Attn: John Kato

Assistant Director for Minerals and Geology Programs

P.O. Box 21628

Juneau, AK 99802-1628

(907) 586-7869

(907) 586-7866 (fax)

email: jkato@fs.fed.us

http://www.fs.fed.us/

http://www.fs.fed.us/r10earth/

Function: With the Bureau of Land Management, provides joint administration of general mining laws on national forest system lands. Cooperates with Department of Interior agencies in the review and issuance of mineral leases. Issues permits for disposal of sand, gravel, and stone.

\author{
U.S. ENVIRONMENTAL PROTECTION AGENCY \\ Region 10 Regional Office \\ 1200 6th Ave., MS OW-130 \\ Seattle, WA 98101 \\ (206) $553-1200$ \\ (206) 553-1746 (NPDES permits) \\ http://www.epa.gov/r10earth/
}

Function: Issues National Pollutant Discharge Elimination System (NPDES) permits under the Clean Water Act to regulate effluent discharges. Implements a compliance enforcement program. Maintains regulatory and review authority over wetland and NEPA/EIS-related issues.

Alaska Operations Office

222 West 7th Ave., Rm. 537

222 W. 7th Ave., Box 19 (mailing)

Anchorage, AK 99513-7588

(907) 271-5083

Alaska Operations Office

709 W 9th St., Rm. 223A

Box 20370 (mailing)

Juneau, AK 99802-0370

(907) 586-7619

\section{U.S. DEPARTMENT OF THE ARMY}

Corps of Engineers

Regulatory Division

2204 3rd St.

P.O. Box 6898

Elmendorf Air Force Base, AK 99506-0898

(907) 753-2712

(907) $753-5567$ (fax)

(800) 478-2712 (in Alaska only)

http://www.poa.usace.army.mil/reg

Function: Regulates structures or work in navigable waters of the U.S. and discharge of dredged or fill material into U.S. waters, including wetlands. Under Section 404 of the Clean Water Act, the Corps of Engineers issues dredge and fill permits for certain mining activities in waters of the United States. Examples of regulated mining activities include construction of berms, dikes, diversions, ponds, overburden stripping, stockpiling, and reclamation activities.

\section{COOPERATIVE STATE-FEDERAL AGENCIES}

Alaska Public Lands Information Center

101 Dunkel St., Ste 110

Fairbanks, AK 99701

(907) 459-3730

(907) 459-3729 (fax)

Function: Clearinghouse for general information on outdoor recreation in Alaska. Information sources include U.S. Forest Service, U.S. Fish and Wildlife Service, U.S. Bureau of Land Management, U.S. Geological Survey, National Park Service, Alaska Departments of Natural Resources, Fish and Game, and Community and Economic Development.

\section{BOARDS AND COMMISSIONS}

Alaska Minerals Commission

Irene Anderson, Chair

c/o Bering Straits Native Corp.

P.O. Box 1008 
Nome, AK 99762

(907) 443-5252

(907) 443-4317

(907) 443-2985 (fax)

email: irene@beringstraits.com

Function: The Minerals Commission was created by the Alaska State Legislature in 1986 to make recommendations to the Governor and the Legislature on ways to mitigate constraints on the development of minerals in Alaska. The Commission has published annual reports since 1987.

\section{CHAMBERS OF COMMERCE}

Alaska State Chamber of Commerce

217 Second St., Ste. 201

Juneau, AK 99801

(907) 586-2323

(907) 463-5515 (fax)

email: info@alaskachamber.com

http://www.alaskachamber.com

Function: The State Chamber of Commerce researches and formulates positions on Alaskan resource development. Recommendations for consideration are submitted to the State Chamber of Commerce board of directors.

Anchorage Chamber of Commerce 1016 W. 6th Ave., Ste. 303

Anchorage, AK 99501

(907) 272-2401

email: info@anchoragechamber.org

http://www.anchoragechamber.org

Function: To be effective as a business leader by supporting and focusing its broad-based membership in their efforts to grow Anchorage into a premier American city.

Greater Fairbanks Chamber of

\section{Commerce}

100 Cushman St., Ste. 102

Fairbanks, AK 99701

(907) 452-1105

(907) 456-6968 (fax)

email: info@fairbankschamber.org

http://www.fairbankschamber.org

Juneau Chamber of Commerce

3100 Channel Dr., Ste. 300

Juneau, AK 99801

(907) 463-3488

(907) 463-3489 (fax)

email: juneauchamber@gci.net

http://www.juneauchamber.org

\section{PUBLIC INTEREST GROUPS AND ASSOCIATIONS}

Alaska Miners Association Inc.

Statewide Office

Steven C. Borell, P.E., Executive Director

3305 Arctic Blvd., Ste. 105

Anchorage, AK 99503

(907) 563-9229

(907) 563-9225 (fax)

email: ama@alaskaminers.org

http://www.alaskaminers.org

\section{AMA BRANCHES}

Anchorage Juneau

Denali Kenai

Fairbanks Nome

Please contact AMA for current contacts

Alaskans for Responsible Mining

810 N St.

Anchorage, AK 99501

(907) 277-0005

(907) 277-0990 (fax)

email: vanessa@reformakmines.org

http://www.reformakmines.org

American Institute of

Professional Geologists

1400 W. 122nd Ave., Ste. 250

Westminster, CO 80234

(303) 412-6205

(303) 253-9220 (fax)

email: aipg@aipg.org

http://www.aipg.org

Earthjustice

325 Fourth St.

Juneau, AK 99801

(907) 586-2751

(907) 463-5891 (fax)

email: eajusak@earthjustice.org

http://www.earthjustice.org

National Wildlife Federation

750 W. Second Ave., Ste. 200

Anchorage, AK 99501

(907) 339-3900

(907) 339-3980 (fax)

Northern Alaska Environmental Center

830 College Rd.

Fairbanks, AK 99701-1535

(907) 452-5021

(907) 452-3100 (fax)

email: info@northern.org

http://www.northern.org

Northwest Mining Association

10 North Post St., Ste. 220

Spokane, WA 99201

(509) 624-1158

(509) 623-1241 (fax)

email: nwma_info@nwma.org

http://www.nwma.org
Resource Development

Council for Alaska, Inc.

121 W. Fireweed Ln., Ste. 250

Anchorage, AK 99503

(907) 276-0700

(907) 276-3887 (fax)

email: Resources@akrdc.org

http://www.akrdc.org

Society for Mining, Metallurgy, and

Exploration Inc.

8307 Shaffer Parkway

Littleton, CO 80127

(303) 973-9550

(303) 973-3845 (fax)

email: sme@smenet.org

http://www.smenet.org

Southeast Alaska Conservation Council

(SEACC)

419 6th St., Ste. 200

Juneau, AK 99801

(907) 586-6942

(907) 463-3312 (fax)

email: info@seacc.org

http://www.seacc.org

Trustees for Alaska

1026 W. 4th Ave., \# 201

Anchorage, AK 99501-1980

(907) 276-4244

email: ecolaw@trustees.org

http://www.trustees.org

\section{ORGANIZED MINING DISTRICTS}

Circle Mining District

P.O. Box 30181

Central, AK 99730-0181

(907) 520-5419 (message)

Fairbanks Mining District

105 Dunbar

Fairbanks, AK 99701

(907) 456-7642

Haines Mining District

P.O. Box 149

Haines, AK 99827

(907) 766-2821

Iditarod Mining District

John A. Miscovich

1320 K St.

Anchorage, AK 99501-4327

Yentna Mining District

Carol Young

P.O. Box 211

Talkeetna, AK 99676

(907) 733-2351 


\section{MINERAL EDUCATION \\ PROGRAMS}

ALASKA MINERAL AND ENERGY
RESOURCE EDUCATION FUND
(AMEREF)
4141 B Street, Suite 402
Anchorage, AK 99503
(907) 276-5487
(907) 276-5488 (fax)
email: kits@ameref.org
http://www.ameref.org
Function: A 501c(3) educational non-profit
$\quad$ whose mission is to provide Alaska's
$\quad$ students with the knowledge to make
$\quad$ informed decisions relating to mineral,
$\quad$ energy, and forest resources.
NATIVE REGIONAL
CORPORATIONS

\section{AHTNA INC.}

Kathryn Martin

VP Land and Resources

P.O. Box 649

Glennallen, AK 99588-0649

(907) 822-3476

(907) 822-3495 (fax)

email: kmartin@ahtna-inc.com

http://www.ahtna-inc.com/

Anchorage Office

406 W. Fireweed, Ste. 201

Anchorage, AK 99503

(907) 868-8202

(907) 868-8284 (fax)

email: brebne@ahtna-inc.com

http://www.ahtna-inc.com/

THE ALEUT CORP.

4000 Old Seward Hwy., Ste. 300

Anchorage, AK 99503-6087

(907) 561-4300

(907) 563-4328 (fax)

email: MSmith@aleutcorp.com

http://www.aleutcorp.com

ARCTIC SLOPE REGIONAL CORP.

P.O. Box 129

Barrow, AK 99723-0129

(907) 852-8633

(907) 852-5733 (fax)

http://www.asrc.com/

Anchorage Office

3900 C St., Ste. 801

Anchorage, AK 99503-5963

(907) 339-6000

(907) 339-6028 (fax)
BERING STRAITS NATIVE CORP.

Irene Anderson

Land Manager

P.O. Box 1008

Nome, AK 99762-1008

(907) 443-4317

(907) 443-2985 (fax)

email: irene@beringstraits.com

http://www.beringstraits.com/

Anchorage Office

Matt Ganley

4600 DeBarr Rd., Ste 200

Anchorage, AK 99508-3126

(907) 344-7212

(907) 563-2742 (fax)

email: matt@beringstraits.com

BRISTOL BAY NATIVE CORP.

111 West 16th Ave., Ste. 400

Anchorage, AK 99501-5109

(907) 278-3602

(907) 276-3924 (fax)

http://www.bbnc.net

\section{CALISTA CORP.}

301 Calista Court, Ste. A

Anchorage, AK 99518-3028

(907) 279-5516

(907) 272-5060 (fax)

http://www.calistacorp.com/

CHUGACH ALASKA CORP.

3800 Centerpoint Dr.

Anchorage, AK 99503-4196

(907) 563-8866

(907) 261-0373 (fax)

email: rrogers@chugach-ak.com

http://www.chugach-ak.com/

\section{COOK INLET REGION INC.}

and its subsidary North Pacific

Mining Corporation

2525 C St., Ste. 500

Anchorage, AK 99503

(907) 274-8638

(907) 263-5190 (fax)

email: kcunningham@ciri.com

http://www.ciri.com/

\section{DOYON LTD.}

1 Doyon Place, Ste. 300

Fairbanks, AK 99701-2941

(907) 459-2030

(907) 459-2062 (fax)

email: lands@doyon.com

http://www.doyon.com
KONIAG INC.

104 Center Ave., Ste. 205

Kodiak, AK 99615

(907) 4862530

(907) 486-3325 (fax)

http://www.koniag.com/

NANA REGIONAL CORP.

P.O. Box 49

Kotzebue, AK 99752

(907) 442-3301

(907) 442-2866 (fax)

http://www.nana.com

Anchorage Office

Nana Development Corp.

1001 E. Benson Blvd.

Anchorage, AK 99508

(907) 265-4100

(907) 265-4311 (fax)

SEALASKA CORP.

One Sealaska Plaza, Ste. 400

Juneau, AK 99801

(907) 586-1512

(907) 463-3897 (fax)

http://www.sealaska.com/ 


\section{APPENDIX F Alaska Mining Websites}

\section{Mining and Exploration Companies}

Alaska Earth Sciences Inc.

Alix Resources Corp.

Altair Ventures Inc.

Anchorage Sand and Gravel Co. Inc.

Andover Ventures Inc.

Anglo American plc

Avalon Development Corp.

Barrick Gold Corp.

BHP Billiton Ltd.

Bravo Venture Group Inc.

Browns Hill Quarry

Century Mining Corp.

Chuitna Coal Project

Clark-Wiltz Mining

Coeur d'Alene Mines Corp. (Coeur Alaska Inc.)

Constantine Metal Resources Inc.

Copper Ridge Explorations Inc.

Freegold Ventures Ltd.

Full Metal Minerals Ltd.

Geocom Resources Inc.

Geoinformatics Exploration Inc

Gold Crest Mines Inc.

Grayd Resource Corp.

Great Basin Gold Ltd.

Great Northwest Inc.

Greens Creek Mining Co.

Hecla Mining Co.

Hemis Corp.

Hidefield Gold Plc.

International Tower Hill Mines Ltd. (Talon Gold (US) LLC)

Kennecott Minerals Co.

Kinross Gold Corp. (Fairbanks Gold Mining Inc.)

Lafarge North America Inc.

Liberty Star Gold Corp.

Linux Gold Corp.

Little Squaw Gold Mining Co.

Max Resource Corp.

Metallica Resources Inc.

Midas Resources Ltd.

Moore Creek Mining LLC

Niblack Mining Corp.

Northern Associates Inc.

Northern Dynasty Minerals Ltd.

NovaGold Resources Inc.

Pacific North West Capital Corp.

Paradise Valley Inc.

Pure Nickel Inc.

Quaterra Resources Inc.

Rimfire Minerals Corp.

Rio Tinto Ltd.

Rubicon Minerals Corp.

Santoy Resources Ltd.

Select Resources Corp. (Tri-Valley Corp.) http://www.aes.alaska.com

http://www.alixresources.com/

http://www.altairventuresinc.com/

http://www.anchsand.com

http://www.andoverventures.com/

http://www.angloamerican.co.uk/

http://www.avalonalaska.com

http://www.barrick.com/

http://www.bhpbilliton.com/

http://www.bravoventuregroup.com/en/index.

php?page =home

http://bricecompanies.com/quarry/quarry.html

http://www.centurymining.com

http://www.chuitnaseis.com/default.htm

http://www.clark-wiltz.com/

http://www.coeur.com

http://www.constantinemetals.com/

http://www.copper-ridge.com

http://www.freegoldventures.com

http://www.fullmetalminerals.com

http://www.geocom-resources.com

http://www.geoinformex.com

http://www.goldcrestminesinc.com/

http://www.grayd.com

http://www.greatbasingold.com/

http://www.grtnw.com/

http://www.greenscreek.com/

http://www.hecla-mining.com

http://www.hemiscorporation.com/

http://www.hidefield.co.uk/s/Home.asp

http://www.ithmines.com/s/home.asp

http://www.kennecottminerals.com

http://www.kinross.com

http://www.lafargenorthamerica.com/wps/portal/

http://www.libertystargold.com

http://www.linuxgoldcorp.com

http://www.littlesquawgold.com

http://www.maxresource.com/s/Home.asp

http://www.metal-res.com/

http://www.midasresources.com.au/

http://www.moorecreek.com/index.html

http://www.niblackmining.com/s/Home.asp

http://www.alaskaexploration.com

http://www.northerndynastyminerals.com

http://www.novagold.net

http://www.pfncapital.com

http://www.akpub.com/akttt/parad.html

http://www.purenickel.com/s/Home.asp

http://www.quaterraresources.com/

http://www.rimfire.bc.ca

http://www.riotinto.com/

http://www.rubiconminerals.com

http://www.santoy.ca

http://www.tri-valleycorp.com 
Shear Minerals Ltd.

Silverado Gold Mines Ltd.

Sisyphus Consulting

St. Andrew Goldfields Ltd.

Stillwater Mining Co.

Sumitomo Metal Mining Co. Ltd

Teck Cominco Ltd.

Teryl Resources Corp.

TNR Gold Corp.

Tonogold Resources Inc.

Triex Minerals Corp.

Ucore Uranium Inc.

Usibelli Coal Mine Inc.

Western Warrior Resources Inc.

WGM Inc.

Zazu Metals Corp.

\section{Alaska Native Corporations}

Ahtna Inc.

Aleut Corp.

Arctic Slope Regional Corp.

Bering Straits Native Corp.

Bristol Bay Native Corp.

Calista Corp.

Chugach Alaska Corp.

Cook Inlet Region Inc.

Doyon Ltd.

Koniag Inc.

NANA Regional Corp.

Sealaska Corp.

\section{General}

Alaska Miners Association

Alaska Division of Geological \& Geophysical Surveys

Alaska Division of Community \& Business Development http://www.shearminerals.com

http://www.silverado.com

http://www.sisyphus-consulting.com

http://www.standrewgoldfields.com

http://www.stillwatermining.com/

http://www.sumitomocorp.co.jp/english/section_e/ shigen/index.shtml

http://www.teckcominco.com

http://www.terylresources.com

http://www.tnrgoldcorp.com

http://www.tonogold.com/s/Home.asp

http://www.triexminerals.com/s/Home.asp

http://www.ucoreuranium.com/

http://www.usibelli.com

http://www.westernwarrior.ca

http://www.wgm.com

http://www.zazumetals.com/main/

http://www.ahtna-inc.com http://www.aleutcorp.com

http://www.asrc.com

http://www.beringstraits.com

http://www.bbnc.net

http://www.calistacorp.com

http://www.chugach-ak.com

http://www.ciri.com

http://www.doyon.com

http://www.koniag.com

http://www.nana.com

http://www.sealaska.com

http://www.alaskaminers.org

http://www.dggs.dnr.state.ak.us

http://www.commerce.state.ak.us/oed/home.htm

\section{Alaska's Minerals Data and Information Rescue in Alaska (MDIRA) Project Websites}

MDIRA Portal Home Page

Alaska Geology Map Indexer

Alaska Mining Claims Information System

Alaska Resource Data Files

DGGS Publications On-Line

DNR Sites Related to Mining Applications and Forms

DOR Mining License Tax Forms

Guide to Alaska Geologic and Mineral Information

Land Records Web Application

NURE Data

On-Line Annual Payments

RASS, PLUTO Geochemistry Data

State Map Library

State Recorder's Office Search

State Uniform Commercial Code (UCC) Documents Search http://akgeology.info

http://maps.akgeology.info

http://akmining.info

http://ardf.wr.usgs.gov

http://www.dggs.dnr.state.ak.us/pubs/pubs

http://www.dnr.state.ak.us/mlw/forms

http://www.tax.alaska.gov/programs/programs/

forms/index.aspx?60610

http://www.dggs.dnr.state.ak.us/webpubs/dggs/ic/ text/ic044ed2004.PDF

http://plats.landrecords.info/index.html http://pubs.usgs.gov/of/1997/ofr-97-0492/quad_ ak/q_iditar.htm

https://www.dnr.state.ak.us/cc_payment/LAS Form.cfm

http://geopubs.wr.usgs.gov/open-file/of99-433 http://www.dnr.state.ak.us//ris/gis_maplib/maplib_start.cfm

http://www.dnr.state.ak.us/ssd/recoff/search.cfm http://www.dnr.state.ak.us/ssd/ucc/search.cfm 
APPENDIX G

U.S. Customary Units/Metric Units Conversion Chart

To convert from:

To:

Multiply by:

\begin{tabular}{|c|c|c|}
\hline \multicolumn{3}{|c|}{ Weight/Mass/Ore Content } \\
\hline ounces (avoirdupois) & grams & 28.350 \\
\hline ounces (troy) & grams & 31.1035 \\
\hline pounds & kilograms & 0.4536 \\
\hline short tons & metric tons & 0.9072 \\
\hline grams & ounces (avoirdupois) & 0.03527 \\
\hline & ounces (troy) & 0.03215 \\
\hline kilograms & pounds & 2.2046 \\
\hline metric tons & short tons & 1.1023 \\
\hline parts per million (ppm) & parts per billion (ppb) & 1,000 \\
\hline parts per million (ppm) & ounces per ton & 0.0292 \\
\hline parts per million (ppm) & grams/metric tons (tonnes) & 1.00 \\
\hline \multicolumn{3}{|c|}{ Length } \\
\hline miles & kilometers & 1.6093 \\
\hline yards & meters & 0.9144 \\
\hline \multirow[t]{3}{*}{ feet } & meters & 0.3048 \\
\hline & centimeters & 30.48 \\
\hline & millimeters & 304.80 \\
\hline \multirow[t]{2}{*}{ inches } & centimeters & 2.54 \\
\hline & millimeters & 25.4 \\
\hline kilometers & miles & 0.6214 \\
\hline \multirow[t]{2}{*}{ meters } & yards & 1.0936 \\
\hline & feet & 3.2808 \\
\hline \multirow{2}{*}{ millimeters } & feet & 0.00328 \\
\hline & inches & 0.03937 \\
\hline centimeters & inches & 0.3937 \\
\hline \multicolumn{3}{|c|}{ Area } \\
\hline square miles & square kilometers & 2.590 \\
\hline \multirow[t]{2}{*}{ acres } & square meters & $4,046.873$ \\
\hline & hectares & 0.4047 \\
\hline square yards & square meters & 0.8361 \\
\hline square feet & square meters & 0.0929 \\
\hline \multirow[t]{2}{*}{ square inches } & square centimeters & 6.4516 \\
\hline & square millimeters & 645.16 \\
\hline square kilometers & square miles & 0.3861 \\
\hline square meters & acres & \\
\hline & square feet & 10.764 \\
\hline & square yards & 1.196 \\
\hline \multirow[t]{2}{*}{ hectares } & acres & 2.471 \\
\hline & square meters & $10,000.00$ \\
\hline square centimeters & square inches & 0.155 \\
\hline square millimeters & square inches & 0.00155 \\
\hline \multicolumn{3}{|c|}{ Volume } \\
\hline cubic yards & cubic meters & 0.7646 \\
\hline cubic feet & cubic meters & 0.02832 \\
\hline cubic inches & cubic centimeter & 16.3871 \\
\hline \multirow[t]{2}{*}{ cubic meters } & cubic yards & 1.3079 \\
\hline & cubic feet & 35.3145 \\
\hline cubic centimeters & cubic inches & 0.06102 \\
\hline gallons (U.S.) & liters & 3.7854 \\
\hline liters & gallons (U.S.) & 0.2642 \\
\hline milliliters & ounces (fluid) & 0.03381 \\
\hline ounces (fluid) & milliliters & 29.5735 \\
\hline
\end{tabular}

Temperature conversions:

From degrees Fahrenheit to degrees Celsius, subtract 32 and multiply by 5/9.

From degrees Celsius to degrees Fahrenheit, multiply by 9/5 and add 32. 


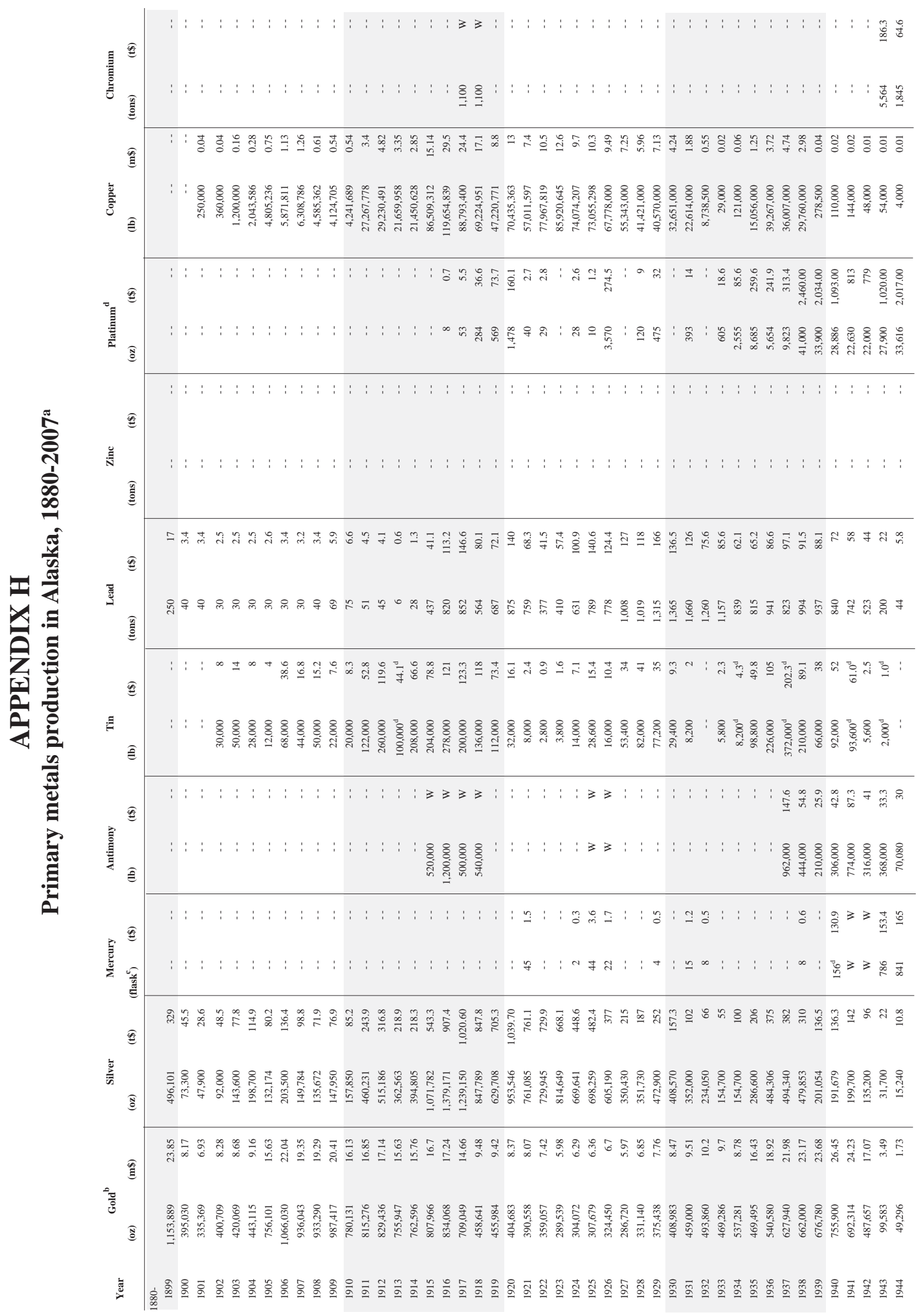




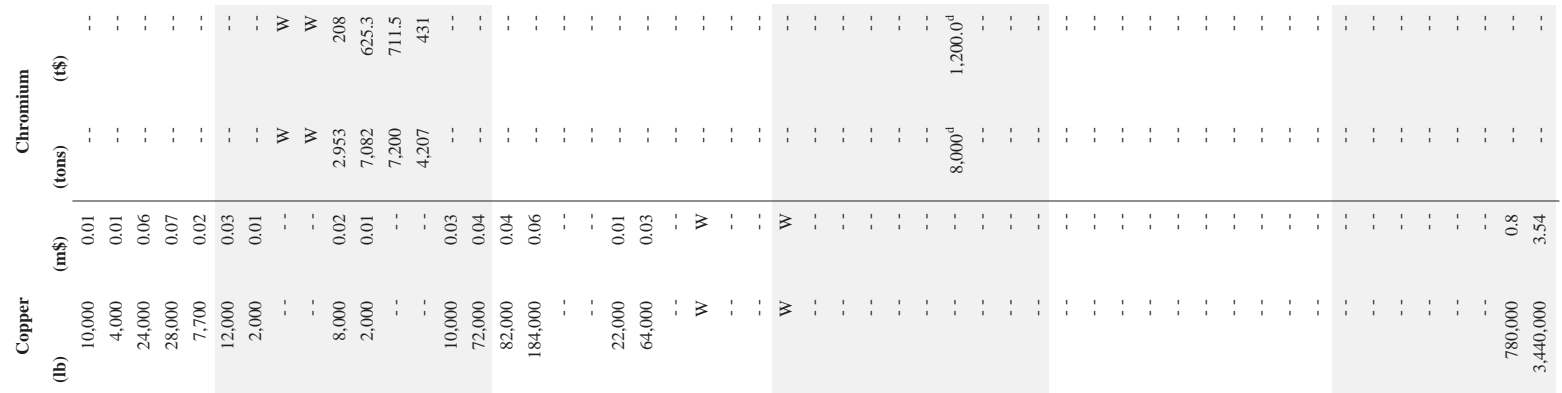

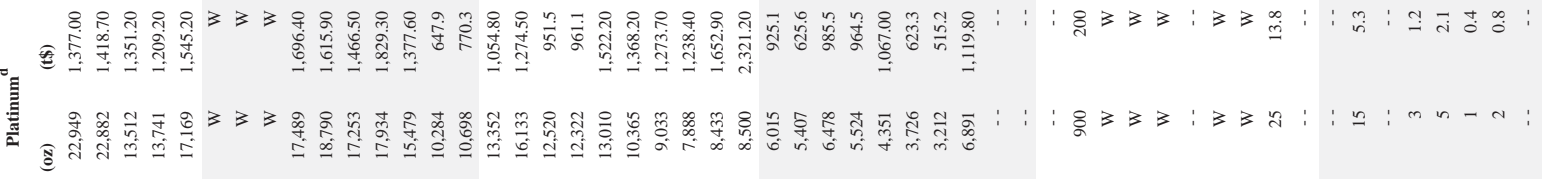

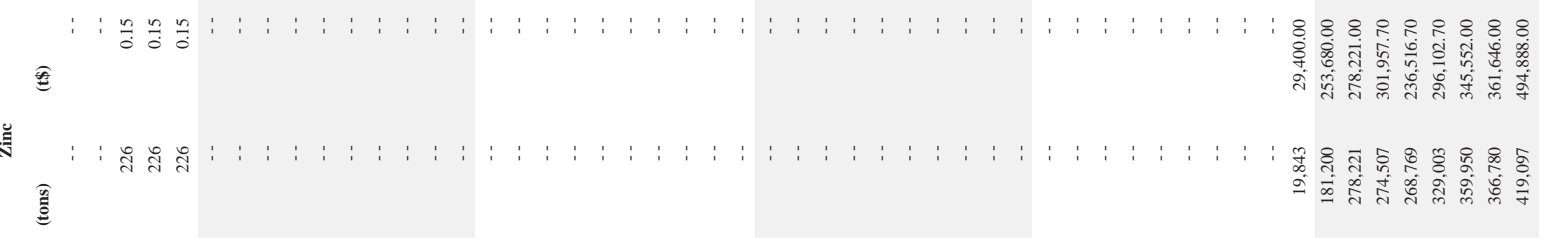

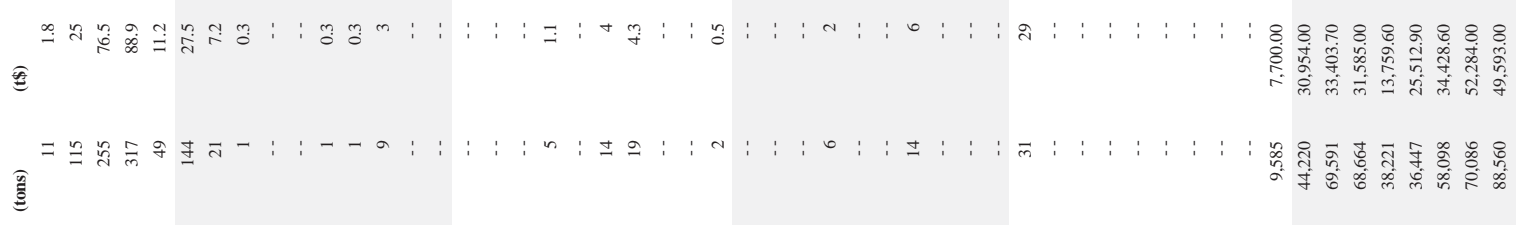

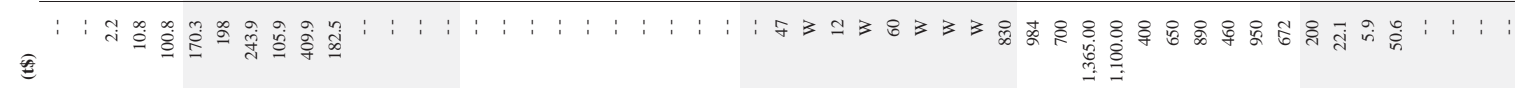

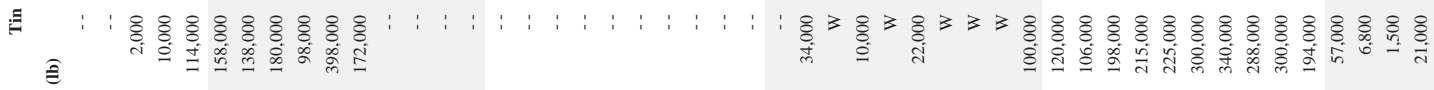

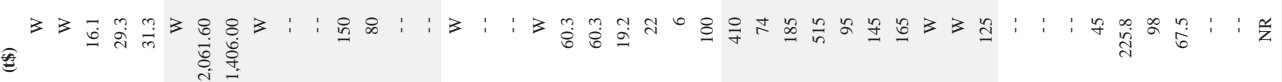

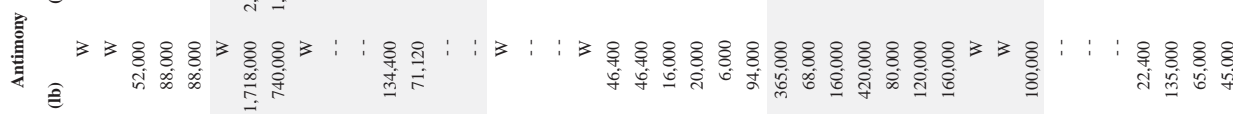

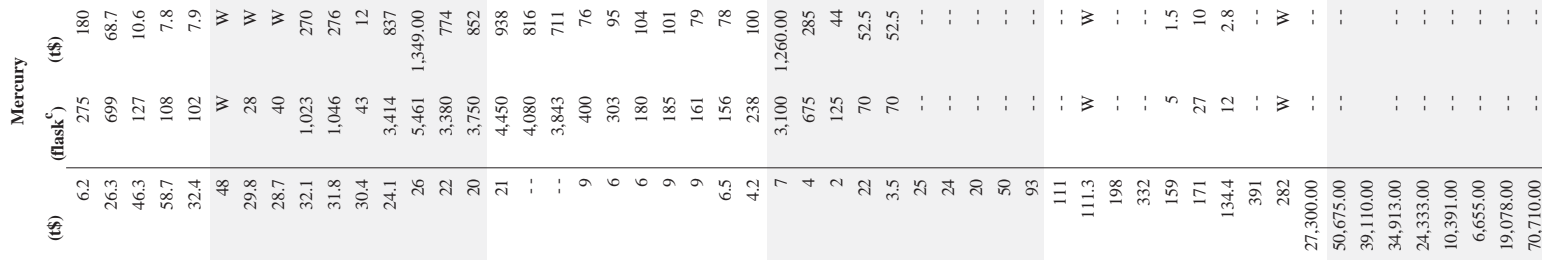

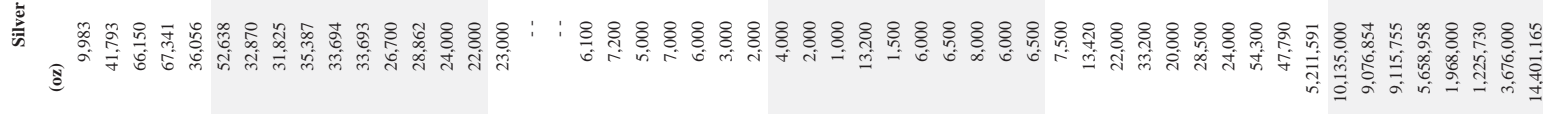

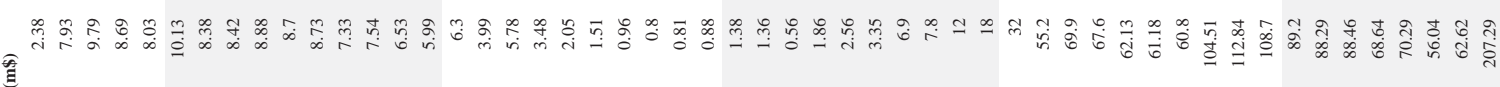

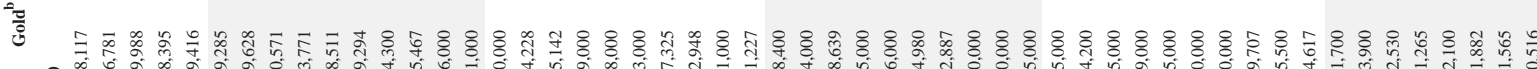

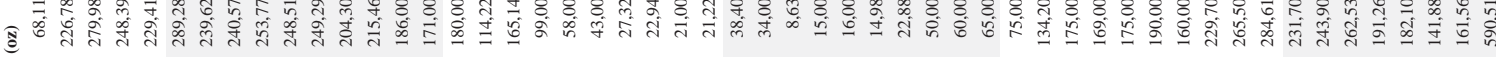

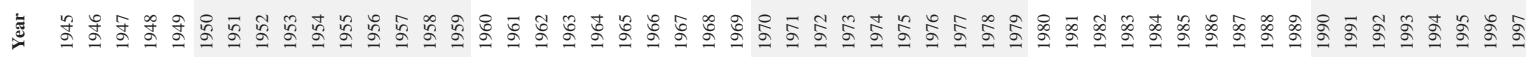




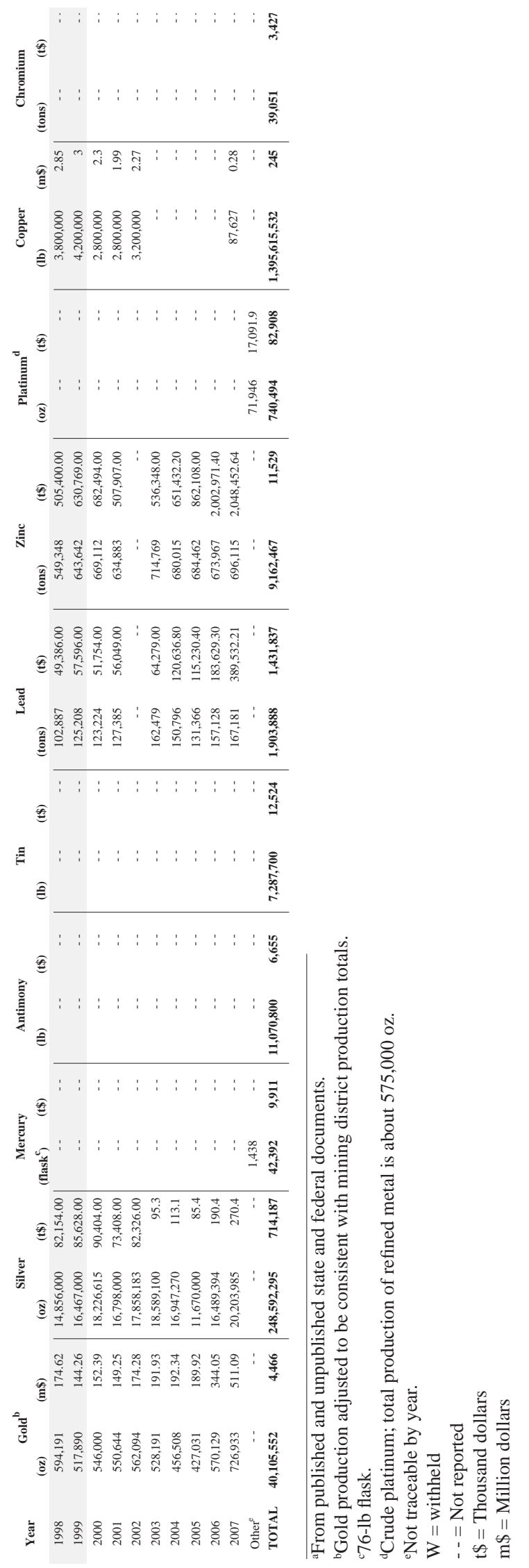


APPENDIX I

Production of industrial minerals, coal, and other commodities in Alaska, 1880-2007

\begin{tabular}{|c|c|c|c|c|c|c|c|c|c|}
\hline \multirow[b]{2}{*}{ Year } & \multicolumn{2}{|c|}{ Coal } & \multicolumn{2}{|c|}{ Sand and gravel } & \multicolumn{2}{|c|}{ Rock $^{a}$} & \multicolumn{2}{|c|}{ Barite } & \multirow{2}{*}{$\begin{array}{c}\text { Other } \\
\$\end{array}$} \\
\hline & S. tons & m\$ & s. tons & m\$ & s. tons & $\mathbf{m} \$$ & s. tons & t\$ & \\
\hline $1880-1899^{c}$ & 19,429 & 0.14 & - & - & 7,510 & 0.04 & - - & -- & - \\
\hline 1900 & 1,200 & $0.02^{\mathrm{d}}$ & - & - & 510 & 0.01 & - & -- & - - \\
\hline 1901 & 1,300 & $0.02^{\mathrm{d}}$ & - - & - - & 700 & 0.01 & - - & -- & 500 \\
\hline 1902 & $2,212^{\mathrm{d}}$ & $0.02^{\mathrm{d}}$ & - - & - - & 800 & 0.01 & - - & -- & 255 \\
\hline 1903 & 1,447 & 0.01 & - - & - - & 920 & 0.01 & - - & -- & 389 \\
\hline 1904 & 1,694 & 0.01 & - - & - - & 1,080 & 0.02 & -- & -- & 2,710 \\
\hline 1905 & 3,774 & 0.02 & - - & - & 970 & 0.02 & - & -- & 740 \\
\hline 1906 & 5,541 & 0.02 & - & - - & 2,863 & 0.03 & -- & -- & 19,965 \\
\hline 1907 & 10,139 & 0.05 & & - - & 3,899 & 0.03 & - - & - - & 54,512 \\
\hline 1908 & $3,107^{\mathrm{d}}$ & $0.01^{\mathrm{d}}$ & - - & - - & 2,176 & 0.03 & - - & - - & 81,305 \\
\hline 1909 & 2,800 & 0.02 & - - & - - & 1,400 & 0.01 & - - & - - & 86,027 \\
\hline 1910 & $1,000^{\mathrm{d}}$ & $0.01^{\mathrm{d}}$ & - - & -- & W & W & -- & -- & 96,408 \\
\hline 1911 & $900^{d}$ & $0.01^{\mathrm{d}}$ & - & - & $\mathrm{W}$ & W & - & -- & 145,739 \\
\hline 1912 & $355^{d}$ & $0.01^{\mathrm{d}}$ & - & - - & $\mathrm{W}$ & W & - & -- & 165,342 \\
\hline 1913 & 2,300 & 0.01 & -- & -- & W & W & -- & - - & 286,277 \\
\hline 1914 & 1,190 & 0.01 & - - & - & $\mathrm{W}$ & W & - & -- & 199,767 \\
\hline 1915 & 1,400 & 0.03 & -- & -- & $\mathrm{W}$ & W & - & -- & 205,061 \\
\hline 1916 & 12,676 & 0.05 & - - & - - & W & W & - - & - - & 326,731 \\
\hline 1917 & 54,275 & 0.27 & - & - & $\mathrm{W}$ & $\mathrm{W}$ & - & -- & 203,971 \\
\hline 1918 & 75,816 & 0.41 & - - & - & $\mathrm{W}$ & W & - - & -- & 171,452 \\
\hline 1919 & 60,894 & 0.35 & - - & - - & 50,014 & 0.29 & - - & -- & 214,040 \\
\hline 1920 & 61,111 & 0.36 & -- & - - & 37,044 & 0.27 & -- & -- & 372,599 \\
\hline 1921 & 76,817 & 0.49 & - & - - & 59,229 & 0.31 & - - & -- & 235,438 \\
\hline 1922 & 79,275 & 0.43 & - - & - - & 54,251 & 0.30 & - - & -- & 266,296 \\
\hline 1923 & 119,826 & 0.76 & - - & - - & 83,586 & 0.41 & - - & -- & 229,486 \\
\hline 1924 & 99,663 & 0.56 & - - & - - & 35,294 & 0.26 & - - & - - & 348,728 \\
\hline 1925 & 82,868 & 0.40 & - - & - - & 32,193 & 0.19 & - - & -- & 454,207 \\
\hline 1926 & 87,300 & 0.46 & - - & -- & 33,283 & 0.20 & - - & -- & 423,000 \\
\hline 1927 & 104,300 & 0.55 & -- & - - & 41,424 & 0.22 & - - & -- & -- \\
\hline 1928 & 126,100 & 0.66 & - - & - - & 63,347 & 0.31 & - - & -- & - \\
\hline 1929 & 100,600 & 0.53 & - & - - & 54,766 & 0.26 & - - & -- & 194,000 \\
\hline 1930 & 120,100 & 0.63 & - & - - & 66,234 & 0.33 & - - & -- & 157,300 \\
\hline 1931 & 105,900 & 0.56 & - - & - - & 59,175 & 0.29 & - - & -- & 108,000 \\
\hline 1932 & 102,700 & 0.53 & -- & - - & 54,167 & 0.27 & - - & -- & 223,400 \\
\hline 1933 & 96,200 & 0.48 & - & - - & 56,291 & 0.28 & - - & -- & - - \\
\hline 1934 & 107,500 & 0.45 & - & - - & 64,234 & 0.36 & - - & -- & 46,155 \\
\hline 1935 & 119,425 & 0.50 & -- & - - & 74,049 & 0.38 & - - & -- & 46,755 \\
\hline 1936 & 136,593 & 0.57 & -- & - - & 76,379 & 0.38 & - - & -- & 45,807 \\
\hline 1937 & 131,600 & 0.55 & - - & - - & 50,057 & 0.25 & - - & -- & 147,048 \\
\hline 1938 & 159,230 & 0.62 & - & - - & 189,090 & 0.21 & - - & -- & 125,302 \\
\hline 1939 & 143,549 & 0.60 & 42,332 & 0.02 & -- & -- & - - & -- & - - \\
\hline 1940 & 170,174 & 0.88 & 515,011 & 0.10 & -- & -- & - - & -- & - - \\
\hline 1941 & 241,250 & 0.97 & 530,997 & 0.09 & -- & - - & - - & -- & $1,367,000$ \\
\hline 1942 & 246,600 & 0.99 & W & W & -- & -- & - - & - - & $1,124,000$ \\
\hline 1943 & 289,232 & 1.84 & W & W & -- & - & - - & -- & - - \\
\hline 1944 & 352,000 & 2.37 & 712,496 & 0.50 & -- & - - & - - & -- & $2,350,309$ \\
\hline 1945 & 297,644 & 1.87 & W & W & -- & - - & - - & -- & $5,910,704$ \\
\hline 1946 & 368,000 & 2.36 & W & W & - - & - & - - & -- & $2,005,241$ \\
\hline 1947 & 361,220 & 2.55 & W & W & 219,000 & 1.00 & - - & -- & $5,927,319$ \\
\hline 1948 & 407,906 & 2.79 & W & W & 67,341 & 0.33 & - - & -- & $1,257,699$ \\
\hline 1949 & 455,000 & 3.60 & W & W & $\mathrm{W}$ & W & - - & -- & $7,181,886$ \\
\hline 1950 & 421,455 & 3.03 & $3,050,020$ & 2.38 & $\mathrm{~W}$ & W & -- & -- & $2,100,000$ \\
\hline 1951 & 494,333 & 3.77 & $6,818,000$ & 3.54 & W & W & - - & -- & $3,600,000$ \\
\hline 1952 & 648,000 & 5.77 & $6,817,800$ & 3.54 & W & W & - - & -- & $9,052,000$ \\
\hline 1953 & 861,471 & 8.45 & $7,689,014$ & 5.08 & 47,086 & 0.17 & - - & -- & $1,231,350$ \\
\hline 1954 & 666,618 & 6.44 & $6,639,638$ & 6.30 & 283,734 & 0.47 & - - & -- & $1,572,150$ \\
\hline 1955 & 639,696 & 5.76 & $9,739,214$ & 8.24 & 265,740 & 0.29 & - - & -- & $1,552,427$ \\
\hline 1956 & 697,730 & 6.37 & $9,100,000$ & 8.30 & 50,000 & 0.02 & - - & -- & $1,551,500$ \\
\hline 1957 & 842,338 & 7.30 & $6,096,000$ & 8.79 & 528,000 & 1.95 & - - & -- & $2,751,000$ \\
\hline
\end{tabular}




\begin{tabular}{|c|c|c|c|c|c|c|c|c|c|}
\hline \multirow[b]{2}{*}{ Year } & \multicolumn{2}{|c|}{ Coal } & \multicolumn{2}{|c|}{ Sand and gravel } & \multicolumn{2}{|c|}{ Rock $^{\mathbf{a}}$} & \multicolumn{2}{|c|}{ Barite } & \multirow{2}{*}{$\begin{array}{c}\text { Other }^{b} \\
\$\end{array}$} \\
\hline & s. tons & $\mathbf{m} \$$ & s. tons & m\$ & s. tons & $\mathbf{m} \$$ & s. tons & t\$ & \\
\hline 1958 & 759,000 & 6.93 & $4,255,000$ & 3.87 & 615,000 & 2.07 & -- & -- & 695,000 \\
\hline 1959 & 602,000 & 5.88 & $5,600,000$ & 5.10 & 54,000 & 0.20 & -- & -- & $1,338,000$ \\
\hline 1960 & $669,000^{d}$ & $5.95^{d}$ & $5,892,000$ & 5.35 & 80,000 & 0.30 & -- & -- & 975,000 \\
\hline 1961 & $650,000^{d}$ & $5.87^{d}$ & $5,241,000$ & 4.19 & -- & - & - & - & - \\
\hline 1962 & $675,000^{d}$ & $6.41^{\mathrm{d}}$ & $5,731,000$ & 5.36 & -- & -- & -- & - & - \\
\hline 1963 & 853,000 & 5.91 & $16,926,000$ & 22.01 & W & W & W & W & $2,589,000$ \\
\hline 1964 & 745,000 & 5.01 & $26,089,000$ & 18.49 & W & W & W & W & $4,912,000$ \\
\hline 1965 & $860,000^{d}$ & $5.88^{d}$ & $29,959,000$ & 33.93 & W & W & W & W & $5,296,000$ \\
\hline 1966 & 927,000 & 6.95 & $17,457,000$ & 21.79 & W & W & 44,000 & 350 & $6,167,000$ \\
\hline 1967 & 930,000 & 7.18 & $22,300,000$ & 26.25 & W & W & W & W & $4,924,000$ \\
\hline 1968 & $812,000^{d}$ & $5.03^{d}$ & $17,515,000$ & 20.73 & W & W & 91,000 & W & $4,117,000$ \\
\hline 1969 & $728,000^{d}$ & $4.65^{d}$ & $16,205,000$ & 18.62 & $1,954,000$ & 3.90 & 90,000 & 850 & $5,163,000$ \\
\hline 1970 & $786,000^{d}$ & $5.28^{d}$ & $20,375,000^{d}$ & $26.07^{d}$ & $6,470,000$ & 10.01 & 134,000 & $1,875.00$ & $7,994,000$ \\
\hline 1971 & $748,000^{d}$ & $5.05^{d}$ & $26,391,000$ & 41.99 & $2,658,000$ & 5.07 & 102,000 & $1,075.00$ & - \\
\hline 1972 & $720,000^{d}$ & $6.26^{\mathrm{d}}$ & $14,187,000$ & 15.21 & 652,000 & 3.01 & W & W & - \\
\hline 1973 & $700,000^{d}$ & $6.23^{\mathrm{d}}$ & $19,350,000$ & 19.01 & $5,967,000$ & 12.00 & 112,000 & $1,792.00$ & $12,846,000$ \\
\hline 1974 & 700,000 & 7.34 & $118,740,000^{\mathrm{d}}$ & $240.94^{\mathrm{d}}$ & $5,484,000$ & 12.95 & 110,000 & $1,895.00$ & $14,495,000$ \\
\hline 1975 & 766,000 & 7.81 & $48,145,000$ & 95.78 & $8,877,000$ & 26.65 & 2,000 & 30 & $12,731,000$ \\
\hline 1976 & 705,000 & 8.00 & $74,208,000^{\mathrm{d}}$ & $204.73^{\mathrm{d}}$ & $6,727,000$ & 20.09 & $\mathrm{~W}$ & W & $14,019,000$ \\
\hline 1977 & $780,000^{d}$ & $12.00^{\mathrm{d}}$ & $66,126,000$ & 134.25 & $4,008,000$ & 17.47 & - & - & $14,486,000$ \\
\hline 1978 & 750,000 & 15.00 & $51,100,000$ & 122.00 & $3,437,000$ & 14.65 & 22,000 & 750 & - \\
\hline 1979 & 750,000 & 16.00 & $50,900,000$ & 104.90 & $3,650,000$ & 15.45 & 20,000 & 800 & 930,000 \\
\hline 1980 & 800,000 & 16.00 & $40,000,000$ & 86.00 & $3,700,000$ & 15.40 & 50,000 & $2,000.00$ & 97,500 \\
\hline 1981 & 800,000 & 17.60 & $46,000,000$ & 88.20 & $4,200,000$ & 19.30 & - - & - & 256,000 \\
\hline 1982 & 830,000 & 18.00 & $45,000,000$ & 91.00 & $3,400,000$ & 15.60 & -- & -- & 150,000 \\
\hline 1983 & 830,000 & 18.00 & $50,000,000$ & 105.00 & $5,270,000$ & 25.00 & -- & -- & 242,000 \\
\hline 1984 & 849,161 & 23.75 & $27,000,000$ & 95.00 & $2,700,000$ & 16.00 & -- & -- & 875,875 \\
\hline 1985 & $1,370,000$ & 39.73 & $28,184,080$ & 112.06 & $2,500,000$ & 12.00 & -- & -- & 559,000 \\
\hline 1986 & $1,492,707$ & 40.10 & $20,873,110$ & 75.76 & $4,200,000$ & 20.32 & -- & -- & 384,800 \\
\hline 1987 & $1,508,927$ & 42.35 & $16,696,374$ & 42.66 & $1,805,000$ & 11.62 & -- & - & 388,400 \\
\hline 1988 & $1,551,162$ & 44.30 & $17,264,500$ & 48.75 & $3,600,000$ & 24.65 & -- & -- & 389,000 \\
\hline 1989 & $1,452,353$ & 41.46 & $14,418,000$ & 39.88 & $2,914,000$ & 20.34 & -- & -- & $1,492,000$ \\
\hline 1990 & $1,576,000$ & 44.99 & $15,013,500$ & 40.82 & $3,200,000$ & 22.1 & -- & -- & 400,000 \\
\hline 1991 & $1,540,000$ & 39.00 & $14,160,011$ & 45.45 & $3,000,000$ & 22.5 & - & - & 462,000 \\
\hline 1992 & $1,531,800$ & 38.30 & $14,599,746$ & 42.2 & $2,900,000$ & 22.97 & -- & -- & 430,000 \\
\hline 1993 & $1,586,545$ & 38.10 & $13,162,402$ & 40.64 & $3,561,324$ & 26.21 & -- & - & 465,000 \\
\hline 1994 & $1,490,000$ & 36.75 & $13,518,321$ & 40.95 & $3,843,953$ & 27.04 & -- & - & 459,500 \\
\hline 1995 & $1,640,000$ & 41.30 & $9,847,550$ & 30.89 & $2,811,152$ & 22.13 & -- & -- & 182,500 \\
\hline 1996 & $1,481,000$ & 38.00 & $9,890,463$ & 32.2 & $3,000,045$ & 23.56 & -- & - & 200,000 \\
\hline 1997 & $1,446,000$ & 38.05 & $13,800,000$ & 51.91 & $3,200,000$ & 20.00 & -- & -- & 217,000 \\
\hline 1998 & $1,339,000$ & 35.23 & $12,363,450$ & 57.28 & $1,636,200$ & 14.04 & -- & -- & 215,000 \\
\hline 1999 & $1,560,000$ & 41.05 & $10,600,000$ & 52.42 & $1,640,000$ & 18.01 & -- & -- & - \\
\hline 2000 & $1,473,355$ & 38.77 & $10,600,000$ & 49.86 & $5,200,000$ & 36.59 & -- & -- & - \\
\hline 2001 & $1,537,000$ & 48.11 & $10,360,000$ & 55.22 & $3,091,000$ & 27.18 & -- & -- & - \\
\hline 2002 & $1,158,000$ & 37.40 & $22,412,000$ & 120.7 & $3,152,000$ & 31.44 & -- & -- & - \\
\hline 2003 & $1,088,000$ & 38.08 & $11,868,001$ & 64.14 & 861,382 & 10.41 & -- & - & 175,000 \\
\hline 2004 & $1,450,000$ & 50.75 & 19,576,092 & 101.51 & $7,312,050$ & 106.21 & -- & -- & $2,732,554$ \\
\hline 2005 & $1,402,174$ & 49.08 & $16,620,009$ & 76.54 & $2,803,172$ & 22.55 & -- & -- & 809,642 \\
\hline 2006 & $1,397,500$ & 48.91 & $13,953,465$ & 63.35 & $2,369,738$ & 23.85 & -- & -- & $1,057,500$ \\
\hline 2007 & $1,273,004$ & 44.56 & $14,163,676$ & 76.12 & $2,211,954$ & 25.51 & & & 7,500 \\
\hline Other $^{\mathrm{d}}$ & -- & -- & -- & - - & $2,300,000^{\mathrm{e}}$ & W & 79,000 & W & - \\
\hline TOTAL & $64,953,013$ & 288 & $1,272,387,242$ & 3,064 & $145,734,296$ & 837 & 856,000 & 11,417 & $182,544,068$ \\
\hline
\end{tabular}

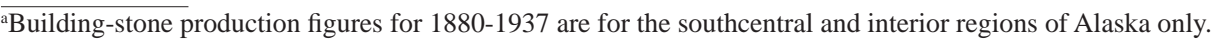

bIncludes 2.4 million lb U3O8 (1955-71); 505,000 tons gypsum (1905-26); 286,000 lb WO3 (intermittently 1916-80); 94,000 lb asbestos (194244); 540,000 lb graphite (1917-18 and 1942-50); and undistributed amounts of zinc, jade, peat, clay, soapstone, miscellaneous gemstones, and other commodities (1880-1993).

'Production not traceable by year.

${ }^{d}$ When state (territorial) and federal figures differ significantly, state figures are used. Figures for sand and gravel production in 1974 show state estimates (118,740,000 s. tons; $240.94 \mathrm{~m} \$$ ) and federal (42,614,000 s. tons; $88.96 \mathrm{~m} \$)$. The federal estimate was not added to total production.

${ }^{\mathrm{e}}$ Marble quarried on Prince of Wales Island, southeastern Alaska (1900-41).

${ }^{\mathrm{f}}$ Rounded to nearest 1,000 ton.

m\$ = Million dollarst\$ = Thousand dollars- - = Not reported.

$\mathrm{W}=$ withheld. 
Districts producing more than $5,000,000$ ounces of gold

Districts producing more than

$1,000,000$ ounces of gold
Total gold production in Alaska by mining district 1880-2007

$\begin{array}{ll}5 & \text { Colville district } \\ 6 & \text { Canning district } \\ 7 & \text { Sheenjek district }\end{array}$

Sheenjek district
Chandalar district

Koyukuk district
Shungnak district

Kiana \& Selawik districts

Fairhaven district (Candle subdistrict)

Serpentine district

Port Clarence district
Kougarok district

17 Nome (Cape Nome) district

$\begin{array}{ll}18 & \text { Council district } \\ 19 & \text { Koyuk district }\end{array}$

Koyuk district
Hughes district

Hughes district
Kaiyuh district

$\begin{array}{ll} & \text { Kaiyuh district } \\ & \text { Anvik district } \\ & \end{array}$

Marshall district
Bethel district

Goodnews Bay distric

$\begin{array}{ll}26 & \text { Aniak district } \\ \text { Iditarod distric } & \end{array}$

28 McGrath district

$\begin{array}{ll}29 & \text { Innoko district } \\ 30 & \text { Ruby district }\end{array}$

31 Kantishna district

Hot Springs distric
Melozitna district

Rampart district
Tolovana district

36 Yukon Flats distric

Black district

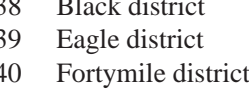

41 Chisana distriis

43 Goodpaster district

44 Fairbanks diststict

Richardson subdistrict of Fairbanks district

$\begin{array}{lll}47 & \text { Delta River district } \\ 48 & \text { Chistóchlina district }\end{array}$

49 , Valdez Creek distric
50 ' Yentna district

50 Yenthaa distrtict
51 , Redoubt district

、 Bristol- Bay Region

Kodiak district (53b)-Alaskà Peninsula Region (53a)

Homer district
55 Hope, \& Seward dis

Hope \& Seward dist
Anchorage district ${ }^{d}$

$\begin{array}{ll}57 & \text { Willow Creek district } \\ 58 & \text { Prince William Sound district }\end{array}$

Nelchina districtt
Nizina district

1 Yakataga districic

Juneau (64a) \& Ad
Chichagof district

$\begin{array}{ll}6 & \text { Petersburg district } \\ 67 & \text { Kwrreanof district }\end{array}$

Hyder district

Ketchikan district
Bering Sea Region

Aleutian Illands Region
Unknown (undsistributed)
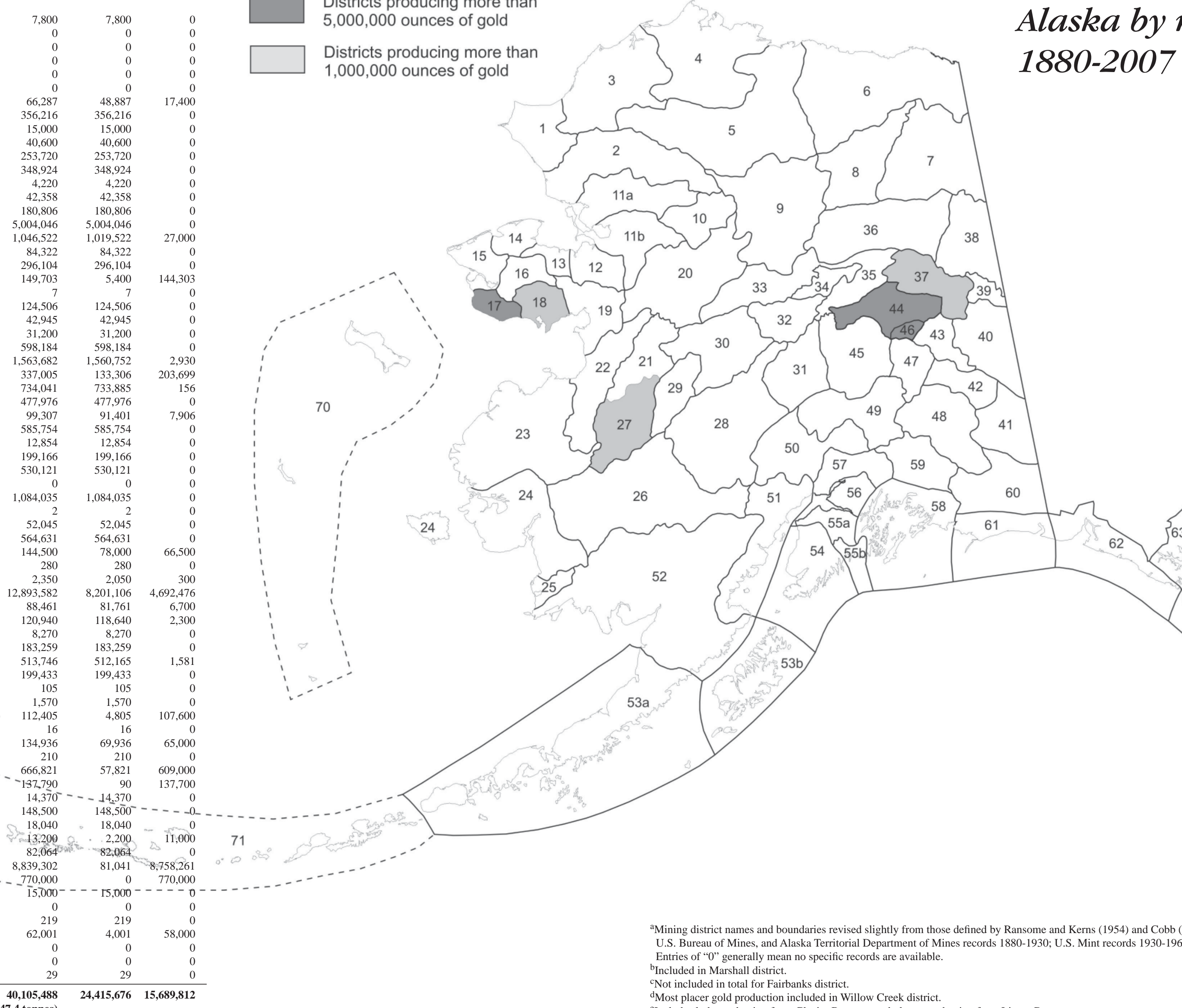

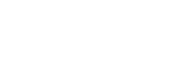




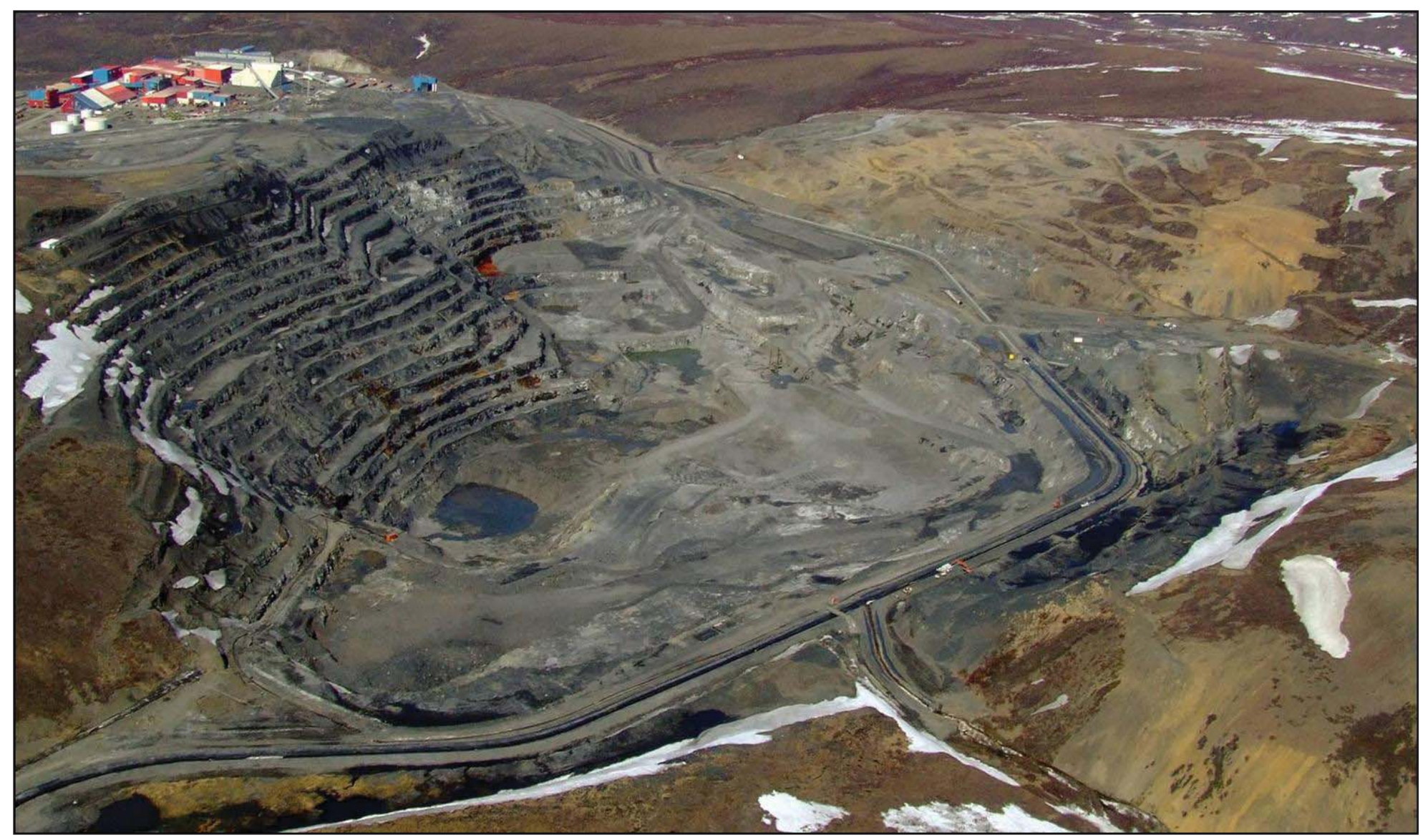

Above. Aerial view of the main Red Dog Mine on left and Aqqaluk deposit on upper right. Teck Cominco conducted in-fill drilling at Aqqaluk during 2007, with plans to begin stripping waste by 2010. Photo provided by Teck Cominco Alaska.

Right. Gold bar produced at the Pogo Mine. Photo courtesy of Teck Cominco Ltd.

Bottom right. Pouring concrete footings for mill facilities at NovaGold Resources Inc.'s Rock Creek gold project near Nome. Photo provided by NovaGold Resources Inc.

Below. Full Metal Minerals Ltd. geologist Cullan Lester holding massive sulfide drilled at Full Metal's 40 Mile project. Photo provided by Full Metal Minerals Ltd.

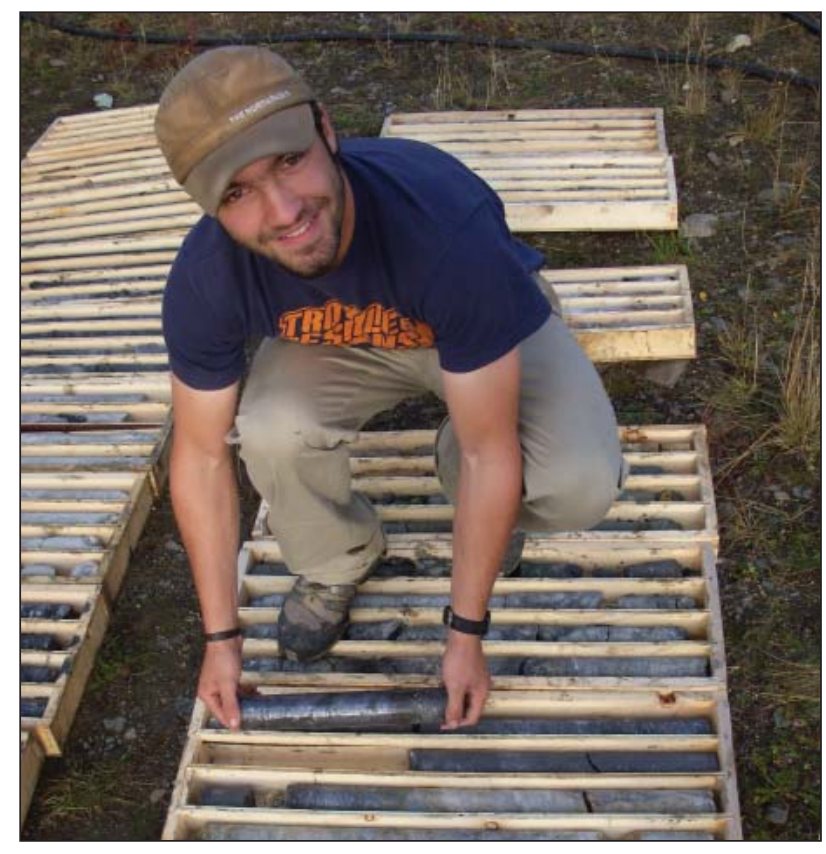

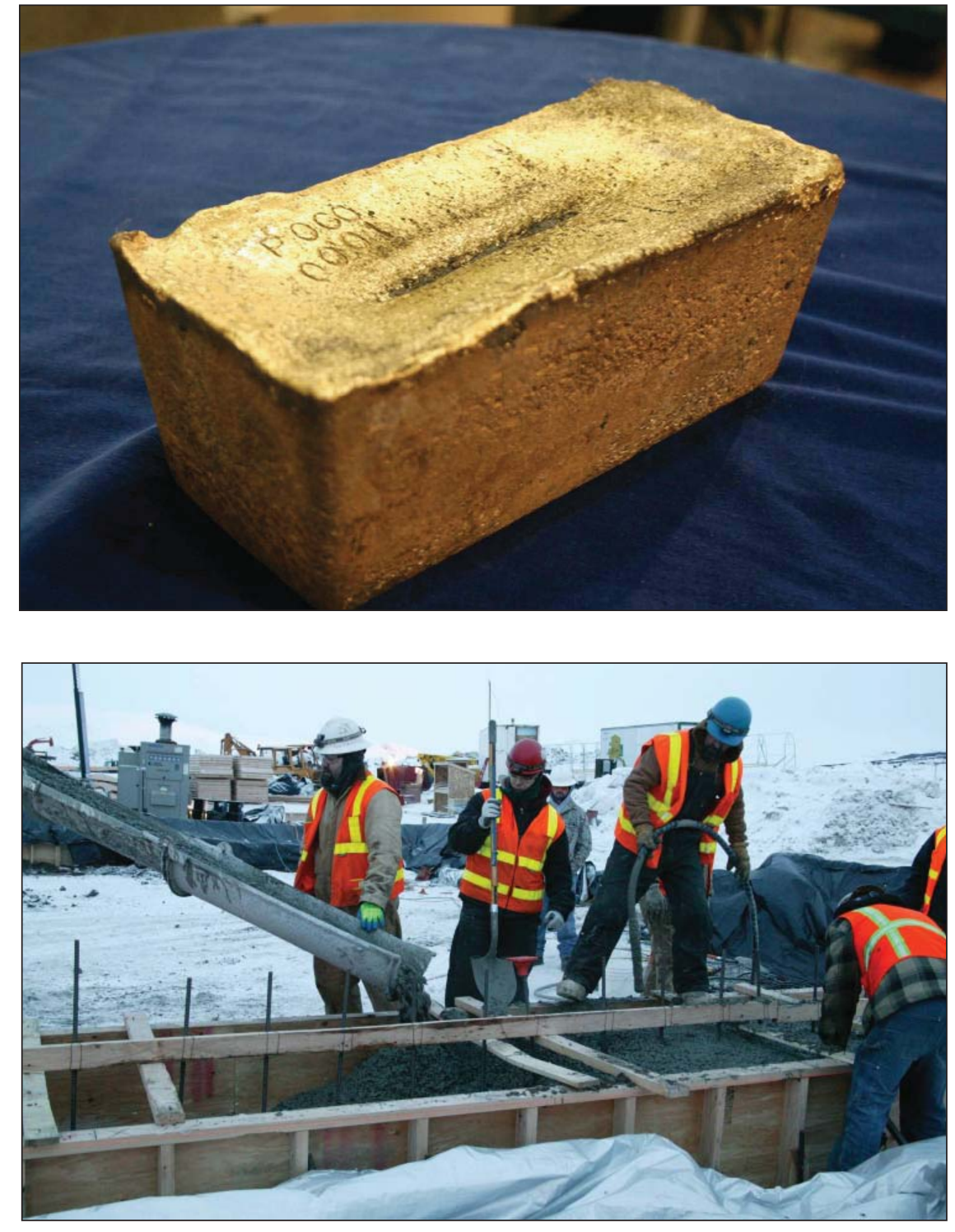

